
$62 \times 2$ und 
A. L. R:ELANDER

From the Litrary of

b. W. Johison 























Papers on Dipteras
Ent.

Kansas University Ouarterly.

VoL. II.

$\cdot$ JULi, I 893.

No. I.

\section{Rerision of the Genera Dolichopus and Hygroceleuthus.}

WY J. Me MlDRICH.

(With Plate 1.)

The two genera discussed in the present paper are readily separated from all other North American Dolichopoliclix by the presence of two distinctive characters, - the hind metatarsus with one or more bristles above, and the first antennal joint hairy abore. In order to distinguish them from some related foreign genera, it is necessary to ald only one other peculiarity, - the antennal arista is always bare or pubescent, never plumose.

DOLICHOPUS Latreille.

Of the group so limited, nearly all the numerous species belong to Dolichopus; under the head of Hygrocleuthus will be found a statement of the characters belonging especially to the latter genus; see also Loew's Monograph.

The following descriptions bring up the total number of North American species of Dolichopus to eighty-one, of which only fortyseven are found in Loew's Monograph. Of the remainder, five were described later by Loew in his seventh Century; Osten Sacken described three in his Westem Diptera and one (mlosota) in Biologia Centrali-Americana; Diptera I, 213: Wheeler published four (incongruus, flagellitenens. henshawi, germanus) in Psyche. May, I8go, p. 337 ; and twenty-one are described in the following pages. The bibliographical references omitted here are found in Osten Sacken's catalogue.

The acquisition of such a large number of species since Loew's time has only served to emphasize the correctness of his riews on the geographical distribution of the genus. It belongs distinctly to the

(1) KAN, एXIY. QTA[r. VOI, 11, No. 1, JULLY, 1893. 
north temperate zone, and seems scarcely to reach the souther border of the United States; the only species of true Dolichopus nnown by me to occur farther south are mosota in North Sonora, ne ar the Arizona line, and an undescribed species, mentioned by Osten a acken in the sam connection, from Durango; but the latter is known to be Alpine ( 8 roo ft.) I have examined large collections of IIest IIdian and South American material without finding the genus.

I am indebted to the University of Kansas for the opportunit, to work 1 p her excellent collection (indicated in the article by U. K.); to Dr. Williston for books and other assistance; to C. W. Johnson, D. W. ('oquillett, and others for material contributed.

\section{Table of Species of Iolichopus.}

SECTION A: IEMORA CHIEFLT BLACK.

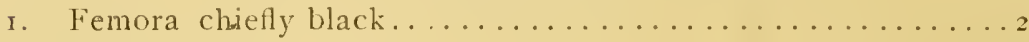

Femora yellow...................... 6

2. Cilia of inferior orbit black ................ $\ldots \ldots$

Cilia of inferior orbit pale.....................

3. IFings deeply infuscated; four anterior tibix yellow.......

johnsoni, n. sp.

Wings hyaline or nearly so.................

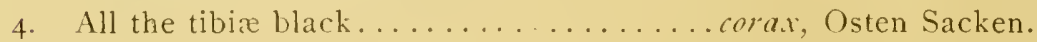

Four anterior tibia yellow . . . . . . . . . . . . . . .

5. Third joint of antennx large; tegular cilia usually pale.... laticornis, Loew.

Third joint of antennæe as usual, tegular cilia black.......6

6. Hind tibia yellow at base.............. gratus, Loew. Hind tibia wholly black............... calcaratus, n. sp.

7. Middle tibia black . . . . . . . . . . . . . . . . . . . . . . . . . . .

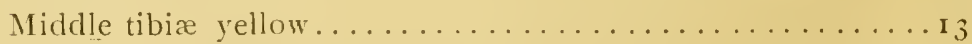

8. Apical third of femora yellow.............tetricus, Loew.

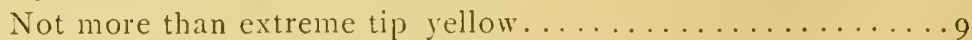

9. Hind femora of male ciliated .................. ro

Hind femora of male not ciliated............... I I

ro. Cilia of femora long, face of male narrow......detersus, Loew. Cilia not loag, face of male wide...........kansensis, n. sp.

11. Legs wholly black..............myosota, Osten Sacken.

Fore tibia brownish-yellow . . . . . . . . . . . . . I 2

12. Lamellæ of hypopygium pointed ........... acuminatus, Loew. Lamellæ of hypopygium rounded............. oratus, Loew.

13. First joint of hind tarsi with numerous bristles.... setifer, Loew. First joint of hind tarsi with few bristles............ I 4

14. Hind femora of male not ciliated. third and fourth veins of wing unusually convergent ........... coneergens, n. sp. 
Hind femora of male ciliated ................. 5 5

15. The black color at tip of hind tibic rather extencled and not sharply linited................... albiciliatus, Loew.

The black color but little extended and sharply limited.... ...santhocnemus, Loew.

SECTION B : FEMIORA YELLOW.

Group $I$ : cilia of inferior orlit black.

16. Cilia of inferior orbit black ................ I 7

Cilia of inferior orbit pale............... I

I7. Fore coxæ blackish............... pachycnemus, Loew.

Fore coxa yellow ... . . . . . . . . . . . . . . . I 8

I8. Cilia of tegula pale ...............ncongrums, Wheeler.

Cilia of tegula black . . . . . . . . . . . . . . . I 9

I9. First two joints of antennæe yellow........... dorycerts, Loew Whole antennæ black............... brevipenmis, Meigen.

Group 2: cilia of inferior orbit pale.

Sub-group a: cilia of tegulæe pale.

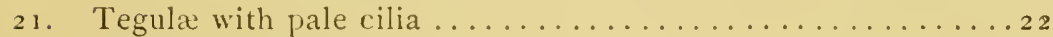

Tegula with black cilia ...................... $3^{6}$

22. Antennæ black, first joint sometimes partly yellowish-red...23

Antennæ chiefly or wholly yellowish-red............

23. Fore coxæ dark at base, beyond the middle. longimanus, Loew.

Fore coxie pale........................... 4

24. Tip of hind tibia distinctly black .............. 25

Tip of hind tibia not or but slightly infuscated......... 7

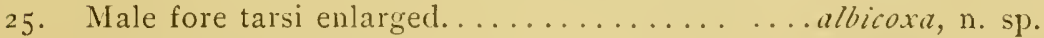

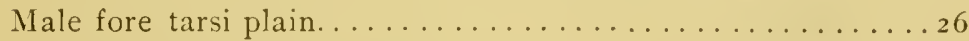

26. Fore tarsi ferruginous-brownish only........ breilimamm, Loew.

Fore tarsi blackened from tip of first joint........ socius, Loew.

27. Hind tarsi entirely black ................... 8

Hind tarsi to a considerable extent pale................ 32

28 . Hind femora of male not ciliated .............ulus, Loew.

Hind femora of male ciliated . . . . . . . . . . . . . 29

29. The enlarged last joint of the male fore tarsi on the outside

with a white reflection.............palcstricus, Loew.

The same without a white retlection ................ 30

30. Hind femora of male very densely ciliated.... splendidus, Loew.

Hind femora of the male sparsely ciliated . . . . . . . . . I

3r. Hind tibize not infuscated at the tip ; fourth joint of male fore tarsi somewhat broader than the preceding...... 
Hind tibia somewhat infuscated at the tip; fourth joint of male fore tarsi not broader than the preceding .subciliatus, Loew.

32. Only the last joint of the male fore tarsi enlarged batillifer, Low The last two joints enlarged..................... 33

The last three joints enlarged ; third and fuurth white, fifth

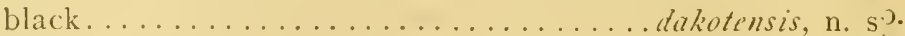

33. Hind femora of male ciliated ... . . . . . . cudactylus, Loew. Hind femora of male not ciliated........... tonsus, Loew.

34. Last joint of male fore tarsi enlarged............tener, Loew.

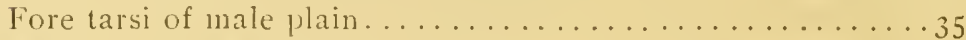

35. Wings hyaline with a grayish tinge.......... . turabilis, Loew. Wings hyaline with a yellowish tinge........ luteipennis, Loew.

Sub-group b: tegulæ witl black cilia.

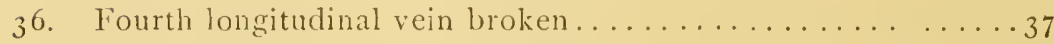

Fourth longitudinal rein not broken ............. 43

37. Dorsum of thorax yellow pollinose, opaque... bifiactus, l,oew. Dorsum of thorax geren, more or less shining .............. 8

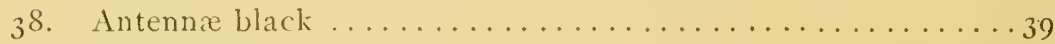

Antenna yellowish-red...................... . . .

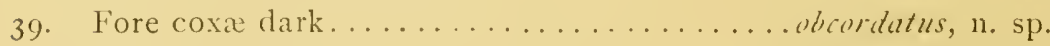
Fore coxa yellow .................. mamifer, Loew.

40. Hind tarsi and tips of of tibix black.......... reflectus, n. sp. Hind tibia and basis of hind tarsi yellow............ I

$4 \mathrm{r}$. Tarsi of the male plain ............... rittatus, Loew.

Tarsi of male fringed with black at tij ............ 42

42. Hind femora of male ciliated; wings normal....cuprinus, Loew. Hind femora not ciliated; wings narrowed at base....... longipennis, Loew.

43. Arista of male antenna enlarged at tip; middle tibixe in both sexes with black tip.............hastatus, Loew. Arista plain ........................... . 44

44. Middle tarsi entirely black: in the male the first joint laterally feathered................. plumipes, Scopoli.

Middle tarsi more or less yellow at base, not feathered.....45

45. Hind tibice distinctly black at tip................ . 6

Hind tibia not or scarcely infuscated at tip . . . . . . . . . . 58

46. Antenna black, first joint sometimes yellow below........49 First joint entirely yellow . . . . . . . . . . . . . . . . . . . .

47 . Antennce yellow, tip of third joint blackened. . . . . . . . . 48 Third joint and part of second black... flagellitenens, Wheeler. 48. Male fore tibic incrassated at tip..........henshawi, Wheeler. 
Male fore tibiæ not incrassated at tip......... . igigilans, n. sp.

49. Middle tarsi of nale with long hairs abore on first joint....

Middle tarsi plain ....................... 50

50. Fore coxa pale.......................... 5 I

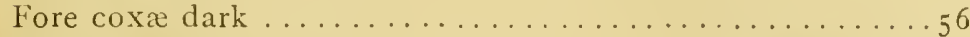

5I. Blackish-bronze specics; siєe $3 \mathrm{~mm} \ldots \ldots \ldots \ldots$ brunneus, n. sp.

More or less green species, much larger. . . . . . . . . . $5^{2}$

52. Fore tarsi of male plain.................. 53

Fore tarsi of male enlarged ........... discifer, Stannius.

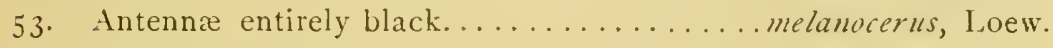

First joint reddish below. . . . . . . . . . . . . . . 54

54. Length about $6 \mathrm{~mm}$.; hind tibia of male with longer bristles

than usual......................... setosus, Loew.

Length about $+m m$; hind tibie as usual. . . . . . . . . 55

55. Basal half of fore coxæ with minute whitish hairs........

platyprosopus, Loew.

Basal half of fore coxa with minute black hairs. incisuralis, Loew.

56. Fore tarsi of male plain.............. prastus, Loew.

Fore tarsi of male enlarged . . . . . . . . . . . . 57

57. First three joints of male fore tarsi with black tips.......

pollex, Osten Sacken.

First three joints of male fore tarsi wholly yellow obcordatus, n.sp.

58. Hind tarsi entirely black ... . . . . . . . . . . . 59

Hind tarsi considerably pale at base..............65

59. Third joint of antenna almost entirely yellow....gracilis, n. sp.

Third joint largely or wholly black ..............6o

6o. Third joint of antennæ large and pointed; wings narrowed

at base.................... angustatus, n. sp.

Third joint and wings as usual . . . . . . . . . . . . 6

6r. Male fore tarsi enlarged..................62

Male fore tarsi not enlarged..................... 64

62. Anal angle of wing in male with two lobes...... lobatus, Loew.

Anal angle as usual ....................... 63

63. First joint of antenna chiefly or wholly black . discifer, Stannius. First joint yellow, the following black ........... agilis, n. sp.

Whole antenna yellow except apical half of third joint...

pugil, Loew.

64. Lamellæ of hypopygium with numerous long, black bristles

Lamella of hypopygium with the usual short, curved bris-

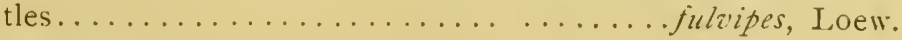

65 Third joint of antennit black.................66 
Third joint of antenna largely red............... $7^{2}$

66. Last two joints of male fore tarsi laterally feathered......

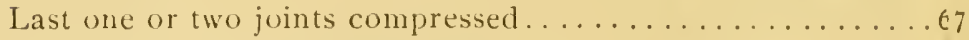

67 Lamella of hypopygium bilobed ...............68

Lamella simple......................... . 60

68. Antennie black, first joint sometimes reddish below......

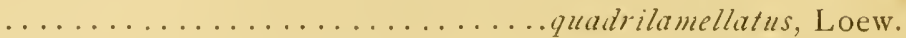

Antenna red, third joint black ............duplicatus, n. sp.

69. Hind femora of male ciliated.......... inaliculatus, Thomson.

Hind femora of male not ciliated. .............. 70

70. Costa of male enlarged. . . . . . . . . . . . . .

Costa of male not perceptibly enlarged........ ioguilletti, n. sp.

7 r. Last joint of the male fore tarsi as long as the two preced-

$\operatorname{ing} \ldots \ldots \ldots \ldots \ldots \ldots \ldots \ldots \ldots \ldots \ldots \ldots \ldots \ldots$ plumos, n. sp.

Last joint of the male fore tarsi nearly as long as the three

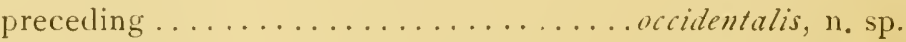

72 . Humeral callosity of the same color as the dorsum of the thorax ......................... . .

Humeral callosity yellowish $\ldots \ldots \ldots \ldots \ldots \ldots \ldots \ldots \ldots \ldots$

73. Fore tarsi of the male plain ............. siupularis, Loew.

Fore tarsi enlarged................. funditur, Loew.

$7+$ Fore tarsi of the male plain................. 75

Fore tarsi of the male not plain ................ 77

75. Male costa very distinctly thickened.......... rittatus, Loew.

Male costa not or scarcely thickened............. 76

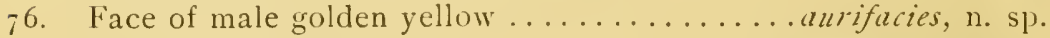

Face of male white............... sermanus, Wheeler.

77. Second joint of male fore tarsi longer than the first. grandis, n. sp. Second joint shorter than the first $\ldots \ldots \ldots \ldots \ldots \ldots \ldots$

78. Last joint of male fore tarsi greatly enlarged, bilobed...... . 79

Last joint not greatly enlarged.................. . . .

79. Both lobes of last joint of male fore tarsi tipped with silvery

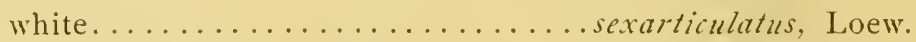

Only the upper lobe so tipped............ willistonii, n. sp.

8o. Hind femora of male not ciliated................ s $_{\text {I }}$

Hind femora of male ciliated . . . . . . . . . . . . . $8_{3}$

81. Third and fourth joints of male fore tarsi fringed with black

above........................ 82

Third and fourth joints not so fringed; fifth joint black, a

little compressed ................terminalis, Loew.

82. Wings of male narrowed at base.......... longipennis, Loew.

Wings of male not narrowed .............. sarotes, Loew. 
33. Last joint of male fore tarsi enlarged......... ruficornis, Loew.

Last joint not enlarged; third and fourth joints fringed with

black above................... cupinus, Wiedemann.

\section{IJolichopus johnsoni, n. sp.}

Jegs and cilia of orbit and tegule black; wings infuscated.

Face narrow, with yellowish pollen; front green. Antennæe black, third joint rounded. Thorax shining green, rather dark: pleuræ, black. Tegule and halteres yellow. Abdomen dark blue-green, posterior margins of segments blackish. Lamella of hypopygium white with brown border and bristles. Coxæ black, yellow tipped, the front ones white dusted. Femora black, knees yellow; anterior tibix yellow, hind ones black. Anterior tarsi yellow, infuscated toward the tip; hind ones black. Fore tarsi simple. Hind tibiæ a little thickened. Wings narrowed toward the base, the outer two-thirds strongly infuscated, the smokiness fading away gradually toward the root.

Length, $3.2 \mathrm{~mm}$; of wing, $3 \mathrm{~mm}$.

One male, Jamesburg, N. J., July 4, '9I (C. W. Johnson).

\section{Dolichopus corax ()sten Sacken.}

One female. California (U. K.), agreeing with Osten Sacken's description, but $+5 \mathrm{~mm}$. long. The fore coxæ have a thin silvery dust, and but little hair except on the lower and outer edge, where there are a few bristles; hind tibia with a row of about six strong bristles uniformly placed on the hind side, also a row of delicate ones on the front side.

This is the only species known that has black femora and enlarged fore tarsi in the male.

\section{Dolichopus laticornis I.oew.}

Two males, no locality (U. K.).

In one specimen the tegula have pure light yellow cilia: in the other, black ones with only a slight admixture of pale. The yellow of the middle femora is more extended than the description states, leaving, in the one case the basal half, in the other a mere basal ring, black. Middle tibiæ yellow. I should consider the hind tibiæ thickened. The convergence of the third and fourth reins is very slight.

A female from Conn. ( $\mathrm{L}^{\top} . \mathbf{K}$.), related to this species, has mixed tegular cilia, hind tibix nearly all black, wings infuscated along the veins, and minor differences.

Dolichopus gratus Low.

A single male, White Mts., Aug. (U. K.). The hind femora are ciliated the whole length, longest in the middle; in the other species with black femora, as far as known, the cilia are on the apical half. 
The middle femora also have cilia, shorter and mou delicate, throughout their length. The hind tibix are red only on the basal third.

A female from Florida (Johnson) has black femora, tegular and orbital cilia, and antenne. The pleure and sides of abdomen are noticeably silvery dusted, and the face also is silvery. It evideritly represents a new species of the foregoing group, but it would be difficult to prepare from a femalc a description from which the maic could be recognized.

\section{Dolichopus calcaratus, $\mathrm{n}$. sp.}

Differs from gratus lw. in the following respects: hind tibiæ wholly black; veins of wing black instead of yellow; fore coxæ even more densely hairy and bristly.

One male, lover, N. J., June is (C. W. Johnson). An examination of more material may yet show that in this case these characters are not of specific value.

\section{Dolichopus detersus Lom.}

Two males and one fcmale. St. Anthony Park, Minn. (Lugger); one female, Brookings, S. I)., June I 9.

Loew's brief latin dtscription may be supplemented as follows: Third joint of antenne rounderl, rather small; thorax rather high and prominent in front; hypopygium black, lamellæe small, oval, dirty whitish, part of the hairs yellow: anterior tarsi slightly longer than the tibia.

Female. Face widc, thinly dusted above, thickly below, silvery; hind femora not ciliated, hind tibize and the costa not thickened.

\section{Dolichopus kansensis, n. sp.}

Dark green, feet black, cilia of inferior orbit white, face wide.

Face and lower part of front yellow pollinose, remainder of front dark green. Antenna black, the third joint only moderately large, with a short arista. Dorsum of thorax dark green, pleuræ black with but little dust. Tegulx yellow with black cilia, halteres yellow. Abdomen dark green, toward the tip more black-green. Hypopygium black, the lamella rounderl, whitish, with a rather wide black border and small bristles. Legs from coxi to tarsi wholly black, at the knees with the faintest trace of red. Fore tarsi over $1 / 2$ times the length of the tibia, middle tarsi about $\mathrm{I}_{/ / 4}^{\mathrm{t}}$ times. Hind tibix incrassated; hind femora below with delicate blackish cilia of moderate length. Wings almost hyaline: costa slightly thickened; last segment of fourth vein as in the figure of Hygroceleuthus ciliatus.

I.ength, $4.2 \mathrm{~mm}$; of wing, 3.8 . 
One male, Kansas (U. K.).

Resembles $D$. oz'atus, lut has wider face, shorter and weaker cilia of hind femora, and fore tarsi nearly twice as long.

Dolichopus ovatus Low.

A puzzling species. A male from California (U. K.) may belong to it, but the tibiae are wholly black. From Loew's description it would seem that this is not a great discrepancy. The wings of the specimen in question are narrowed at the base.

I also doubtfully identify a female from Philadelphia (Aug. 7, Johnson) and one from Brookings, South Dakota, with this species.

Dolichopus albiciliatus Loew.

Wheeler. Psyche, May, 1890, 1. 398 (male).

A female, Dover, N. J., June 23 (Johnson), agrees well with the description except that the wings are brown along the veins to some extent. Another female, no locality, (K. U.), has hyaline wings and agrees well.

\section{Dolichopus convergens, $\mathrm{n}$. sp.}

Male. Dark green, cilia of inferior orbit white, femora black, hind tibiae black at tip, third and fourth reins of wing convergent at the tip.

Face narrow, silvery white; front green, not very shining; antennae black, third jointed rounded, rather large; thorax dark green, shining; pleurae black, a little dusted; tegulae yellow, with black cilia; halteres yellow; ablomen dark shinng green, not compressed; hypopygium black, its lamellae of moderate length, truncate in front, rather deeply jagged, with the usual black border. Coxae and femora black, trochanters and knees yellow. Fore and midlde coxae with a few bristles, and a little black hair and silvery dust on the fore side. Tibiae yellow, the hind ones black on the last fourth and slightly incrassate. Hind tarsi wholly black, anterior ones blackened from the tip of the first joint. Each tibia is about as long as the first three joints of its tarsus. Wings hyaline, narrowed basally; the third and fourth veins converge, and end considerably before the apex, about one third as far apart as the second and third.

Length $4 \mathrm{~mm}$.; of wing, $3.8 \mathrm{~mm}$.

Four males, Mt. Hood, Oregon, and one, Washington.

This species may be distinguished from albiciliatus and xanthocnemus by the absence of cilia on the hind femora of the male.

Dolichopus pachycnemus Lorw.

Seven males and four females, Brookings, S. D. Two bear dates of capture, June 12 and 16 . A well marked species, agreeing with description. 
Dolichopus brevipennis Meigen.

Four males, Skaane, Sweden, (Henry G. Klages). I have not seen it from North America.

Dolichopus albicoxa, n. sp.

Male. Cilia of inferior orbit and of tegulae pale, antennae black, first joint largely red below, hind tibiae black at tip.

Face of moderate width, white; front shining green; third joint of antennae rather large. Thorax green, very shining; pleurae green, white-dusted. Abdomen green, toward the tip coppery. Lamellae of hypopygium white on the basal half, the rest with a brownish tinge, from the black hairs inside, which show through; border blackish, with the bristles confined to the apex. Legs yellow, fore coxae with considerable white pollen, and some microscopic white hairs, but no black hairs or bristles except about six at the end; in certain directions these coxae appear almost white; middle and hind coxae black, broadly yellow at tip. Hind femora not ciliated. Last fourth or fifth of hind tibiae black, as also the whole hind tarsi. Fore tarsi one and one-half times as long as the tibiae; first three joints slender, stalk-like; fourth very short, black, compressed; last joint longer, oval, also compressed and black, the claws attached before the extremity. Wings slightly yellow, costa scarcely thickened.

Length, $5 \mathrm{~mm}$; of wing, $4 \mathrm{~mm}$.

'Two males, Massachusetts and Connecticut (U. K.). The female will probably be distinguished from that of brevimanus and socius by having fore tarsi longer than the tibiae.

Dolichopus longimanus Loew.

Three females, two from Hanover, N. H. (Weed), one from Custer, S. D., are readily distinguished by the dark color of the basal half of the fore coxæ.

\section{Dolichopus brevimanus Loew.}

Two female specimens, Massachusetts and Connecticut (U. K.), may belong to this species; but the differences among the females of this and several other species of the group are so slight that no positive conclusion can be arrived at without a larger amount of material.

Dolichopus socius Loew,

One male, Massachusetts (U. K.), is $3.5 \mathrm{~mm}$. long, but otherwise agrees well with the description.

Dolichopus palæstricus Loew.

One male, Dover, N. J., June I8 (C. W. Johnson). 


\section{Dolichopus splendidus Loew.}

Numerous specimens, Brooking, S. D., and four from Michigan; June 3 , 10, 12, I $_{5}$. The female Loew mentions in connection with this species undoubtedly belongs to it, as several of mine have the tip of the hind tibia with a trace of brown. One of the commonest northern species.

\section{Dolchopus dakotensis, n. sp.}

Cilia of inferior orbit and tegulae pale, antennæ black, posterior tarsi yellow to a considerable extent, male fore tarsi with three joints enlarged, the third and fourth white.

Male. Face narrow, yellow; antennæ wholly black; front green; thorax green, moderately shining; pleurae green, rather thickly dusted. Abdomen green, shining, the first segment on each side with a few long, pale hairs; lamellæ of hypopygium rounded, whitish, narrowly margined, jagged, and with black bristles. Fore coxae yellow, near the apex with a few black hairs and bristles, the remainder of the surface in front with a few microscopic white hairs, otherwise bare. Middle and hind coxæ black with yellow tips. Femora, tibiæ and proximal half of tarsi all yellow; hind femora with short, sparse, and delicate whitish cilia beneath; hind femora with the usual bristles behind, and a row of hairs down the front side; on the inner side below with a cluster of hairs. Fore tarsi double the length of the tibiæ; the figure gives a good idea of the structure, but does not bring out the third joint white enough. The outer side of the fifth joint has a satiny reflection. Wings hyaline, with yellow veins; costa thickened for a considerable distance before and beyond the first vein.

Female. Face wider; fore coxæ with delicate, sparse, bla:: hairs on fore side; fore tarsi one and one-third times the length of the tibix, the infuscation perceptible from the tip of the first joint in all the tarsi.

Length, $5.5 \mathrm{~mm}$.; of wing, $5.1 \mathrm{~mm}$.

Twelve males and one female, Brookings, S. D. Several were captured on June 16.

\section{Dolichopus edactylus Loew.}

A male and a female, Douglas Co., Kans. (U. K.), June 17 and 24. The female has the tegular cilia mixed with black, particularly on one side.

\section{Dolichopus variabilis Loew.}

Four males and four females; Mass. (U. K.), Pa. and N. I. ( I in son), Custer, S. 1); June 27, July I, August 4, 7, 14. 20. T.d hind tarsi vary in color as mentioned by Loew. 


\section{Dolichopus bifractus Loew}

Iowa (Osborn); Ohio and New Hampshire (Weed); Lawrence, Kansas; Brookings and Custer, S. D.; Fargo, N. D. Sixty specimens. This is perhaps the commonest Dolichopus throughout the northern states. The opaque thorax, red antenne, and broken fourth vein render a wrong identification very inlikely, even to a beginner.

\section{Dolichopus ramifer Low.}

Nineteen specimens, both sexes: Douglas Co., Kans. (U. K.), Brookings, S. D., Mich., Ames, Ia. (Osborn), Montana (Coquillett). Very easy to recognize in either sex. In Loew's diagnosis the cilia of the tegula are said to be yellowish, which is a misprint. In three other places he calls them black.

\section{D slichopus reflectus, n. sp}

Female. Antenna red; cilia of tegula black, of inferior orbit pale; fourth rein of wing broken, hind tarsi and tips of hind til)iie black. Face white, above a little yellowish; front blue. Thorax green, considerably dusted with gray; a narrow central stripe and a wider lateral one bronze; pleura blackish-green, with white dust. Abdomen bronze-green, not very bright. Fore coxe yellow, thickly clothed in front with minute black hairs. Posterior coxe black, with yellow tips. Fore tarsi scarcely longer than their tibia, infuscated from the tip of the first joint. Hind tarsi wholly black; hind tibia bristly, black at tip. Wings with a brownish tinge; fourth vein broken, the upper angle appendiculate in one wing, and very slightly rounded in the other; the portion between the two angles runs in a slightly oblique direction, so as to make acute angles with the other portions.

Length, $5.2 \mathrm{~mm}$; of wing, $4.7 \mathrm{~mm}$.

One female specimen, Philadelphia, May 30 (C. W. Johnson).

\section{Dolichopus vittatus Loew}

One male, Brooking, S. D. The relation among the males of this and the two following species is exceedingly close; as for the females, I do not see any characters to separate the present species from cuprinus, although representatives of both are probably before me.

\section{Dolichopus cuprinus Wriedemann.}

Nineteen specimens. The male cliffers from a'ittatus in having the fore tarsi ornamented with black hair, and the hind femora ciliated; from longipennis in the length of the fore tarsi, the presence of cilia on the hind femora, and the wider wings. The species is of wide distribution, the specimens examined being from Mass., Pa., N. J., Ohio, Kansas and South Dakota. 
Dolichopus longipennis laew.

Numerous specimens: Kansas, Tenn., Ohio, Pa., N. C., Fla., Ga., N. J. These localities range a little farther south than those given for cuprinus. The wilth of the wing seems a little variable.

Dolichopus hastatus Luew.

A single female, Mr. Hood (U. K.). The coloring of the middle tibiae and tarsi is distinctive. The species was rescribed from Sitka.

Dolichopus plumipes scopuli.

Eleven specimens, Brookings. S. D.: one male, Manitou Park, Colorado, July (Snow).

\section{Dolichopus flagellitenens Whereler.}

Psycue, May, 1890, 1. 3:39.

Nine males and three females, Brooking;, s. D., June 16 . The feriale has the hind tibiae scarcely a third black, last three joints of fore tarsi black, and lacks the sexual marks which distinguish the male. A single female from North Park, Col. (U. K.), is not distinguishable from this species.

\section{Dolichopus vigilans, n. sp}

Shining blue-green, antennae red, cilia of inferior orbit pale, of tegulae black, hind tibiae black at tip.

Male. Face yellow, front dark bluish green; antennae red, the apical half of third joint blackish. Thorax and abdomen shining bluish green, lusted with white along the sicles; hypopygium rather small, the lamellae of the usual size, whitish, rounded, with the usual jagged black border and bristles. Fore coxae yellow, with rather numerous small black hairs on the front side, beginning at the base; middle and hind coxae blackish, the latter more yellowish toward the tip. Hind femora with small yellow cilia below, near the tip only. Middle tibiae with a few long, divergent bristles; hind tibiae a little enlarged with a glabrous stripe the whole length of the inner side and another behind, and tipped with black. Fore tarsi one and one-half times as long as the tibia, the first two joints slencler, stalk-like, yellow; third joint slender, short, black at tip; fourth joint black, still shorter, compressed, with black hairs above: fifth joint longer than the fourth and wider, black, with black fringe above. The upper apical angle is acute, and the apical margins recede in a straight line to the claws. The empodium is modified into a snow-white little plume, fitting close to the fifth joint, and making it appear white at tip. A rather high power may be necessary to show the true condition. 
Wings hyaline, fourth vein rather abruptly bent, costa with a small, short thickening at the apex of first vein.

Female. Face a little lighter yellow, and wider; fore tarsi blackened from the tip of the first joint; hind tibiae simple, costa not thickened.

Length, $5.2 \mathrm{~mm}$.; of wing, $4.1 \mathrm{~mm}$.

A male and a female, Douglas county, Kansas, June 24 and 29 , (U. K.).

\section{Dolichopus comatus Loew.}

Five males and three females, New Jersey and Pennsylvania, May 30 to July 24 (C. W. Johnson). The first joint of the fore tarsi is, in both sexes, of nearly the same length as the remaining four. This is quite characteristic.

\section{Dolichopus brunneus n. sp.}

Female. Small, shining dark bronze species; antennae black, cilia of inferior orbit pale, of tegulae black, legs yellow.

Face broad, more so above, yellowis' gray; front greenish bronze. Thorax dark bronze, moderately bright; pleurae gray pollinose; halteres and tegulae yellow. Abdomen slightly more bright than thorax. Legs yellow; posterior coxae black, fore coxae yellow, with a trace of infuscation at the base, on the fore side with minute black hairs. Fore and middle tarsi blackened from the tip of the first joint, about as long as their tarsi. Hind tarsi and tip of tibiae black. Wings narrow, slightly tinged with brown, the anal angle not prominent; costa with a slight, long enlargement.

Length, $3 \mathrm{~mm}$.; of wing, $2.8 \mathrm{~mm}$.

One female, Brookings, S. D., June 18. The smallest North American species.

\section{Dolichopus incisuralis Loew.}

In the neighborhood of this species I have a number of females from Connecticut, (U. K.), New Jersey and Pennsylvania (Johnson), Ohio (Weed), and California (Coquillett). Some of them may belong to setosus. Not having any males, the separation of the two species is practically impossible.

\section{Dolichopus obcordatus, n. sp.}

Antennae black, cilia of inferior orbit pale, of tegulae black; legs yellow, coxae and tip of hind tibiae black; fore tarsi of male with the last joint flattened, obcordate, deeply notched at the end.

Male. Face yellow pollinose, front shining yellow-bronze, green along the edges. Antennae moderately large, especially the third joint. Dorsum of thorax green, rather coppery; pleurae dark green, 
with little dust. Abdomen green, coppery, the lamellae white, oval, with the usual dark margin, notches, and bristles. Coxae black, the fore ones a little lighter toward the tip. Hind femora ciliated with moderately long reddish or brownish hairs. Fore tarsi once and a half the length of the tibiae, the first three joints red, the last two black, compressed; middle tarsi black from the last third of the first joint; hind tarsi and last fourth of tibiae black. Wings hyaline, the first flexure of the fourth vein abrupt, in some cases minutely appendiculated, but usually a little rounded. Costa thickened very considerably, gradually diminishing toward the apex.

Female. Face whitish, fore tarsi plain, as long as the tibiae, blackened from the tip of the first joint; hind femora not ciliated.

Length, $4 \mathrm{~mm}$.; of wing, the same.

Three males and four females, Wyoming (U. K.), Manitou Park, Col., July (Snow).

\section{Dolichopus gracilis, $\mathbf{n}$. sp.}

Male; antennae wholly red, cilia of inferior orbit pale, of tegulae black, legs yellow, hind tarsi wholly black.

Face narrow, grayish yellow, more yellow toward the antennae; front green; antennae moderately long. Thorax greenish bronze, pleurae dark green, dusted with gray. Abdomen more pure green, the sides below whitish dusted, with yellow hair. Hypopygium black, the lamellae small, dirty whitish, rounded, deeply jagged, with the usual curved and branched bristles. Fore coxae light yellow, in front almost white, with microscopic, sparse white hairs. Niddle and hind coxae blackish at base, toward the tip more yellowish. Hind femora with a scattered row of long pale cilia below; all tibiae yellow. Fore tarsi one and one-half times as long as the tibiae, blackened from the tip of the first joint; hind tarsi wholly black. Wings slghtly yellowish, costa scarcely thickened.

Length, $4 \mathrm{~mm}$; ; of wing, $4 . \mathrm{I} \mathrm{mm}$.

A single male, Philadelphia, Pa., August 4 (C. W. Johnson).

\section{Dolichopus angustatus, $\mathrm{n}$. sp.}

Male. Antennae black, first joint in part yellow, third joint very wide and long, with a sharp point; cilia of inferior orbit pale, of tegulae black, last joint of fore tarsus enlarged.

Face grayish yellow, front shining violet; first joint of antennae slender, arista inserted beyond the middle of third joint. Thorax bright bluish green, with a bronze stripe each side above the root of the wing, and a very narrow one in the middle; pleurae dark green, light dusted. Abdomen somewhat bluish green, more bronze before 
the incisures. Hypopygium black, the lamellae whitish, rounded, with black margin, jaggerl near the apex, and curved black bristles. Fore coxae yellow, with small black hairs in front near the inner side, and some white dust; middle and hind coxae yellow, the former considerably, the latter slightly, brownish toward the base. Femora and tibiae yellow, the hind femora not ciliated. Fore tarsi nearly twice as long as the tibiae, not very slender; the first four joints plain, yellow; fifth joint as long as the third, black, flattened; fourth somewhat flattened, but not otherwise modified. Middle tarsi blackened from the tip of the first joint; hind tarsi wholly infuscated, still at the base not decidedly black; the color suggests that the specimen may be immature. Further material may show that the species properly belongs in the group with hind tarsi pale at base. Wings subhyaline, rounded at apex, the widest part beyond the midlle, narrowed toward the base. Beyond the louble flexure the fourth vein runs in a gentle curve parallel with the third vein, ending barely before the apex.

Length, $5 \mathrm{~mm}$.; of wing, $4.2 \mathrm{~mm}$.

A single male, Mlass. (U. K.).

Dolichopus lobatus Loew.

Numerois males and females, Brookings, S. D.; two from Agricultural College, Mich.; June s 4 and 16 are the dates of two specimens. An easily recognized species; the female has a few black hairs mixed with the yellow ones on the fure coxae, and lacks the lobes on the wing and other sexual characters; otherwise as the male.

\section{Dolichopus agilis n. sp.}

Antennae black, first joint yellow: cilia of inferior orbit pale, of tegulae black; legs yellow, hind tarsi wholly black.

Male. Face yellowish gray; front shining green. J)orsum of thorax shining green; pleurae blackish green, with gray dust. Abdomen shining green; hypopygium black, at base somewhat green or bronze. Lamellae light yellow, twice as long as wide, the black border wide at tip, which is a little jagged and has two or three crooked black bristles: upper margin smooth, witi short black hairs, changing to yellow near the base. Fore coxae yellow, with minute black hairs in front; middle and hind coxae black, tipped with yellow. Femora and tibiae yellow, plain. Fore tarsi almost once and a half the length of the tibiae; first three joints slencler, stalk-like, yellow, second and third each more than half as long as the preceding; fourth joint very short, wider than long, black, a few long black hairs above; fifth joint as long as the second, wide, black, with fringe of appressed black hairs above. Empodium a little enlarged, forming a snow-white plume reaching up half the width of the fifth joint, so 
that the latter appears to have a white tip. Midclle tarsi gently infuscated from the tip of the first joint. Wings with a grayish tinge, the fourth vein running rather far forward at its tip, costa not thickenerl.

Female. Fore tarsigradually infuscaterl from the tip of the first joint, one and one-third times as long as the tibiae; otherwise, after allowing for the sexual characters, the same as the male.

Length. $5 \mathrm{~mm}$; of wing $4.5 \mathrm{~mm}$.

()ne male, two females, Colorarlo (U. K.)

\section{Dolichopus marginatus, $\mathrm{n}$. sp.}

Antennae red, third joint largely black or brown; cilia of inferior orbit pale, of tegulae black; legs yellow, hind tarsi entirely black.

Male. Face whitish, moderately narrow; front with a violet reflection; black hairs of first joint of antenna rather large and abundant. Thorax dark green, shining; pleerae blackish-green, scarcely dusted. Abdomen shining dark-green; hypopygium black, lamellae large, roundish, white, with a wide black margin, sharply defined; at the apex the crooked branched bristles are as ustal, but from this point on around the upper edge, instead of the usual row of short and rather scattered bristles, is a row of very long, strong, nearly straight ones. They are black and curve gently toward the middle plane of the body. Near the apex they arise from a series of prominences which become gradually smaller. Fore coxae red with black hairs on the front side: middle and hind coxae black, both, especially the latter, considerably yellowish toward the tip. Femora and tibiae yellow; hind femora ciliated below on the apical half with a row of long. black hairs (the only instance I know in the genus where yellow femora have black cilia). Hind tibiae slightly infuscated at the apex, with a dark line on the inner side of the basal half, and the hind side wholly glabrous.

Fore tarsi slightly longer than the tibiae, infuscated from tip of first, blackened from the middle of the third joint; the fifth joint is as long as the fourth and has a slight projection above the claws, yet could scarcely be called flattened or enlarged. Middle tarsi gradually infuscated from the tip of first joint; hind tarsi wholly black. Wings rather broad and.short, with a slight grayish tinge; costa with a slight, short thickening.

Female. Fore tarsi as in the male; except the usual sexual characters, not differing from the male.

Length, 5.5-6 mm. ; of wing $4.2-4.5 \mathrm{~mm}$.

'Two males, eight females, Connecticut (U.K.). The color of the legs is more reddish than usual. 


\section{Dolichopus scoparius Loew.}

Two males and a female, Dover, N. I.. June 23; Philarlelphia, July I4 (Johnson); Mass. (U. K.). Wheeler (Psyche, May, I\$9o, p. 339) has described the very peculiar male lamellae. In my best preserved male the face is decidedly grayish yellow, and not at all white except at the lower border.

\section{Dolichopus duplicatus, n. sp.}

Male: antennae red, third joint black; cilia of inferior orbit pale, of tegulae black: legs yellow, hind tarsi yellow at base.

Face light yellow, rather wide: front green, opaque, with yellow dust. Thorax green, thickly dusted with yellow except in the neighborhood of the scutellum; brown stripes above root of wings distinct; pleurae blackish green, moderately dusted. Abdomen green, coppery, the sides a little light-dusted. Hypopygium dusted, opaque, shining black only at tip. Lamellae very large, yellow, the outer margin excised so as to leave an apical and an upper lobe; the apical margin in my only specimen is somewhat folded in and difficult to examine; it appears, however, not to have any strong bristles nor black border, but only a fringe of short hairs. Fore coxae yellow with black hairs on the front side; middle and hind coxae black, with yellow tips. Fcmora and tibiae yellow; hind femora not ciliated, hind tibiae plain. Fore tarsi one and one-half times the length of the tibiae, the first two joints slender and stalk-like, yellow; third joint also slender, blackish; fourth joint triangular, black, with a border of long black hairs above; fifth joint twice as long as the fourth, compressed, over half as wide as long, oval, projecting beyond the claws a little, black, with a black fringe above. Middle and hind tarsi gradually infuscated from the tip of the first joint.

Wings nearly hyaline, broad, the margin deeply notched at the fifth vein; costa scarcely thickened.

L.ength, $6 \mathrm{~mm}$; of wing. $5.5 \mathrm{~mm}$.

One male, State of Washington (U. K.).

\section{Dolichopus plumosus, n. sp.}

Male; antennae red, third joint black; cilia of inferior orbit pale, of tegulae black; legs yellow, hind tarsi at base yellow.

Face uniform pure yellow; front shining green. Thorax green, moderately shining; pleurae blackish-green, light-dusted. Abdomen bright green; hypopygium small, shining green or bronze at base, black at tip; lamellae pale yellow, elongated, broadly black-margined at apex, where they are also jagged, with curved and branched black bristles. Along the upper margin the black borcler grows narrower, and the bristles are small. Fore coxae yellow, with both yellow and black 
hairs on the front side. Middle and hind coxae black with yellow tip: hind femora not ciliated, hind tibiae thickened in the middle, not glabrous. Fore tarsi orer $1_{1}^{1 / 2}$ times the length of the tibiae; first two joints yellow, slender; third joint sleincler, brown; fourth joint short, black, enlarged, fringed above. obliquely truncate at tip; fifth joint longer than fourth, black, fringel above, compressed: the empodium forms a large, snow-white plume, lying just at the end of the fifth segment and apparently forming a part of it. Middle and hind tarsi infuscated from the tip of the first joint. Wings hyaline, of uniform width. cost with a short, rounded thickening at first vein.

Length, $4.5 \mathrm{~mm}$; of wing the same.

Two males, State of Washington (U. K.).

\section{Dolichopus occidentalis, n. sp.}

Male. Antennae black. first joint yellow; cilia of inferior orbit yellow, of tegulae black; legs yellow, last joint of male fore tarsi greatly enlarged.

Face uniform pure yellow; front shining green: second segment of antenna black, sometimes partly reddish on the inner side. Thorax shining bluish-green, near the scutellum sometimes more blue; pleurae green, scarcely dusted. Abdomen bright green, near the tip with rather long black hairs on the posterior margins of the segments; hypopygium shining black, at base with a greenish or coppery lustre, the lamellae whitish, elongated, narrow, with broad black border at tip and the usual bristles. Fore coxae red, with numerous rather coarse hairs on the front side; middle and hind coxae black, tipped with yellow. Femora and tibiae yellow, the hind ones plain. Fore tarsi $I_{1} y_{3}$ times the length of the tibiae; first two joints yellow, slender, stalk-like, third half as long as second, brownish, a little thickened; fourth exceedingly short, wider than long, black, with a few long hairs above: fifth nearly as long as the preceding three, flattened, obovate, with adense fringe of black hair above. Middle and hind tarsi blackened from tip of first joint. Wings hyaline, costa thickened somewhat before and far beyond the first vein, gradually tapering.

Length. $5.5 \mathrm{~mm}$.; of wing $4.5 \mathrm{~mm}$.

Two males, Washington (U. K.).

The females of ocidentalis and plumosus will probably be readily distinguished from each other by the color of the antennae.

\section{Dolichopus coquilletti, n. sp.}

Male. Antennae black, first joint chicfly red; cilia of inferior orbit pale, of tegulae black: legs yellow, last joints of male fore tarsi enlarged. 
Face grayish-yellow; front greenish-bronza; first joint of antennae narrowly black above, the remaincler red. Dorsum of thorax bronzegreen, consilerably dusted: pleurae blackish, with gray dust. Abdomen shining bronze, scarcely at all greenish, before the incisures somewhat coppery. Hypopygium black, at base disted, the lamellae whitish, rounded, with the usual jagged black margin and curved bristles at the apex. Fore coxae yellow, with coarse black hairs in front: middle and hind coxae black, with yellow tips. Femora and tibiae yellow, the hind ones simple. Fore tarsi I $_{2}$ times as long as the tibiae; last two joints slightly enlarged, black, with long hairs above; fifth joint as long as the third, not half as wide as long; empodium forming a small snow-white plume; third and second joints of tarsus gradually infuscated towarl the tip. Midlle and hind tarsi wanting in the described specimen. Wings almost hyaline, flexure of fourth vein quite abrupt, costa not swollen.

Length, $5.2 \mathrm{~mm}$; of wing $4.8 \mathrm{~mm}$.

A single male; California (Coquillett).

The hind tarsi being broken off, I have trusted to the general appearance of the specimen in assigning it a place in the table. The fore tarsi of the male would in themselves distinguish the species. See the figure.

\section{Dolichopus scapularis Loew.}

Numerous specimens: Donglas Co., Kans. (U. K.), Northumberland Co., Pa. (Klages), Ohio (Weed), Knoxville, 'lenn. (Summers). Dates of capture at Knoxville, May ig to June 27 ; in Kansas, June 18 to July 7 . The fore tarsi of the male are over once and a half the length of the tibiae, the same mistake occuring in Loew's monograph as in the following species.

\section{Dolichopus funditor Loew.}

Four males, one female, N. J. and P'a. (Johnson): June $2 S$ to July 25. Loew's description should give the length of the fore tarsi as over once ànd a half that of the tibiae, instead of once and a quarter. I do not doubt that I have the females of this and the preceding species correctly determined, but I base the lecision on the locality labels, associating each female with males from the same place. There appear to be no distinctive characters whatever.

\section{Dolichopus aurifacies, $n$. sp.}

Antennae red, cilia of inferior orbit pale, of tegulae black; legs yellow, hind tarsi at base yellow.

Nale. Face narrow, pure golden ycllow: antennae red, third joint sometimes a little infuscated; front shining green. Dorsum of thorax 
shining green: pleurae green with gray dust. Abdomen shining green; hypopygium small, with a greenish reflection at base, the remainder black; the lamellae have longer peduncles than usual, being inserted but little beyond the middle of the hypopygimm; they are oval, with the usual jagged apex and curved bristles; the black border is not very well defined, and there are some scattered black dots on the white ground color of the organ. Fore and hind coxae yellow, the former with small pale hairs on the front side; middle coxae yellow with two black spots on the outer side. Femora and tibiae yellow; hind femora not ciliated, hind tibiae thickened, the hind side entirely glabrous; fore tarsi once and a half the length of the tibiae, simple, gradually blackened on the last three joints; middle and hind tarsi infuscated from the tip of the first joint. Wings broal, short, sub-hyaline, costa scarcely thickened.

Female. Face grayish yellow, fore tarsi missing in my specimen.

Length, $4.8 \mathrm{~mm}$; of wing, $+\mathrm{mm}$.

Three males, one female: Knoxville, Tenn., May 16 and 17 (Summers); Lawrence, Kans., June +4 (U. K.).

\section{Dolichopus germanus Wheeler.}

Psyche, May, 1890, p. 341.

One male, and one female. Brookings, S. D. The fore tarsi of the female are perceptibly infuscated from the tip of the first joint.

\section{Dolichopus grandis, n. sp.}

Antennae red; cilia of inferior orbit pale, of tegulae black; legs yellow, hind tarsi yellow at base.

Male. Face whitish, yellow above; front green: tip of third joint of antennae somewhat infuscated. Head rather small in comparison with the large body. Thorax green, moderately shining, a narrow median stripe and two lateral, wider but less distinct stripes bronze; pleurae green, yellowish dusted. Abdomen coppery green; hypopygium more or less green at base, at tip black; the lamellae pale yeilow, long, narrow, truncate at tip, the upper angle slightly acute; apex jagged, black-bordered, with curved bristles. Along the upper edge are dark small hairs, the black border beginning near the tip. Fore and hind coxae yellow, the former with a few black hairs at base, the rest pale; the latter considerably black at base. Middle coxae black, broadly yellow at tip. Femora and tibiae yellow, long and strong; the hind femora on the inner side of the apical half with rather short yellow cilia; hind tibia narrowly glabrous on the hind side. Fore tarsi one and one-half times the length of the tibiale: first joint yellow, half as long as the tibia; second joint decidedly longer. reddish brown, exceedingly thin vertically, glabrous on the sides, with a row of uni- 
form black hairs above and below; last three joints black, of nearly equal length, compressed, the last joint slightly longer and more compresserl, with a cluster of white hairs at the tip above the claws. Middle and hind tarsi black from tip of first joint. Wings yellowish, long, romnled at tip, narrowed at base; the third vein keeps close to the second to a point opposite the flexure of the fourth, then makes a broad curve backward, so that the submarginal cell is very broad before its tip, and again narrowed; costa thickened from the top of the first vein for a considerable distance.

Female. Face grayish white, broad; wings a little narrowed at base, the third vein only a little curved. Fore tarsi missing in $m y$ specimen.

Length, 6.5 to $7.5 \mathrm{~mm}$.; of wing 6 to $6.5 \mathrm{~mm}$.

Two males, one female, California ( $\mathrm{C}, \mathrm{K}$ ).

\section{Dolichopus willistonii, $\mathrm{n}$. sp.}

Shining green, feet yellow, cilia of inferior orbit pale, of the tegulae black, fourth vein not broken, antennae red.

Male. Face yellowish white, front shining green, antennae red, at most the tip of the short third joint brownish. Thorax thinly brownish dusted on the dorsum, shining; pleurae green with white dust. Among the black cilia of the tegulae are sometimes one or two white ones. Abdomen shining green above, white-dusted on the sides below; hypopygium not very large, the lamellae somewhat triangular, white, with wide black border along the upper and apical side, at the tip jagged and provided with stout incurved bristles; the white disk of the lamella is punctulate on the outer side. Coxae, femora and tibiae wholly yellow, except that the middle coxa has on its outer side two dark spots, one small and one large, hind tibiae on the inner side glabrous for 23 its length, the tip glabrous behind. Hind and middle tarsi infuscated from the tip of the first joint; first and second joints of front tarsi stalk-like, yellow, third joint compressed, short, yellow, the sides bare, with a white, satiny reflection; fourth joint longer than third, still more compressed, black, the apical end white and not so high: as far as the black extends there is along the upper edge a dense fringe of black hairs; fifth joint on its lower edge about as long as the fourth, greatly compressed, black, with a fringe above; on the end just above the claws it is produced considerably and above this is excised in a sharp angle running half way to the base of the joint; above this it is prolunged far beyond the lower lobe, turns up a little, and ends in a broad, conspicuous snow-white tip. The black fringe along the top ends at the beginning of this white portion. Pulvilli yellowish white, not conspicuous. Wings hyaline; second and third reins close together and both turning back at the tip, the latter especially. 
Female. Face a little wider, legs and feet simple, second and third veins not so approximate.

Length, 5.5-6 $\mathrm{mm}$. : of wing, $5 \mathrm{~mm}$.

Eleven males and nine females, Douglas ('o.. Kans., June i 7 to July 7 (U. K.).

\section{Dolichopus pulchrimanus.}

Bigot. Ann. Soc. ent. Fr., I $\delta \delta \&$, Bull. bimens; p. xxx, (Spatichira pulchrimana); 1.c., I89o, 292 (Spathichira pulchrimanus).

M. Bigot has given us practically three descriptions of this species, as under the second reference he writes one in latin and one in French. Unhappily, his account of the male fore tarsi is essentially different each time, and the remaining characters are far short of tocating the species.

The genus Spathichira, founded by M. Bigot to inclucle all species of Dolichopus in which the male fore or middle tarsi are notably enlarged, is wholly untenable. The species funditor which he selects as a type, is a perfect illustration of the inapplicabilı! of the character for purposes of generic separation, since the female of $f n n$ ditor cannot be distinguisher in any way from that of scafularis. a species in which the males bave plain tarsi.

\section{HYGROSELEUTHUS LOOW.}

This genus was based on three European species of Dolichopus, in which the face reaches the inferior corner of the eye. Subordinate characters were found in the wide wings and in the males' elongated antennae.

The species at present known in North America otfer characters that interblend most curiously. Not one of the species could be distinguished in the female sex from Dolichopus by the length of the face alone. In afflictus and cronatus, Pacific coast species, the incision in the margin of the wing at the fifth vein is a good distinguishing mark; in latipes this is faint, in ciliatus absent. All the species but ciliatus have a thickened costa in the male, and the latter has a slight tubercle on the dorsal side of the rein. The Pacilic species have the typical development of the antennae, characterized by a long, densely hairy first joint with a bare, red swelling on the inner side; second joint also enlarged in somewhat the same way: third joint small, with a thick, short-plumose arista. The other species show this peculiarity to a less degree. 
Tables of Species of Hygroceleuthus.

MAIES.

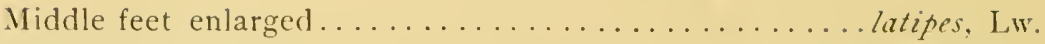

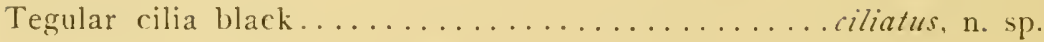
Second abtominal segment with long yellow hair on the sides...

Feet and abdomen plain, tegular cilia yellow.......... crenatus. O. S.

FEMALES.

I. First joint of antennae yellow, at most narrowly black along

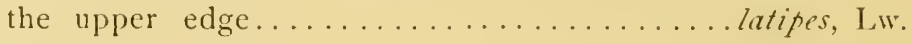

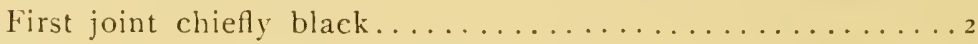

2. Cilia of tegulae coarse, wholly black.......... ciliatus, n. sp.

Cilia mixed above and below with yellow.............

3. Fourth vein with an unusually pronounced flexure..affictus, O. S.

Fourth vein with the ordinary flexure.......... crenatus, O. S.

\section{Hygrose?euthus latipes Loew.}

The figure in Loew's monograpin (N. A. Diptera II. pl. iii, I) incorrectly represents the middle tarsi of the male as being flattened. instead of compressed; the first joint of the antenna, also, is more hairy than shown, and the face of the female does not reach the inferior corner of the eye. In the description (p. 18), line ro, "tibiae" should read "femora." The first joint of the antenna is not at all blackened in most of my specimens; the thickening of the costa is peculiar to the males.

Numerous specimens. Brookings, S. D. (common in September): IVyoming; Connecticut.

\section{Hygroeeleuthus crenatus $0 . \mathrm{s}$.}

Numerous specimens from California, and two from Washington. Osten Sacken's material was not sufficient to enable him to discover one very interesting fact concerning the tegular cilia of this species and afflictus. In the male they are light yellow, fine and delicate; in the female they are of ordinary size and black, except a few of the smaller ones above and below, which are yellow.

A single male from Washington differs from the rest in having the antennae slightly longer, blacker, and more hairy; and the arista shorter and more densely hairy (see figure). These differences in a single specimen do not justify the erection of a new species.

\section{Hygroceleuthus aflictus 0 . s.}

One male and two females, California (Coquillett). The male is easily distinguished by the bunch of yellow hair on each side of the 
second abdominal segment. It reaches to the middle of the fourth segment in the specimen examined. A character shared by both sexes that readily separates the species from crenatus is the flexure of the fourth vein: it is much more pronounced in afflictus. The cilia of the tegulae, yellow in crenatus, are black in afflictus. Osten Sacken's short comparative description of the female of the former may be repeated for the female afflictus.

\section{Hygroceleuthus ciliatus; n. sp.}

Shining green, antennae black except inner side of first joint, cilia of tegulae long and black.

Male. Face covered with yellowish white pollen; palpi yellow, proboscis brown. Front green, antennae long; first joint red and somewhat enlarged on the inner side, above and on the outer side with stout black hairs; second joint black, rather long but not enlarged; third joint not very small, black with subapical bare arista. Cilia of inferior arbit light yellow.

Thorax shinning green, with strong bristles. Pleurae agreen, but slightly dusted; the area before the humeral spiracle and above the fore coxa has a black bristle and a few whitish hairs. Halteres and tegula yellow, the latter with long black cilia.

Abdomen green, somewhat bronzed, the sides of the first segment have some white hairs. Lam sll e of hypopygium small, black bordered and fringed as usual.

Fore coxa black on the posterior side; the anterior with fine white hairs and three or four black bristles. Middle coxæ black except at tip, with white hairs and black bristles. Hind coxa yellow at tip. Femora and tibix yellow; tips of hind tibix blackish. Tarsi simple, black from tip of first joint. Wings narrow, hyaline, the costa viewed at right angles to the wing is not thickened, still in a certain clirection there is a noticeable protuberance just beyond the end of the first vein. The fourth vein is strongly curved forward, and ends far before the apex of the wing. Posterior margin but little indented at the fifth vein.

Female. Face wider and shorter, costa simple. Antennæ slightly shorter, the third joint relatively larger.

Length, $4 \mathrm{~mm}$.; of wing, the same.

Two males, Custer, S. 1).. two females, Wyoming.

\section{Hygroceleuthus lamellicornis.}

Thomsun, Eurenies Resil. 511, 114 (Dolichopus).

This species was based on a single female specimen, evidently a near relative of affictus and crenatus; but the rather lengthy descrip- 
tion omits the distinctive characters. Baron Osten Sacken thought it could not be the same as crenatus, and there are exactly the same reasons, now that the female of afflictus is known, why it can not belong to that species. It has never been recognized.

Note.-The name agilis is preoccupied for the genus Dolichopus: I wish to substitute coloradensis for it in this article. 


\title{
New Genera and Species of Psilopinz.
}

\author{
li J. M. ALIRICH.
}

The genus Psilopus has heretofore occupied a place apart in the family Dolichopodidae. Notwithstanding the immense number of species, comprising some ninety in America alone (if we may trust the descriptions), no acceptable plan of dividing the gen's has yet been proposed. Bigot's attempt (Ann. Soc. Ent. Fr., Oct., ISgo, p. 268 ) is the latest. His high estimate of the value of the antennal modifications has led him to overlook other characters, and select, in two instance, a nodule or disk on the arista of the male antenna as the basis of a new genus. This is too slight a character for the purpose. The apical or dorsal insertion of the arista, which he uses to separate two groups of genera, would, if well-marked, be important; but when it is necessary to explain at soine length just how far up from the apex the arista may be and yet be "apical or subapical," the ralue of the distinction sinks into insignificance.

Loew (Mon. N. A. Dipt. II, 23I) suggested that the color of the tegular cilia seemed to offer the best ground for division of the genus. In the line of his proposition, I have found that these cilia, when black, are associated with four large bristles on the scutellum, and a third longitudinal vein of the wing which curves backward at the tip in the normal manner. When they are pale, the scutellum has only two large and usually two small bristles, and the third vein near its tip is distinctly curved forwarl, parallel or nearly so with the branch of the fourth vein. Thus we find ample ground in three distinct characters, applicable to both sexes, for the division of the genus. In an examination of about thirty species, these characters apply perfectly to all but one: in this, a South American species, the curved vein is associated with four large scutellar bristles and the tegular cilia are half pale and half black. This species I would include anong those with black cilia.

Adding to these two genera two more which are new to science, described in this paper, we have the section Psilopinae of the family Dolichopodidae thus characterized:

Fourth longitudinal vein with a widely divergent fork on the front side; or if not, then the head wider than the thorax, face wide, and the front deeply excavated.

(47) KAN, UNIY. QUAR. YOL. II, NO. 1, ,IULY, 1893. 
GENERA OF PSIIOIJINAE.

1. Fourth longitudinal vein not forkerl,

Aptorthus, n. gen. Fourth vein forked.

2. Tegular cilia black, third rein gently curved back at tip, scutellum with four large bristles, Psilopus Meigen.

'Tegular cilia pale, third vein distinctly curved forward at the tip, scutellum with only two large, and usually also two small, bristles. 3 .

3. Face wide, front deeply excavaterl, Gmamptopsilopus, n. gen.

+. Face narrow, front scarcely excavated, Leptorthethrum, n. gen.

The name Psilopus is preoccupied in the Mollusca, as Osten Sacken and others have mentioned. A new name should not be proposed for the dipterous genus without a careful examination of several of the older European works, which are inaccessible to me. It is probable that, as Bigot suggests, Psilopodius Rondani is the legitimate successor of the old name.

\section{GIAMPTOPSILOPUS n. gen.}

(gnumptos, bent).

Includes all that part of the old genus Psilopus in which the species have pale tegular cilia. Other characters are as above mentioned. Psilopus scintullaus $\mathrm{L}, \mathrm{w}$. bicolur. I,w., tener $\mathrm{L}$ w., and filipes $\mathrm{Lw}$, are typical species.

\section{APTORTHUS $n$. gen.}

(", without: p!erthos, branch).

Structure of the head as in Psilopus, front very deeply excavated. Posterior crossvein shorter and less oblique than in Psilopus, its anterior end nearer the middle of the wing: fourth vein with a rounded but rather short curve forward, at a distance beyond the crossvein equal to the length of the latter: beyond this curve gradually retiring to its former course, so that the first posterior cell has a long, slender, gently narrowed tip; the end of the fourth vein is before the apex. Aptorthus albiciliatus n. sp.

Male. Face broarl, with thin yellow pollen; fron: shining green, the two ocellar bristles black, a bunch of bristles behind these and another on each side next the orbit yellowish; antennae small, black, the arista dorsal, rather short, the hairs of the second joint of the antenna yellow; palpi and proboscis pale; cilia of the inferior orbit white, rather bushy. Thorax shining blue-green, with black bristles; pleurae slightly white dusted; tegula white, jts tip black, with long whitish-yellow cilia; halteres yellow, the peduncle brownish; scutellum with four bristles, the inner pair somewhat larger than the outer. Abdomen shining blue-green, with rather thick and coarse hair, which is black at the base and somewhat rusty, or in some lights yellowish, 
before the tip; on each side of the first segment a bunch of long yellow hairs; hypopygium black, closely folded up to the venter, the small apical organs yellow. Coxae green; the fore and middle ones. with long white hairs on the front side; trochanters yellow; femora green, rather broadly yellow at the tips, with white hairs, longer below, especially on the middle and hind femora; fore and middle tibiae yellow, the hind ones brownish-yellow; all the tarsi gradually infuscated toward the tip; the fore and middle tarsi are considerably, the hind ones scarcely, longer than their tibiae. Wings hyaline, the venation as described.

Female. Pollen of face white, lateral bunches of hair on the front brownish-black, the central bunch very short, whitish; hairs of the second antennal joint rather short, brown; abdomen with shorter hairs, lacking the white ones on the first segment; femora and hind tibiae wholly yellow, the former with short hair.

Length, $4 \mathrm{~mm}$.; of wing, $3.5 \mathrm{~mm}$.

Two males and two females, Westville, N. J., July 5 and 20 (C. W. Johnson).

\section{Aptorthus borealis n. sp.}

Female. Differs from the female of the preceding in having yellow fore coxae, brownish at base; on each side of the front near the eye are only a few small black bristles.

One female, Ramsey Co., Minn. (Lugger).

\section{Aptorthus nigripes n. sp.}

Female. Face white-dusted; palpi and proboscis brown; antennae black, second joint with black or dark brown hairs; front shining green, the two bristles of the ocellar tubercle black, behind the tubercle a cluster of small, white ones; on each side next the eye are a few white bristles and two black ones farther forward. Cilia of inferior orbit white. Thoracic dorsum shining blue-green; pleurae blackishgreen, with white dust; tegulae white with a narrow black edge and long white cilia; halteres yellow, abdomen blue-green, shining, with black hairs, which are mixed with a few paler ones at the sides near the base. Coxae blachish-green, with conspicuous white hairs. Femora of the same color, with black hairs except on the lower edge, where the hairs are pale and rather short; knees yellow; fore tibiae brownish-yellow, the middle. and hind ones, with their tarsi, brown. Fore tarsi brownish-yellow at base, darker toward the tip. Wings hyaline, venation as above described for the genus.

Length, $4 \mathrm{~mm}$. ; of wing, $3.5 \mathrm{~mm}$.

One female, California, Aug. 5 (Coquillett). 


\section{Apthorthus townsendii n. sp.}

Female. Face thinly dusted with white; front bright green, ocellar bristles yellow, the cluster just behind these minute, white; bristles of the sides of the front yellow; antennae black, hairs of second joint brown; cilia of inferior orbit white, thorax bright green with à thin coat of white dust, especially about the edges, the bristles long and strong, brownish yellow in color, those of the central dorsal region more blackish. Pleurae green, with whitish dust; halteres and tegulae as in nigripes; scutellum with a larga and a small pair of yellow bristles. Abdomen golden green, with short yellow hairs all over its dorsal surface. Fore coxae yellow with coarse yellowish-white hairs; middle and hind coxae black, with yellow tips and white hairs; femora, tibiae and tarsi yellow, the last toward the tip blackened, especially the hind ones. The hairs of the legs are few, short and pale. IVings hyaline, venation as above.

One female, Aztec, Arizona, July 2 I (Townsend).

Length, $4 \mathrm{~mm}$; of wing, $3.5 \mathrm{~mm}$.

\section{LEPTORHETHUM $n$. gen.}

(leptos, narrow; rhethos, fice).

Head wider than thorax; face long, narrow; antennae as in Psilopus, arista clorsal; front scarcely at all excavated, the lateral bristles small, acrostichal bristles in two rows; scutellum with a large inner and a small outer pair of bristles. Abdomen of male somewhat clavate, the hypopygium sessile, but little visible. Wings narrowed at base, sixth vein absent; third longitudinal vein curved forward at the tip; fourth vein forked as in Psilopus.

\section{Leptorhethum angustatum n. sp.}

Male. Antennae, proboscis, coxae and legs yellow; cilia of tegulae yellow; eyes almost contiguous on the middle of the face. thorax bright green above; abdomen green, venter and basal segments largely yellow.

Length, $2 \mathrm{~mm}$; of wing, $2.2 \mathrm{~mm}$.

One male, St. Vincent, West Indies (H. H. Smith).

A fuller description of this species will appear in an extensive paper on the West Indian Diptera now in preparation. 



\section{PLATE I.}

\section{GENUS DOLICHOPUS.}

Fore tarsi of males, side view.

Fig. 1. dakotensis n. sp.

Fig. 2. edactyls Loew.

Fig. 3. palestricus, Loew.

Fig. 4. angustatus n. sp.

Fig. 5. splendidus Loew.

Fig. 6. brevipennis Meigen.

Fig. 7. cuprins Wiedeman.

Fig. S. longipennis Loew.

Fig. 9. scoparius Loew.

Fig. 9a. scoparius Loew, last three joints from above.

Fig. 10. funditor Loew.

Fig. 11. flagellitcnens Wheeler.

Fig. 12. pachycnemus Loew.

Fig. 13. albicoxa n. sp.

Fig. I4. bifractus Loew.

Fig. I5. aigilans n. sp.

Fig. I6. plumosus n. sp.

Fig. I 7 . coquilletti n. sp.

Fig. I 8 . occidentalis n. sp.

Fig. 19. agilis n. sp.

Fig. 20. lobatus Loew.

Fig. 2r. duplicatus n. sp.

Fig. 22. grandis n. sp.

Fig. 23. villistonii n. sp.

Fig. 24. obcordatus n. sp.

Middle metatarsus of male, side view.

Fig. 25. comatus Loew.

GENUS HYGROCELEUTHUS.

Fig. 26. latipes, middle tarsus of male.

Fig. 27. crenatus O. S. tip of wing.

Fig. 27 a. crenatus var., male antenna, inner side.

Fig. 28. ciliatus n. sp., tip of wing.

Fig. 29. affictus Osten Sacken, tip of wing. 

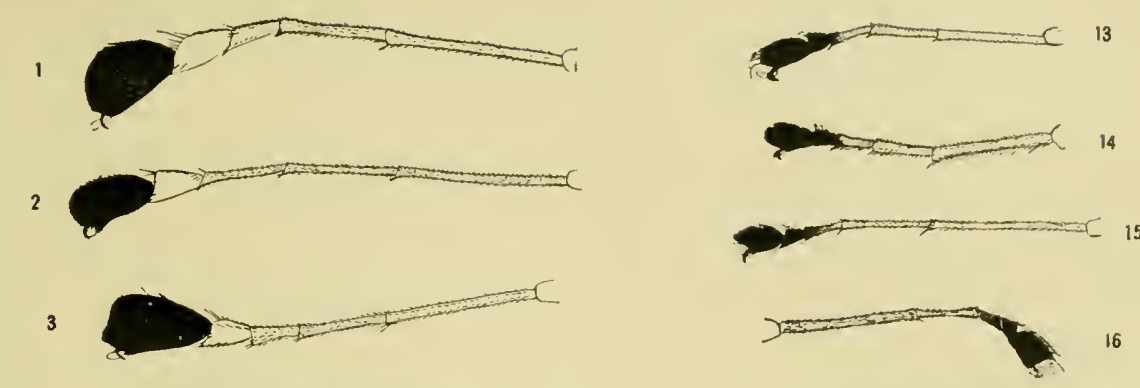

$40=x+x=$
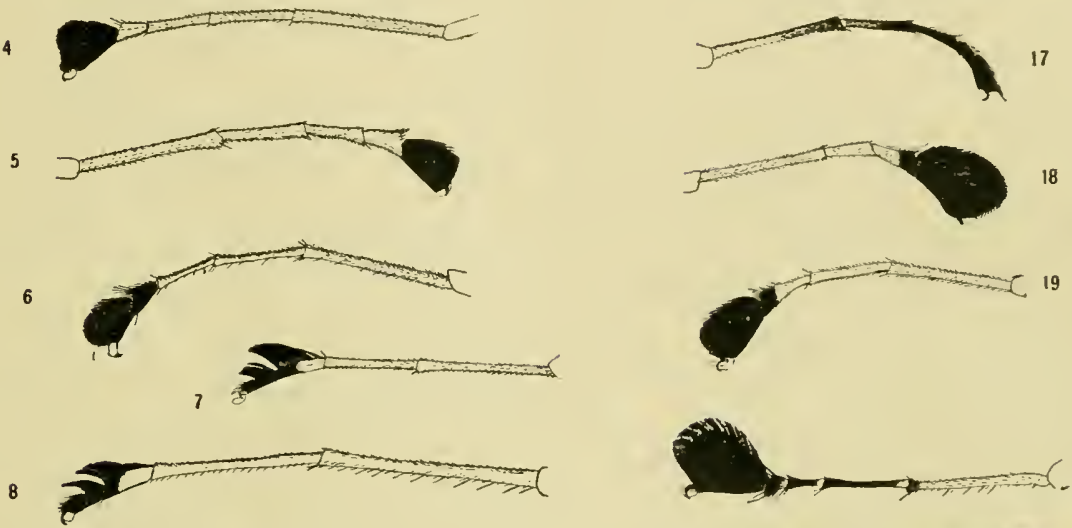

9

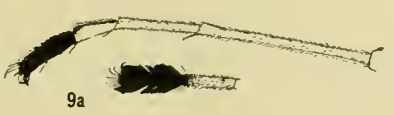

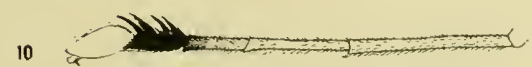
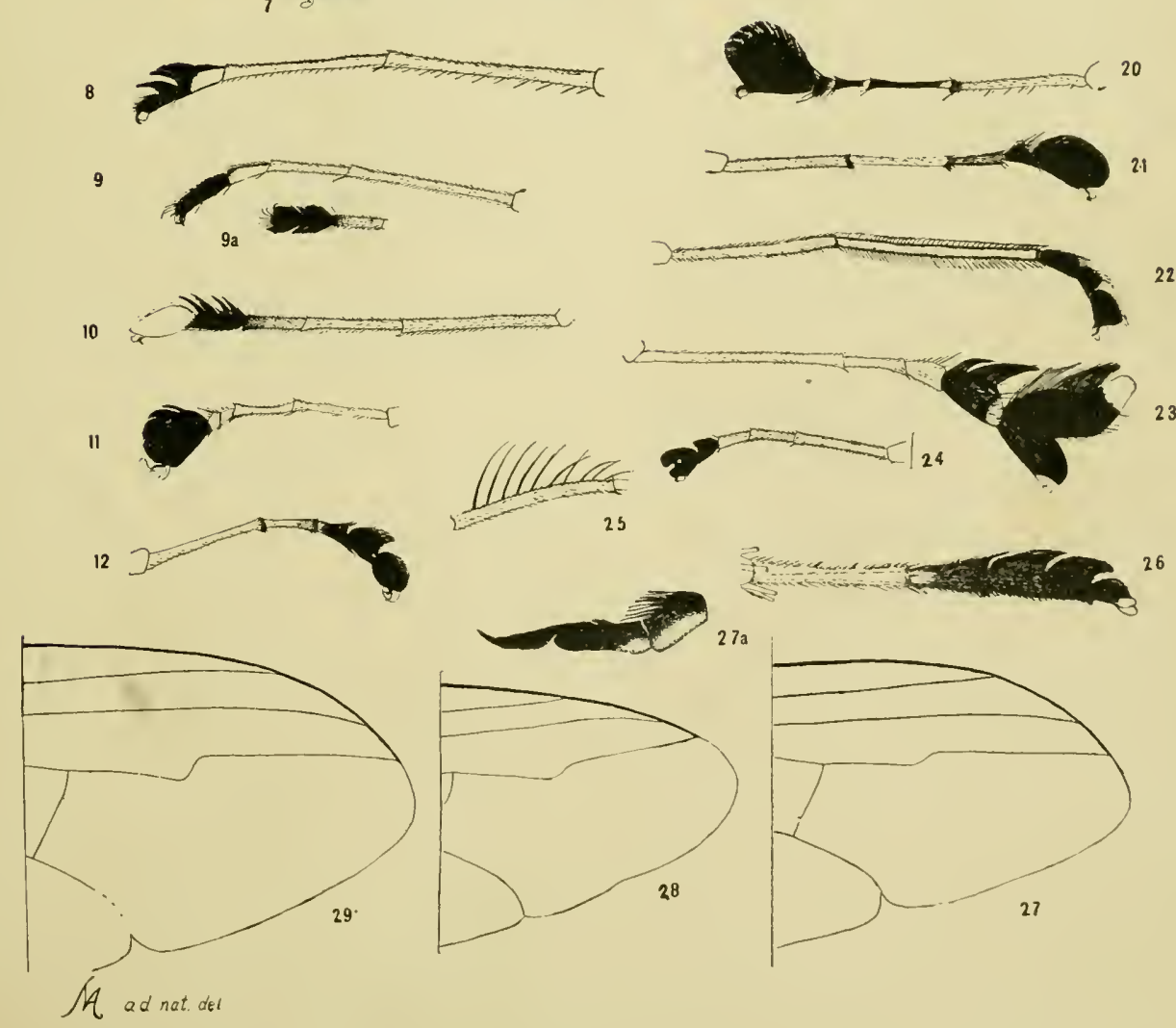

J. N1. Aldrich, ad. nat. det. 





\section{IMPORTANT CORRECTIONS}

On page 270, just before couplet 16 , add the line,

"Face of male not reaching as far as edge of eyes ............

On page 274 , second part of couplet 19 , add " 20 " at right hand end of line, setting the parenthesis one line lower; P. longicundu and abbreviatus should both come in the line beginning "20. Fore coxs black."

On page 250 , line 23 from bottom, for " 13 " reud "18." 



\title{
A Contribution to the Study of American

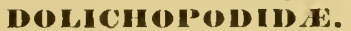

\author{
BY J. M. ALDRICH.
}

TABLE OF GENERA.

1. Fourth longitudinal vein with a widely divergent fork on the frout side...2. Fourth longitudinal vein generally without fork; if one is present it is nearly

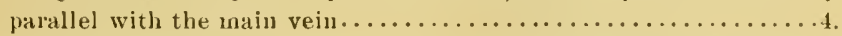

2. Cilia of tegulæ black, third vein converging to the fourth at tip, scutellum witlı four large bristles............... Psilopodiuus Bigot.

Cilia of tegula pale, third vein parallel with fourth at tip, scutellum with two

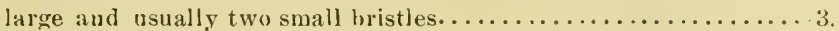

3. Face wide, vertex deejly excavated ........... gomosoma Guérin. Face narrow, vertex scarcely excavated........ Leptorlnethum Ald rich.

4. Thorax almost as broad as long; head wider than its own height or than the tholax, face very wide, vertex deeply excavated.

Vesorhaga Schiner.

Head and thorax uot as described....... . . . . . . . . . . . . . . . .

5. Fourth vein beut forward, forming an apical cross-vein ; posterior cross-vein oblique, parallel with the margin of the wing.

PJagioneurus Luew. Posterior cross-vein nearly transverse, usually no apical eross-vein........

6. Hind metatarsi with large bristles above ....... . Dolichopus Latreille. Hind metatarsi without large bristle above $\ldots \ldots \ldots \ldots \ldots \ldots \ldots \ldots \ldots \ldots$.

7. Hypopygium long, extending forward under the venter. . . . . . . . . . ๖. Hypopygium short, not extending forward under the venter..........20.

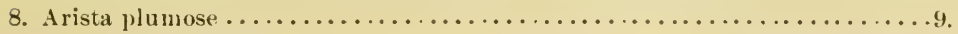

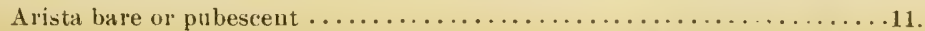

9. Face wide, bulging on the lower part..........Pelastoneurus Loew.

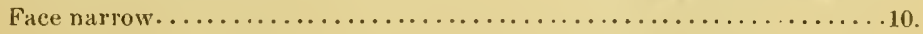

10. Thisl antenual joint of male large, elongate, excavated above

Leptocoryphat Aldich. Third autennal joint short, normal ............. Sareioums Aldrich.

11. Before the scutellum the posterior third of the dorsum is hollowed out, or at

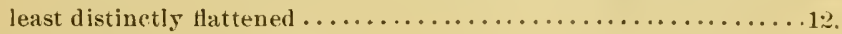

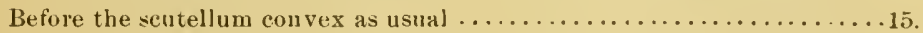

12. Posterior cross-vein distant, much more than its owu length from the margin

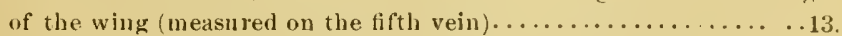

Pusterior cross-vein distant about its owu length from margin .......... 14 .

13. Second antennal joint prolonged along the inner sirle of the thirl.

Coeloglutus Ald rich. Second antennal joint not so prolonged, or forming a eup for the third.

'Tlurypticus Gerstaecker.

14. Third aud fourth veins parallel towards the tip; maritime species.

Third and fourth veins convergent; found on bark of trees.

Aphrosylus Walker.

Medeterus Fischer.

TRANS. AM. ENT. SOC. $\mathrm{XXX}$.

SEPTEMBER. 1904. 
15. The fice of the male rxtends below the eyes, hanging down before the month, apron like..............polymedom Osten Sacken. The face of the male reaches about as far as the lower edge of the eyes; head vertiealiy enlongated..............Tachytreoluns stannius. Face of the male reaching as far as the lower edge of the eyes, hut the head not elongated ..........................

16. Third and fourth veins parallel towards the tij $\ldots \ldots \ldots \ldots \ldots \ldots \ldots \ldots$. Thiml and fourth veins distinctly convergent. . . . . . . . . . . . . . 19.

17. Bristles of thomx yellow ................. Whrypticus Gerstaecker.

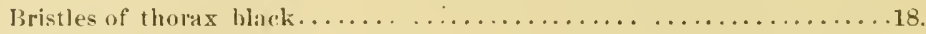

1\%. First antennal joint bare above.............p.rompeodes Wheeler. First antennal joint hairy above............ (19ymuptemus Loew.

19. The last segment of the forth vein grallually approaching the thiri.

IIercostomus L,rew. Last segment in the middle ahruptly enrving forward, then grarlually resuming its former course, ending near the thirl vein.

Paraclius Loew.

20. Costal vein extending only to the tip of the third vein, the latter part of the

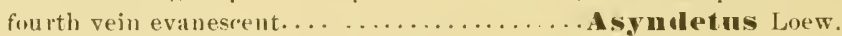
Costal and fomrth veins normal. . . . . . . . . .

21. First antennal joint hairs above. . . . . .

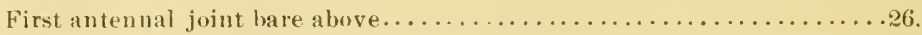

2:). Fonrth vein towards the tip stmoly curved towards the the third, nearly rearhing it in the margin............. plantonemrus Loew. Fourth vein parallel with the third, or sightly convergent.........

2:3. Arista dorsal, fuce very narrow, palpi small.......... Anepsius Loew.

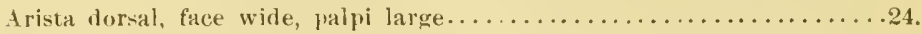
Arista nearly or quite at the tip of the large, pointed third joint.....25.

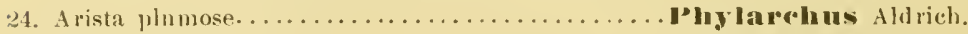
Arista pubescent ........................

25 . Proterior eross-vein distant about its own length from the end of the fifth vein..................... IIypochatuasus Mik. Pusterior cross-vein much nore than its own length from tip of fifth vein.

A rogy rat Mar'quart.

26. A concave or distinctly flattened, bare space before the seutellam . . . . . 27.

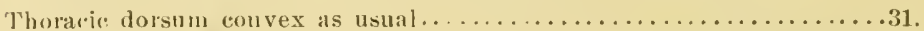

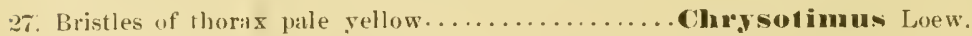
Bristles black, rajely brownish . . . . . . . . . . .

28. Fonrth vein parallel with the third beyond the eross-vein, or nearly so . 29. Fotuth vein converging towarls the third, either gradually or hy a double

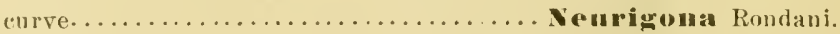

29. Acrostichal bristles present only at the anterior edge of thomx. very mi-

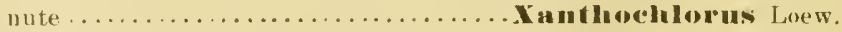

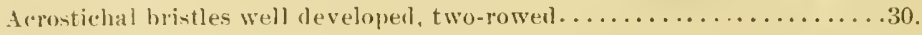

30. Very minute, blackish, opraque species ............. small, sellow species ..........................

* Thrypticus minor Ald. from St. Viucent, W. I., has the 3 rol and 4 th veins somewhat convergent. 
31. Wings elongate. the posterior eross-vein heyond the middle, less than its length from tip of fifth vein (Hydrophorina) ............... 32 .

Wings not clongate, posterior cross-vein scarcely besond the middle, more than its length from end of fifth vein (if less, the hind metatursus

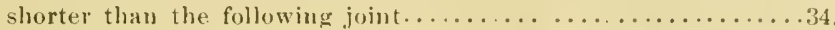

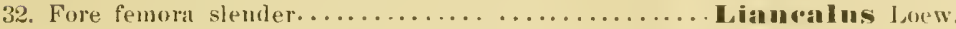

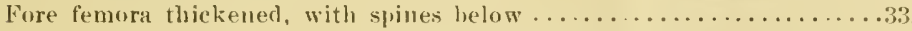

33. Spines of fore femora very short, thoracic dorsum withont well-marked pol-

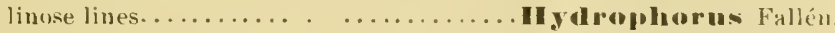
Spines of fore femora long, dorsum with pollinose lines... Srellus Loew. 34. Outer appendages of the hypopgium filiform; arista dorsal.

Nennatoproctus Loew.

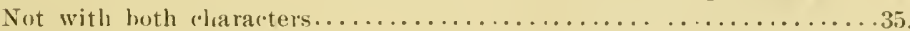

35. Second joint of antenna with a thumb-like projection along the inner side

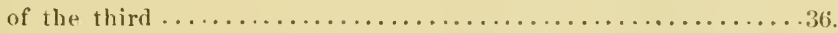

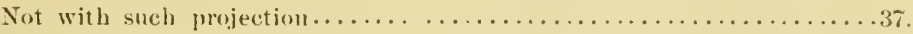

36. Face of fenale wide, the lower part projecting, roof-like.

symtormou Loew.

Face of female not so constructed ......... IParasymormon Wheeler.

37. Eses of male contiguous or nearly so below the antenna..........

Eyes of male contiguous or nearly so above the antenna.

Dianlurems Meig., pt.

Eres closest together at the level of the antenna ; middle legs of male distorted or with peculiar structure..... C'ampsicmemus Walker.

Eres of male not contiguous nor closely approximated . . . . . . . . .39.

38. Pulvilli of male fore tarsi conspicuonsly enlarged.. . Eutandsus loen.

P'ulvilli not emlarged.................

39. Thorax bright green, ahomen yellow, with a goud deal of silvery pollen.

Lejecontala $\mathrm{Lum}$

Not so marked. . . . . . . . . . . . . . . . . . . . . . . . . . . 40.

40. Face broad, the palpi large, reposing on the proboscis; pollinose species.

Thinophilus Wahlberg.

Palpi of ordinary size or else projecting lamelliform, free from the pro-

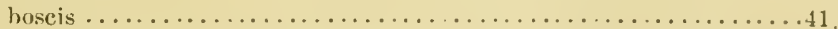

41. Third joint of the antenna in the male conspicuously long, anl-slaped, not much wider at base than the first joint .... Rlanploim Meigen.

Third joint long, lancet-shaped, willer than first joint.

Porphyrops Meig.

Third join short, the tip sometimes d raw out into a point ........42.

42. Abdomen of male with four blunt bristles at the tip.

Diandhon'ms Meig.

Abdomen destitute of these bristles . . . . . . . . . . . . . . . . . 4.

43. A rista nearly or quite apical.............. Chrykotus Meigen, pt.

Arista lorsal . . . . . . . . . . . . . . . . . . . . . . . . . . .

44. Costa thickened near the apex of the first vein; hind cross-veiu at riglıt angles to the costa .................. Truchophonus Low.

Costa not thickened; cross-vein slanting more or less towards the tip of the

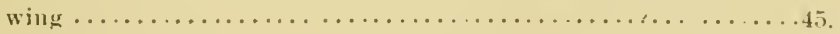

TRANS. AM. HNT. SOC. $\mathrm{XXX}$.

SHPTHBER. 1994. 
15. First joint of fore tarsus shortened in the male.

Nothoxympyenus Wheeler.

First joint longer than the following ............ Symprous Loew.

Since I prepared the table of genera of this family for Dr. Williston's Manual, many changes in the genera have occurred. The following notes explain these :

Of those omitted in this table:

Psilopus goes in Psilopodinus; Gnamptopsilopus in Agonosoma. Hygroceleuthus fills into Dolichopus.

Aptorthus is a synonym of Mesorhuga.

Pecilobothrus does not occur in North America, the species being herein assigned to Sarcionus.

Metupelastonenrus fills into Pelustoneurns.

Aphantotimus is a synonym of Thrypticns.

Ductylomyia falls into Neurigona.

Macellocerns falls into Tuchytrechus.

Lasiargyra fialls into Argyra.

Lyponeurus falls into Diaphorts.

()) added genera :

Aphrosylus and Tenchophorus are European genera found to vecur here.

Cologlutus was overlooked before.

Purasyntormon and Nothosympycnus are new genera by Wheeler.

Surcionus, Phylurchus and Ianthima are new genera by myself:

Of recent genera not included :

Tiphandrium, assigned to our fauna by Wheeler, does not really occur in North America.

Drepanomyiu is a synonym of Hypocharassus.

P'urhydrophorus falls into Hyárophorus.

Ianthotricha is a synonym of Thrypticus.

Symurthrus, revived by Wheeler, has heen rejected ly Mik, in favor of Syntormon.

The bibliographical references will be given in fill in my forthcoming Catalogue of North American Diptera.

\section{PELASTUNEURUS, PARACIIUS and SARCUNUS.}

These three genera are in some cases difficult to distmguish from each other; briefly, Pelastonenrus and Sarcionzs have a plumose arista, while that of Paraclins is hardly pubescent; the face in 
Pelastoneurus is wide and bulges below, while in Sarcionus it is nar. row and does not bulge.

To avoisl mistakes of generic reference, I have combined the tables of the three genera.

\section{Combination Table of North American Species.}

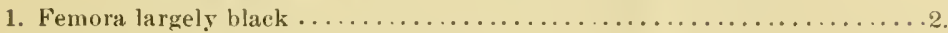

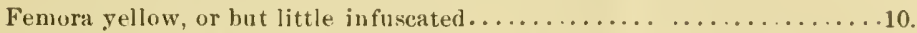

2. First part of costa greatly thickened in the male, noticeably so in the

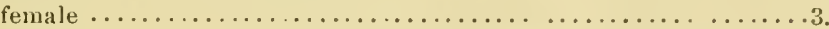

First part of costa not perceptibly thickened ........................

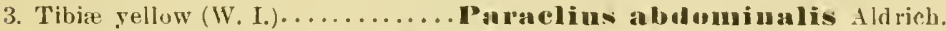

Tibie b]ack (La., N. Y., Cuba, Mex.). Paraclius albouotatus Loew

4. Fore femora rellow, middle and hind ones with the apical third and balf respectively black (Mex.)......Paraclius femoratus Aldrich.

Fore femora black, with yellow tips; middle black, with apical laalf yellow; hind ones yellow, with black tips (Cal.).

Pelastoneurus alissimilipes Wheeler.

Femora, at least of male, more uniformls black.................

5. Antennæ reddish, except the upper edge and tip; thoracic dorsum bright bluish green (W. I.) ..........Paraclius fuscicoruis Aldrich.

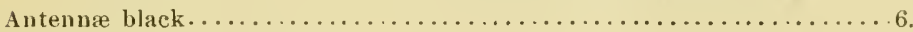

6. Tibiæ of nale wholly black $\ldots \ldots \ldots \ldots \ldots \ldots \ldots \ldots \ldots \ldots \ldots \ldots \ldots \ldots \ldots \ldots \ldots$.

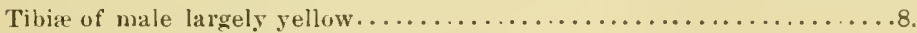

7. Upper half of the face bright green (Mex.)

Pelastoneurus hamatus Ald.

Upper half of face with whitish dust (W. I.). Pan raclins nigripes Ald.

8. Hypopygium small, romded (Mex.)...... I'araclius humeralis Ald̉.

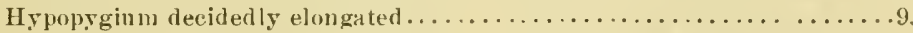

9. Face of male very narrow below (Tex.).... Paraclius pumilio Loew.

Face of male of uniform wirth (Fla.)...... l'anclius sentatus n. sp.

10. Wing of male with a rounded apical brown spot (Hex.).

Pelastonenrus bigeminatus Aldrich.

Wing in both sexes with several distinct brown spots........... $\ldots 11$.

IVing not spotted, or with one or two spots on the veins ..............

11. Fourth vein uniformly approaching the third (Mex.).

Pelastonenrus puncupenuis Sar.

Fourth vein bent abruptly towards the third (Fla.).

Pelastoneurus pictipennis Wheeler.

12. A spot of white pollen on the posterior part of the thorax before the scutelInm (N. Y., Chal., Fla.)....Pelastoneurus longieanda Loew.

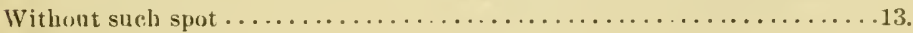

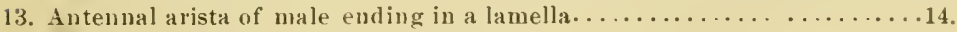

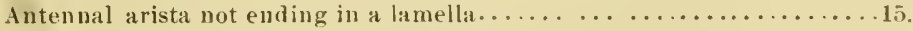

14. A rista of male long, tapering, thin (IV. I.).

P'straclius discilar A Alrich. Arista quite short. thick ( E. U. S)... Paraclius Claviculatus Loew. TRANS, AM. ENT. SH: $\mathrm{x} \times \mathrm{X}$. SEPTEMBER. 1904. 
15. Inuer claw of male fore tarsus enlarged and bent so as to form a suall hold. ing orgau (W. J., Mex.). I'elastounurus unguiculatus Ald.

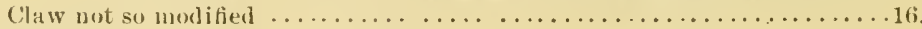

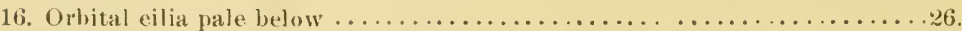

Orbital cilia black ... . . . . . . . . . . . . . . . . . . .

17. Tips of hind femora infuseated ahove. . . . . . . . . . . . . . . .

Tips of hind femora uot infuseated ... . . . . . . . . . . . . . . . .

18. Dorsun of abdomen deep violet in color; largu species (Cal., Ariz., S. D.).

Pelastoneurus -yancus Wheeler.

Dorsum of ahdomen not violet. . . . . . . . . . . . . . . . . . .

19. Dorsun of thorax violet (N. Y., Mass., Fla.).

Delastoneurus lammallatus Loew.

Dorsum of thorax not violet (N. Y., (al., Fla.).

Pelastoncinus longicaudat Loew.

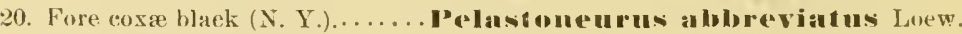

Fore coxæ yellow, except at base (N. Y., IHl, Mex.).

parlastoncurus lnubris Loew.

21. Hypopyginm short, the lanelle divided, forming four long filaments Kans.

S. D. . . . . . . . . . . pelastoneurus kamwasis Aldrieh.

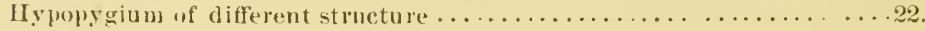

22. Dorsum of thorax opaque brown, with two fine gres lines; white spots absent from transverse suture (N. Y.. J11., Mex.).

Pelastomamus lugubris Loew.

Dorsum mole or less shining. the white spots distinct . . . . . . . . . . 23.

23. Fave of male in narrowest place not one-tenth the width of the head (Mex.).

Sarciouns flanvicoxa Aldrich.

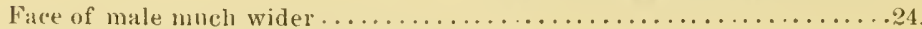

24. Face of male brown, lamella forked (Tex.).

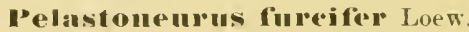

Face of male brown, lamellse not forked (ia.).

Pelastouenous proximus n. $s p$.

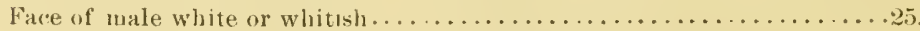

25. Thoracic dorsum deep violet in color (Fla., Ga., La., D. C.).

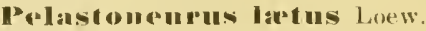

Dorsum only a little violet behind; hyphpginm slender, lamella small. oval

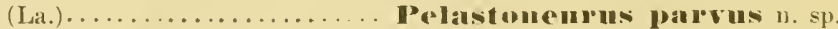

Dorsum onls a httle violet behind ; hy plygium thickened, the tip of the black lamella drawn ont into a long, eurved, black process (Quebec).

Delastaneurus lablatum n, sp

26. Face of male with a brown stripe in midulle, sides grepish white (Midda

States, Mex.............Pelasdonaund cognatus Loew.

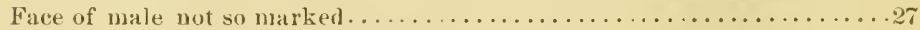

27. Lamallæ of hypopygium triangular, the upper hasal angle prolonged in a

long filament, projecting outwards or backwards .............

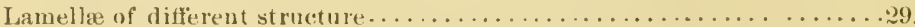

28. Color bright green; arista plumose (W. I., Mex.).

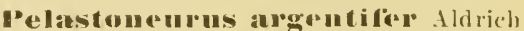
Color bright green; arista pubescent (W. I., Mlex.).

Paraclins liliter Aldrich.

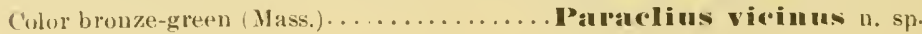


29. Hind femora infuscated aloug the entire npler edge i Fla.).

Daracilios propinquus Wheeler.

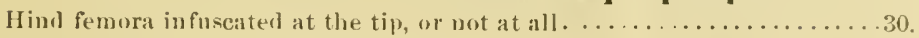

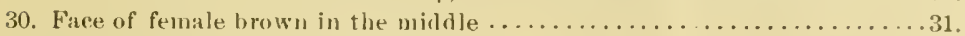

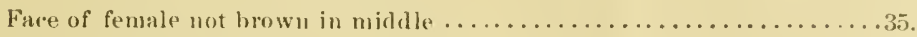

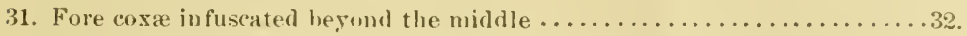

Fore coxa not or sarely infuscated . . . . . . . . . . . . . . . . . . . .

32. Lamellae of hypopreim straight, with mumded tips (U. S., Mex.).

Pelastoneurus vagans Loew.

Lamella curved, with acute tips (Cal.).

Pelastoneurus occideutalis Wheeler.

33. Arista of male long, with blunt tip (Wis., Ill., La.).

Pelastomeurus neglectus Wheeler.

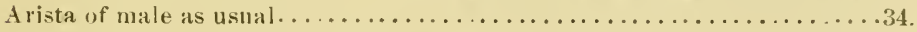

34. Lamellae of hypopygium black (Fla.).

Pelastomenrus florialanus Wheeler.

Lamelle yellow, or mainly so (W. I.).

Pelatomeurus faciciatus Roeder.

3i. Antenna whol!c black (W. I.).........Paraclius areuatus Loew.

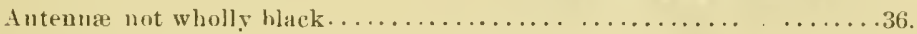

36. A double black spot before the root of the wing, of which the anterior part extends towards the midlle of the dorsmm (WV. I.).

Paracling quadrinotatus Aldriclı.

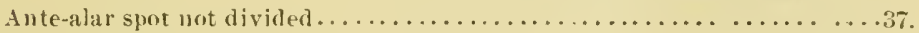

37. Thoravic dorsum with one or more distinct longitudinal lines......... 38.

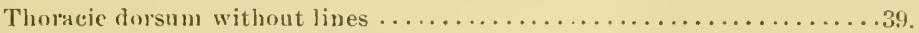

38. Thorax dark bronze-green (N. Y.).

I'elantoneurum alteruans Loew.

Thorax bright hlue-green (W. I., Mex.)..Warcionus limeatus Aldrich.

39. Upper part of the face bright green (IV. I., Mex.).

Pelastoncurns argentifer Alarich.

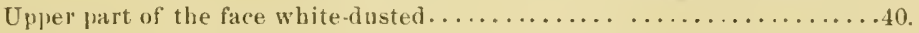

40. Last section of fourth vein curved in the middle (W. I.).

Pavaclius venustus Aldrich.

Same curved distinctly beyond the middle (W. I.).

Paraclius bellus Aldrich.

In the tahle, the section numbered 19 and 20 presents the greatest difficulty. I am unable to recognize abbreviutus in any of my material, and it may be the same as longicanda, in which the spot before the scutellum is sometimes evanescent. There seem to be some specimens of lamellatus in which the dorsum of the thorax is not violet but dark bronze. They may belomg to a distinct specie=, but I cannot settle the question with my material. In other re speets the table ought to work well after a little fimiliarity with it. Leptocorypha paco Aldrich, from St. Vincent, IV. I., is a near rela 
tive of Sarcionus. There is only one member of the genus, and it has large, elongated antenna, and the hypopygium is yellow.

Pelastoueurus scutatus n. sp.

Male.-Face wide, in the middle witls a shield-shaped brown spot, reaching entirely across; below and above the pollen is of a whitish or glancous color. The point of the shield reaches to the lower edge of the face in the middle, and there is a projection from the middle above also; so the white is divided into four spots. Antemme blackish, with a trace of rellow at the bases of the joints; arista feathered with moderately long hairs. Front blackish, with a steel-blue spot on each side; cilia of inferior orbit black.

Thorax rather opaque brown, hefore the sentellum with a violet spot; tegulæ yellow, witb black cilia; halteres with browuish knob; pleuræ blarkish, with little dust.

Abrlomen quite uniform greenish brown in color; hypopsgium hlack, large, the lamella smallish, rather narrow, black, with a few long black hairs on the edge and some finer ones on the onter side.

Legs in the described specimen with an immature appearance. The coxæ and femora distinetly black, the tibie and tarsi brown. In a well-matured specimen the tibire would probahly he partly yellow.

Wings uniformly infuseated, costa not thickened, eross-vein almost exactly at right angles to the axis of the wing.

Length $3 \mathrm{~mm}$.

One male, Biscayne Bay, Fla., collected by Mrs. Slosson.

Pelastoneurus parvus 1). sp.

Male.-Face wide, covered with bluish white dust; palpi yellowish; antennæ yellow, the third joint large, a little Jonger than the others together, rounded at tip, the apical half blackened; arista plumose, with rather long bairs. Front greenish brown, dull; cilia of inferior orbit black.

Thorax rather dull green above, with distinct violet reflections near the scu. tellum; the sutural white spot large and distinet; usual black mark above the wing also conspicuous; pleure dark green, whitish-dusted; balteres and tegulæ yellow, cilia of the latter black.

Abdomen green, only moderately bright; the first segment above distinctly brighter than the rest in my specimen; incisures with faint darker bands; hypolygium elongated, ratber slender, black, the lamellie dark brown, small and rounded, with small black bairs ou the margin, aud still finer ones, mostly yellowish, rather abundant on the outer surfuce.

Fore coxa yellow, a little infuscated at base; middle and hind coxa with yellow tips; femora and tibia yellow; tarsi very slightly infuseated from the first joint.

Wings rather rounded, subbyaine; the fourth vein with bend in the middle of its last section, approaching very close to the third, and ending cousiderably before the apex.

Length $3 \mathrm{~mm}$.

One male, Opelousas, La., from Dr. Hough. 


\section{Pelastonenrus falcatus n. sp.}

Mnle,-Orbital cilia black, face of ordinary width, convex below and concave above in the usmal form, with white pollen up to the root of the antemure, but not vers bright or silvels; palpi of the same color. Antenna yellowish red, the upper part of the third joint infuscated; arista with the nsual hairs. Color of front not observed. Thorax bronze-green, not very bright, the posterior part witl a slight coppery reflection; the sutural groove at each side has the usual hright white spot (this should, in all cases, be viewed from above, the posterior end of the insect being turned towards the light), and an elongated blark ve]vety spot lies behind the root of the wing, extending over the angle of the base of the scutellum. Pleure with thick grey dust; tegular cilia black, the tegulæ aud halteres pale yollow. Abdomen bronze-green, the sides with only thin grey pollen in spots on the segments, the sixth segment covered with pollen; hypopygium stout, rather long, entirely pollinose except on the ventral edge, black; the lamellge are black, with brownish hairs on the edge, and the apical angle is produced into a curved, stout, black, horn-like point, longer than the bod, of the lamella, rather sharp at tip, and provided towards the end with slender brown hairs, which form a distinct bunch on the inner sile hefore the tip. The upuer or inner pair of organs, called hy Loew the inner lamella, have in this species a slender form and brown color, nore yellowish at the base; they have a few slender, long dark bairs on the underside towards the tip. Fore cosæ wholly gellow, middle and hind ones black with the apical third rellow; remainder of legs pellow, the tarsi infuseated towards the tip, the front ones only on the last joint; hind metatarsus about two-thirds the length of the following joint. Wings moderately infuscated, with the third vein curving forward in the middle of its last section, thence almost straight to the margin.

Female.-Frout purple or bluish purple, the face with a broad hrown stripe, the upper part not very white. Thorax with a very distinct purple reflection on the posterior part; the velvety black spot on the sutural groove extends back over the root of the wing, and there is a second silvery spot, but much less bright, between its end and the spot which extends onto the corner of the scutellum.

Length $3 \mathrm{~mm}$.

One male, two females, Montreal Island, Quebec, September 1 and 8, 1901 (Chagnon). The head of the male was destroyed, after it had been examined. The structure of the hypopygium is very distinctive, while the brown stripe in the face of the female occurs in only a few species.

\section{Paraclins viciuss n. $\mathrm{sp}$.}

Male - Face rather wide, para\}lel, covered with brown dust, the upper part showing the green ground color. Antenua reddish sellow, the third joint slightly larger than usual, darker towarls the apex, which has a blunt point: arista with only microscopic pubescence. Front bright green. Cilia of inferior orbit white.

Thorax bronze-green, without any median stripe, near the scutellum in oecasional instauces with a more violet tinge; scutellum bright green; pleura with pale greenish dust. In a side view, the dust in the sntural groove is of the sane color; from above it has the usual appearance of a white spot. Halteres and tegula yellow, the cilia of the latter black. 
Abdomen rather coppery, with a uniforn covering of thin grey dust, which in sile view seems more concentrated on the sides of the segments; it does not hide the metallic color to any great extent. The abdomen is noticeably robust and rather short. Hrpopygiun small, black, with small, black, rounded lamella. which, however, have a long black filamentous prolongation at the inner basal angle, usually diflicult to pereeive. This has a hackward direction, and can usually he seen when the abdomen is viewed nearly from above.

Legs yellow, the fore coxa scarcely infuscated at base, middle and hind ones almost wholly black; tarsi only a little infuseated.

Wings greyish, venation of the typical form with considerable concavity backwarl in the last section of the fourth vein.

Length $2.9 \mathrm{~mm}$.

Female.-In these there is a faily distinct median line on the thorax, otherwise no material differenees.

Six males, two females, New Berlford, Mass, collecterl by Dr. Hough.

The species is closely related to propinquus Wheeler from Florida, but the latter has a distinct strije on the thorax in both sexes, the hind femora infuscated above for the entire length, ete. Professor Wheeler's description of propinquus does not mention the thoracic stripe, but it is very prominent in two males that Mrs. Slosson sent me from Florida.

\section{Pelastuneurus proxiuus n. sp.}

Male.-Face moderately wide, with brown dust, which in some specimens is a little paler close along the lower edge; antenne yellow, the third joint somewhat elongated, brown at the tip; arista moderately plumose. Front shining, somewhat steel-b]ue on the sides. Cilia of the inferior orbit black.

Thorax dark green, with the usual dark spot on the side, and white one in the sutural groove; before the scutellum with a listinct violet tinge; pleurse black, with grey dust; halteres and tegula yellow, cilia of the latter black.

Abdomen bronze-green, on the sides of the segments with patehes of white lust; bypopygium elongate, black, the lamella enturely black, rather long, a little pointed, with a thick row of slender, long hlackish hairs on the edge. Above the lamella are two shorter filament-like organs (the "immer lamellæ " of Loew), dark brown in color, whieh bave some slender brown bais in one or two tufts near the tip.

Legs jellow, middle and bind coxe about half black, tarsi very slightly infuseated.

Wings subhyaline, fourth vein bent gradually about its middle, ending considerably hefore the tip.

Length $2.9 \mathrm{~mm}$.

Female. Face brown in the middle, whitish along the sides; otherwise not differing materially from the male.

Five males, one fenale, Opelousas, La., from Dr. Hough.

Except for the lamelli being so very different, I should have taken this for Pelustoneurus furcifer Lw. 


\section{IPSI LAR(DI) I NUS.}

Bigot, Anuales Soc. Ent. France, 269, 1890.

Aldrich, Canad. Ent., Aug., 1904, 246.

The genus is represented in America by a lare number of species, especially in the warner regions. Many were describerl by the early writers without mentioning the essential characters. When I came to work up the Mexican and Central American Dolichoporlidae for Biologia Centeali-Americana, I found it necessary to molertake a thoromgh study of all the American species, si) far as they conld be made out from the rich material furnisher me, my own collection, and the lescriptions. 'The results, as fur as they pertain to the fauna in that work, will he foumd in Biologia, Diptera, I Suppl., 350-364, where twenty-three new species are described, and a table of species given, the old name Psilopus heing userl.

I find myself with a considerable residum on hand, consisting of four new North American and two South American species, which for the sake of completeness I mentioned in my table, but could not publish at that time on account of their heing extra limital. The descriptions are given herewith, preceded by a table of the American species known to me (pilosus is the only exception-I have not seen it).

TABLE OF MALE SPECIES.

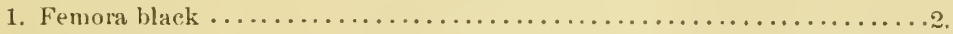

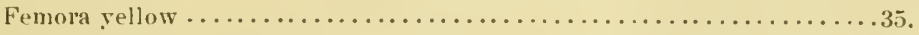

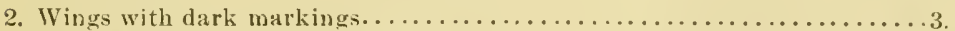

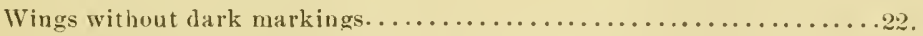

3. Fore tarsi with dense hlack fringe on sides of 4 th and 5 th joints, midrle tarsi with 2nd and 3 l joints less broadly fringed (Mex.).

bifimbriatus Aldrich.

Fore tarsi of different structure... . . . . . . . . . . . . . . . .

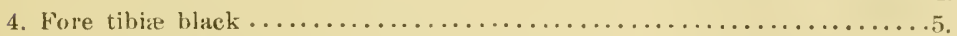

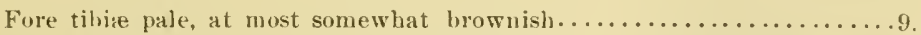

5. Face with numerous, delicate, pale hairs (U. S.)....palibulatus say.

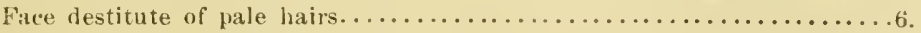

6. Second joint of antennæ with many very long bristles............

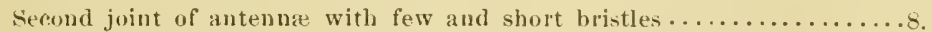

7. Last four juints of fore tarsus short, subequal (West. U. S.).

These joints of gradually decreasing length (West. U. S., Mex.).

melampus Loew.

४. The brown crossbands broadly connected on the fourth vein, leaving a round hyaline drop in the first posterior cell (Brazil).

ruttula Wiedemann.

Crossbands not connected behind; 5th joint of fore tarsus slightly compressed, with silvery reflection on inner side (Mex.)...practaus Aldrich. 
9. All tarsi wholly black (Brazil)............... gutula Wielemam. Fore tarsi wholls pale, middle ones hlack, with narow silver fringe above on last two joints (Mex., Brazil)........... dillusus Wledemann. Fore and middle tarsi little infuscater, 4 th joint of latter pure white, not enlarged (W. I., Mex, Brazil) ................

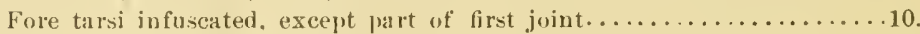

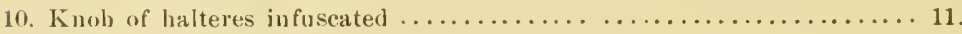

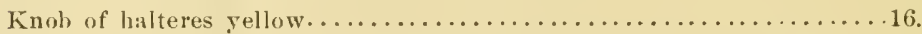

11. Wings with only a faint clond, before the third vein...cilipes Aldriel. Wings with two crossbands, on at least the hind crossvein iufuscated....12.

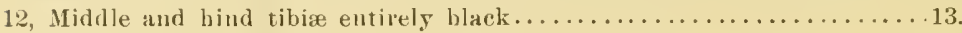

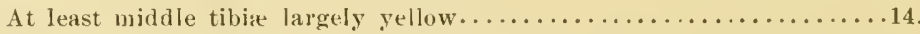

13. Middle metatarsi ciliated above (Cuba) ............ pilosus Loew. Iiddle metatarsi not ciliated above (Mex.)....... inoruatus Aldrich.

14. Middle metatarsi ciliater (Mex., Brazil).........triseriatus Aldrich.

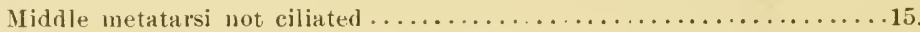

15. Third and fourth joints of hind tarsi subequal, a little swollen (Mex.).

alricauda Aldrich.

These joints of normal structure (Cuba, Jamaica, Brazil).

jucundius Loew.

16. Apjeal third of fore coxa, with trochauter and base of femur, yellow (Mex.). coxalis Aldrich.

Not more than extreme apex of fore coxa yellow...................

17. Middle tibia with a row of small bristles on the front of the inuer side, extending the whole length (Mex.)............. gemulis Aluich.

Middle tibiæ with a row of stout bristles on onter side, micldle metatarsus

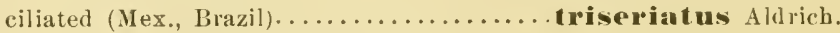

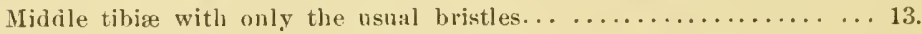

18. Last two joints of hind tarsus flattened $\ldots \ldots \ldots \ldots \ldots \ldots \ldots \ldots \ldots \ldots . \ldots \ldots$.

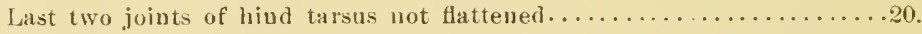

19. Crossbands broad, including half the wing (Brazil)...grateilis Aldrieb. Crosshauds narrow, scarcely a fourth of the wing darkened (Mex.).

depressus Aldrich.

20. Middle tarsi entirely infuscated (Mex.) ........ purpuratus Aldrich.

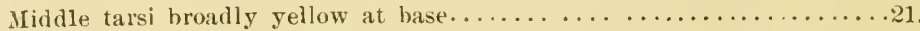

21. Hypopgginm minute, appendages incouspicuous (Mex., Brazil).

similis Aldrich. Hypopsgium large, the appendages large, flattencd, black (Mex.).

atrolamellatus Ald rich.

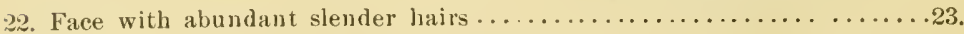

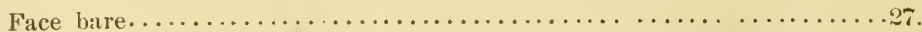

23. Face with dark bairs (Mex., Brazil) ............barbatus Aldrich.

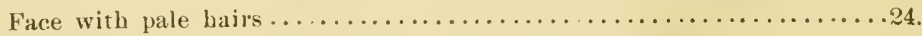

24. First joint of middle tarsus beset with crooked bristles. . . . . . . . . 25 .

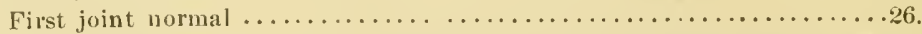

25. Tip of abdomen with a tuft of strikingly long hairs (U. S., W. I., Mex., S. A.)............... (cundatulus Loew) caudatus Wiedemann. Tip of abdomen with only ordinary hairs (U. S.) . . scobiantor Loew 26. Middle tibiæ with a strikingly long apical spur (U. S.)...cal learatus Loew. Middle tibia without unusually long spur (U. S.)........ inermis Loew. 
27. A rista at least two-thirds the length of the entire body $\ldots \ldots \ldots \ldots \ldots \ldots 28$.

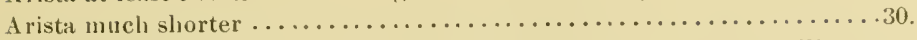

28. Arista ending in a sntall disk, fore metatarsus not with long cilia above (Mex.)...................... nobilissinus Aldrich. A rista plain, fore metatarsus with long cilia above .................

29. Appendages of hrpopygium pale, middle metatarsus also ciliated (C. S.).

coniatus Loew.

Appendages of bypopygium blackish, middle metatarsus plain (U. S.).

crinitus u. sp.

30. Thoracic dorsum covered with thin white dust, front deusely silvery-polli-

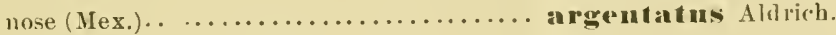

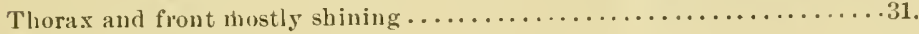

31. Costa with a row of erect cilia . . . . . . . . . . . . . . . . . . . . . . .

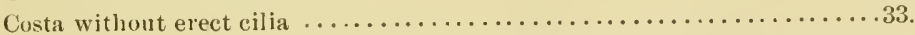

32. Second joint of fore tarsus shorter than any of the following (U. S.).

(ciliatus Loew) munalus Wiedemann. Seeond joint longer than any following (Mex.)......... hiltipes Aldrich.

33. Middle metatarsi with erect cilia above (Mex.)......... ciliipes Ald rich.

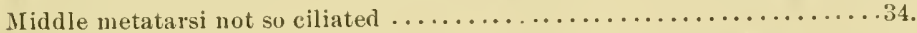

34. Middle tibiæ yellow, color of body purple (Mex.)....pumpurems Aldrich. Middle tibir yellow, color of body green (Mex.)..... forcipatus Aldrich. Middle tibiæ black (U. S., W. I.) .............hrysoprasins Walker.

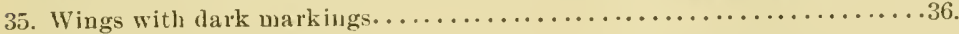

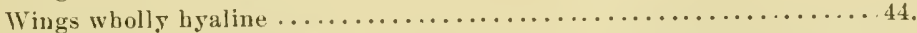

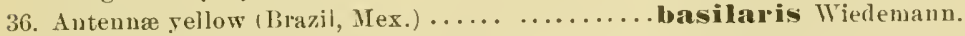

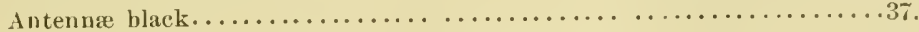

37. The hyaline space between the crossbands extends forward to the second

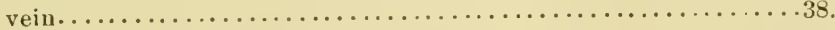

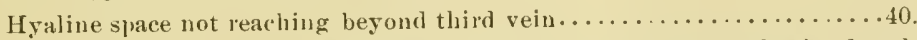

38. First joint of fore tarsus white at tip, the following joints black, the fonrth fringed above with black (Mex.).......... interceptus Aldrich.

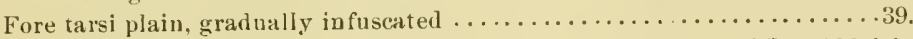

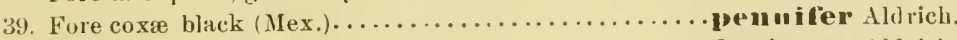

Fore coxæ yelllow (Mrex.) .....................

40. Cilia of tegule pale ou Jower half, third vein curved forward at tip (Brazil).

iniperator u. $\mathrm{sp}$.

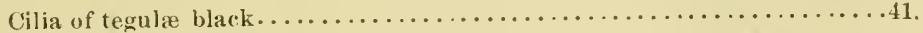

41. Second and thirds joints of fore tarsus stout, swollen, bristly (Mex.).

clavipes Aldrich.

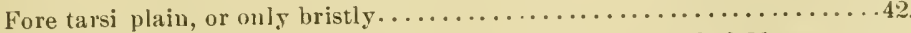

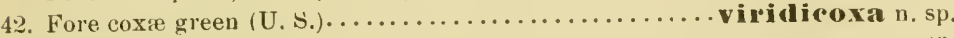

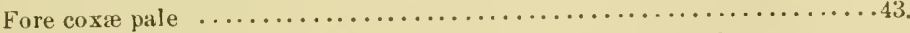

43. Middle metatarsus with a row of erect cilia on fore side (U. S.),

Middle metatarsus plain (U. S.) ....................... sipho Say.

44. Face with numerous pale hairs (U. S.) . . . . . . . . . flavipes n. $\mathrm{sp.}$

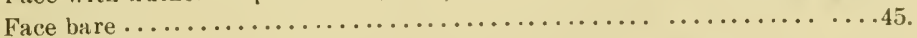

45. Middle metatarsi greatly elougated, ciliated (W. T.) . . . insmlan is AIdrich. Middle metatarsi plain, short (Mex.).............tonsus Aldrich

TRANS. AM. ENT. SOC. $\mathrm{XXX}$.

OCTOBER. 1904. 
Psilopodinus pilicornis sp. nov.

Male.- Wholly green and black, no yellow whatever, wings with two crossbands. Face dark green, but little dusted; antennæ black, second joint with about 12 stont bristles, whirh are longer than the antemua itself; palpi also with (juite noticeahle black hairs; front dark green, with slender pale hairs on the sides, some of which have a hrownish cast. Thorax dark green, plewre but little dusted; halteres and tegula black. Abdomen brighter green, a black band on the anterior edge of each segment; these bands are willer on tbe apical segments, and on the last two cover lualf or more of the width; hympyginm small, black. Legs blark, the femora greenish; fore tarsi much longer than the tibix, first joint longer than all the rest, with a row of small hairs on the uncler side and some small bristles on the outer side near the end, also a small enlargement below at the tip; second and third joints short, equal, enlarged helow; fourth and fifth longer, equal. Metatarsus of middle foot as long as the tibia, on the upper side a row of extremels fine erect cilia, especially distinguishahle at the base. Wings with a spot in the first basal, and the usual two crosshands brown; the bands are rather small. but in mature specimens distinet; in many teneml specimens the are faint.

The hairs on the incisures of the abdomen are longer and more erect than in most of the genus.

Female.-Halteres with pellow knob, few and short bristles on the antema and abdomen. hlack bands of abdomen atmost wholly absent.

Length 4-5 mm.

Many specimens: Lewiston, Idaho; Craig's Mt., Idahn; Seattle and Colfax, Wash.; Cal. (Coquillett and Baron, specimens collected by the latter being received by me from the Univ. of Kams.).

The common western species, differing from melampus chiefly in the short joints in the male fore tarsi.

Psilopudinus gracilis sp. nov.

Hule.-Face blue-green, but little dusted; antemnæ small, black, the second joint with few hairs, longest above; vertex deeply excavated, with few small hairs. Thorax bright green, rounded, the siles with a light greenish gray dust, in certain lights much more white. Halteres yellow, stem whitish. Ahdomen unusually slender, with broad black hands; the metallic parts of the last two segments are violet; on the last four segments more than half is back (but this is in only one specinen); hypopygium uinute, black, with four finger-like projections, blackened at tip. Coxa and femora black, the fore and middle trochanters cellow, and the fore coxa themselves rather brown than black; tibix yellow, the tarsi all gently infuseated from the base. Fore femora shorter than the tihix, the tarsi fully double the length of the tibize, slender and apparentl s free from hairs of any size; the fore tibize have ou the outer side some three or four small bristles; nidddle tibiæ longer, with about the same bristles, their tarsi once and a half their length. slender, plain; hind tibise rellow, hut infuscated at hase and tip, hairy, especially on the inner side; the tarsi black towards the end, the last three joints are slightly thatened, short, a little concave helow. Wiugs with very bload crosshands, which include more than the apical half of the area, and entirely reach the hind margin at the apex of the fifth vein; they are connected on the fourth vein, so as to enclose a large, rather square hyaline spot in the 1st posterior cell; the anterior fork of the fourth vein runs toward the base of the wing for a distance, then makes a short but rounded turn and runs to the tip. 
Tegula and their eilia black.

Length $6 \mathrm{~mm}$.

One male, Chapada, Brazil (Dr. Williston).

\section{Psilupodinus crinitus sp. nov.}

Male.-Deep green or blue species, very bright, the bristles of head, thorax, abdomen, and fore tibix greatly elongated, many of them wav toward the tips; antenne black, the arista over two-thirds the length of the entire hods, whitish at tip; appendages of hypopsgium small, blackish; all coxie, truchanters and femora black, tibix, except the extreme tip of hind ones, yellow; hind tarsi wholly, the others but very slightly, infuscated; fore and middle tarsi slender. elongated, the fore metatarsus with long cilia ahove, otherwise the tarsi are of plain strncture. Wings hyaline, a faint infuscation on the anterior apical part; posterior crossvein very oblique.

Femule.-Arista slender, about half the length of the body; bristles of posterior part of the thorax and scutellum of noticesble length, and those of front and middle tibia quite strikingly elongated ; fore metatarsus with distinct small bristles above; crossvein less oblique; otherwise as in male.

Isength $4-4.5 \mathrm{~mm}$.

Three males, six females, Florida (Lake Worth and Biscayne Bay), Mrs. Slosson ; Fla, and Lawrence, Kans., from the Univ. of Kans.

This species has a most remarkable resemblance to comatus, under which name I reported it to MIs. Slosson, but differs in larving small, dark (instead of large, pale yellow) appendages to the hypopygium, and in the absence of cilia the entire length of the middle tarsus.

The fentes of the two species are readily distinguished from all others at present kuown by the listinct row of hairs or small hristles on the upper side of the fore metatarsus; I have been unable to find any distinct character to separate them from each other.

\section{"silopodiums inperaton"s s. nov.}

Male-Face bright metallic, overlatid with silver pollen; antenna small. brownish black, almost destitute of bristles; front violet, thinly pollinose in a certain light, with pale hairs on the sides. Thorax green, the scutellum and part hefore it of a beantiful rosaceons, running into purple; plenre with pure white pollen; halteres moderately infusented; cilia of tegulæ pale on the lower half, blackish above. Abdomen slender, with rather long bristles; the basal three joints conspicuously marked with a non-metallic brown color, the incisures of the following part with moderate black bands; hypopygium small, ronnded, brownish hlack, with two slender, acnminate, brown organs projecting forward; venter brownish. Middle and hind coxæ brown; fore coxæ and all trochanters, femora and tibice yellow; hind knees slightly infuseated; fore tibia with only one or two minute bristles, fore metatarsus much longer than the tibia, with a few minute hairs below; middle tarsus once and a half as long as the tibia, infuscated from the middle of the first joint; hind tibia moderately hairg on the iuner side, on the outer with two small bristles; hind tarsi infuscated from the base. 
Wings large and broad, with the usual two crosslands. which are connected in front as fitr as the third vein, which curves broadly backward in the latter part of its consse, and then at the tip gently forward, in the manner typical of Agonosoma. Second posterior cell largely sublsyaline.

Length 8 mm.

One male, Rio de Janeiro, November (Dr: Williston).

This is the specimen referred to in Kans. Univ. Quart., II, 47, as heing intermediate between Guamptopsilopus and the restricted genus Psilopus. It has four large bristles on the scutellum.

\section{Psilopodiuns viridicoxa sp. nov.}

Strikingly similar throughout to scuber, but has the fore cosæ green, with yellow tip.

Face green, thinly white pollinose, anteunge black, small, with one or two rather noticeable bristles ahove on the second joint; front bright green, pollinose on the lower border, with a few pale hairs on the sides. Thorax bright green, the sides moderately pollinose; haiteres yellow. Abdomen green, with narrow black lands; hrpoprgium snall, black, with minute black ajpeudages. Front coxe green, the tips yellow, densely covered with white hair, and moderately pollinose with white; trochanters black, the fore ones somewhat rellowish; femora and tibire sellow; fore and niddle tarsi infuscated from the tip of the first joint, hind tarsi wholly infuseated ; fore tibia on the hind side with a row of five or six smallish bristles, ending before the tip. Fore tarsus once and a half the length of the tibia; the first joint has on the nuder side a row of fine hairs and a few scattered bristles; middle tibia with a row of close, erect hristles, some 30 in number, on the inner side in front; this row continues the greater part of the length of the metatarsus, and there are hesides a number of seattered small hairs on the under side of the metatarsus; hind tibia rather hairy, with three small bristles on the outer side. Wings with the usual two crossbands, which are narrower than in most species, and sometimes not very prominent; apex of wing largely hyaline.

Femole.-This sex has yellow fore coxæ, hence I am unable to find any available characters to separate it from scuber or sipho. I have many specimens of the three.

Length $6.4 \mathrm{~mm}$.

About 40 males, Opelousas, La., April and May (Dr. Hough).

Psilopodinus flavipes sp. nov.

Male.-Face pollinose with whitish, and bearing numerous pale hairs; antennæ black, with only one or two rather long bairs below on the second joint; front bright green. Thorax bright green, the sides thinly dusted with white pollen; halteres yellow. Abdomen bright green, with very narrow hands of black; hypopygium very small, almost entirely enclosed in the abdomen, but with a pointed end directed forward. Legs, except middle and hind coxæ and their trochanters, yellow; fore and middle tarsi infuscated from the tip of the first joint; hind tarsi and tips of the tibiæ infuscated. On the onter side of the hind tibia before the middle is a conspicuously long hristle; otherwise the legs do not show any characters of importance. Wings hyaline, venation as in caudatus.

Female.-Face with the same hairs; middle tibie with two or three scattered long bristles; fore tibia with a few smaller.

Length $3.6 \mathrm{~mm}$. 
Several specimens, Brookings, S. D., and New Bedford, Mass., the latter from Dr. Hough.

This species is almost identical with inermis Loew, except that the male has yellow femora, like the female.

\section{IGONOSOMA.}

Guérin-Ménevelle, Voyage sur la Cowette, 1838, 293.

Aldrich, Kans. Univ. Quart., I1, 48, 1893 (Gnamptopsilopus) ; Ca1. Ent., Aug.. 1904, 246.

\section{TABLE OF NORTH AMERICAN SPECIES.}

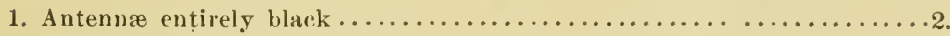

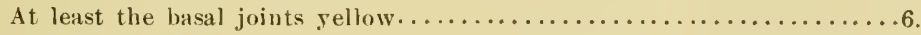

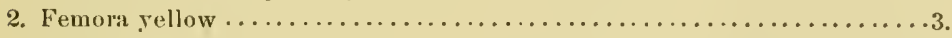

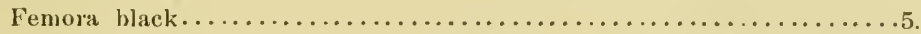

3. Fore coxæ with black bristles at tip (Mex.).....Infumatum Aldrich. Fore eoxæ with pale bristles at the tip $\ldots \ldots \ldots \ldots \ldots \ldots \ldots \ldots \ldots \ldots \ldots \ldots \ldots \ldots \ldots$.

4. Base of hind coxæ and hind margin of plenra pale (U. S.). costalis n. sp. Base of hind coxæ and hind margin of pleura dark (U. S.).

scintillans Loew.

5. Wings without black markings (Mex.)............eilipennis Aldrich. Wings black, except apex and hind margin (Mex.). . limidiatum Loew.

6. Dorsum of thorax yellow, with a green or blue stripe $\ldots \ldots \ldots \ldots \ldots .7$.

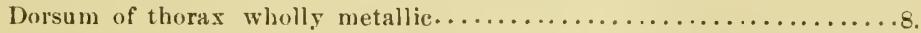

7. Plenra yellow; middle tibiæ and metatarsi with erect cilia (W. I.).

Pleura widum Aldrich.

Pleura with an indistinct dark spot; tarsi plain (W. I.)..dorsale Loew.

8. Thoracic dorsum opaque, dusted ; abdomen not pale at base (U. S.).

pallews Joew.

Thoracic dorsum shining, abdomen usually pale at base $\ldots \ldots \ldots \ldots \ldots \ldots$.

9. Middle coxæ infuscated on outer side at least to middle............

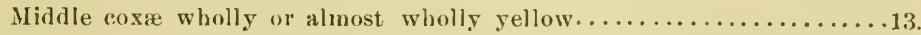

10. Costa of male ciliated, with an angular projection forward near the tip (U.S.).

psittacinum Loew.

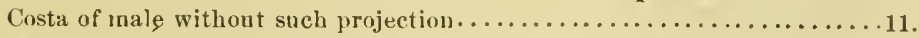

11. Mirllle femora of male shortened, dark at base, the tibix elongate (U. S.).

filipes Loew.

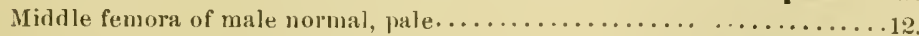

12. Abdomen pale at base above (U. S., Cuba) ......... variegatum Loew.

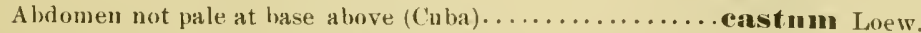

13. Fore femora with slender erect bristles helow (U. S.)........ remer Loew.

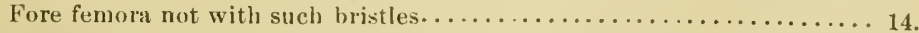

14. Hind margin of pleura yellow . . . . . . . . . . . . . . . . . . . . . . .

Hind margin of pleura green (Mex.)..........mexicamum Aldrich.

15. Abdomen above with basal yellow band, remainder green (U. S.).

(bicolor loew) nnifisciatum say.

Abdomen with several bands, including the greater part of first four segments (U. S.) ...........................

TRANS. AM. ENT. SOC. $\mathrm{XXX}$.

NOVEMBER, 1904. 
Agomosoma rotumaliceps sp. nov.

Male.-Face remarkabiy narrow, even the npjer part, white pollinose; palpi and proboscis pale sellow; antennæ small, rellow, tip of third joint infuseated ; front with considerable white pollen. Thorax green, not very brightly shining, with a brassy stripe ur mark on each side towarls the margin; tegulæe with their cilia, halteres and hind margin of the thorax pale sellow. Abdomen sellow, with green bands on the incisures, which are very narrow near the base, but widler towards the apex, the last two segments are wholly green; hypopsgium small, blackish, with two long, slender, yellow filaments. Legs, including coxæ, rellow. the tarsi moderately infuscated; middle tibiæ with quite noticeable minute bristles, part of which form a scattered row on the inner side; fore coxæ with rellow bristles at $t i p$, hind ones with a single llack one on the outer side. Wings hraline, costa not ciliated, third vein bicurved at tip.

Leigth $3.4 \mathrm{~mm}$.

A single male, Biscayne Bay, Fla., collected by Mrs. Annie T. Ṡlosson.

This species must be nearly related to flavicomis, described by me from St. Vincent, W. I. That species is known only in the female sex, and the types are not accesible, being in London. The species here described seems to have much more yellow on the abdomen, and the bristles of the mildle tibire constitute an important distinetion.

The roundness of the head is very noticeable from in front.

\section{Agouosouna costale sp. nov.}

Male.-Fuce and lower part of the front with thin golden pollen, not visible, except in all oblique view; with a side light, however, two round spots above the antenuæ may be observed in a direct view. Antenna black, small; cilia of the inferior orbit pale sellow. Dorsum of thorax bright green, the pleuræ a little pollinose with white; posterior edge of the pleuræ, the halteres aud tegulæ, and the tegular cilia, yellow. Abdomen grcen, with a sencely perceptible brownish rellow dust on the latter part; first segment with a yellow crescent above, and the venter yellow on its basal third; hypopygium minute, embedded, only a pair of minute dark aplendages visible. Fore and hind coxæ rellow, middle ones infuscated more than half the leugth; femora and tibia sellow, the fore tibia with no bristles, except a minute one uear the base on the outer side ; tarsi plain, infuscated from the latter part of the first joint. Wings with a rellowish tinge, the costa somewhat thickened and ciliated to the end of the second vein with close, stout, erect cilia, which do not decrease in size, but are rather large towards the end. There is a peculiar and very conspicuous crook in the costa hefore the end of the second vein, making a notch in the wing, in which are several much longer hairs, standing at an angle with the surface of the wing. The segment of the fourtl vein from the hind crossvein to the fork is more than double the length of that from the fork to the margin.

Female.-Costa entirely destitnte of any cilia; pollen of front yellow, but very diflicult to perceive, that of the face also vers indistinct, but more whitish.

Length 3-4 mus.

One male, two females, Tifton, Ga., June 8 and 11, 1896 ; collected by I)r. (iarry de N. Hough. 






\title{
THE DIP'TEIROUS GENERA TATH'TRECHUS A ID VICELLOCEIRUS.
}

\author{
BY J. II. ALDRICH.
}

This group of the Dolichopodidie containerl, at the time of Loew's monograph, one genus and three species. Since then Loew published another species in his seventh Century, and Osten Sacken one in "Western Diptera." Mik has established a new genus for a part of the old one, and three new species are described in the present paper.

These two genera form a well-clefined group, with the following characters: First antenual joint hairy above, arista dorsal, face long, narrow, wider below and rounded at the tip, reaching as low as the inferior border of the eye; wings narrow, in the male espepecially ; hypopygium of the male entirely disengager, directel forward under the venter, reaching nearly to the coxis hind metatarsi without bristles above.

The genera are separated by the following characters:

Male antenuæ normal, like those of the female; fourth longitudinal vein ending just before the extreme apex, at a considerable distance from the tip of the

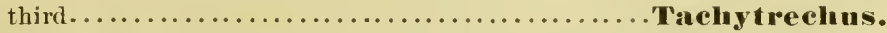

Male antennæ with the second joint rudimentary and the arista elougated and ending in a lamella; fourth vein ending considerably hefore the apex, very

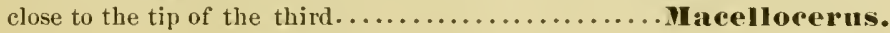

Tachytrechus Loew.

Stannius isis 1831, p. 261, Loew, Neue Beitraege, v, 1857; Mon. Dolichopodidre, p. 109.

MALES.

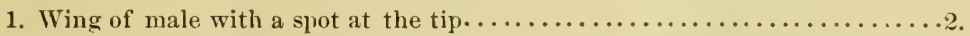
Wing of male without spot..................ngustipenuis Loew.

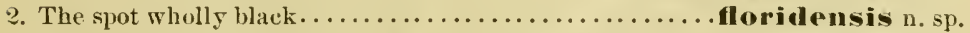
The spot black in front, snow-white behind............. vorax Loew.

\section{FEMALES.}

Posterior femora yellow at the extreme tip only................. vorax. Posterior femora abont a third of the length yellow........... floridensis. (The fenule of anyustipenuis is not known.) 
Tachytrechus floridensis 11 . sp.

Male.-Front green, heavily coated with whitish dust, face wholly pure white, abont twice as wide on the lower division as imnediately helow the antennæ, palyi inconspicuous. proboseis black, inferior and lateral orbital cilia white; antenna wholly black, the first two joints a little elongate, slender, the thirt rounded, the arista a trifle longer than the three joints. Thorax green, heavily coated with whitish dust, which leaves the ground-color more distinetly visible in some directions than in others; plente with a more pure white dust, the green showing through; tegula and halteres yellow, the former with small black cilia; coxat and basal two-thirds of femora green, overlaik with white dust, the tips of all the femora for a third thrij length (in the midale ones more) yellow, tibixe yellow with black tips, tarsi black, the front ones four-fifths the length of the tibice; fore tihice with only two series of bristles, three or four in each, the one behind and a little towards the outside, the other opposite in front; hind femora witl a row of three bristles before the preapical one. Abdomen of the same color as the thorax, more shining on the posterior part of each seguent across the middle, with a rather strong row of hairs hefore each ineisure - these and all the small hairs black ; hypopsginm black, the first joint, or pedicel, small; the second large, massive, sub-ylobular, with whitish dust and fine black bairs; lamella blackish, snall, somewhat triangular, with a narrow base, the onter edge of each bearing a number of long black bristles extending laterally. W'ings slight Iy grayish, narrow, pointed, with a large black dot in the apex, nearly the whole of which is behind the fourth rein; third vein almost straight in its whole course, with only a slight and nearly muiform curvature; large eross-vein guite obligue, straight. less than its leugth from the tip of the fif th vein : last segment of fourth vein straight, only a vers little convergent towards the third, ending conspicnously before the apex of the wing.

Female.-Wings scarcely so marrow, withont dot, antemse a little shorter, face a trifle wider. On the outer side of the fore tibize there are one or two sma? 1 bristles in a third series. Length $5 \mathrm{~mm}$.; of wing $4 \mathrm{~mm}$.

Two males, two females, Florida. Collected by Chancellor F. H. Snow. I obtained the specimens from the University of Kansas, and there are several more in their collection.

Tachytrechus vorax Loew, Nene Beitraege, viii, 41 ; Mon. Dolichopodidre, 112. Distriet of Columbia.

I have specimens from Brookings, S. D.; Hot Springs, S. D. (in the Black Hills); Jackson, Miss. (C. W. Johnson); and Franeonia, N. H. (Mrs. Slosson).

Tachytrechums angustipenu is Isoew, Centuries, ii, 64; Monograph Doliehopodida, 113. District of Columbia; Osten Sacken, Western Diptera, 315, California.

I have not seen this species. 


\title{
Macellocerus Mik.
}

Mik, Dipterologisehe Untersuchungen, p. 3, 1878.

\author{
MALES.
}

1. Antenual arista with a lamella in the midnle as well as at the tip.

binodatus Loew.

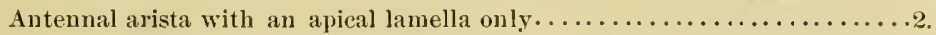

2. Anterior femora thickened, black below on the basal half...olympige n. s]).

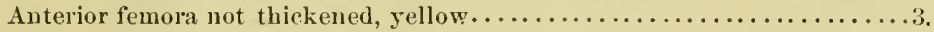

3. Outer side of fore femora with long, curly hair............ auratus n. sp.

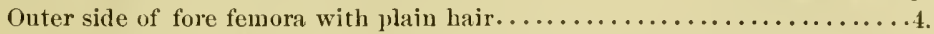

4. Anterior tibiæe with a row of ereet, flattened bristles on the outside below.

saums $O$. S. Anterior tibiæ with only a few common bristles on this part. .moechus Loew.

\section{FEMALES.}

1. Hind femora yellow, two preapical bristles.................. auratus.

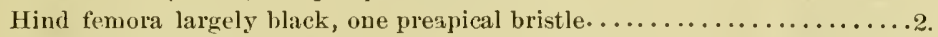

2. Front tihire wholly yellow. . . . . . . . . . . . . . . . . . . nuochus. Front tihiæ largely black. . . . . . . . . . . . . . . . . . . . . . . .

3. Four anterior femora green-black, the apjeal third yellow. distinctly limited.

sallus.

Four anterior femora largely yellow, the brown at base not distinctly limited.

(The female of binodatus is unknown)

olympiae.

\section{IIacellocerus olympiae n. sp.}

Mule.-Face long, bright yellow, slender ju the middle; antennæ yellow, the third joint blackened except at base, second joint rudimentary; arista one and a third times as long as the vertical diameter of the head, white except the incrassated base and the obovate black lamella, which is a little smaller than the third joint; lateral and inferior orbital cilia light yellow. Thoras and abdomen bronze-green; tegulæ yellow, with black cilia; fore coxæ yellow, bare except the tip. Fore femora incrassated at the base, with a peculiar cireular black spot seemingly stamped upon the onter side, reaching beyoud the middle; the inner side is pellow, with a delicate pruinosity ; fore tibiæ yellow, with namerous and rather long bristles; fore tarsi a little compressed. short, black; posterior femora aud tibia yellow, tips of the lattex narrowly blackened, tarsi black; bristles of the tibiæ rather long. Hypopygium large, basal part shining black, central segment bronze-green behind, lamelle whitish, covered with black hairs, those of the margin hardly coarser. Wings exceedingly slender, grayish, lighter at the root.

Femule.-All the body color darker, face wider and greenish yellow, third joint of the antennæ black, all the coxæ black, femora more or less dark on the basal part, the hind oues wholly black-green except the apical third; tibia black on the apical third or fourth. Wings longes and much wider than in the male. Length $6 \mathrm{~mm}$.; of wing $4.2 \mathrm{~mm}$.

Two males, two females, Olynupia, Wash. (Trevor Kincaid), June 3 and July 1.

\section{Macellocerus anratus n. sp.}

Male.-Face long, golden-yellow, very narrow in the middle, antenne bright yellow, small, the second and third joints both very minute and rudinentars. arista black, one and a half times the length of vertical diameter of the eye, the 
obovate lamella black, as large as the three antennal joints together, with a very small white portion at the base: cilia of the lateral and inferior orbit white. Thorax and abdomen bronze-green, somewhat obsenred in parts by greenish white pollen; the groove above the root of the wing velvet-black; second and third segments of the aldomen, with the central part of the hypolyginm, having a copyery luster; tegular eilia black; lower part of the pleure with thin golden pollen, which trecomes thicker near the coxa and extends down the outside of the middle ones: fore coxæ and legs rellow, the former with a golden luster: the fore feet compressed, a little infuscated, with a satiny white reflection : on the onter side of the femora the hairs are fine and long and curly ; the fore tibire are a little enlarged beyond their base and bave two rows of slender bristles, those in the postero-lateral row are slightly flattened; posterior femora and tihix yellow, the latter tipped with black; middle tarsi a little pale at base, the rest black, hind ones black; middle femora with conspieuous long hairs before along the lower part; the same but in a less degree on the hind femora; lamella of the hypopygium whitish, small, with only small hairs. Wings short, morlerately narrow, gray, sellowish at base.

Female.-Face whitish, wider, antennæ very short, third joint bat slightly infuscated : fore tibiæ infuscdted towards the tip. Legs with ordinary, hut rather long bristles, two preapical bristles on hind femora (as in the male also), body color a little darker than in the male. Iength $4.7 \mathrm{~mm}$.; of wing $3.2 \mathrm{~mm}$.

One male, two females, Moscow, Idabo, June 18. On moist sand at edge of mountain brook.

Macelloeerus moechus Loew, Nene Beitraege, viii, 40; Mon. Dolichopodidæ. 110 (Tuchytrechuss). Trenton Falls, N. Y

I have one male, Algonquin, Ill. (Dr. Nason, and one female, Franconia, N. H. (Mrs. Slosson).

Macel locerus sanus Osten Sacken, "Western Diptera," 316 (Tachytrechus). California.

I have numerous specinens, Craig's Mountain, Nez Perces County, Idaho, June 22 and 26, and Moscow, Idaho, June 18 and 25 . Most of these were collected on fallen logs about the edges of a little damp meadow; others were taken at the edge of mountain streams on moist sand. 






\section{THE}

\section{KANSAS UNIVERSITY SCIENCE BULLETIN.}

(Vol. I, No. 3-March, 1902. Whole Series, Vol. XI, No. 3.)

CONTENTS:

Dolichopodid.e of Grenada, W. I., . . . . . J. M. Aldrich.

PUBLISHED BY THE UNIVERSITY,

LAWRENCE, KaN.

Price of this number, 30 cents.

Entered at the post-office in Lawrence as second-class matter. 



\title{
KANSAS \\ LNIVERSITIY SCIENCER \\ BLLLE'TIN.
}

Vol. I, No. 3.

MARCH, 1902.

\} WHOLE SERIES, Y VOL. XI, NO. 3.'

\section{DOLICHOPODIDÆ OF GRENADA, W, I.}

\author{
BY J. M. ALDRICH.
}

THIS family is represented by fifty-five species, of which fourteen are herein described as new, and twenty-seven were described in my previous paper on the Diptera of St. Vincent. Twelve species in the lot from St. Vincent were not found in this collection. Only one of these was known prior to the publication of the St. Vincent paper.

I have made a consolidated list of the Dolichopodidæ of these two islands for comparison of their fauna. $V$, after the species, indicates its occurrence on St. Tincent; G., on Grenada. ${ }^{1}$ A star indicates that the species was previously known. All unstar"ed are described in the two papers. New genera are indicated.

\section{List of Dolichopodide from St. Vincent and Grenada.}

GyMNOPTERNUS. ruficornis. $\mathrm{V}$.

Pelastoneurt's. argentiferus. V.G. unguiculatus. $\mathrm{V}$.

Paraclies.

nigripes. G.

fuscicornis. G. discifer. G.
Paraclics.

quadrinotatus. G.

* renustus. $\mathrm{G}$.

bellus. G.

filiferus. V. G.

abdominalis. G.

*arcuatus. G.

* claviculatus. G.

${ }^{1}$ Note.-Grenada and St. Vincent are two small islands of the Windward group of the Lesser Antilles, distant, respectively, about 75 and 150 miles from the Venezuela coast. Extensive collections were made in the two islands a few years ago, by Mr. H. H. Smith, for the Entomological Society of London. The material from St. Vincent was worked up by Dr. S. W. Williston, except the families Dolichopodiclce and Phoride, which were undertaken by me, at Doctor Williston's request. The report was published in Trans. Ent. Soc. Lond., 1896, pp. 253-446, 7 pl. It was intended that the Grenada material should be published in the same way, and the present paper was prepared some time ago; but pressure of work has prevented the completion of the report on the other families, and it has been thought best not to delay the publication of the present paper any longer. 


\section{List of Dolichopodida from St. Vincent and Grenada.}

\section{Sarcionus.}

lineatus. V. G.

Hercostom us. latipes. V.G.

Polymedon. superbus. V.

Nevrigona. decora. G. signifera. V.G.

ANEPSIUS.

linearis. V. G.

Sympyonus.

frater. G.

falco. V. G.

similis. V. G.

Leptocorypha, n. gen. pavo. V.

Eutarsus. sinuatus. V. G.

Diaphorus. amcenus. G. dimidiatus. V. G. flavipes. V. G. contiguus. V. G. simplex. V. G. dubius. V. G.

* opacus. V. G.

* spectabilis. V. G. parvulus. V.

Asrndetus.

* syntormoides. G. fratellus. V. G.

Chrysotus. paradoxus. G. albipalpus. V. G. niger. V. G. excisus. V.G. hirsutus. V. G.
Chrysotus.

longipalpus. V. G. proximus. V. G.

flavus. $Y$.

acutus. V. inermis. $\mathrm{V}$.

* picticornis. V. G.

* barbatus. V. G.

Thrypticus. cupuliferus. V. G. minor. V. G. singularis. $V$.

Achalcus. caudatus. G. sordidus. V. G.

Xanthina, n. gen. plumicauda. G.

Thinophilus. sp. $G$.

Ceeloglutus, n. gen. concavus. $\mathrm{V}$.

Medeterus. exiguus. G.

Plagioneurus.

* univittatus. G.

Leptorhethum, n. gen. angustatum. V.

Psilopus. bellulus. V. G.

* jucundus. G.

* chrysoprasius. V. G.

* caudatulus. V. G. insularis. V. G.

Gnamptopsilopus. flavicornis. V. G. flavidus. V. G.

* bicolor. V.

The most striking things about the table are the preponderance of Paractius in Grenada, near the mainland, and the larger number of new genera in St. Vincent, farther off shore.

The mounting of these collections is exceptionally fine, and deserves mention. Out of several hundred cases where a male and a female were mounted on the same pin, there was only one where they were not of the same species. This is an astonishing fact-a record to be proud of, considering that the collecting was general and these species all minute. 


\section{PARACLIUS.}

Loew, Monogr., 97, 1864 (non Bigot).

The relationships of Paraclius, Pelastoneurus and Sarcionus are somewhat puzzling. I have considered as belonging to $P c$ lastoneurus those species only which have the face broad in both sexes, with a slight concavity in the upper part and a marked convexity below. The arista is distinctly plumose. The fourth vein in its last part converges toward the third with more or less abruptness, but I do not regard this as the essential character. Sarcionus includes species with narrow face, comprising in the male about a tenth the width of the head; it is but little, if any, convex below; the arista is plumose. In the female the face is about a sixth the width of the head, and has more resemblance to that of Pelastoneurus. The fourth vein converges strongly toward the third in the latter part of its course. In Paraclius the face is like Sarcionus, but the arista is bare or only moderately pubescent. The fourth vein near its end makes a somewhat sudden curve toward the third, then gradually resumes its former course, forming a curve with its concavity outward; this is quite variable in shape, and in at least one species there is no marked concavity, as in Pelastoneurus vagans. The characters of the face and arista seem most substantial.

Table of North Ameriean and West Indian Species of Paraclius.

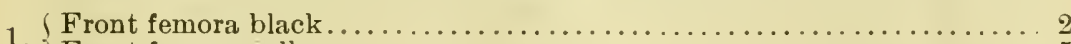

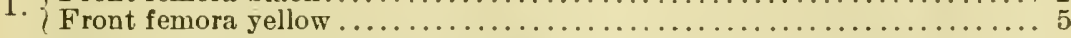

6) \{ Tibiæ all black, costa not thickenęd............... nigripes, n. sp.

$\{$ Tibire not all black, or else costa conspicuously thickened............ 3

(First section of costa greatly thickened in male, mod-

3. erately in female............................ albonotatus Loew. First section of costa not thickened........................... 4

4. $\{$ Hind tibia yellow ........................ fuscicornis, $\mathrm{n} . \mathrm{sp}$.

4. $\{$ Hind tibiæ mostly black....................... pumilio Loew.

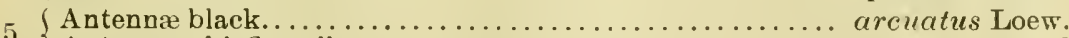
- $\{$ Antennæ chiefly yellow................................... 6

6. $\{$ Arista in the male enlarged at tip, disk-like................ 7

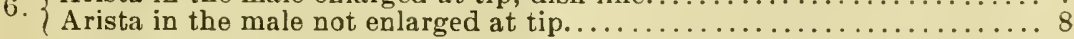

7. $\{$ Arista long, tapering, thin.......................... discifer, n.

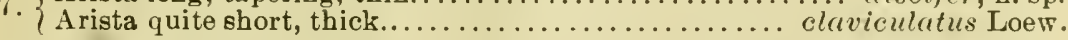

8. $\{$ Two velvet-black spots between the root of the wing

8. $\{$ and the humerus........................ quadrinotatus, $\mathrm{n} . \mathrm{sp}$.

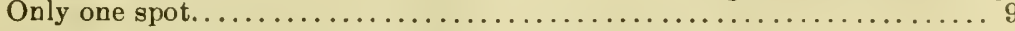

(Dorsum of thorax wholly deep green on anterior part.............. 10

9. Dorsum of thorax with a bronze stripe between acrostichal

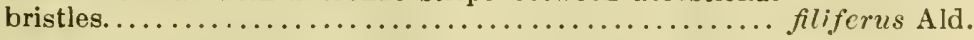

10. $\left\{\begin{array}{c}\text { The curve of fourth vein occurs half-way between the pos- } \\ \text { terior cross-vein }\end{array}\right.$

The curre ocs-vein and the apex.................... venustus, $\mathrm{n} . \mathrm{sp}$. 
Paraclius nigripes, n. sp.

Male: Face with dense whitish dust, rather wide in the lowest part, antennie of ordinary size, wholly black, arista bare, front with gray dust, orbital cilia, except a few above, snowwhite. Thorax steel-blue above; the same color overlaid with thin white dust on the pleuræ. Halteres yellow, tegulie whitish, with black cilia. Abdomen dark blue-green, rather dull, with some white dust along the sides; hypopygium large, the appendages small, brown; the lamellie are only rudimentary. Legs altogether greenish black, with thin white dust, from the knees down less green. Fore tarsus as long as its tibia; hind metatarsus as long as the next joint. Wings narrow, infuscated except at base, the fourth vein ending considerably before the apex, only a little recurved near the tip.

Female: Face but little wider, wings less infuscated.

Length, 3.5 to $3.8 \mathrm{~mm}$; of wing, $2.5 \mathrm{~mm}$. Five males, five females. The shape of the face and the venation are strikingly like the genus Macellocerus. The head is not nearly so lengthened vertically, however, as in that genus. It must be regarded as a connecting link between the two genera.

\section{Paraclius abdominalis, $\mathrm{n}$. sp.}

Male: Face moderately narrow, extending down to the lower edge of the eye, white on its lower two-thirds, somewhat brownish above; front covered with white pollen, except the ocellar triangle and the root of the large vertical bristles; antennæ black, of moderate size, with plain, tapering arista; orbital bristles white, except about one-third of them on the upper part. Thorax bright, shining bluish green above, very slightly inclined towards violet posteriorly; a broad, black, velvet-like spot above and before the root of the wing; a small, yellow spot just over the humeral spiracle; pleuræe black, thinly dusted with pale gray or whitish; halteres and tegulæ yellow, cilia of the latter black. Abdomen crossed with nearly equal bands of green and violet, the latter occupying the last half of each segment; the green bands are covered with white dust on the sides, and gradually widened; hypopygium thick, large, black, with small, short lamellæ of a sordid white color, black on the edges, and bearing some stout curved hairs on the free basal angle, which is prominent. Legs black, the tips of 
all coxæ, the trochanters, extreme tips of femora, all the tibiæ and the bases of all tarsi yellow. Wings subhyaline, only faint traces of brown along the veins; the bend of the fourth vein occurs just past the middle of the last section, and is quite abrupt; the curve back towards its former course is also rather short, so that the rein is nearly parallel with the third for some distance at the end; costa with a long and striking swelling, beginning just after the humeral cross-vein, and continuing almost to the tip of the first longitudinal. Length, $4.4 \mathrm{~mm}$.

Female: Face as in male; front with pollen a little grayish; abdomen with same bands; thickening of costa perceptible.

Length, $4.2 \mathrm{~mm}$. Four males, two females. The following label on one: "Lights generally on stones in streams; commonly seen in pairs, the two sexes lighting near to each other; very wary, and difficult to capture."

The species is closely related to albonotatus Loew, but the latter has darker wings, third and fourth veins convergent to the tips, swelling of costa larger in female, etc.

\section{Paraclius fuscicornis, n. sp.}

Male: Face very narrow in the middle, with brownish pollen, sometimes more whitish; antennæ varying from light to dark brown, of ordinary structure; front with light brown dust. Cilia of lateral and inferior orbit white. Thorax deep blue, varying to purple, shining; pleuræ with thin whitish dust; halteres yellow; tegulie yellow, their cilia black, abdomen shining blue, the posterior margins of the segments deep purple in the best-developed specimens, the sides of the segments with white dust; hypopygium large, thick, the lamellæ short, brown. Coxæ and tarsi black; the trochanters, knees and tibiæ yellow. The femora are not so dark as in the related species, more deep brown than black. Wings rather slender, slightly infuscated, bend of fourth vein midway between great cross-vein and apex, last part of fourth parallel with third. Costa not thickened.

Female: Face a little wider than in male.

Length, 3.5 to $4.3 \mathrm{~mm}$. ; of wing, 3.3 to $4 \mathrm{~mm}$. Five males, five females, one bearing label: "Balthazar (Windward), 250 feet, April 7. Lighting on stones in bed of shady stream." 


\section{Paraclius arcuatus.}

Loew, Neue Beitr., VIII, 39; Monogr., 101.

Twenty-three specimens, both sexes, one labeled: "Lights on wet mud, generally near water."

These specimens differ quite materially from Loew's description in having the fore coxie scarcely infuscated at base, hind femora only a little infuscated toward the tip, hind tibire yellow except the tip, and the wings only a little brownish; in other words, a light variety as compared with the types. I should have regarded these as a distinct species had I not the undoubted arcuatus from Jamaica (by the kindness of Mr. C. W. Johnson) for comparison.

Paraclius discifer, n. sp.

Male: Face moderately wide, with silvery dust; front bright green; antennæ yellow, third joint slightly infuscated at tip, with arista a little longer than the front femur, thick at base, very slender toward the tip and ending in a small oval lamella, just large enough to be visible to the naked eye when held against a white background. Lateral and inferior orbital cilia white. Thorax bright green, a little dusted, the space between the acrostichal bristles, and a roundish spot on each side above the transverse suture, bronze; pleurie rather dark with gray dust, halteres and tegulæ yellow, cilia of the latter black. Abdomen bright green, but little dusted; hypopygium large, somewhat greenish, the lamella brown, with a long upper corner curving backward, so that they might be called crescentshaped, attached by the lower angle. Front coxæ yellow, the others infuscated; femora and tibix yellow; all the hairs infuscated from the tip of first joint. Wings subhyaline, the posterior cross-vein forming a right angle with the axis of the wing, the curve of the fourth vein half way from the cross-vein to the tip, making a very obtuse angle. Third and fourth veins parallel at the apex for a short distance.

Female: Face a litle wider, arista normal, with moderate pubesence. Thorax without the bronze spots.

Length, $3 \mathrm{~mm}$. One male, one female. 


\section{Paraclius claviculatus.}

Loew, Centuries, VII, 83.

Two males. The arista is rather thick, two-thirds the length of the front femur; the wings are infuscated and the dorsum darker in one specimen. There is a very close relation with discifer, yet they are undoubtedly distinct.

\section{Paraclius quadrinotatus, n. sp.}

Male: Face moderately wide, the pollen whitish gray; front with brownish pollen; antennæe red, of ordinary appearance, the arista slightly pubescent, cilia of the lateral and inferior orbit white, thorax above somewhat mottled; when viewed from the side, the light coming from above, there is a large, velvet-black spot above the root of the wing and another still larger in the transverse suture. These are separated from each other by a narrow metallic area, and present a very distinctive appearance. Pleurie black, with gray dust, tegulie and halteres yellow; tegular cilia black. Abdomen green, the segments dusted with white on the sides; hypopygium of moderate size, the lamellæ small, black, triangular. Fore coxi yellow, the others brown; femora, tibize and first joint of tarsi yellow ; tips of tarsi moderately infuscated. Wings more or less infuscated on the costal part, usually but little; curve of fourth vein more than half way from cross-vein to apex, not at all angular, the return curve just before the tip of the same shape reversed.

Female: Differs only in having the face a little wider.

Length, $2.4 \mathrm{~mm}$.; of wing, $2.2 \mathrm{~mm}$. Twenty-five specimens.

\section{Paraclius filiferus.}

Aldrich, Trans. Lond. Entom. Soc., 1896, 314.

Numerous specimens.

\section{Paraclius venustus.}

Aldrich, Biologia. Diptera, Supplement.

Numerous specimens.

\section{Paraclius bellus, n. sp.}

Male: Face narrow, silvery; front green, antennæ red; the arista slightly pubescent; cilia of the lateral and inferior orbit white. Thorax dark blue, shining; the silvery spot on each side at the suture rather large; pleura rather heavily coated with 
bluish-white dust; halteres and tegulæ yellow; cilia of the latter black. Abdomen with a ringed appearance, the anterior half of each segment bright green, on the sides whitishdusted, the posterior half blackish, dull; hypopygium large, whitish-dusted; the lamellae very small, yellow, with the apical third blackish. Front coxæ and the tips of the others yellow; femora and tibice yellow, fore tarsi infuscated at the tip only, middle ones from the tip of the first joint, hind ones from the base; hind femora and tibire both distinctly darkened at the apex. Wings with a yellowish tinge, the fourth vein bent forward near its tip and thence nearly straight, as in Pelastoneurus. The hind femora have a row of bristles above of which the last four or five toward the end are quite conspicuous.

Length, 3.1 to $3.6 \mathrm{~mm}$. Four males, seven females.

\section{PELASTONEURUS.}

Loew, Neue Beitr., VIII, 36, 1861; Monogr., 103.

Pelastoneurus argentiferus.

Aldrich, Trans. Lond. Entom. Soc., 1896, 313.

Thirty-five specimens, both sexes.

\section{SARCIONUS.}

Aldrich, Biologia, Dipt., Suppl, 1902.

Sarcionus lineatus.

Aldrich, Trans. Lond. Entom. Soc., 1896, 312 (Pelastoneurus).

Numerous specimens, both sexes. The width of the face in the male is one-twelfth, in the female one-sixth, the width of the head; therefore the species cannot be a Pelastoneurus.

\section{HERCOSTOMUS.}

Loew, Neue Beitr., V, 9, 1857.

\section{Hercostomus latipes.}

Aldrich, Trans. Lond. Entom. Soc., 1896, 311.

Numerous specimens, both sexes.

\section{NEURIGONA.}

Rondani, Prod. Dipt. Ital., 142, 1856.

Neurigona signifera.

Aldrich, Trans. Lond. Entom. Soc., 1896, 337.

One male. 
Neurigona decora, n. sp.

Male: Eyes barely contiguous on the upper part of the face, slightly separated above and below ; front broad, opaque, dark ; antennæe small, red, the tip of the third joint brownish ; orbital cilia pale. Thorax bright, shining blue, the concavity before the scutellum more bronze; pleurie green, with thin dust, and the hind margin yellow; tegular cilia yellowish. Abdomen rather short, the first two joints yellow, the rest dark green, shining above. Hypopygium rather prominent, exserted, yellow. Coxae yellow, the middle ones dark at base; remainder of legs and the tar'si yellow; a slender hair on the outer side of the second joint of the fore tarsus at its apex. Wings a little yellowish; the fourth vein converges toward the third at the end, terminating before the apex of the wing.

Female: Face linear ; eyes not contiguous.

Length, 2.8 to $3 \mathrm{~mm}$. Two males, two females. One of the latter is from St. Vincent, but was not mentioned in the previous paper.

Anepsius linearis.

Aldrich, Trans. Lond. Entom. Soc., 1896, 317.

Nineteen specimens.

Eutarsus sinuatus.

Aldrich, Trans. Lond. Entom. Soc., 1896, 334.

Nineteen specimens.

\section{PLAGIONEURUS.}

Loew, Wien Ent. Monatsch., I, 43.

Plagioneurus univittatus.

Loew, loc. cit.; Neue Beitr., VIII, 69; Monogr., 196.

Williston, Trans, Amer. Ent. Soc., XIII, 295.

One female. This species has a very striking distribution, considering that it is everywhere uncommon. It is found from Brazil as far north as South Dakota, and east to Massachusetts.

\section{SYMPYONUS.}

Loew, Nene Beitr., V, 42, 1857 ; Monogr., 185.

Sympyonus frater, n. sp.

Male: Front blackish with gray dust; face narrow below, of the same color; antennæe of moderate length, first two joints 
yellow, the third black, rather pointed, arista inserted near the base; palpi rather pointed, yellow; occiput with gray dust, the orbital bristles small, at the sides and below whitish. Thorax dark green above, with thin dust and rather large bristles; pleur: black, with dense, almost white, dust; tegular cilia dark, in some lights almost russet, in others blackish; halteres yellow; abdomen not elongated, scarcely equaling the head and thorax in length, not compressed, dull green in color, with row of longer hairs at the margin of each segment; hypopygium black, thick, rounded, protruding behind and below on the ventral side, making up nearly half the length of the abdomen, with some partially concealed slender yellow parts at the front end. Middle coxie infuscated on the outer side, the other coxre and all the feet yellow; the tarsi scarcely infuscated; fore tarsi as long as the tibia, the last three joints of equal length, the fifth black, the inner claw stout, black, curved back upon the joint to form a clasping organ, very much as in $S$. falco; the outer claw normal. On the front side of the hind femur below is a row of black bristles, longer toward the tip; wings grayish, the last section of the fourth vein almost perfectly straight, the third converging toward it at tip.

Female: Like the male, but the face not narrowed below; the fore tarsi normal; no bristles on hind tibix.

Length, 2.2 to $2.4 \mathrm{~mm}$.; of wing, $2 \mathrm{~mm}$. Numerous specimens, both sexes. This species, with falco and similis and the Mexican coralis, forms a group of close relationship, yet sufficiently distinct from each other.

\section{Sympyonus falco.}

Aldrich, Trans. Lond. Entom. Soc., 1896, 336.

Two females. The black antenne and plain fore tibiæe sufficiently distinguish the females from those of the related species.

\section{Sympyonus similis.}

Aldrich, Trans. Lond. Entom. Soc., 1896, 336.

Two males, two females. The row of bristles on the fore tibia occur's also in the female, making an easy distinguishing mark. 


\section{DIAPHORUS.}

Meigen, Syst. Beschr., IV, 1824.

Loew, Mon. N. A. Dipt., II, 156, 1864.

In attempting to separate this genus from Chrysotus, which it of ten greatly resembles, I have followed these rules: First, to assign to Chrysotus all species in which the eyes of the male are approximated below the antenna, and to Diaphoms all in which they are approximated above; second, of the considerable number of species in which there is no approximation, to refer to Chrysotus all in which the male does not have a group of large bristles at the apex of the abdomen.

In my preceding paper on the Dolichopodidæ of St. Vincent, I made a bad blunder in failing to recognize Diaphorus spectabilis Loew, which I redescribed as $D$. approximatus. I have since found further that the numerous females which would almost inevitably accompany "numerous males" in a collection were mixed up with the females of Lyroneurus simplex Ald., and they are there yet, as I am unable to find any characters for their separation. The two species being nearly, if not entirely, indistinguishable in the female sex, it seems evident that the genus Lyroneurus is insufficiently characterized, and I have accordingly abandoned it. Loew himself (Mon. N. A. Dipt., II, 169) was a little staggered when he came to compare the genus with some North American species of Diaplorus; but with the material then known it still seemed tenable. It would certainly be an anomaly, however, if two females not distinguishable from each other would have to be placed in separate genera.

\section{Table of West Indian Species of Diaphorus.}

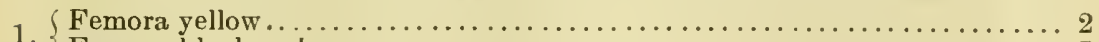

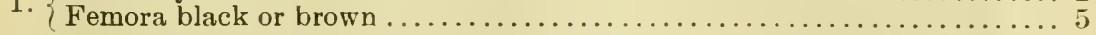

9. Fore coxæ with a row of three long bristles............ dimidiatus Ald.

2. $\{$ Fore coxæ with only small bristles. . . . . . . . . . . . . . . . . . . . . 3

3. Male with very large pendent white palpi.............. amcenus, $\mathrm{n} . \mathrm{sp}$.

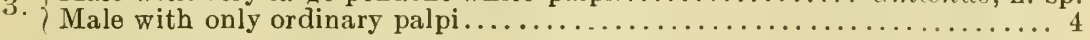

Eyes of male not approximated. $\ldots \ldots \ldots \ldots \ldots \ldots \ldots \ldots$ parvulus Ald.

4. $\{$ Eyes of male approximated, tarsi infuscated (Cuba)... subse junctus Loew. (Eyes of male contiguous, tarsi not or scarcely infuscated...... flavipes Ald.

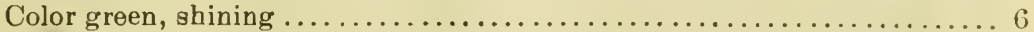

Color black, but little shining, wings deeply infuseated..... opacus Loew.

5. Color black, dorsum gray pollinose, opaque, wings but little

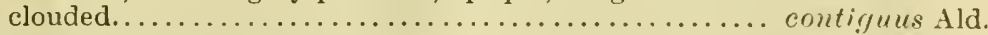

6. Eyes of male approximated.................. spectabilis Loew.

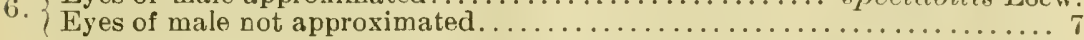

Male with a long erect bristle on the under side of the hind

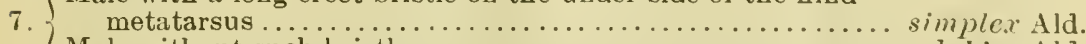
Male without such bristle ........................ dubius Ald.

(Parvulus and subsejunctus are not represented.) 


\section{Diaphorus dimidiatus.}

Aldrich, Trans. Lond. Entom. Soc., 1896, 322.

Thirteen males, four females. The latter are readily distinguishable by the bristles of the fore coxæ, although they do not have the yellow color on the abdomen that characterizes the males.

\section{Diaphorus amœnus, n. sp.}

Male: Face rather wide, green, in an oblique direction yellow pollinose; front wide, bright green; antennie black, the first joint slightly elongate, third pointed, arista completely apical; palpi very large, yellowish white, hanging down about a third the height of the head, about two-thirds as wide as long; cilia of inferior orbit white; thorax and abdomen bright green abore, somewhat golden, the former a little dusted; pleuræ blackish green, sliglitly pruinose with white; tegular cilia few, yellowish white; halteres yellow, abdomen slender, the bristles at apex distinct; fore coxæ yellow, the others brown; femora and tibire yellow, the hind femora slightly infuscated at tip; fore and middle tarsi slightly exceeding their tibire in length; all tarsi gradually infuscated toward the tip; front pulvilli elongated, the others also a little conspicuous; wings of medium size, tinged with gray.

Female: The only female I have is almost exactly like that of flavipes. The antenna being more distinctly black, and the coxæ with noticeably longer and more numerous brown hairs, are the only differences I can detect. The male amenus has but a few long, brownish hairs in a row down the fore coxre.

Length, $2.5 \mathrm{~mm}$.; of wing, $2 \mathrm{~mm}$. Three males, one female.

\section{Diaphorus flavipes.}

Aldrich, Trans. Lond. Entom. Soc., 1896, 323.

Numerous males and females.

\section{Diaphorus opacus.}

Loew, Neue Beitr., VIII, 56; Mon. N. A. Dipt., II, 160.

Aldrich, Trans. Lond. Entom. Soc., 1896, 320.

Six males. A comparison with specimens from the United States establishes their identity, as also that of the St. Vincent specimens referred to in the previous article.

Lengtl of the present specimens, $2.8 \mathrm{~mm}$. 


\section{Diaphorus contiguus.}

Aldrich, Trans. Lond. Entom. Soc., 1896, 323.

Eight males, three females.

\section{Diaphorus spectabilis.}

Loew, Neue Beitr., VIII, 57 ; Mon. N. A. Dol., II, 162.

Aldrich, Trans. Lond. Entom. Soc., 1896, 321 (D. approximatus, n. sp.)

Numerous males and females, one labeled "Windsor estate (Windward), 1500 feet, March 28. Cocoa orchard, on herbage." Comparison with specimens from the United States fully establishes the identity. The only difference between the females of this and simplex is that the latter are, on the average, slightly larger, but doubtless there are individual cases the other way.

\section{Diaphorus simplex.}

Aldrich, Trans. Lond. Entom. Soc., 1896, 333 (Lyroncurus).

Numerous males and females. I have explained the change of generic reference at the beginning of the discussion of this genus.

\section{Diaphorus dubius.}

Aldrich, Trans. Lond. Entom. Soc., 1896, 324.

Five males, seven females.

\section{ASYNDETUS. \\ Loew, Centur., VIII, 58, 1869.}

In this genus the essential character is in the costal rein reaching only to the tip of the third rein, rather than in the fracture, or even the evanescence, of the fourth vein. The latter character's vary somewhat, but in all the species there is at least a marked thinness of the last part of the fourth rein.

Loew considered that the elongated fore pulvilli of the male would keep interruptus in the genus Diaphorus, under which it was described. The shortened costal vein, applying to both sexes conspicuously, seems to me to outrank the size of the male pulvilli. I therefore place the species in Asyndetus.

Table of North American Species of Asyndets.

\footnotetext{
Last part of fourth vein making approximately two right angles........ 2

1. Last part of fourth vein only gently curved in the

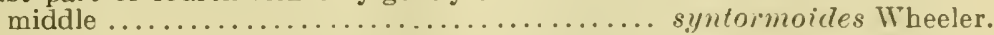

与. $\{$ Fourth rein at the end straight, ending exactly in apex ............ 3

2. $\{$ Fourth vein at the end curved back, ending distinctly behind apex........ 4
} 
Table of North American Species of Asynderus.

Dorsum of thorax with a broad, brown-dusted middle stripe,

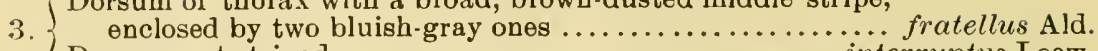

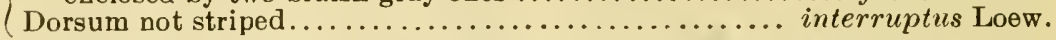

(Second joint of fore tarsi in the male with a large spine, ammophilus Loew.

4. $\{$ Second joint of fore tarsi in the male with two yel-

low processes ........................ appendiculatus Loew.

Note.-The last two are known only from the United States; interruptus is Cuban.

\section{Asyndetus fratellus.}

Aldrich, Trans. Lond. Entom. Soc., 1896, 332.

Two males, two females.

\section{Asyndetus syntomoides.}

Wheeler, Proc. Cal. Acad. Sci., 1899, 32.

One male, two females. The species ranges as far north as Massachusetts, and west to Kansas.

\section{CHRYSOTUS.}

Meigen, Syst. Beschr., IV, 40, 1824.

\section{Table of Species of Chryotus.}

North America, including West Indies.

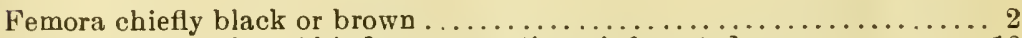

Femora yellow, tips of hind ones sometimes infuscated................. 16

1. $\left\{\begin{array}{l}\text { Hind femora black, middle ones yellow, front ones usually } \\ \text { Hond }\end{array}\right.$ with a dark stripe above (U. S. and W. I.).......... barbatus Loew.

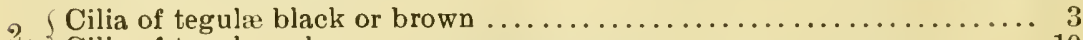

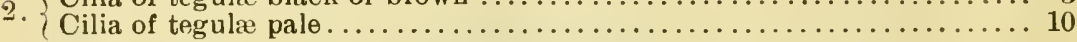

Third antennal joint in the male large, the tip drawn out in a slender point (W. I.) ............................. acutus Ald.

Third antennal joint in the male large, with a blunt tip, upper basal angle rising prominently above the second joint, lower edge straight, eyes of male contiguous ..... obliquus Loew.

Third antennal joint in the male elongate, blunt, symmet-

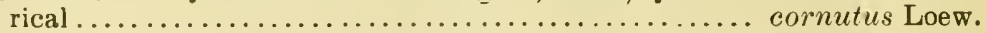

Third joint not conspicuously elongate..................... 4

4. Eyes of male not approximated on the face............ viviclus Loew.

Eyes of male approximated or contiguous................... 5

5. Palpi of male large, projecting, snow white (W. I.)..... albipalpus Ald.

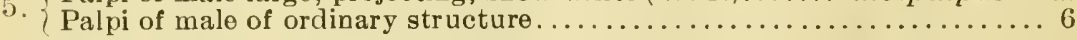

6. Femora metallic greenish black ....................... 7

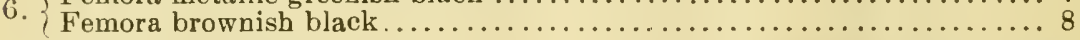

7. Middle tibiæ wholly yellow ..................... obliquus Loow.

Middle tibia largely infuscated ....................... affinis Loew.

8. $\{$ Third antennal joint of male small, plain (W. I.).......... niger Ald.

8. Third joint of male kidney-shaped, arista inserted in an apical notch.... 9

9. $\{$ Tibia black or brown (W. I.) ........................

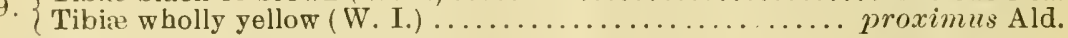

10. Eyes of male approximated.................. choricus Wheeler.

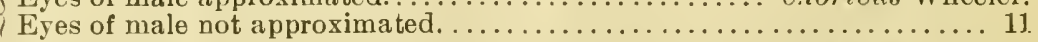

11. $\{$ Palpi white................................ longimanus Loew:

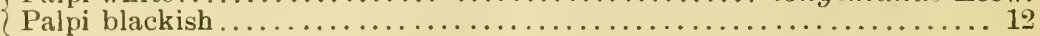




\section{Table of Species of CHryotus.}

12. Wing of male with thickened costa ...................... 13

$\{$ Wing of male without thickened costa........................... 15

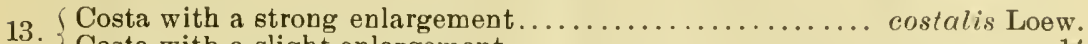

$\{$ Costa with a slight enlargement............................. 14

14. $\{$ Abdomen with pale hairs .................. pratincolr Wheeler.

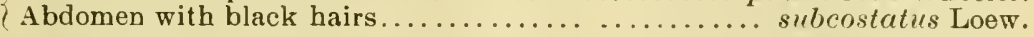

15. $\{$ Femora dark green, shining..................... discolor Loew.

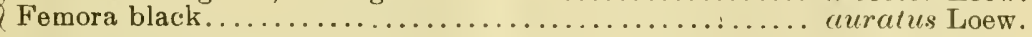

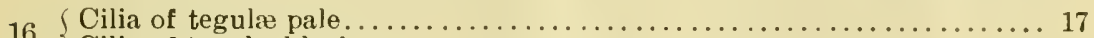

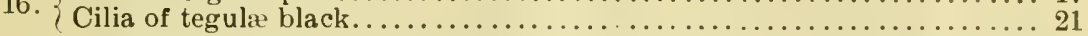

17. \{ Antennæ black, first joint sellow (U. S. and W. I.).... picticornis Loew.

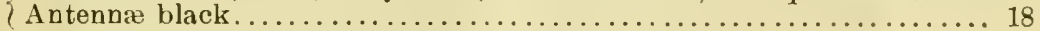

18. $\{$ Eyes of male approximated, not contiguous ................. 19

$\{$ Eyes of male contiguous . .................................. 20

19. $\{$ Abdomen with rather abundant black hair above ....... pallipes Loew. $\{$ Abdomen with very few hairs (W. I.)............... paradoxus, $\mathrm{n}$. sp.

20. Male with dense brown hair down the outer side of the hind

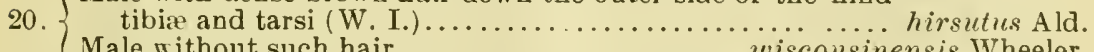
Male without such hair.................. wisconsinensis Wheeler.

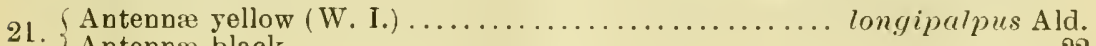

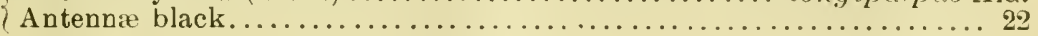

22. $\{$ Eyes of male not approximated (W. I.) .............. inermis Ald.

23. $\{$ Third antennal joint of the male drawn out in a fine point (W.I.), acutus Ald.

23. $\{$ Third antennal joint not drawn out (W. I.) .............. hirsutus Ald.

\section{Chrysotus albipalpus.}

Aldrich, Trans. Lond. Entom. Soc., 1896, 327.

Numerous males and females, one labled "Mt. Gay (Leeward ), 300 feet, Sept. 10. . Flying at sunset."

\section{Chrysotus niger.}

Aldrich, Trans. Lond. Entom. Soc, 1896, 327.

Numerous males and females.

\section{Chrysotus excisus.}

Aldrich, Trans. Lond. Entom. Soc., 1896, 325.

Numerous specimens.

\section{Chrysotus hirsutus.}

Aldrich, Trans. Lond. Entom. Soc., 1896, 328.

Numerous males and females.

Chrysotus longipalpus.

Aldrich, Trans. Lond. Entom. Soc., 1896, 329.

Numerous males and females. 


\section{Chrysotus picticornis.}

Loew, Monogr., II, 184; Wheeler, Psyche, June, 1890, p. 328 ; Aldrich, Trans. Lond. Entom. Soc., 1896, 329.

Numerous males and females. I have seen it also in abundance from Georgia. An easily recognized species.

\section{Chrysotus proximus.}

Aldrich, Trans. Lond. Entom. Soc., 1896, 326.

Numerous specimens. The lighter color, as compared with excisus, applies principally to the fore and middle tibiæ; the thoracic dorsum also is less blue and more bright green.

\section{Chrysotus barbatus.}

Synarthrus barbritus Loew, Neue Beitr., VIII, 48; Mon. N. A. Dipt., II, 138 (see also p. 134) (male only).

Chrysotus validus Loew, Neue Beitr., VIII, 63; Mon. N. A. Dipt., II, 175 (female only).

Tiphandrium americanum Wheeler, Ent. News, VII, 152 (both sexes).

Chrysotus apicalis Aldrich, Trans. Lond. Entom. Soc., 1896, pt. II, 330 (both sexes); Ent. News, XI, 533, synonymy.

Numerous specimens of both sexes.

As will be seen, this species has had peculiar misfortunes at the hands of the describers, in which I have indicated my sliare. If the insect could deceive Loew so completely, certainly the later writers may be pardoned. Professor Wheeler called my attention to the identity of his $X$. americanum with $S$. barbatus. The remainder of the synonymy is my own. The peculiar coloring of the femora has been the main guide in associating these descriptions: Hind ones green, middle yellow, fore yellow, with more or less of a dark stripe above, making a very unusual combination. I see no great impropriety in referring the species to this genus.

\section{Chrysotus paradoxus, n. sp.}

Male: Face narrow, the eyes decidedly approximated, front bright green ; antennæ small, blackish, with minute pale hairs ; palpi minute, dark; dorsum of thorax bright green, the pleur:e blackish; halteres yellow; tegulie yellow, with a few hairs which are decidedly pale in the proper light, but otherwise indistinctly brownish, especially at base. Abdomen bright above, the hairs yellowish or brownish, not distinctly black; venter slightly pale anteriorly; hypopygium mainly concealed, black, with minute yellowish appendages. I notice two rather strong 
hairs, somewhat like those of Diaphorus, but they are not blunt at tip. Legs slender, yellow, with minute yellowish hairs; tarsi rather elongate, last joint but little infuscated, the pulvilli all rather large; middle coxie considerably infuscated. Wings rather slender.

Length, $1.4 \mathrm{~mm}$. One male.

The name is intended to refer to the distinct interblending of the characters of Diaphorus with those of Chrysotus.

\section{MEDETERUS.}

Fischer de Waldheim, Notice, etc., 1819.

Medeterus exiguus, n. sp.

Male: Minute, greenish black, the tibiæ, tarsi and tips of femora yellow, hind metatarsi less than half the length of the following joint and noticeably thicker than it; antennse black, minute; face and the minute palpi black. Hypopygium black, elongate, slender, reaching the hind coxie. I cannot make out the lamellie. Only the apical joint of the tarsi infuscated. Wings hyaline, posterior cross-vein more than its length from the margin, third and fourth veins distinctly convergent. Halteres pure yellow. Bristles of the thorax brownish, almost yellow in some lights.

Female: Hind metatarsi as in the male, but slightly infuscated at tip. Face rather blue above.

Length, $1.4 \mathrm{~mm}$. One male, one female.

\section{CHRYSOTIMUS.}

Loew, Neue Beitr., V, 48 (1824).

Chrysotimus barbatus, n. sp.

Male: Face broad, gray, with a distinct transverse angle or suture, just above which are two distinct hairs nearly as large as those of the orbit; palpi small, dark; front gray; antennæ short, rounded, rather dark yellow, the arista dorsal. Dorsum of thorax, pleurie and abdomen of a dull cinereous cast, with rather pale hairs and bristles. Feet, including coxae and posterior margin of pleure, yellow. Hind metatarsus less than half the length of the following joint, with a fine, dense row of pale hairs forming a brush in the shape of an arc of a circle on the inner side at the tip. This is a cleaning or scraping organ for the wings, body, and other legs, I take it.

Length, 1.6 to $1.7 \mathrm{~mm}$. Two females. 


\section{THRYPTICUS.}

Gerstaecker, Stett. Ent. Zeit., 1866, 43.

Wheeler, Psyche, 1890, 375 (A phantotimus) ; Proc. Cal. Acad. Sci., 1899.

Aldrich, Trans, Lond. Entom. Soc., 1896, 339 (.Tanthotricha) ; Ent. Nows, 1900, 533.

\section{Thrypticus cupuliferus.}

Aldrich, loc. cit. (Nanthotrich(1).

Eight specimens.

Thrypticus minor.

Aldrich, loc. cit., 310 (Tanthotricha).

Nine specimens.

\section{XANTHINA.}

New genus (Tanthos, yellow).

Similar to Tanthochlorus; in the described species without metallic color; bristles of legs brown, of body dark brown, almost black; face very narrow in both sexes, eyes almost contiguous in the male; prescutellar depression very distinct. Antennæe short, first joint minute, third rounded, hairy; arista with moderate pubescence, almost or completely apical ; acrostichal bristles in two rows. Hypopygium concealed, with two hairy filaments nearly as long as the abdomen. Palpi and legs hairy, hind tibixe especially so. Venation as in Chrysotus.

Xanthina plumicauda, n. sp. (Plate IV, fig. 1).

Male: Front and very narrow face, dorsum of abdomen except the base, and a spot below the tegula, black; elsewhere yellow; palpi decidedly large and hairy; hind tibiæe with two rows of pale bristles on opposite sides toward the tip; wings hyaline.

Female: Abdomen dark brown on the middle of the dorsum ; hind tibiæe with ordinary but coarse hairs.

Length, 1.4 to $2.6 \mathrm{~mm}$.; wing about the same. One male, three females.

\section{THINOPHILUS.}

Wahlberg, Oefv. K. Vet. Akad., 184t, 37.

Wheeler, Ent. News, VII, 152-156, 1896.

A single specimen of an undescribed species. As Professor Wheeler is engaged on this genus, I prefer not to describe the present species. 


\section{ACHALCUS.}

Achalcus sordidus.

Loew, Neue Beitr., V, 30, 1857.

Aldrich, Trans. Lond. Entom. Soc., 1896, 339.

Six specimens.

\section{Achalcus caudatus, $\mathrm{n}$. sp.}

Male: Face but little narrowed, blackish; palpi and antennæ small, dark brown, the latter with small, rather pointed third joint, the arista almost completely apical, finely pubescent; hairs of the orbit few, seeming to be paler below. Front and thorax black, overlaid with brown dust, which becomes somewhat bluish gray on the pleure. Abdomen rather dull black. Cilia of tegula yellowish; halteres yellowish, with brown knob. Hypopygium rather disengaged, brown, rounded, in some specimens showing parts of the slender yellow organs inside. Coxie and all the legs and feet sordid yellow; the fore coxie and femorie specially rather dark. Hind metatarsi distinctly shortened. Wings uniform grayish, somerwhat slender, fourth vein ending scarcely past the apex; first vein reaching one-fourth the length of the wing; sixth vein represented only by a slight fold.

Female: Except for the absence of the hypopygium, and a slightly stouter form, the same as the male.

Length, 1 to $1.1 \mathrm{~mm}$. Fifteen specimens, both sexes; one labeled "Windsor" estate (Windward), 500 feet, March 28. Cocoa orchard, on foliage."

\section{PSILOPUS.}

Meigen, Syst. Beschr., VI, $182 t$.

Loew, Monogr. N. A. Dolichopodidæ, 229, 1864. Aldrich, Kans. Univ. Quart., II, 47, 1893.

Psilopus bellulus.

Aldrich, Trans. Lond. Entom. Soc., 1896, 343.

Twelve specimens, both sexes.

Psilopus chrysoprasius.

Walker, List, etc., III, 646.

Loew, Neue Beitr., VIII, 90: Monogr., II, 266.

Aldrich, Trans. Lond. Entom. Soc., 1896, 343.

Numerous specimens, both sexes. 
Psilopus caudatulus.

Loew, Neue Beitr., VIII, 93; Monogr., II, 271.

Aldrich, loc. cit., 343.

Thirteen specimens, both sexes.

Psilopus insularis.

Aldrich, loc. cit., 344.

Two males, two females.

Psilopus jucundus.

Loew, Neue Beitr., VIII, 87; Monogr., II, 258.

GNAMPTOPSILOPUS.

Aldrich, Kans. Univ. Quart., II, 48, 1893.

Gnamptopsilopus flavicornis.

Aldrich, Trans. Lond. Entom. Soc., 1896, 342.

One female.

Gnamptopsilopus flavidus.

Aldrich, loc. cit., 341.

Two males, four females. 


\section{PLATE IV.}

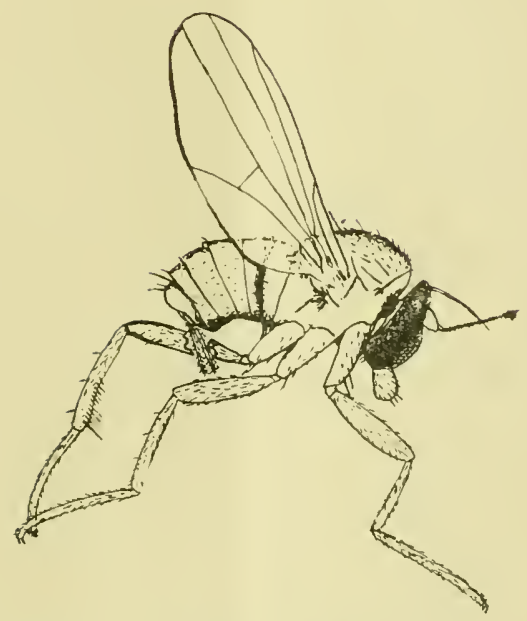

Fig. 1. Tanthina plumicauda.

New genus and species. $\times 20$. The head had become shriveled in drying. 



[Reprinted from Psyche, Vol. XVIII, No. 2, 1911.]

\title{
A REVISION OF THE NORTH AMERICAN SPECIES OF THE DIPTEROUS GENUS HYDROPHORUS.
}

\author{
By J. M. AldRich.
}

The University of Idaho, Moscow, Idaho.

The genus Hydrophorus, established by Fallén in 1823, as limited by Loew in 1857, as generally used since and as herein understood, comprises those flies of the family Dolichopodidæ which have the posterior crossvein located near the hind margin of the wing (distant about its own length, measured on the fifth vein); fourth vein ending in or behind the apex (this excludes Scellus, in which it ends before the apex); front femora thickened (this excludes Liancalus), more or less spinose beneath; dorsum of thorax not with a concave or flattened space before the scutellum (excludes Medeterus); and with the usual single row of postorbital small bristles replaced below with a loose tuft of pale hairs covering all the posterior surface of the head below the neck.

The species are rather small, from 2.5 to about $6 \mathrm{~mm}$. in length. The adults are always found close to the edge of water on wet earth, or else running on the surface of the water. They are carnivorous, seizing smaller flies, etc., and holding them with their raptorial front legs while they suck out the juices. The larræ have not been reported to my knowledge, but it is almost certain that they live in mud at the edge of water.

The adults have a wide range of season, as will be indicated by the dates cited in connection with the descriptions. Considering the fact that several species can easily be found in any locality, the genus has been little collected. This is partly due to the lack of those conspicuous male characters which render some other Dolichopodidæ so interesting, and partly to a general similarity of appearance which has made the taxonomy of the genus comparatively unattractive. Howerer, in the following 
pages it will appear that nothing but a closer study is needed (especially with the new binocular dissecting microscopes) to find characters almost if not quite as interesting as those of Dolichopus.

The North American species were so little known at the time of Loew's monograph of the family that he could describe only three species, to which he afterward added two in the later part of his Centuries. The principal contribution to the genus since that time has been by Wheeler (Proc. California Acad. Sciences, 3rd ser. Zool. Vol. II, pp. 62-69, 1899) in which a table of species is given, five new species described, and numerous'excellent figures published, showing especially the spinulation of the front fenur and tibia, which had been but little appreciated before.

Walker described four species in this genus, of which I think I recognize chrysologus, which had before been identified with his name glaber; the rest are mentioned at the end of this paper. Say's Medeterus lateralis I consider to be a Neurigona, and his punctipennis to be a Pelastoneurus.

Bibliographic references are given herein only where they correct or add to those of my Catalogue, now generally accessible.

A few suggestions about specific characters in the genus will doubtless be of use to those who undertake to determine specimens.

A highly interesting and heretofore unreported character is the presence in three of our species of a row of bristles across the occiput (fig. 4); as the usual pair of postvertical bristles are included in the row, I have referred to them all by that term. The black bristles which form a row behind the upper part of the eye I have termed the postorbitals; they extend much farther down in some spccies than in others. Beneath the neck among the pale hairs called the beard are sometimes several black bristles; they are too hard to see to be of much importance in classification, but I have mentioned their occurrence when I could see them. The width of the cheek at the lower edge of the eye is an important character, but it is difficult to measure it by anything very tangible; the student will need to gain his ideas by comparing several species. The metallic color of the face, and its alternative, the complete opacity of the face, might not seem to sound very definite, but I think they work out very well. I find hardly a species difficult to place by this character. The antennæ 
generally are of little diagnostic value. They are always wholly black, except in some cases where there may be a whitish tip to the arista, which I do not find worth mentioning; in a few species the first joint of the antenna is elongated, and in cerutias, especially the male, there is a remarkable elongation of the whole organ (fig. 5). The width of the face and the color of the palpi are occasionally unusual and useful.

The thorax presents many opportunities for distinguishing species, especially in its chætotaxy. The scutellar bristles are uniformly four except in gratiosus (2), intentus (6), plumbeus (10), and cerutias (2). The numbers above four may be expected to be a little variable. The notopleurals are generally two, but are only one in gratiosus, intentus, plumbeus, cerutias and agalma. Not to prolong the list too much, the dorsocentrals vary ir their size, some species having them large and others small; one species, canescens, has them white, a striking feature. The propleural (just above the front coxa on the side) shows some interesting changes; in plumbeus there are several, in all the rest one except cerutias, canescens and agalma, which have none; in phoca, the single propleural is yellow instead of black. The pleura often has fine, pale hairs in noticeable clusters in very definite spots, which I have mentioned in many cases. The halteres may be wholly yellow, or the knob may be more or less infuscated, and these two alternatives divide the genus more naturally than any other I can find, hence I have made primary use of them in my table. The wings offer few valuable characters. One of the first class is found in cerutias, but was overlooked by Loew-the extreme shortness of the second vein (fig 1). No other North American species has this peculiarity. The two spots on the wing in a few species are very constant, but other species have them in a very faint degrce, also constant, which makes the character unavailable in a table except in one group. The paleness of the veins at the base is rather variable and I have found it of little use except in a few species. The abdomen presents very few salient characters. The hypopygium of the male varies so much in drying that it is almost impossible to make any use of it, while in other Dolichopod genera it is often of the greatest use and value. The legs except the front ones offer few characters. I have paid considerable attention to 
the small black bristles of the front coxæ; while they are somewhat inconstant, they yield some good distinguishing marks. The front femora have on the under side some short stiff spines, against which the tibia closes with its row of spinules, thus holding the prey while it is devoured. This arrangement is repeated in many slightly varying forms in the different species, but in three, canescens, amplectens and breviseta, a secondary modification has taken place in the male, furnishing special grasping organs which must be for the purpose of holding the female, since they are confined to the male sex; in amplectens it is a question if the second function has not superseded the first. The middle and hind legs offer a few slight and one (breviseta) rather striking ornamental or other male characters.

In the measurements I have included the length of the wing, as the abdomen shrivels to such a variable extent that the length of the body becomes untrustworthy except in a general way.

\section{Table of Species.}

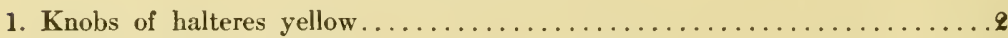

Knobs of halteres infuscated, at least on outer side...............

2. Postvertical bristles in a row of six or more (fig. 4) $\ldots \ldots \ldots \ldots \ldots \ldots \ldots, 3$

Postverticals only two as usual......................... 5

3. Scutellar bristles one pair................... gratiosus sp. nov.

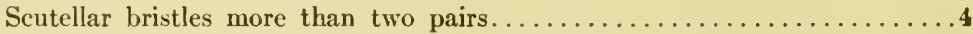

4. Propleural bristles several................... plumbeus sp. nov.

Propleural bristles (black) none or only one........... intentus sp. nov.

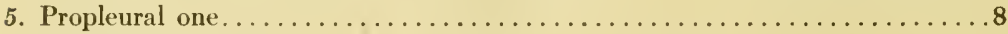

Propleural none..................................... 6

6. Second longitudinal very short, ending opposite hind crossvein

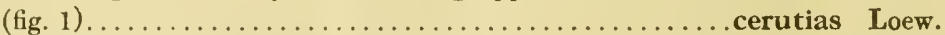

Second vein normal, much longer (figs. 2,3$) \ldots \ldots \ldots \ldots \ldots \ldots \ldots \ldots$.

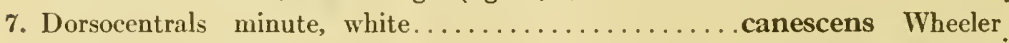

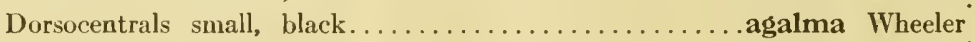

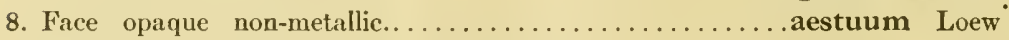

Metallic color visible on upper part of face.................

9. Tip of front tibia in both sexes with an acute angle produced toward the femur (one to three bristles on upper outer corner of front coxa, and the face generally very bright blue-green as far down as the suture $) \ldots \ldots \ldots \ldots \ldots \ldots \ldots \ldots$ philombrius

Tip of fore tibia not or but slightly angulated toward the femur (face not shining so far down, generally no bristles on basal part of front coxa).

10. Front tibia of male notched on inner side at two-thirds its length 
(fig. 10

breviseta Thomson.

Front tibia not notched.............................

11. Size 3 mın.; pleura with rather thick white pruinosity.... sodalis Whecler. Size $4.5 \mathrm{~mm}$.; pleura with thin yellowish pruinosity.... magdalenæ Wheeler.

12. Wing with a brown spot on the middle of the last section

of the fourth vein, and another on the hind crossvein (fig. 2) ......... 13

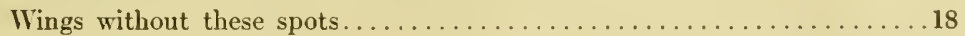

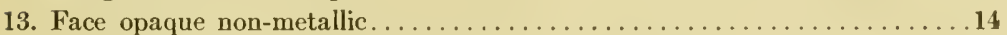

Face showing some metallic color . . . . . . . . . . . . . . . 17

14. Face brownish-yellow; a gray spot on each side below... signiferus Coq. Face not so marked . . . . . . . . . . . . . . . . . . . . . 15

15. Front coxæ with black bristles on the front side besides those at

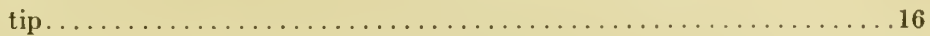

Front coxæ with no black bristles except at tip...... $\sigma^{7}$ algens Wheeler.

16. Wings with the spots distinct enough to see with the naked eye.chrysologus IVlk The spots only faintly visible with a lens . ............ pirata Loew.

17. With a black propleural bristle ............. o algens Wheeler.

With a pale bristle or stout hair................ phoca sp. nov.

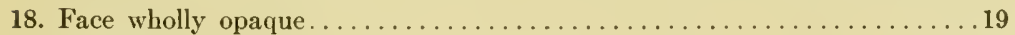

Face showing some metallic color . . . . . . . . . . . . . . . . . . 20

19. Front coxa with a row of black spines in front, longest above, running out apically.......................... parvus Loew.

Front coxa with a row of spines, longest toward the tip, running

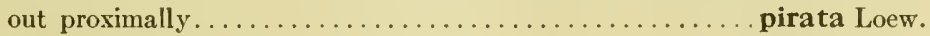

Front coxa with no spines except at tip ........... extrarius sp. nov.

20. Front coxæ with long and striking spines on the basal part in front............................. innotatus Loew.

Front coxæ with no spines on basal part in front................

21. Cheeks projecting downward in a small lobe below the eye

altivagus sp. nov.

Cheeks not forming a lobe below the eye, very narrow .............2

22. Male with a protuberance preceded by a tuft of small spines on

the under side of front femur near tip (fig. 13)..... amplectens sp. nov.

Male without such structure ...........................23

23. Upper part of the face bright blue-green ........... pensus sp. nov. Upper part of face dull, only a little greenish........ extrarius sp. nov.

\section{DESCRIPTION OF SPECIES.}

(Made with 'Zeiss binocular dissecting microscope, 30 diameters.)

Hydrophorus gratiosus sp. nov.

Male. Occiput bluish-green above, with moderate whitish pruinosity; postvertical bristles rather close together, with about four bristles each side, forming a row that joins the postorbitals both ways; the latter extending below the middle of the eye, beard whitish, a few stiff black spines showing just below the neck; front with dense brown pruinosity, not shining; face dirty whitish pruinose, not shining, of medium width; palpi of moderate size, black in ground color, opaque 
like face, with mostly whitish hairs; antennæ with rather long first joint, the third wide, all black. Dorsum of thorax moderately shining, with two brown lines in front, in the middle brown, back of the middle a little coppery on both sides; humeral bristles one or two, scutellar one pair; a bunch of long, whitish hairs behind humerus and above the notopleural suture, pleuræ densely whitish pruinose, not shining, with conspicuous whitish hairs on propleura and hypopleura, the propleural bristle however black; halteres yellow with brownish base of stalk. Coxæe all with yellowish-white hairs and no black ones even at tip of front coxæ; femora rather opaque, with slight greenish metallic color, tibiæ and tarsi gradually a little darker; fore femur with numerous short, stiff spines below, arranged very indistinctly in two uneven rows; fore tibia on inner side with a row of short spines, the last two or three at tip becoming erect and slightly longer; the tibia itself is provided with a slight process at tip, turning toward the femur, on which the longest spine stands; fore tarsus fully double the tibia, pulvilli brownish. Wings smoky, costa wholly blackish, an indistinct brown cloud on the hind crossvein and another beyond it on the fourth vein. Abdomen rather shining green, with black hairs above and whitish ones on the sides, the latter rather conspicuous; hypopygium embedded, not very conspicuous. Length, $4 \mathrm{~mm}$; of wing 4.3.

Female. Length 5 to $6.1 \mathrm{~mm}$.; of wing 5.6 to $6 \mathrm{~mm}$.; otherwise like the male.

Seventeen specimens, both sexes: Moscow, Idaho (type); Pullman, Seattle and Friday Harbor, Wash., dated July 19 and Aug. 2 and 16; Palo Alto and Redwood City, Cal., dated March 1 and April 12, 19 and 25. Three of the Washington specimens are from Professor Melander, while one from Palo Alto is from the collection of Stanford University.

Another male from Moscow differs in nothing but its minute size, $3.1 \mathrm{~mm}$.

Hydrophorus plumbeus sp. nov.

Female. Wholly coxered with dense plumbeous pruinosity, nowhere showing . any metallic color. Occiput with a transverse row of black bristles including the postverticals, which are continuous with the infra-orbitals extending entirely to the mouth; the upper orbitals do not quite connect with this series, so there are half a dozen small black bristles on the upper orbit which are a little isolated from the ones on the orbit below; no black spines under the neck; front plumbeous, yet in oblique view rather blackish, not shining; face very wide, uniformly plumbeous, the palpi concolorous, in the described specimen opened out so that the base of the proboscis shows between-probably not the usual position; antennæ of moderate length, rather slender, the third joint truncated, arista short, its penultimate joint over half as long as the ultimate, which is hardly tapering at all except at the extreme tip, but ends in a very fine point. Thorax everywhere plumbeous, but with two fine dark lines running back from the front edge in the middle; humeri each with three or four bristles of various sizes; on the mesial side of the humerus a group of bristles, and another behind the humerus and above the notopleural 
suture, where a cluster of whitish hairs occurs in some species (gratiosus); propleura with long white hairs and a bunch of black bristles above the coxa; metapleura also with white hairs; scutellum with a row of erect convergent bristles on the margin on each side, five or six in each; some supernumerary bristles also before the scutellum; halteres yellow. Front coxæ with white hair, long above and shorter below, and a row of snall black bristles just above the trochanter; middle and hind coxæ with only fine white hair; front femur with irregularly placed spines of all sizes below, indistinctly arranged in a double inner and a single outer row; front tibia stout, gently curved, ending in a slight process with one conspicuous spine, the rest of the inner spines almost imperceptible; the other legs and all the fect somewhat bristly; pulvilli brownish; the legs in every part showing the characteristic plumbeous pruinosity of the species. Wings rather opaque whitish, with a faint brown cloud occupying all the apical two-fifths except a whitish spot in the first posterior cell, and another spot of deeper brown with its center in the basal part of the discal cell and diffusing into the surrounding cells; veins black.

Length, $5.6 \mathrm{~mm}$;; of wing, 5.7.

A single female, Grand Coulee, Wash., Soap Lake, June 29, 1902 , from the collection of the Washington State College through Professor Melander.

This species has so many well-marked characters that it is unnecessary to enumerate them. It was collected at a small lake of strongly alkaline water.

\section{Hydrophorus intentus sp. nov. (fig. 4.)}

Male. Everywhere covered with a dense pruinosity, yellowish except on the dorsum of the thorax, and front where it is brown; metallic ground color not visible exccpt very slightly on the abdomen. Occiput with a row of spines extending each way from the postverticals and joining the orbitals rather far down the side; the orbitals extend down nearly to the lower border of the eye; behind them the usual beard is yellowish, and there are black spines under the neck; front sealbrown, face uniformly yellowish pollinose throughout, palpi concolorous in favorable light; antennæe wholly black, first joint moderately long and slender, third mide. Dorsum of thorax rather uniformly brown, humeri lighter; humeral bristles two or three, scutellar about three pairs which are convergent and rather erect, the outer sometimes considerably smaller; propleura with long yellowish hairs and one black bristle; metapleura with fine soft yellow hairs and a few still smaller behind the humerus, above the notopleural suture; halteres yellow. Hairs of the coxæ all pale yellow, long on front ones, which have some black spines on the hind side, next the body, hard to see. Fore femur with two rows of spines underneath, the outer of about seven quite uniform, the inner with four or five larger and an irregular intermixture of smaller ones; front tibia almost straight, with a row of small spines on inner side, the last one larger and erect, standing on a slight elevation; pulvilli brownish. Wings somewhat uniformly brownish, the veins almost black, not lighter at base, an almost imperceptible cloud on the hind crossvein and another 
beyond it on the fourth vein. Abdomen very faintly greenish, cylindrical in middle, the hypopygium small and concealed, not cutting into the fourth sternite at all.

Length, $4.5 \mathrm{~mm}$.; of wing 4.6 .

Female. Differs only in having the abdomen wider in the middle, and showing a rather bright blue-green metallic color on the whole dorsal surface of the abdomen; also in the larger size, $4.9 \mathrm{~mm}$.; of wing 5.1 .

Forty-one specimens: Horse Neck Beach (type), Woods Hole, New Bedford, Chelsea, Cohasset, Chatham, all in Massachusetts; Atlantic City, N. J. The Mass. specimens are dated from May 14 to Sept. 8, and were collected by Messrs. Johnson, Hough and Melander. The New Jersey specimens are dated May 6, and were collected by C. W. Johnson, who informs me that this is the commonest salt marsh species. Professor Melander also reports it extraordinarily abundant in salt marshes at Woods Hole.

I received this from Mr. Johnson under the name of viridiflos Walker, but I do not see how it can be Walker's species. Walker's description is mostly made up of items that would apply to almost any kind of Hydrophorus, or in fact to many other flies; the only character which seems of any diagnostic value is "wingribs and poisers tawny; veins black, tawny at the base." I do not understand the distinction between wingribs and veins, but it seems clear that he was describing a species, of which there are several, in which the basal part of the veins is yellow. This character does not apply at all to the species here described. It suggests $æ$ ituum to me much more than intentus, as Walker mentions a length of $3 \mathrm{~mm}$.

Hydrophorus cerutias Loew (figs. 1, 5).

Male. Occiput bright green, with only one pair of postverticals; postorbitals about eight on a side, extending down only about one third of the way to the mouth; beard yellow or whitish, dense; cheeks not visible at all below the eyes; no black bristles under the neck; front yellowish or brownish pruinose; face long, narrow above, wholly white pollinose, palpi concolorous and with rather long pale hairs; antennæ located rather high and pointing almost vertically upward; all the joints elongated, but the third drawn out into a point along the upper edge (see figure); arista short, the basal joint flattened so as to look like the tip of the third antennal joint. Thorax quite bright green or bronze above, especially bright behind; scutellum with only one small decussate pair of bristles, acrostichals and dorsocentrals extremely small, humerals one medium and sometimes one small, notopleural one; a tuft of pale hairs behind the humerus, above the suture; pro- 
pleura with long yellowish or whitish hairs and no black bristle; mesopleura with long hairs of the same color on the lower anterior part; metapleura just in front of halter with a conspicuous tuft, which blends with a similar but shorter one on the posterior upper part of the sternopleura; halteres yellow with brown root; all the coxæ with dense yellow or whitish hair on front side, the front ones with also a lateral tuft near base and no black bristles; front femur not much thickened, on under side with two irregular rows of stiff bristles, and in the rather wide space between the rows numerous irregularly placed short spinules; fore tibia with a row of short spines of increasing length and erectness towards the tip, where the last and largest spine is on a curved point of the tibia; in addition to this row there is on the outer side from it (laterad) another row of larger, more scattered, slanting spines, some ten in number; middle and hind femora slender, rather long, somewhat bowed. Wings slightly infuscated, unspotted, of medium shape, strikingly distinguished by the shortness of the second longitudinal vein, which ends opposite or a little before the hind crossvein (see figure); veins broadly yellow at base. Abdomen bright green, pruinose on sides below, with thin white hairs all over, longest and conspicuous on the sides of the basal joints; hypopygium bulky but short, bent under but not extending much forward. Length, $3.6 \mathrm{~mm}$; of wing, $3.7 \mathrm{~mm}$.

Female. Considerably larger and brighter green than the male; third antennal joint not drawn out into a point as in the male, yet all three of the antennal joints may be called elongated; the face and the pale hairs of the body surface are yellow, the the latter quite variable in depth of hue. Length, $5.1 \mathrm{~mm}$., of wing the same.

Three, males and seven females: Douglas Co., Kans. (Univ. of Kans. Coll.); Brookings, S. D.; Pierre, S. D.; Boulder, Col.

This species has such a wealth of specific characters that a lengthy description seems almost unnecessary. The male has a very remarkable appearance as it goes skating across the surface of a pond, the long antennæ pointing upward like a donkey's ears. I well remember seeing it near Lawrence, Kansas, in June, 1893, though the males in my collection are not of my own capture, all being from the University of Kansas collection. The females collected by me in South Dakota and Colorado were not recognized at the time. It was Professor Melander's quick eye that first noticed the peculiarity of the second vein, not mentioned by Loew.

\section{Hydrophorus canescens IVheeler (fig. 9).}

Ma'e. Occiput coppery red, with only one pair of postverticals; postorbitals about twelve on a side, ending opposite the neck; beard white, abundant, mixed under the neck with some black bristles, which seem rather large and numerous; cheek very narrow; front whitish pruinose, only in certain lights with a little coppery reflection; face wholly white pollinose, palpi concolorous with white hairs, antennæ short, of ordinary form. Thorax coppery red or even crimson on most of the dorsum, greenish about the edges, the acrostichals and all the dorsocentrals 
exeept the posterior pair white; a single pair of scutellars; two humerals, two notopleurals (both large), one posthumeral; propleura with two clusters of long pale hairs, above and below, among the latter some have a rather dark appearance in eertain lights, but there is no black bristle; on the upper part of the sternopleura is a cluster of long, loose, woolly, white hairs, very conspicuons; metapleura bare; squama pale yellow with white hairs; halteres yellow, a little brownish at the root. Front coxæ white pollinose and covered in front with long, erect and dense white hairs, no black spines or bristles at tip; front femora thiek, not tapering for more than half their length, then with a deep, oblique excavation below cutting ont more than half the thickness of the member, beyond which the under side is widened again in a thin longitudinal plate to the tip; the sloping proximal surfacc of the excavation bears a diagonal series of short black spines; the femur has rather conspicuous white hair on its outer side and on the inner side before the excavation are several much longer white hairs; front tibia strongly bowed out where they oppose the exeision of the femur and bare on the flat opposing surface except for a row of minute black spines on the edge which continue, though very small, to the tip; on the underside of the femur near the base are a few short spines in a row; middle coxa with long, erect white hairs on outer part of the front side; middle and hind femora long, slender and somewhat bowed; hind trochanter below with a bunch of blaek spines which unite to form a tapering, sharp, thornlike process, very striking: middle tibia and tarsus shortened, not much longer than the femur, last tarsal joint flattened and enlarged, black. Wings rather wide with veins yellow at base to a variable extent, unspotted, evenly and moderately infuscated in color; first posterior cell narrowed at end, not much more than half as wide as the length of the posterior crossvein; alula with a row of long, white laairs. Abdomen coppery above, more or less obscured with white pruinosity; all the hairs of the abdomen are whitish and of unusual length, those on the sides near base quite woolly and very striking; fourth sternite projecting V-shaped; hypopygium moderately prominent but not uniformly so. Length, $4.8 \mathrm{~mm}$; of wing, $5 . \mathrm{mm}$.

Female. Color of face from pale yellowish to brownish; front femur gently tapering, not notched, below with an irregular double row of small spines; front tibia with a row of minute spines on inner side which does not extend to the tip. Length, $5.3 \mathrm{~mm}$; of wing, $5.2 \mathrm{~mm}$.

Seven males and two females: Lawrence, Kans., June, 1893; Brookings, S. D.; and Green River, Wyo., Sept. 1, 1896. I remember collecting the specimens at the edge of the river at Lawrence, and I at once noticed the peculiar front legs of the male. The Green River specimens were taken on an occasion when I had to wait between trains all day at the town, but I do not remember the species. My description does not sufficiently bring out the characteristic pale yellowish soft dull coloring of the whole $\mathrm{fly}$, which suggested the specific name. Only the coppery dorsum and greenish abdomen are moderately bright. The type locality was forty miles north of Lusk, Wyoming. 


\section{Hydrophorus agalma Wheeler (fig. 12).}

Male. Occiput rather coppery green, with one pair of postverticals; postorbitals about a dozen, descending about a third of the eye-height; beard white, abundant and long, no black bristles under the neck; the eye meets the mouth, so there is no cheek; front opaque whitish in side view, but coppery with light from behind; face wholly white pollinose, palpi of same color, with white hairs; antennæ small, of ordinary form. Thorax with strong coppery reflection on the disk, mostly outside the dorsocentrals, a dark line in front on each side of the acrostichals. The acrostichals and dorsocentrals are very small in front, but black; hindmost ones very large; scutellar two pairs, large; humeral two, small; notopleural one; pleuræ densely whitish pollinose; propleura with two tufts of long white hairs, one above the other, but no black bristle; sternopleura on the upper part with some scattering very long white hairs; pleurse otherwise bare; metapleura just in front of the halter with a peculiar protuberance, almost hemispherical; halter yellow with brownish root. Front coxæ whitish pollinose, with abundant long white hairs in front and no black spines; front femur tapering, below with a row of short, blunt spines extending nearly to the middle, about eight in number; front tibia rather straight, with a row of slanting black spines on the front (outer) side, and on the inner a very close row of minute black spinules, rather erect, ending at the tip with two larger small spines; the tibia has on the outer side two or three regular rows of pale hairs; middle femur with a row of long white hairs or bristles on the lower side; the middle tibia and tarsus are rather short, and the last joint of the latter is flattened and black; middle and hind legs provided with an unusual amount of fine white hair. Wings unspotted, rather broad, slightly infuscated, the veins broadly yellow at base, alula with a conspicuous fringe of white hairs, first posterior cell considerably narrowed at tip. Abdomen with a dull coppery reflection, the hairs all white and very long on the sides near the base. Hypopygium bulky, but mostly concealed. Length, $5.2 \mathrm{~mm}$.; of wing, $4.9 \mathrm{~mm}$.

Female. The pollen of the body is a little yellowish, and the face is decidedly yellow; the front femur below has an irregular double row of spines, 25 or 30 in all; all the spines of the front tibia are larger; no white bristles under the middle femur; middle tarsus normal; sides of abdomen with shorter hairs. Length, $5 \mathrm{~mm}$;; of wing, $5.3 \mathrm{~mm}$.

Three males and two females, collected by me at Battle Creek, Mich., in the summer of 1897; Professor Wheeler's types were out of this lot.

The species has many interesting points of resemblance with canescens, but also has easily discerned differences.

\section{Hydrophorus eldoradensis Wheeler.}

Hydrophorus aestuum Loew.

Male. The whole insect covered with whitish pruinosity, less dense on the dorsum, which shows a little metallic color. Occiput with only two postverticals, and only six to nine postorbitals on a side, extending only about a third of the way to the mouth; beard white, no black bristles under the neck; cheeks hanging down as a vertical flap below the eyes, which is short antero-posteriorly; face very wide, 
wholly white pollinose, antennæ of usual form, small, first joint not elongated. Thorax with two small cupreous stripes in front, enclosing the acrostichals and extending to the middle; outside the dorsocentrals is a wider cupreous stripe on each sidc abbreviated at both ends. These stripes are often but little visible. Scutellars two pairs, humerals two, notopleural one and sometimes another much smaller; squama pale yellow with white hairs; halteres pure yellow with a dark root; propleura with white hairs and one black bristle; a few microscopic white hairs on sternopleura; front coxæ with white hairs in front and few minute black spines at tip; fore femur on the under side with one row of spines of irregular size, larger along the middle. These are on the inner side of the folded tibia, but at the tip is a single spine that comes on the outer side. There is a little variation in these femoral bristles, and in one of Wheeler's cotypes of eldoradensis, a male, from Magdalena Mts., N. M., I find by removing the tibia that the femoral bristles consist of a series near the base of about five minute ones bent laterad and three larger ones near the middle, standing straight down; these all form a row as far as their insertion is concerned. Wheeler's description of two rows must refer to the female. Tibia with a row of setules on the inner side, progressively longer and more erect' toward the tip, the last one still longer and standing on a sharp inwardly curved point of the tibia. Middle and hind femora simple, slender but not greatly elongated, both a little bowed. Wings hyaline, unspotted, of medium size, the veins broadly yellow at base; this yellow color varies greatly in different specimens, but generally the costa is yellow to a point about halfway between the tips of the first and second veins. Third and fourth veins quite strongly convergent at tips.

Abdomen more or less greenish, rather broad and short, covered with white hairs; the male appendages are so small and retracted that it is often difficult to determine the sex of the specimen. Length, $3.2 \mathrm{~mm}$.; of wing, $4.5 \mathrm{~mm}$.

Female. Postorbitals about a dozen on a side; bristles of the lower side of front femur in two rows, which are a little irregular near the middle.; Length, $4.5 \mathrm{~mm}$.; of wing, $5.3 \mathrm{~mm}$.

Thirty specimens, both sexes: Magdalena Mts., N. M., Aug1894, W. A. Snow; Las Cruces, N. M., Aug. 23; 40 miles north of Lusk, Wyo., July, 1895; Palo Alto, Cal., Aug. 6, 1894 (all the seren preceding specimens are cotypes of Professor Wheeler's eldoradensis, from Professor Melander's collection); Texas, October 18, 1899; Jacksonville, Tex., Oct. 20, 1895; Tifton, Ga., Sept. 24, 1896; Biscayne Bay, Fla. (Mrs. Slosson); De Funiak Springs, Fla., Mar. 1, 1900; Brookings, S. D., one pair copulating on surface of water, Apr. 10, 1900; Moscow, Ida.; Pacific Grove, Cal., on seepage of sand dunes near sea beach, May 6, 1906; Palo Alto, Cal., Oct. 7, 1905; Redwood City, Cal., Apr. 25, 1906; California (Coquillett).

The type locality of aestuum was Newport, R. I., which with Johnson's recently published New Jersey records, nicely rounds 
out the localities so that they cover practically the entire United States. This is undoubtedly the most wide-spread species that we have; it is also considerably variable in several of its characters notably the amount of white pruinosity it bears. A specimen sometimes looks quite metallic on one side, showing that a slight amount of rubbing easily takes off the "dull finish" provided by nature. The coppery stripes on the thoracic dorsum are sometimes only green, sometimes almost obsolete. In general, it may be described as a small species with considerable whitish pruinosity, opaque face, white hairs all over except the distal portion of the legs, and with hyaline wings, unspotted, the veins yellow at base. Loew failed to mention the paleness of the wingveins, which misled Professor Wheeler. Mr. Brues compared some of my material with Loew's types of astuum at the museum of Comparative Zoölogy, and could find no material differences.

Osten Sacken, in his Western Diptera, p. 320, probably had this species, - the second undetermined species mentioned.

\section{Hydrophorus philombrius Wheeler (fig. 14).}

Male. Occiput moderately shining green, the postvertical bristles only a single pair, vertex considerably excavated on each side of the ocelli, which are on a tubercle; front shining green, concave, wide above; face concave above the middle, smooth and brilliantly shining, the metallic color usually continuing down over the suture, which is elevated on a protuberance; there is considerable variation in the brilliance of the color, even on the upper face, but it is always perceptible; below the protuberance sloping backward to the palpi, which are darker with brownish hairs. The cheek a thin sharp plate, yellowish sericeous, standing straight down on each side of the mouth; the face widens rapidly from a point just below the antennæ; the black postorbital bristles extend down behind the eye only about to the middle; beard whitish and dense, making it impossible to tell certainly whether there are any black bristles under the neck, though 1 think there are; antennæ short, the first and second joints of about equal length. Thorax above striped with green and coppery, the former color occurring along the rows of bristles; only a single row of acrostichals, beginning rather far back; dorsocentrals small except the hindmost one; scutellars four, strong; two humerals; the hind notopleural small; pleura rather dull with gray pruinosity, almost destitute of fine hairs; propleura however with whitish hairs, longest just below the single black bristle; front coxa with a somewhat sericeous whitish pruinosity, and fine white hairs, also at the upper outer corner two or three small black bristles and five or six on the outer side of the front near the tip; femur thick at base, rather bare, below with two rows of bristles at base, the outer of only about four rapidly increasing ones and the inner of five or six of rather uniform size, and beyond the latter a few extremely short little stubs showing above the surface; front tibiæ strongly curved inward at tip, 
and bearing on the inner side a row of little spines, quite erect all the way, the terminal one not large; the other femora and tibiae quite shining; halteres yellow to dark yellow, the knob not with a darker spot, the stem dark at base. Wings almost hyaline, without spots, the veins yellow at base as far as the middle of the basal cells and the first vein farther, the costa however only pale halfway to the humeral. Abdomen greenish, short, with whitish hairs on the sides and below, fourth sternite divided, behind it a pair of blackish protruding flaps.

Length, $3.9 \mathrm{~mm}$.; of wing, 4.2 .

Female. Face generally not bright below, yet distinctly green in the concave upper portion; front coxæ with the black spines quite small; dorsum of thorax more opaque, hardly shining.

Length, 4.8 of m. m; wing, 5.5.

Thirty-two specimens: Battle Creek, Mich.; McHenry, Ill. Lawrence, Kans.; Brookings and Pierre, S. D.; Austin, Tex.; Moscow and Craig's Mt. in Idaho; Palo Alto and Pacific Grove, Cal.; Longmire's Springs and Coulee City, Wash. The last and the material from 'Texas and Illinois are from Professor Melander. Dates: Austin, Texas, Oct. 29 and Dec. 25; Palo Alto, Apr. 12; Pacific Grove, May 6; Brookings, S. D., Apr. 25; Longmire’s, Aug. 2; Coulee City, June 25 and July 13. The species evidently has a long season as well as a wide distribution. The dated specimens from Brookings have some personal interest, as I collected them in the spring of 1890, just after I had decided, under the advice of Professor A. J. Cook, to take up the Diptera as a specialty.

Hydrophorus breviseta Thomson (figs. 10, 11).

Male. Occiput green, with a bluish pruinosity, postvertical bristles only two; orbitals extending about two thirds of the way down behind the eye, beard yellow, numerous stiff spines below the neck; front opaque brownish; face green above, below with some brown pollen: the eyes reach as far down as the lower edge of the face, and the cheek is in the form of a very narrow vertical plate; palpi dark brown with hairs of the same color; antennæ small and very short. Dorsum of thorax rather brown, not shining, with a row of small lighter spots on each side, where they intervene between the dorsocentrals; four large scutellars; pleuræ rather green in the middle, whitish pruinose below; propleura with conspicuous yellowish hairs and one black bristle; mesosternum with thin, pale hairs; halteres rather deep yellow. Front coxæ with scattered pale hairs and at tip a few small black spines; front femur thick at base, on its lower side at extreme base ąbout five little black spines with some whitish hairs, then about the middle a row begins of very long bristles which decrease rapidly; front tibia with a swelling on the inner side, largest just beyond the middle, followed by a deep excavation, beyond which to 
the tip the outline again rises; the outer side of the tibia is also crooked and convex over the excavation, and along almost its whole length has distinct, long hairs; the inner side is provided with a row of short, erect spines, beginning before the middle, interrupted at the excavation, and continuing again in only three or four spines to a point halfway between the latter and the tip, so that there are no spines near the tip at all, but only delicate pale hairs on the inner side, tarsi simple, with brownish rather large pulvilli. Middle femora slender, a little bowed; middle tibir with a few extra bristles on the inner side near the tip; tarsus a little shorter than the tibia, its first joint bristly on the inner and hind side, the last two joints black, flattened, and with a dense tuft of stout black hairs on the hind side of each; pulvilli and empodium rather large, brownish. Hind legs of ordinary form. Wings slender, but faintly infuscated, a rather distinct spot on the hind crossvein but none beyond, veins black, humeral and the large stem behind it somewhat paler; abdomen moderately shining above, rather long, strongly concave below; underneath the fourth segment are two flaps with yellow hair; terminal organs large, folded under.

Length, $3.9 \mathrm{~mm}$; ; of wing 4.8 .

Female. Instead of the long bristles on under side of front femur, there are only a row of short, stiff ones; the front tibia is provided with a simple row of small slanting spines on the inner side, not interrupted and extending to the tip.

Length, $4.3 \mathrm{~mm}$; of wing, 4.9 .

\section{Four males and four females: three males and three females} were collected at Friday Harbor, Wash., July 17, 1905; two males and two females, same locality, collected by Professor Melander on July 7, 1909; one female, Kanaka Bay, San Juan Island, Wash., (four miles from Friday Harbor) May 31, 1906; and one male sent me many years ago by Mr. Coquillett, Alameda, Cal., which is presumably just about the type locality.

\section{Hydrophorus sodalis Wheeler.}

Male. Occiput green, moderately shining, with only the usual two postverticals; front rather obscure green; face wide, shining green close to the antennæ, but with a white pollen covering the lower two-thirds; palpi brown; postorbitals scarcely coming down to the level of the middle of the eye-just ten on a side in the described specimen,- - beard dense and white, no black spines under the neck; cheek forming a narrow vertical plate, densely white pollinose; antennæ small, first joint short. Thorax and scutellum greenish bronze, rather shining; acrostichals in a row of five, dorsocentrals sixin each row, the fifth longest, but all rather long, scutellar four, strong; pleuræ with dense white dust, especially below; propleura with long white hairs and one black bristle, no other hairs on pleura except a few microscopic white ones on the upper hind part of sternopleura; halteres dark yellow: wings almost pure hyaline, unspotted, third and fourth veins rather widely separated at tip. Color of reins black, scarcely lighter at base. Front coxæ with short white hairs, usually a few minute black setules at apex, and occasionally a 
small black hair near base; front femora thick at base, below with white hairs on outer side and a row of about four stiff spines near base, on the inner side below with numerous black spines in one row, "five to seven spines in the broader basal portion of the femur are considerably longer than the other spines, which are inserted in two or three irregular rows." Inner side of the front tibia with a regular row of stiff spines, running up on a slight process of the tibia at its distal end. Middle and hind legs simple, tarsi blackish with yellowish pulvilli. Abdomen short and compressed, bronze-green, the hypopygium retracted. Length, $2.9 \mathrm{~mm}$.; of wing 4 .

Female. Beard and hair of front coxæ more yellowish; the postorbitals come down two-thirds the height of the eye-thirteen in number in the specimen. Wings a little more infuscated. Length, $2.7 \mathrm{~mm}$.; of wing, 4.7 .

The description is drawn from eight cotypes in Professor Melander's collection, Hunter's Creek, Wyo., Sept. 11, 1895, Lusk, Wyo., Aug. 26, 1895, and Black Rock Creek, Wyo., Sept. 13, 1895. I also have eight females, Marshall Pass, Colo., 10,856 ft., July 28, 1908.

\section{Hydrophorus magdalenæ Wheeler (fig. 6).}

Male. Occiput bronze-green, with some brownish dust and only two postvertical bristles; front opaque brown; face rather wide, slightly dusted allover, yet with the green metallic ground color showing through distinctly on the upper balf, where the dust is brown; on the lower half the pollen is yellowish white; palpi dark brown pollinose; antennæ rather small, first joint a little stout at apex; cheek narrow, dependent; postorbital bristles about twelve, descending a little below the middle of the eye; beard yellowish, a few black spines under the neck. Thorax golden green, heavily overlaid toward the front with brownish dust, which extends down on the pleuræ and becomes gradually paler; six or seven dorsocentrals, two humerals, four large scutellars; propleura with long yellowish hair and one black bristle; a few microscopic scattered white hairs on the upper end of the sternopleura; halteres yellow; wings moderately broad, veins yellowish at base, the costa becoming black at the tip of the first vein or beyond it. Legs rather bright golden green; front coxæ with rather long whitish hairs and at tip a few small black setæ; front femora with white hairs and a short row of spines on the outer side below at base; on the inner side below a row of spines extending about all the length; tibia on inner side with a row of slanting spines, the apex of the tibia not enlarged toward the femur; all the tarsi blackish, with large, divergent claws and brownish pulvilli. Abdomen quite bright green, with long, almost woolly white hair along the sides extending to the tip in diminishing length; hypopygium concealed, the two flaps that project behind the lower part with rather long and dense white hair; fourth segment projecting V-shape below. Length, $3.5 \mathrm{~mm}$.; of wing, 4.5

The female differs hardly at all from the male. Length, 4.6 mm.; of wing, 5.7. 
Twenty-five specimens: Mt. Rainier, Wash., above Longmire's Springs, Aug. 3, 1905, and Marshall Pass, Colo., July 28, 1908. Compared with cotypes loaned me by the American Museum of Natural History.

I was in doubt about the identification until I had examined the cotypes, as in my material the costa is not yellow so far from the base as in Wheeler's.

\section{Hydrophorus signiferus Coquillett.}

(Copy of original description.)

Female. Upper part of the occiput, front and face opaque, densely brownishyellow pruinose, a small gray spot below each of the facial tubercles; palpi brownishyellow pruinose in the center, the edges gray; proboscis and antennæ black, third joint of the latter subquadrate, slightly broader than long; a notch at insertion of the arista and another opposite it on the lower side of the joint; penultimate joint of arista one-half as long as the last joint; bristles of occiput black, intermixed with a few pale yellow hairs. Thorax blackish, the margins and upper part of the pleura opaque, densely brownish-yellow pruinose (center of the dorsum may have been abraded in the single specimen before me), remainder of pleura white pruinose; scutellum opaque, densely brownish-yellow pruinose, bearing four bristles. Abdomen shining bronze green, the lateral margins and venter white pruinose. Coxæ and trochanters densely whitish pruinose, femora and tibiæ shining, bronze green, the tarsi black; front femora bearing a few short spines on the basal third of the under side. Wings grayish-hyaline, veins bordered with pale brown, a dark brown spot on the hind crossvein and another near the middle of the last section of the fourth vein; third vein toward its apex strongly curving toward the fourth; hairs of lower calypters pale yellow. Halteres yellowish, the knobs brown Length, 6 mm.

Type.-No. 4052, U. S. N. M.

\section{Bering Island, July-August, 1897. A single specimen collected} by Mr. Barrett-Hamilton.

\section{Hydrophorus algens Wheeler.}

Face rather wide in both sexes, only moderately narrowed above, bulging and then receding below, with brownish-yellow dust, which is denser in the male, allowing nothing of the ground-color to be seen; in the female however the metallic blue-green color shows through, but is not very bright. Palpi with brown dust and mostly yellow hairs; front opaque brown; postorbital black bristles in a rather dense row, beard yellow; postvertical bristles only one pair. Thorax with thin seal-brown pruinosity extending down to the middle of the pleuræ, where it changes suddenly (viewed from in front) into glaucous; dorsocentral and acrostichal bristles erect, long and slender, about 10 de in a row. A lighter color in spots between these bristles (in the row) gives the effect of three paler lines on the dorsum; four strong scutellars; propleural one, among yellow hairs; halteres dark brown, stem yellow. 
Abdomen concolorous with thorax, glaucous on the sides to a little above the suture; hairs black above, pale on the glaucous portion; male appendages much retracted in drying, as usual. Front coxæ with abundant yellow hairs on fore side and no black spines at all; front femora only moderately robust, with yellow hair on inner side, long toward the apex in male; underneath at base outside the flexed tibia with four (male) to seven (female) smallish spines of increasing length distally; fore tibiæ almost straight, with a row of slender short spines on flexor side, stronger distally. Wings indistinctly brownish with the two dots plainly visible to the naked eye; none of the veins yellow. Length of male, $4 \mathrm{~mm}$; of female, $3.9 \mathrm{~mm}$.

Redescribed from cotypes, one male and one female, collected by Wheeler at Two-Gwo-Tee-e Pass, Wyo., Sept. 12, 1895. The specimens were loaned to me for study by the American Museum of Natural history.

I have seen no more material in this species. It differs from chrysologus in having fewer spines on the under side of the front femur. Chrysologus is mostly eastern, but I have one male from Boulder, Colo.

\section{Hydrophorus chrysologus Walker.}

Male. Occiput, front, face and palpi wholly seal-brown pollinose, opaque; postorbitals one pair, postverticals about twelve in number on a side, extending down more than halfway behind the eye, beard deep yellow, abundant; cheek very narrow; palpi with brown hairs; antennæ rather small, with no unusual features. Thorax and ablomen deep brown above, somewhat shining; this color extends down on the pleura a short distance, and correspondingly on the abdomen, below glaucous. In one of the two males the abdomen is distinctly more greenish. Scutellar bristles two pairs, humeral two, notopleural two; dorsocentrals much smaller than in pirata, acrostichals minute; propleura with stout yellow hairs and one black bristle; remainder of pleura bare except a few microscopic hairs on the mesopleura; squama brown with yellow hairs; halteres brown, the middle of the stem yellowish. Front coxæ yellowish pollinose on the inner half of the front side, the rest somewhat glaucous, a row of small black spines running up the front outside the middle line; these spines are scattering and irregular; front femora not much thickened, below with two irregular rows of spines of uneven size and between the rows some minute setules; tibia straight, with a row of short rather inclined spines on the flexor side as usual, not ending with a longer spine; the other femora not especially slender nor elongated for this genus. Wings narrow, with black veins, almost byaline with distinct spot on hind crossvein and another beyond it on the middle of the last segment of the fourth vein; these two spots can be seen with the naked eye against a white background. Fourth segment of the abdomen with a V-shaped projection below, more conspicuous in a shriveled specimen than in a normal one; the latter has two long lamellæ hanging down near apex, which are folded in in the other specimen, so the hypopygium does not look like the same structure in the two specimens. Length, $3 \mathrm{~mm}$.; of wing, $3.5 \mathrm{~mm}$. 
Female. Very like the male and about the same size in some specimens; some unshriveled ones a little longer.

Seren males and fifteen females: Crawford's, Franconia and Mt. Washington, N. H. (Mrs. Slosson); New Bedford, Mass., April 20, 1896 (Hough); Provincetown and Eastham, Mass., (C. W. Johnson); Montreal, Quebec, Sept. 8, 1901 (G. Beaulieu); Battle Creek, Mich.; Boulder, Colo.

I at first identified this with glaber Walker, but according to the description that species has yellow halteres. The references in my catalogue under glaber, mentioning its occurrence in Alaska and New Hampshire, are probably this species.

\section{Hydrophorus phoca sp. nov. (fig. \&).}

Male. A small species with brown dorsum and spotted wings. Occiput greenish with only the usual postvertical bristles; front and vertex sealbrown, not shining; face of moderate width, with brown pollen, which is so thin on the upper half that the green ground color shows through very plainly: this part of the face has deep longitudinal corrugations; palpi dark brown; antennæ wholly black, the first joint short, hardly longer than the second; third joint also small; infra-orbital bristles extending down almost to the lower border of the eye, beard yellow, no black bristles below the neck. Thoracic dorsum brown above with two faint rows of lighter spots that intervene between the bristles of the dorsocentral rows; the posterior part of the thorax is damaged by the pin in the described specimen; scutellum rather bright green, with four large bristles; the bristles of the sides of the thoracic disk are much larger than those of the central part; two small humeral bristles; no hairs behind the humerus; propleura with yellow hairs only on its lower part, and above them a rather strong yellowish-brown bristle; no perceptible hypopleural hairs; both halteres missing in the described specimen. Front coxæ with yellow hairs, long above, and only two or three small black spines at tip; front femur thick at base, below with yellow hairs near base and in the same region a short row of only four or five black spines; the front tibia not much curved, almost straight, seemingly with only minute setulæ on the inner side, but in the specimen it is impossible to see the structures here very well; middle and hind femora long and slender. Wings slightly brownish, with a distinct brown spot on the hind crossvein and another on the fourth vein a little beyond, both distinctly visible to the naked eye; all the reins black to the base. Abdomen small and short, greenish above, pruinose on the sides and below, bearing pale hairs below and longer ones on the sides of the first segment above; the fourth sternite has a ridge in the middle, which is split from behind forward.

Length, $3.1 \mathrm{~mm}$; of wing, 4.4 .

One male, collected by the late Rev. Mr. Livingston, at Corfield, Vancouver Island, B. C., dated 8-7-96; from Professsr Melander. 
Hydrophorus parvus Loew. (fig. 3.)

Male. Minute brown species with wholly dark brown halteres. Occiput brown, one pair of postverticals, postorbitals twelve, extending about halfway down the eye; opposite the ocellar tubercle on the orbit an unusually long proclinate and convergent pair of bristles; beard white and rather thin, cheek narrow; no black bristles under the neck; front brown; face narrow above, yellow to brown, entirely opaque, palpi blackish; antennæ of medium size, not elongated, still the third joint protuberant at tip in the middle. Thorax sealbrown above the notopleural suture and glaucous below; two pairs of scutellars, one humeral and one or two hairs; one posthumeral, two notopleural, both large; seven large dorsocentrals in each row; acrostichals small; all these thoracic bristles are comparatively large; propleura with only a few small white hairs and one black bristle; mesopleura with only a few microscopic white hairs, the pleura otherwise bare; halteres wholly dark brown; squama brown, with yellowish hairs. Front coxa white pruinose, with very few white hairs, but a row of black bristles down the front side, largest at proximal end, tapering off into a few white hairs near tip; there are also a few black spines across the tip. All the legs below the coxæ dark green, he tarsi blackish; front femora below with about three stout spines near base, on the inner side with a row of small spines most of the length; front tibia on the inner side with a row of inclined spines, longer distally, but not ending in a prominent spine; middle and hind femora slender, a little bowed. Wing narrow, subhyaline, veins black, first posterior cell not narrowed, last section of fourth vein straight; last section of fifth vein as long as the posterior crossvein. Length, $2.6 \mathrm{~mm}$.; of wing, $3.5 \mathrm{~mm}$

Female. Face brown, narrow; resembling the male very much in all respects. Length, $2.8 \mathrm{~mm}$; of wing, $3.6 \mathrm{~mm}$.

Three males and two females: New Bedford, Mass. (Hough); Hampton, N. H., April 17 and 22 and May 5, 1904 (from C. W. Johnson, collected by S. A. Shaw); Somerset, Mass., Dec. 31, 1904 (from C. W. Johnson, col. by N. S. Easton). The type locality was Illinois.

\section{Hydrophorus pirata Loew.}

Male. Occiput brownish pruinose, with one pair of postverticals; postorbitals about sixteen on a side, descending nearly to the lower edge of the eye; beard rather light yellow; cheek rather narrow; front and face opaque brown, palpi dark brown with black hairs; antennæ of ordinary structure, but the first joint a little elongated. Dorsum of thorax and abdomen sealbrown, this color extending a little below the notopleural suture and correspondingly on the abdomen, the side of the body below being densely white pruinose with a slight glaucous tinge; scutellar bristles two pairs, humeral two, notopleural two, the dorsocentrals much smaller, yet not so small as in some species, about 11 in number, the next to the last largest; propleura with a few delicate yellowish hairs above, some coarser ones below that seem almost brown in certain lights, and one large black bristle; pleuræ with no other hairs except a few microscopic whitish ones on mesopleura; squama brown with yellow hairs; halteres with brownish stem and very dark, almost black, knob. 
Front coxæ with a row of about sixteen black bristles on front side, more slender and delicate above, and with rather dense hairs on the mesial side of the row; femora and tibiæ somewhat shining green, the former only moderately thickened at base, below with a scattering row about ten short spines on the inner side, extending the whole length, and on the outer side six or seven forming a row on the basal half; tibia with a row of spines on the inner side, not erect nor enlarged at tip, and the tibia is not bent toward the femur at apex. The middle and hind femora bright green, rather slender. Wings a little infuscated, with black veins, a slight cloud on the hind crossvein, not very apparent but constant. Abdomen showing a little green above, the sides of the two basal segments with rather woolly brown hair; hypopygium mostly concealed. Length, $4 \mathrm{~mm}$.; of wing, $4.9 \mathrm{~mm}$.

Female. All that I have seem to have the abdomen shortened in drying, otherwise not differing from the male. Length $3.6 \mathrm{~mm}$; of wing, $5.1 \mathrm{~mm}$.

Fourteen specimens both sexes: Franconia and Crawford's, New Hampshire, (Mrs. Slosson); New Haven, Conn., Oct. 21, 1903 (C. W. Johnson, collected by H. L. Viereck); Danvers, Mass., Sept. 23 (C. W. Johnson); Montreal, Que., Sept. 1, 1901 (G. Beaulieu).

In some specimens there is a distinct metallic reflection on the upper half of the face when the light comes from straight in front or a little below.

\section{Hydrophorus extrarius sp. nov.}

Female. Occiput moderately shining green, with one pair of postverticals; postorbitals about fifteen, descending hardly to the middle of the eye; cheek very narrow, beard white; no black bristles below the neck; front brownish pollinose. in some lights dark greenish; face rather narrow for the sex, somewhat pollinose all over, yet on the upper, concave part a dull green shows through the brown dust; lower convex part of the face with dense brown dust in the middle, and whitish on the sides; palpi gray, with mixed whitish and black hairs; antennæ of plain structure, a little longer than in some species. Thorax rather seal brown above, brighter green behind; at the notopleural suture this changes to glaucous; scutellar bristles two pairs, notopleural two, humeral two rather small, dorsocentrals fairly well developed but slender, acrostichals except at extreme front of the same size as the last. Propleura with white hairs and one black bristle; sternopleura with only a few microscopic pale hairs; squama yellow with whitish hair; halteres yellow, with a large brown spot on the knob. Front coxæ glaucous, with dense, short white hair in front and no black spines except two or three short ones at the tip; front femur not very much enlarged, below with a short row of five or six spines on the outer side at base and another short row on the inner side toward the tip (in one specimen a few small scattering spines continue this inner row toward the base more than in the other one); front tibia straight, with the usual row of small spines on the inner side quite slanting, not enlarged toward tip; middle and hind femora rather slender and a little bowed; wings almost hyaline, unspotted, veins 
black at base, third and fourth veins not appreciably convergent at tip. Abdomen rather bright bluish green, glaucous underneath, hairs of the bright part black, of the glaucous part white. Length, $3.8 \mathrm{~mm}$; of wing, $5.1 \mathrm{~mm}$.

Two females: Brookings, S. D. (type) and St. John's, Quebec, Aug. 8, 1901, the latter collected by G. Beaulieu, his number 46.

I hesitated a long time before describing this species. After long consideration I satisfied myself that it is recognizably distinct, even in the female sex alone, so for the sake of completeness I give it a name. Its relationships are with pirata perhaps more than any other species, but the absence of procoxal spines and the different color of the face, with other characters, are sufficient to distinguish it.

\section{Hydrophorus innotatus Loew.}

Male. Occiput green, with brown dust, not bright, only two postverticals; front opaque brown; face bright green above with only a little brown pollen, changing to white above the suture and densely covering the lower half; palpi brown; cheeks forming narrow flaps; the black postorbital hairs about 18 in number, descending two-thirds of the way to lower edge of the eye; beard yellow, dense, mixed under the neck with a few black spines; antennæ short and small, first joint hardly larger than second. Dorsum of thorax and abdomen rather uniform sealbrown; scutellars two pairs, acrostichals in a rather dense row, dorsocentrals slender in front, the posthumeral strong; pleuræ glaucous except irregularly along the upper part, where they are brown like the dorsum; propleura with yellowish hairs and one large black bristle; halteres with brownish knob; wings hyaline, veins black. Front coxæ glaucous, with very small white hairs and a conspicuous row of black bristles, about seven in number, longest at the base, placed rather on the outer side of the member; these bristles do not quite reach to the apex, but after an interruption there are more placed somewhat transversely across the tip; front femur below with a row of short but stout spines on the inner side, smallerand irregularly placed near the base, and on the outer side a row consisting of three or four rather large spines at base and beyond them as many more notably large, long ones, standing far apart, the last a little beyond the middle; front tibix with a very regular row of small inclined spines, not larger at tip, where the tibia curves slightly toward the femur; the other legs of plain structure. Abdomen short, brown down on the sides almost as far as the suture, glaucous underneath; hypopygium small, fourth sternite projecting V-shaped, this and the lobes of flaps behind bordered with whitish hairs; sides of abdomen with yellowish hairs near base.

Length, $3.7 \mathrm{~mm}$.; of wing, $5.2 \mathrm{~mm}$; the latter indicates that the specimen is abnormally shortened in drying, or else has naturally a very short abdomen.

The female has a wider face, and the dust is wholly brown on the lower part, except just below the suture on each side, where it shows a tendency to a white spot as in signiferus. This is largely a matter of the direction of the light. Halteres distinctly brown on the knob, rather more so than some males. Length, $4.1 \mathrm{~mm}$.; of wing, $5.2 \mathrm{~mm}$. 
Twelve specimens, both sexes: Beaver Creek, Newport, Oregon, Aug. 13, 1902; Keyport, Wash., Aug. 7, 1905; near Seattle, no date; Bellingham, Wash., July 29; Lyndon, Wash,. July 29, 1908. The last two lots mentioned are from Professor Melander, and the preceding one from Prof. O. B. Johnson. The type locality of the species was Sitka. Loew's description is easily recognizable and there can be no doubt of the identification.

\section{Hydrophorus altivagus sp. nov.}

Male. Occiput bright metallic green with faint brownish pruinosity; postverticai bristles one pair; postorbitals about fourteen on a side, extending a little over halfway down the eye; beard yellow, no black bristles below the neck; cheeks wide; front brownish pollinose, not much shining; face bright green on the upper fourth. the rest white pollinose; palpi strongly contrasting dark brown, with black hair; antennæ short, of ordinary form. Dorsum of thorax rather dark bronze-green, moderately shining; upper part of pleura concolorous with the dorsum for a narrow space; scutellar bristles two pairs, humeral two, notopleural two; dorsocentrals comparatively large for the genus, the penultimate one almost as large as the scutellars; propleura with long, delicate yellow hairs and one strong black bristle; mesopleura with a few microscopic pale hairs; squama yellow with yellow hair; halteres almost black, the stem yellow in the middle. The pruinosity of the pleura is almost white. Front coxa with abundant yellowish hairs on the anterior side; five or six black spines at tip and a row of black spines, four in the described specimen, running up the outer front edge from the tip about half way to the base; front femur moderately thickened, ou the inner side below with seven stubby spines forming an irregular row the entire length, ou the outer side below there appear to be only two or three short spines at base; front tibia straight, with the usual row of small spines on the inner side; they are not erect, and are very uniform; middle and hind femora shining blue-green, not very slender. Wings large and rather broad, subhyaline, veins black, unspotted. Abdomen rather bright bronze-green above and on the sides almost to the suture, the rest whitish pruinose; hypopygium more concealed than usual. Length, $4.7 \mathrm{~mm}$; of wing, $5.1 \mathrm{~mm}$.

Female. Face with yellowish-brown dust below, on each side below the suture changing to gray; palpi as in the male, blackish; front coxæ with one spine above the tip or none (this is evidently a variable character); spines on under side of front femur as in the male but somewhat longer. Length, $4.8 \mathrm{~mm}$; of wing, 5.6 $\mathrm{mm}$.

One male, Marshall Pass, Colo., Alt. 10,856 ft., July 29, 1908; three females, Boulder, Colo., August, 1897.

Hydrophorus amplectens sp. nov. (figs. 8, 13).

Male. Postorbital black bristles about twenty-six in number, extending almost down to the lower corner of the eye, postverticals only two, beard pale yellow, cheeks exceedingly narrow; occiput green, front sealbrown, face rather narrow, 
shining green above, on the lower part with brown dust; palpi dark brown with blackish hairs; antennæ plain, small, first joint not elongated; underneath the neck among the beard are rather numerous black bristles. Dorsum of thorax shining sealbrown, green before the scutellum and around the humeri, the acrostichal and dorsocentral bristles very small and thin and rather numerous; even the hindmost dorsoccntral is thin and small; scutellars four; upper part of the pleura quite pure green, lower part glaucous pruinose, few almost imperceptible microscopic hairs on the upper part of the sternopleura; propleura with pale yellow hairs and one black bristle; halteres brown on the outer side of the knob; front coxæ with fine brownish hairs on the front side and small black spines at and above the tip; front femora not much thickened, with a single row of bristles below along the middle, about nine to twelve in number; near the tip below there is a prominence followed by an excision; just back of the prominence is a close row of five stiff and bluntly pointed spines; on the front tibia at the base is a slight lateral prominence about opposite the excision in the femur, surmounted with minute spines; following this to the apex is the usual row of small, rather erect spines; the effect of the excision and both prominences is evidently to form an organ for holding the female. The other legs of plain structure, except that the last two joints of the middle tarsi are black and somewhat flattened, the fifth joint more so than the fourth. Wings of moderate wilth, subhyaline, the veins black, with almost imperceptible spot on the hind crossvein and another beyond (in one specimen these are considerably stronger). Abdomen bright bluish green, glaucous only below and on the under part of the sides; fourth sternite emarginate behind and the space occupied with a large black organ which seems to end in a thin edge behind, quite different from most species. Length, $4.2 \mathrm{~mm}$; of wing, 4.8 .

Female. The face is much wider, front and middle legs of plain structure. Front femur below with loose brown hairs and toward the tip a small spine or two. One female has the two spots of the wings more developed than the rest, but still faint. Length, $4 \mathrm{~mm}$., of wing, $5.1 \mathrm{~mm}$.

Three males and two females, all taken at Brookings, S. D.; three were captured in early spring of 1890 . One male, Battle Creek, Mich., summer of 1897.

The female differs from that of magdalence in having much shorter dorsocentrals, no row of spines under front femur, and a brown spot on knob of halteres. The male differs in the structure of the fore legs and in having a narrower face, as well as in the smaller dorsocentrals.

Hydrophorus pensus sp. nov. (fig. 7).

Occiput shining green, only one pair of post verticals, the postorbitals about twelve in number, extending down only about one-third the height of the eye; beard white; no black bristles under the neck; cheek below the eye exceedingly narrow; front dark brown, hardly at all greenish; face narrow above, smooth and brilliant blue, below covered with white dust; palpi concolorous, with pale hairs; eyes with 
larger facets just below the antennæ; antennæ of medium size, not quite so short as in some species, arista rather long. Dorsum of thorax sealbrown in front, green behind; four scutellars, two humerals, dorsocentrals of moderate size, the hind ones rather strong; pleuræ wholly white pruinose, bare, propleura with white hairs and one black bristle; squama blackish with pale hairs; halteres yellow with brown spot on knob and brown root. Front coxæ white pruinose and with fine soft hair, at tip sometimes with a few small black spines, sometimes without these; front femur with an irregular row of spines below, larger and smaller mixed and toward the tip on the inner side two or three longer ones; front tibia straight, with a uniform row of nearly erect, even, small spines on inner side; middle femora long and slender, a little bowed; hind femora also long, not so slender, beyond the middle with numerous dense, curved bristles below; the femur tapers rapidly near the tip, almost excised below; all the claws and pulvilli small. Wing narrow, almost hyaline, unspotted, veins blackish. Abdomen bright green, with two long, brownish lamellæ projecting forward underneath, about half as long as the abdomen; fourth sternite bent forward in a $V$-shape. Length, $3.2 \mathrm{~mm}$.; of wing, $4 \mathrm{~mm}$.

Female. Face wider than in male, but still narrowed below the antennæ; about fifteen postorbitals on a side; hairs on palpi blackish; a few pale microscopic hairs on sternopleura. Length, $4.9 \mathrm{~mm}$; of wing, $5.4 \mathrm{~mm}$.

Forty specimens, both sexes: Craig's Mt. Idaho (type), June, 1894; Moscow, Idaho, May 3, 1895; Potlatch, Idaho, June 20, 1907; Troy, Idaho, Sept. 26, 1896; Harrison and Juliaetta, Idaho, and Pullman and Seattle, Wash.

This appears to be the commonest Hydrophorus of the Pacific Northwest.

\section{WaLker's Species.}

Under the name of chrysologus on a preceding page I have described a species which may be the one to which Walker gave that name, although there is no great certainty about the matter. His description of glaber offers no characters of significance different from that of chrysologus, except that in the former case he mentions the dark knob of the halteres, while in the latter he calls the halteres yellow, very possibly overlooking an infuscation of the knob. The two spots on the wing occur in both descriptions, and with the item about the halteres include almost all of distinctive importance. I know no spotted-winged species with wholly yellow halteres, though in phoca the question is yet open, owing to the loss of both halteres in the single described specimen. If the face is shining in chrysologus, it might be the same as algens, but the ambiguous expression used seems to indicate an opaque face: "head covered with golden bloom, 
which is paler and brighter toward the mouth." The two descriptions of Walker may really refer to the same species, assuming that the brown spot on the knob of the halteres was overlooked in glaber.

Walker's alboflorens seems to approach pirata, having infuscated halteres and unspotted wings, but so many characters are omitted or vaguely mentioned that a decision is impossible.

His viridiflos has been identified with my intentus, but as I understand the expressions used, it is much more nearly related to aestuum, a widely different species. At least it is a small eastern species with the wings pale at the base.

These conclusions will show the uselessness of trying to "do something" with Walker's names. If anything, I have gone too far in assuming that I have identified one species. An examination of Walker's types is the only process that will settle the matter; even that will have only a bibliographical value, and will not advance entomology in the least, assuming that we already know all of his species under some name, which is highly probable. I have heard of one entomologist who in recent years did in fact examine a part of Walker's types of Dolichopodidæ, and who had the self-restraint on coming home to say nothing about what he found, deeming it best not to disturb existing nomenclature. And he is a man who has contributed vastly to entomology in more than one order.

\section{THE DIPTEROUS GENUS DIOSTRACUS LOEW.}

(Pl. 8.-figs. 15-18.)

By J. M. Aldrich,

The University of Idaho, Moscow, Ida.

The genus Diostracus was founded by Loew in his Neue Beitrâge, VIII, 43, 1861, and redescribed in Monographs, II, 120, 1864; the entire second notice is merely a translation of the first, both as to the genus and the single species, with the addition of one or two unimportant comments. ${ }^{1}$ The typical and sole species, prasinus, was collected by Osten Sacken in New York, presumably near New York City. It has apparently not been collected since

1 Note.-On page 122 of the monograph, the expression regarding the middle tarsi, " the first joint about as long as the other three taken together," should have been translated "the first joint about as long as the following three," etc. 
the time of its discovery; at least, there are no references to it in literature, and I have never seen it in any collection examined by me. The discovery of a second species in the Puget sound region enables me to add some chaetotactic characters, and for convenience I redescribe the genus.

Generic characters.-Male. Antennæ of medium size and simple form, first joint moderately elongated, hairy above, the second short, hairy above and below, the third short with a rounded tip and almost basal arista, which is of medium length and has a very short pubescence. Face wide, short, with a strong transverse suture, the lower part ending in a point in the middle; palpi very large, folded loosely across the front of the large, bulky proboscis, which extends broadly up under the neck. Occiput convex, nearly horizontal above, with a row of orbital bristles extending to the mouth and only sparse beard below; postvertical bristles two, verticals two, as large as the ocellar. Thorax with absolutely no small hairs on the dorsum except at the extreme front edge; no acrostichals; six strong pairs of dorsocentrals; scutellars one pair and several hairs on the edge; humeral one and a few hairs; notopleurals two; posthumeral one; supra-alar two; postsutural one or two small; propleural one rather weak; a row across the first abdominal segment. Pleura bare. Metanotum large, nearly horizontal. Abdomen with six visible segments dorsally besides the hypopygium, which is small but not much embedded; fourth sternite bent out in a $\mathrm{V}$-shape. Hind metatarsuslonger than following segment; hind coxa without an erect bristle on the outside. Wings rather long, third and fourth veins nearly parallel, ending in the apex, second vein ending a little before the apex, hind crossvein less than its length from the hind margin.

Female. Face still wider, palpi not quite so large, more pointed and hairy. Two good-sized postsuturals.

It will be observed that the added generic characters are not drawn from the type species; but the close correspondence of the new species with the type in all essential known characters of the latter makes it highly probable that the type shows these newly mentioned ones also. The relationships of the genus are evidently with Thinophilus, as stated by Loew; five species of Thinophilus examined by me all agree in having no acrostichals, but differ from Diostracus in having the first antennal joint bare and shorter, and in having one notopleural bristle instead of two. In most of their characters, including the large palpi, the two genera are much alike.

\section{Diostracus olga sp. nov.}

Male. Occiput thickly gray pollinose, showing only a little greenish ground color; postorbitals rather scattering, black, the row extending to the mouth; beard of only a few yellowish hairs; front short and wide, gray pollinose, ocellar tubercle 
prominent; face grayish above the prominent suture, shining green below it; palpi large, yellow in ground color, with snow-white shining luster on the outer side, which has only a few hairs, of a yellowish-brown color, mostly along the upper or. front edge; eyes prominent and rounded, extending much below the side of the face, but not much below the pointed middle of the face; antennæ wholly blackish, as described under the generic characters. Thorax pure bright green above, not very shining, with two narrow brown lines extending from the front almost to the scutellum, close together, also a long and rather wide brown spot on each side, extending about equally before and behind the suture; humeri and a stripe above the notopleural suture pruinose with whitish; pleura wholly covered with a thin greenish-gray pruinosity, which also covers the metapleura; propleura with a brownish bristle and one or two hairs; squama brownish, with yellowish hairs; halteres yellow. Coxæ and legs blackish, with little greenish luster, the tips of coxæ, the trochanters and extreme base of femora yellow, tips of femora and bases of tibiæ also yellow; front coxæ with thin white hair on front side and a few black bristles at tip; all the femora quite destitute of bristles except a preapical one on the middle and hind ones; tibiæ plain, with ordinary bristles; tarsi plain, with small pulvilli and empodia. Wings uniformly infuscated, the veins dark. Abdomen short, grayish-green, not shining, with black hairs, which attain the size of bristles only along the hind edge of the first segment, especially toward the sides; hypopygium with two black lamellæ hanging down from posterior part. Length, $4 \mathrm{~mm}$; of wing, $5 \mathrm{~mm}$.

Female. Face wider, not very shining, rather grayish-brown below the suture, the palpi more pointed than in the male, covered with coarse black hair and grayish pollen, which is paler along the lower edge. The postsutural bristles are uniformly larger than in the male, always two on each side. Length, $4.9 \mathrm{~mm}$.; of wing, $6.1 \mathrm{~mm}$.

Three males and three females, collected by myself near Olga, Orcas Id., Wash., July 14, 1909. One male, collected by Professor Melander near the same place, July 28, 1909.

All the specimens were taken on rocks along a little brook in a very shady place.

The wholly yellow legs of prasinus, among other characters, easily distinguish it from olga.

\section{EXPLANATION OF PLATE.}

Fig. 1. Hydrophorus cerutias Loew, wing of male.

2. " " phoca sp. nov. wing of male.

3. " " parvus Loew, wing.

4. " intentus sp. nov. back of head, showing supernumerary postvertical bristles.

5. " c cerutias Loew, side of head of male.

6. “ magdelence Wheeler, side of head showing wide cheek.

7. “ pensus sp. nov. abdomen and hind femur of male. 


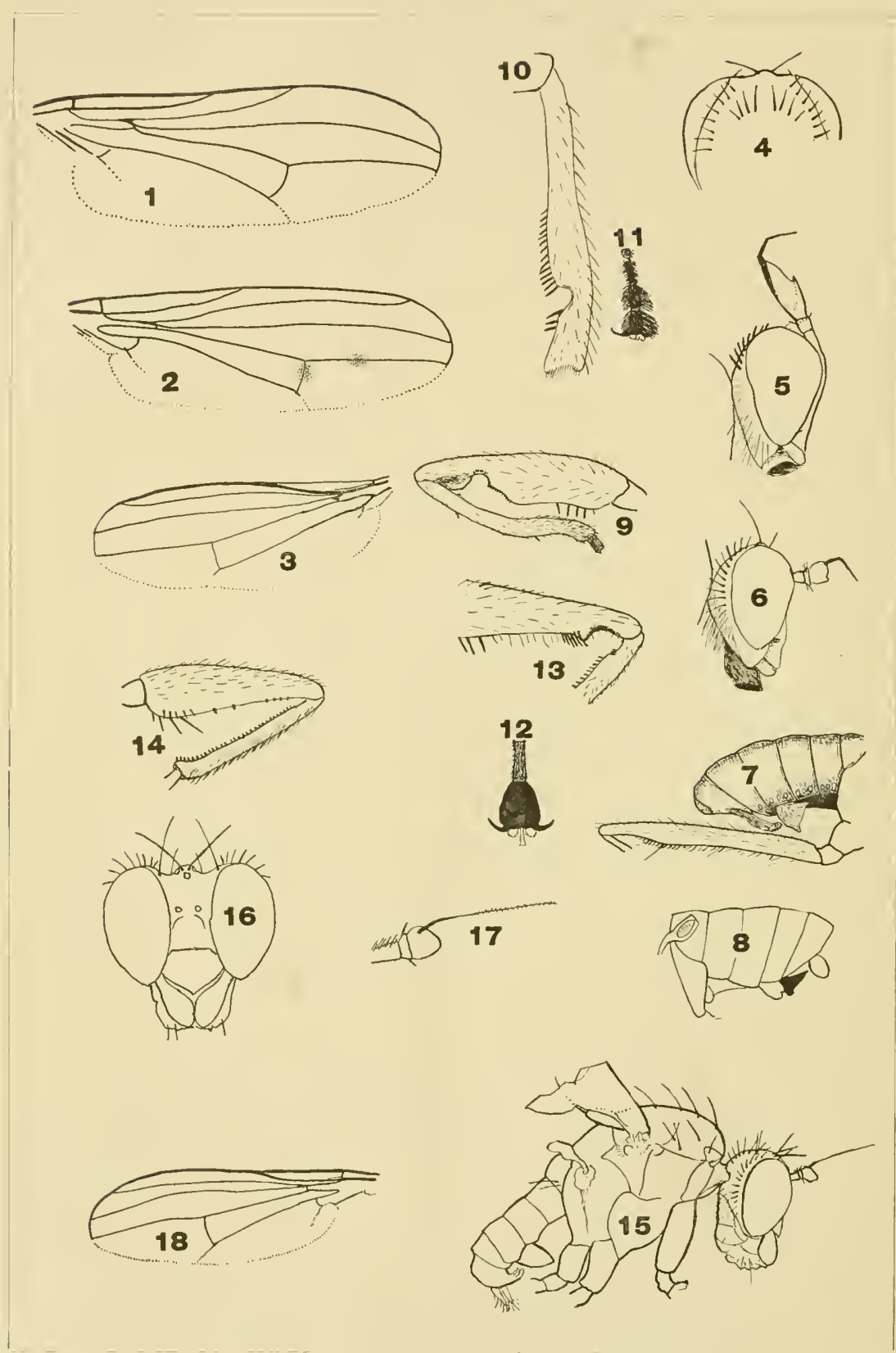

ALDPICH. - NORTH AMERICAN HYOROPHORUS AND DIOSTRACUS. 
Fig. 8. Hydrophorus amplectens sp. nov. side of abdomen of male.

9.4 canescens Wheeler, front femur and tibia of male.

10. " " breviseta Thomson, front tibia of male.

11. " " " upper view of tip of left middle tarsus, male.

12. " agalma Wheeler, upper view of tip of middle tarsus, male.

13. " amplectens sp. nov., part of front femur and tibia of male.

14. “ philombrius Wheeler, front femur and tibia of male.

15. Diostracus olga sp. nov., side view of male.

16. " " " " front view of head of male.

17. " " " " " $"$ " antenna of male outer side.

18. " " " wing of male. 





\section{New Genera and Species of Dolichopodidx.}

BY J. M. ALIRICH.

\section{Dactylomyia.}

New genus (Gr. dalitulos, finger, toe; muir, 11y).

Face narrow, slightly wider above and below, a transverse suture sets off the lower third from the upper portion. The antenna are inserted high up, making the front exceedingly short. Antennx small, very short, the three joints crowded together; third joint oval with apical or subapical arista; first joint bare above. Occiput convex, the cilia of the inferior orbit becoming scattered and irregular near the mouth. Acrostichal bristles in two rows; a sub-quadrate, slightly impressed spot before the scutellum, the latter with but two bristles. Abdomen short, and strongly arched downward, only partially metallic in color. Hypopygium large but short, bent forward under the venter; it has no lamella or projecting parts but is a globose structure with a wide opening anteriorly. Fore coxa very long. All the legs exceedingly long and slender, the tibiæ longer than the femora, and the tarsi longer than the tibix. Hind metatarsi not shortened. WVings slender, not narrowed basally, the cross-vein nearly in the center, oblique, distant twice its length from the margin (on the fifth vein); the third and fourth veins gradually converge beyond this point and end near together, the fourth decidedly before the apex; just before the end they are nearly parallel.

This genus has the longest legs of any in the family, that I have ever seen. The hind leg is a trifle over twice the length of the whole body, and the others scarcely less. The wing venation reminds of Medeterus, and the habits are the same, both being found on the bark of trees; but the legs, face, hypopygium, etc., are different.

\section{Dactylomyia gracilipes, $\mathrm{n}$. $\mathrm{sp}$.}

Male. Face long and narrow, slightly wider above and below, silvery white pollinose. Palpi and proboscis yellow. Front covered with grey pollen. Antenua yellow, tip of third joint slightly brownish; arista subapical or very nearly apical. Cilia of inferior orbit white. Dorsum of thorax green with thick brownish-grey dust; the posterior impressed area bluish. Pleura green with white dust. Halteres and cilia of tegulae pale yellow. I'osterior margin of the pleuræ pale yellow. Abdomen shining blue-green, the anterior edges 
of the segments, particularly the second, more or less yellow, usually showing this color only along the sides. Venter yellow. Sixth segment and hypopygium wholly yellow. Coxæ yellow, the anterior ones, very long, with a thin row of pale hairs in front; the intermediate ones brownish at the extreme base; posterior ones with a single dark bristle on the outer side. Legs and feet wholly yellow; the front tibiæ slightly longer than their femora, the first two joints of the fore tarsi are elongate and slender, together longer than the tibia; the remaining three joints very short, subequal. Middle and hind legs and feet simple, but exceedingly slender. Wings hyaline with yellow veins, sixth vein almost obsolete.

Female. Face scarcely wider; antennæ a very little shorter; fore feet fully as long as in the male, but the joints successively shorter, as usual. In both sexes the middle metatarsus is longer than the tibia.

Length, $2.5-2.8 \mathrm{~mm}$; of wing, $3 \mathrm{~mm}$.

Numerous males and females, Brookings, South Dakota. Common in July on the trunks of trees. I collected it on willow, cottonwood, and box elder. A single male from Florida, sent me by C. W. Johnson, does not seem to be specifially distinct.

\section{Metapelastoneurus.}

New genus.

Male. Face wide, convex below; antennæ short, the third joint rounded, with a dorsal, plumose arista; fourth vein of the wing bent forward near its tip, ending but a little distance behind the third; hypopygium exserted, about as long as the fifth abdominal segment, bent forward under the venter; at its tip prolonged into four filaments which reach the posterior coxæ.

The only essential difference between this genus and Pelastoneurus is in the structure of the hypopygium. The basal segment of the organ in a typical Pelastoneurus (vagans) is long and slender, and the central portion is also somewhat slender. Besides the small hook-like processes at the tip, - the true grasping organs-the hypopygium also bears two narrow fringed lamella, arising from the tip at the edge which would be called dorsal were the organ extended behind the abdomen. These lamellæ are homologous with those which are so conspicuous in the genus Dolichopus.

In Metapelastoneurus, the hypopygiun differs from that just described in being very short and compact in structure. The basal segment is embeded in the abdomen, instead of forming a peduncle. The central portion is thicker and a third shorter than that just described. The lamella, however, are most modified of all the parts, 
each being divided close to the base into two long filaments. The dorsal (as above) one of these is somewhat more heavily fringed and a trifle longer than the other, and bears near the base on the ventral side a slight protuberance, surmounted by a tuft of hairs.

\section{Metapelastoneurus Kansensis, n. sp.}

Male. Palpi yellow, face silvery white, front violet bronze, cilia of inferior orbit black. Antenna yellow, third joint brownish at tip; arista with fine, sparse hairs. Dorsum of thorax shining green, with bronze and somewhat violet reflections; a silver spot in the ante-alar groove, below a bronze stripe. Pleuræ silvery pollinose, over a green ground-color. Cilia of tegulæ dark, halteres yellow. Abdomen shining green, the sutures bronze, and the sides somewhat white pollinose. Hypopygium blackish, the slender filaments brownish, fringed with delicate yellowish hairs, longer toward the tip. 1,egs yellow, plain, the middle and hind coxa blackish except at tip; middle and hind tarsi somewhat infuscated toward the tip. Wings distinctly infuscated, venation the same as in the common Pclastoneurus a'agans Loew.

Length, $3.5 \mathrm{~mm}$. ; of wing, $2.6 \mathrm{~mm}$.

New Males, IVestern Kansas, (University of Kansas collection).

\section{TABLE OF SPECIES OF SYMPYCNUS.}

1. Fourth longitudinal vein ending before the tip of the wing,$\ldots \ldots \ldots \ldots \ldots \ldots \ldots$ tertianus, Loew. Fourth longitudinal vein ending at the tip.......... 2

2. Antennae entirely black,..............frontalis, Loew.

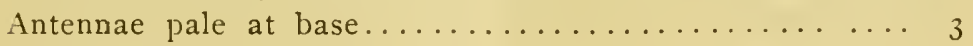

3. Thorax with longitudinal lines............ lineatus, Loew.

Thorax without longitudinal lines.............. 4

4. Arista of male with a small lamella at tip.......nodatus, Loew.

5. Arista of male plain................ occidentalis, n. sp.

\section{Sympycnus occidentalis, $\mathrm{n}$. sp.}

MaLE. Head rounded, the eyes contiguous or apparently so on the face, palpi yellow, minute; antennae inserted very high up (as in all the genus), making the face long and the front short. The front is slightly excavated, covered with grey pollen. First joint of antenna long and slender, brownish-yellow; second joint brown, short, extending in a roundish projection along the inner side of the following joint; third joint as long as the first, oblique in shape, the upper and lower edges parallel, and the tip almost squarely truncate; on its inner side the lobe of the second joint reaches nearly to the middle; the 
arista arises from about the midlle of the upper edge, and is scarcely longer than the three joints taken together. Cilia of the inferior orbit pale. 'Thorax short and romuled, brownish black, not shining, with stout black bristles above, cilia of the tegular pale. Dorsum and pleurae grey pollinose. Halteres yellow. Abolomen slender, clavate, the first segment brownish, the second yellow, the third redelish brown, the following ones passing into black. Hypopygium black, but little protruding, the sidles of the first abclominal segment have a few widely divergent yellow hairs. Coxae yellow, the middle ones brown at base, the leaf-like upper extension of the hind ones (metathoracic epimera, Loew, Monogr. Dolich., p. 96) also yellow. Legs and feet yellow, the latter only a little darker toward the tip (hind feet missing), the fore tarsi are longer than their tibiae; the first joint comprises nearly half the length, and has on the lower surface near the base two or three noticeable hairs; the second joint one-third as long, thickenel; the following joints slencler, short, of equal length. 'The middle tarsus is plain, slender, once and a half as long as its tibia. Hind femora and tibiae plain. Wings yellowish, very broadly romded at the tip, and narrowed towards the base; the third and fourth veins beyond the cross-vein are parallel, then the latter gently approaches the former, then they continue parallel to the end.

FEalali, Face rather wide, wholly grey clusted; antennac inserted as in the male, the first joint lengthened a little less, and the third joint smaller, rounded. Ablomen wholly yellow, verging somewhat into brown. lecrs plain. Wings not broalened at tip nor narrowed basally.

l,ength, $3-3.5 \mathrm{~mm}$; of wing, $2.5-3 \mathrm{~mm}$.

Two specimens-male and female - Wyoming (University of Kansas collections.)

\section{Additions to my Revision of Hygrocelenthus and Dolichopus,}

(in the K. L. (Marter!y for Juily, $18_{93}$.)

\section{Hygrocelenthus idahoensis, n. sp.}

Mats. Face mollerately wirle, snow-white pollinose; palpi yellow; front shining green. Antennae black, not larger than in an average Dolichopus, but the first joint with a swollen yellow protuberance on the inner side; the second joint also slightly yellow on the inner side; arista rather stout. Cilia of inferior orbit snow-white, flattened, conspicuous. Dorsum of thorax shining bluish green, the dark stripe above the root of the wing almost wholly absent; pleurae green, with thin dust; cilia of tegulae pale, not large. Abdomen bright bluegreen, with rather stout bristles along the posterior margins of the 
segments; no yellow hairs on the sides. Hypopygium green at base, black distally; the lamellae are small, white, rounded, with a rather wide margin of black along the apex, where there are the usual curved bristles. Fore coxac yellow, on the outer posterior part a greenish black stripe; on the anterior side with silvery dust and a few dark hairs along the lower part. Nidelle and hind coxac black, the former with yellow tips. Hind trochanters black, the mirldle ones with a black spot. Femora and tibiac yellow, all the tarsi infuscated from the tip of the first joint; fore tarsi simple, about as long as the tibiat; the preapical bristle of the hind femur is the last ancl largest of a series of bristles, beginning near the base of the femur.

Wings hyaline, the anterior part a little yellowish, and the crossvein slightly clouded. The shape is loroad, with an incision at the tip of the fifth vein. The fourth vein ends luefore the ajex; it has a molerately strong curvature. Costa with a long, strong swelling near the tip of the first vein.

FEMALE. Face broad, greyish-white; antennae as in the male; cilia of tegulac larger than in the male, black, with a slight arlmixture of pale. Wings narrower, less yellow anteriorly, costa not thickened.

Length, $5.2 \mathrm{~mm}$; of wing, $4.8 \mathrm{~mm}$.

About 75 specimens, both sexes.

Common at Moscow, Iclaho, in September, at the edge of streams.

I have deposited a set of types in the University of Kansas collection.

In both sexes this species is distinguished from crenatus, O. S., by having plain, short antennae. The male differs from affictus, O. S., in lacking the yellow fringes on the abdomen, while the female of the former has a rather less abrupt curve in the fourth vein, but is very much the same in other respects.

\section{Hygroceleuthus latipes, Lor:w.}

I found this specimen very abundant at I,ake Mills, Wisconsin, in August, on the bare inud adjoining water. In some places they seemed almost to cover the surface.

Hygroceleuthus crenatus, Ost.n Siackrn.

Abundant at Moscow, Idaho, in September, along the edge of water. The specimen of which I figurer the antenna in my previous article is not far from typical, although I there referred to it as a variety.

Dolichopus tenuipes, n. sp.

Male. Face rather narrow, yellow pollinose, below more grey; palpi yellow; front green, with yellow dust; antennae moderately 
long, the first two joints yellow, the third brownish or blackish. Cilia of inferior orbit pale. 'Thorax green, thickly dusted with yellow, not very bright. Above the root of the wing but little brown. Pleurae blackish-green, rather thinly dusted. Cilia of the tegulae black. Abdomen green, before the incisures more coppery, on the sides white pruinose. Hypopygium green basally the remainder black, the lamellae white, ovate, the apex with an ill defined black area, the apical bristles far less strong than in most of the species. Coxae yellow, the hind and midclle ones considerably blackened at base; the anterior side of the fore coxae is thinly silvery pollinose, the lark hairs very minute except near the apex. The first joint of the fore tarsi is yellow, slencler, not very long; the second joint is longer, exceedingly thin and flattened, bare above and below, the edges however with small hairs; the third joint is like the second in structure, as long as the first; fourth joint very small and short; fifth black, compressed, oval in outline, nearly as long as the third, the claws however are attached near the base, so the greater part of the length is a disclike elongation beyond the claws. Beyond the first joint the color is dark. The total length is twice that of the tibia. Middle and hind tarsi each once and a half the length of its tibia, pale at base. Wings long and rather narrow, costa scarcely thickened, veins yellowish.

FEAlale, Face broad, greyish-yellow pollinose; third joint of antennae reddish-brown or brownish, the tarsi simple, about one and a third times as long as their respective tibiae.

Length, $5.2 \mathrm{~mm}$; of wing, $4.7 \mathrm{~mm}$.

Moscow, Idaho; nineteen males and fourteen females. Common at the edge of water in September. I have deposited a set of types in the University of Kansas collection.

I have recently sent to the Amcrican Naturalist an account of the courtship which occurred in the two preceding species.

This Dolichopus cliffers from all the known species in the construction of the fore tarsi in the male; with grandis Ald. it shares the distinction of being the only species with the second joint of the male fore tarsi longer than the first.

\section{Dolichopus setifer, Loew.}

Four males, five females, Lake Mills, Wisconsin, August. The black spot in the tip of the wing of the male is an easy distinguishing mark of this species. Collected at edge of water,

Dolichopus ovatus, Loew.

Numerous specimens, collected with the preceding. 


\section{Dolichopus duplicatus, AIdrich.}

Kansis University Quurterly, Ju!̣, 1893, p. 18

Nine males, five females, Moscow, Idaho, at edge of water in September. The females are not distinguishable, except by a slightly larger size, from those of tenuipes Ald. The male lamellae, which I could not well make out in the type, are very peculiar. The apical lobe is incised all along its outer border so as to have a sort of fringe of a dozen or more narrow divisions, upon the tips of which are delicate hairs. The strong curved bristles are entirely absent.

Dolichopus ramifer, Loew.

One male, Moscow, Idaho, September.

ERratA: P. I53 midway, for New Males, read Two Males; p. I 54 in sub-titles, for Hygrocelenthus, read Hygroceleuthus. 



\section{THE}

\section{AMERICAN NATURALIST}

A Monthly JOURnal DEvoted to THE NATURAL SCIENCES IN THEIR

WIDEST SENSE

\section{REPRINT}

FROM

VOL. XXXIII, No. 394. OCTOBER, I 899

BOSTON

GINN \& COMPANY

The athenxum press

1899 



\section{A BALLOON-MAKING FLY.}

\section{J. M. ALDRICH AND L. A. TURLEY.}

ON June 16 of this year, while passing along a country road near Moscow, Idaho, our attention was attracted by some bright white objects moving to and fro in the air at an elevation of eight or ten feet. A second look seemed to indicate that these objects were connected with small insects. On capturing the insects they were found to be males of a species of Empis, each carrying between its hind feet a peculiar structure which is referred to in the title as a balloon. This is of elliptical shape, about $7 \mathrm{~mm}$. long (nearly twice as long as the fly), hollow, and composed entirely of a single layer of minute bubbles, nearly uniform in size, arranged in regular circles concentric with the axis of the structure. The beautiful, glistening whiteness of the object when the sun shines upon it makes it very conspicuous. The bubbles were slightly viscid, and in nearly every case there was a small fly pressed into the front end of the balloon, apparently as food for the Empis, as the attached species were partly Chironomus and partly Oscinids, and other Acalyptrate Muscids. In all cases they were dead.

The balloon appears to be made while the insect is flying in the air. Those flying highest had the smallest balloons. The bubbles are probably produced by some modification of the anal organs, as in Aphrophora and other leaf-hoppers, but no positive observations on this point could be made. It is possible that the captured fly serves as a nucleus to begin the balloon on. One case of a captured fly but no balloon was observed. After commencing, it is probable that the rest of the structure is made by revolving the completed part between the hind legs and adding more bubbles somewhat spirally. The posterior end of the balloon is left more or less open.

The balloons were so light and sticky that they could not be preserved with any success. The first lot obtained were placed 
in a corked vial, and had all collapsed by the next day. The second lot were placed in an open vial, which was left on the ground for a little while, and the ants carried off all the specimens. A third lot in open vials retained their shape in some

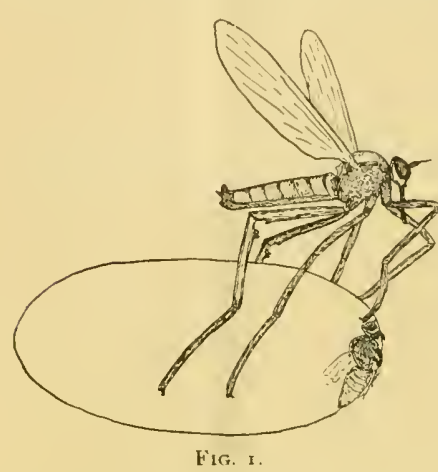
degree, but were all more or less shriveled. One placed in alcohol immediately dissolved.

The purpose of this structure is to attract the female. When numerous males were flying up and down the road, it happened several times that a female was seen to approach them from some chokecherry blossoms near by. The males immediately gathered in her path, and she with little hesitation selected for a mate the one with the largest balloon, taking a position upon his back. After copulation had begun, the pair would settle down towards the ground, select a quiet spot, and the female would alight by placing her front legs across a horizontal grass blade, her head resting against the blade so as to brace the body in position. Here she would continue to hold the male beneath her for a little time, until the process was finished. The male, meanwhile, would be rolling the balloon about in a variety of positions, jug-

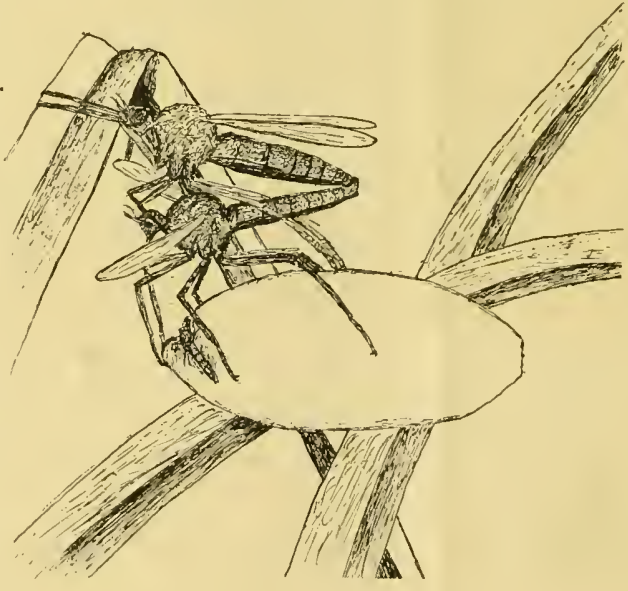

FIG. 2. gling with it, one might almost say. After the male and female parted company, the male immediately dropped the balloon upon the ground, and it was greedily seized by ants.

Of the accompanying sketches, Fig. I shows the position of 
the balloon when the male is flying. It is frequently carried farther back, apparently by the hind legs alone. Fig. 2 shows the position assumed in copulation, the male underneath rolling the balloon.

No illustration could properly show the beauty of the balloon, still less could anything worthy of the subject be made from the shriveled and flattened specimens that now remain in our

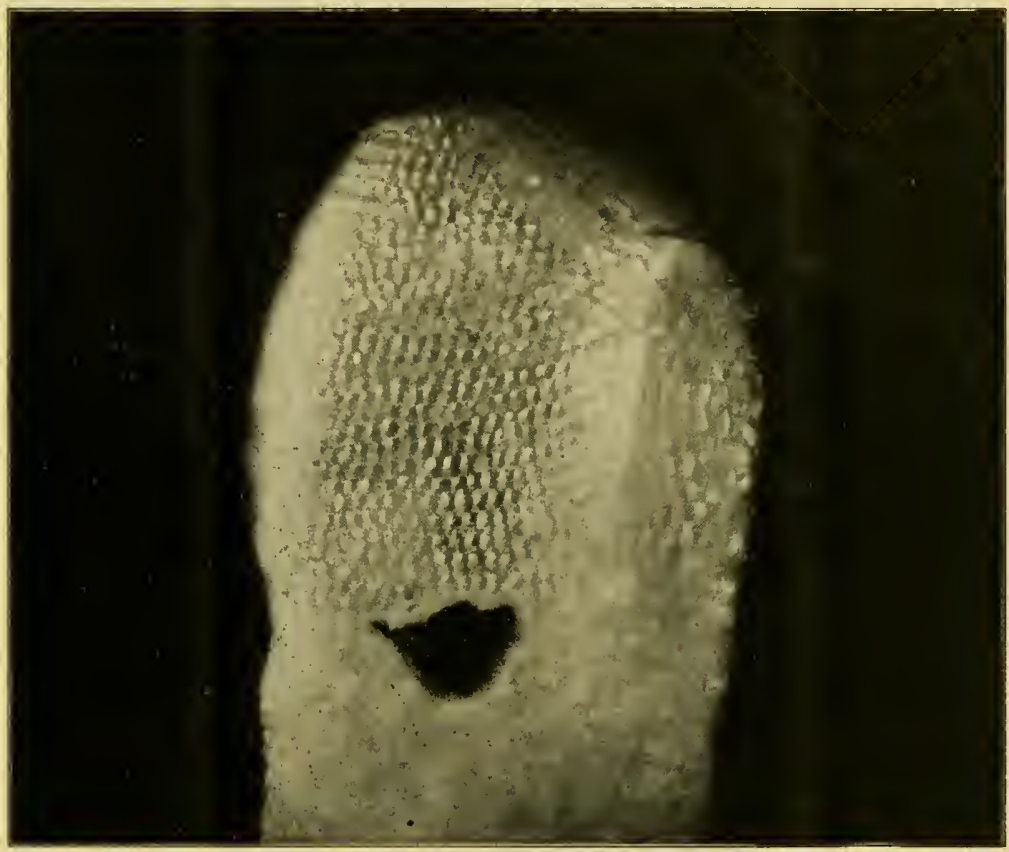

FIG 3.

possession. The half-tone (Fig. 3) serves only to show the way it is formed of bubbles.

The only published observations at all comparable with these are on the European species of Hilara, a genus of Empidx closely related to Empis, and especially on Hilara sartor Becker. Several entomologists have published articles on the species, and there has been considerable difference of opinion as to the nature and purpose of the structure carried by the fly, as well as the method of carrying it. Professor Mik, in the 
Wiener Entomologische Zeitung, Vol. XIII, pp. 27I-284, and Pl. II, Figs. 8-I3, gives an exhaustive discussion of the whole subject, with citations of the other authors and extracts from their papers. According to Mik, who had abundant opportunities for observation, the male produces a real web which is borne by the hind feet and serves to assist the fly in the somewhat peculiar gyrations of its flight. The different nature of the structure makes it unnecessary to go into further particulars here.

The species to which our observations pertain was sent to Professor Wheeler, of Chicago, who has been studying the family for several years, and identified by him as Empis poplitea Loew, "or a closely related species."

The use of the term "balloon" should not be taken to imply that the structure described is lighter than air. 




\title{
THE
}

\section{AMERICAN NATURALIST}

A MONTHLy JOURNAL IEVOTED TO THE NATURAL, SCIENCES IN TIIEIR

IVIUEST SENSE

\section{REPRINT}

FROM

\author{
Vol. XXXYI, Nu. 425. MAY, 1902
}

BOSTON

GINN \& COMPANY

The athenxum preøঞ

1902 



\section{NOTES AND LITERATURE.}

\section{ZOÖLOGY.}

Temperature of Insects. - Professor Bachmetjew's ${ }^{1}$ paper is one of those rare publications which is full of interest not only to the specialist in entomology but to biologists in general. The Russian author, with the equipment of the trained physicist, approaches a subject that has often been studied before, and after treating it in an exhaustive manner reaches new and important results, which would carry conviction in their very simplicity, even if they were not substantiated step by step by detailed tables of observations. The work of all previous investigators in determining the vital temperature of insects is briefly and critically reviewed as a preface to each of the main sections of the work.

In order to determine the temperatures, the insect was spitted through the thorax on a thermoelectric needle consisting of fused manganin and steel wires connected with a galvanometer. A cletailed account of the somewhat complicated apparatus and the method of using it are given in an appendix (pp. $3^{S-142) . ~ A ~ n u m b e r ~ o f ~}$ different insects, mostly larger moths, butterflies, and beetles, both pupal and imaginal, were used in the experiments.

The first part of the work is devoted to a consideration of the body temperature of insects. In his earlier experiments, Bachmetjew came to the conclusion that the temperature of the insect body varies within very considerable limits, apparently without any serious consequences to the life of the animal. He found, moreover, that in resting insects the temperature is the same or very nearly the same as that of the surrounding air. Subsequent experiments, however, led him to conclude that this is true only under ordinary conditions of moisture, temperature, etc., since these factors, when abnormal, have a very pronounced effect on the body temperature. Under normal conditions, when the temperature of the atmosphere is raised, the temperature of the insect, though rising, lags at first more and more behind

1 Bachmetjew, P. Temperaturverhältnisse bei Insekten. Experimentelle entomologische Studien vom physikalisch-chemischen Standpunkt aus. Bd. i, pp. 4I Go. Leipzig, Wilhelm Engelmann; I901. 
that of the atmosphere, and only begins to approach atmospheric temperature just before partial heat paralysis of the wing muscles sets in. After death the temperature of the insect and the air are the same. But when the air is very damp the body temperature of the insect is higher than that of the air. This is explained as due to evaporation of the body fluids and to respiration, the former having a tendency to diminish, the latter to raise, the temperature of the insect. Bachmetjew predicts that the study of the dependence of the body temperature on that of the air, under different conditions of moisture, will ultimately enable us to determine the metabolism of these animals, and hence their vitality at different temperatures.

The influence of the activity of the insect on its body temperature, long since noted by Newport ( $8_{37}$ ) and others, is exhaustively studied by Bachmetjew. While a moth is moving its wings its body temperature keeps rising, but falls suddenly with the cessation of this movement. The insect was studied under three conditions : first, at the ordinary temperature of the room ; second, at a higher temperature in the thermostat; third, at a lower temperature in a cold-air bath. Experiments conducted at room temperature show that the moth (Sphingid) is incapable of raising its own temperature higher than $38.5^{\circ} \mathrm{C}$. by means of muscular movement. Fluttering of the wings does not produce as high a temperature as "humming." At about $38^{\circ} \mathrm{C}$. the insect often suddenly changed from humming to fluttering, or rested completely. Bachmetjew interprets this change as due to partial heat paralysis of the muscles. It is a transitory phenomenon, which disappears with the sinking of the temperature during rest to that of the surrounding atmosphere. The temperature at which the wing muscles are paralyzed (in Deilephila euphorbice) increases with an increase of the temperature (at ordinary moisture) and reaches $45.5^{\circ} \mathrm{C}$, after which the moth loses the power of humming. Complete, i.e., no longer transitory, heat paralysis of these muscles supervenes at a body temperature of $49.7^{\circ} \mathrm{C}$. In somewhat moister air this result does not set in till $53^{\circ} \mathrm{C}$. is reached. In a single experiment on Deilephila at low atmospheric temperature the muscle paralysis also appeared, but at a lower temperature. At a body temperature of $-0.5^{\circ} \mathrm{C}$. all movements ceased, fluttering began at $2^{\circ} \mathrm{C}$, and humming not till $20^{\circ} \mathrm{C}$. had been reached. It would seem, therefore, that the temperature of partial paralysis of the wing muscles is directly proportional to the body temperature of the insect, as is also the case for higher temperatures. According to Bachmetjew, these effects of partial paralysis play a great rôle in the production 
of color aberrations in butterflies. He also suggests that further study of these effects may explain why so many moths are nocturnal, while the butterflies are diurnal. Some experiments on the influence of respiration showed that Deilephila at $29.4^{\circ} \mathrm{C}$. atmospheric temperature could raise its body temperature through at least $3^{\circ} \mathrm{C}$. by means of breathing alone.

The second and more important portion of Bachmetjew's paper deals with the vital extremes of temperature. It is divided into two sections, one dealing with the maximum, the other with the minimum temperature. The vital maximum is the highest temperature at which an insect is able to live. Experiments on Satumia fyri showed that the insect becomes very restless at a temperature of about $39^{\circ} \mathrm{C}$. and dies when the body reaches a temperature of $46^{\circ} \mathrm{C}$. This is also very near the lethal temperature for plants (Sachs and Schultze). This lethal temperature, however, depends on a number of factors. In general, it may be said that if the insect at high temperature first, has not been exhausted, i.c., has been artificially fed; second, is not desiccated, i.c., is in a sufficiently moist atmosphere; and third, presents the same conductivity to heat and the same body size for a given species, - its life will depend only on the coagulation or noncoagulation of its body fluids. Hence, the vital maximum is only another expression for the coagulation point of the body fluids. And if one knew the amount of water in the insect's albumins, especially of those albumins essential to life, the question of the vital maximum would resolve itself merely into a determination of the amount of water.

Bachmetjew's study of the vital minimum, i.e., the lowest temperature at which an insect can live, brought out some startling results. He found from experiments on a great number of insects that different species died at very different temperatures. But his most interesting results refer to the critical point, which is the temperature to which the fluids of the insect may be undercooled before they begin to congeal and then suddenly rise in temperature till the normal congealing point is reached. Bachmetjew points out the resemblance of this phenomenon to the well-known undercooling of water, which can be cooled to $-25^{\circ} \mathrm{C}$. without freezing, but at once rises to $0^{\circ} \mathrm{C}$. to freeze. Bachmetjew discovered the undercooling of the body fluids of insects by acciclent in an experiment on Saturnia pyrif. The insect was cooled to $-9 \cdot 4^{\circ} \mathrm{C}$., whereupon within a minute's time the temperature bounded up to $-\mathbf{I} .4^{\circ} \mathrm{C}$., the normal congealing point of the body fluids, and then remained constant for 
eleven minutes. In this case the critical point is $-9.4^{\circ} \mathrm{C}$. and $-\mathrm{I} .4^{\circ} \mathrm{C}$. is the normal congealing point. This insect revired within an hour after the experiment, and laid eggs on the following day. From this Bachmetjew concludes that the mere congealing of the body fluids is not lethal. In a second experiment a moth of the same species showed a critical point of - I $1.6^{\circ}$ C. (4.25 P.M.), whereupon the temperature rose at once to $-1.1^{\circ} \mathrm{C}$. The insect was kept in the cold, the temperature of its body again sinking to $-15.6^{\circ}$. At 6.15 P.M. it was removed to the temperature of the room, but could not be revived. It follows that the insect dies if its body is still further cooled after the rebound (the limits being not necessarily higher than $-2.5^{\circ} \mathrm{C}$. nor lower than $-15.6^{\circ} \mathrm{C}$.), or, as a general rule, it may be stated that the insect dies if its temperature be again reduced to about the point from which it rebounded. Further experimentation on this interesting subject led to the following general conclusions here briefly transcribed. The extreme degrees of undercooling of the fluids differ in different insects, and these extremes occur at nearly the same rate of cooling. The critical point, so far as its absolute minimum is concerned, is greater in pupæ than in imaginal moths and butterflies, whereas the maximum differs in pupæ and imagines. Owing to lack of material, the behavior of the larvæ could not be determined. With respect to sex, the degree of undercooling of the fluids in normal specimens is lower in the males than in the females. This is also the case after brief fasting; after protracted fasting, however, the degree of undercooling is lower in the males, but finally becomes the same in both sexes. On the other hand, the normal congealing point of the fluids is lower in the females than in the males. After fasting, it is the same in both sexes; but after protracted fasting, the relation is again reversed. Further investigation of this question showed that the insect juices have a lower critical point when the insect is fasting, but so far as its absolute magnitude is concerned, it diminishes on continued starvation. Repetition of undercooling gave the following results: On freezing a second time strong Lepidoptera exhibit a much greater degree of undercooling than on the first freezing; on being frozen a third time the fluids show almost no undercooling: This is also shown by weak Lepidoptera on the second cooling. Bachmetjew also studied the influence of the fluid coefficient on undercooling. If $M$ be taken as the total weight of the living insect, and $P$ its weight after drying on a water bath for a long time at a temperature of $115^{\circ} \mathrm{C}, M-P$ 
would represent the weight of the fluids which leave the body on evaporation at this temperature. The relation

$$
\frac{M-I}{M}=q
$$

is known as the fluid coefficient and signifies the percentage of fluids in a unit of weight of the living insect body. Experiment shows that the smaller the fluid coefficient the lower lies the normal congealing point of the fluids. The critical point is also influenced by the fluid coefficient, but this influence cannot be stated in general terms till the composition of the fluids has been further studied. Time also influences the critical point. If the temperature $(t)$ to which the insect is undercooled coincides at the same rate of cooling with the critical point $\left(K_{1}\right)$, the juices at once begin to congeal (i.e., time $=0$ ); but if $t$ does not coincide with $K_{1}^{*}$, the congealing of the fluids is delayed in proportion to this difference $\left(K_{1}-t\right)$.

Undoubtedly Bachmetjew's results are of a far-reaching character and will ultimately form the basis for important work along theoretical lines in physiology, and for practical applications of great moment (in economic entomology, e.g. !), for they throw light on the geographical and climatic distribution of organisms, the resistance of animals and plants to cold and heat, and the problems of anabiosis. That Bachmetjew himself is very sanguine concerning the results that may ultimately flow from his work is apparent when he says. "Es eröffnet sich somit ein ganz neues Gebiet für die Forscher, und wer weiss, ob die Zeit nicht nahe ist, wo man den märchenhaften hundertjährigen Schlaf auch bei Menschen künstlich hervorrufen könnte! Die Insekten wenigstens bieten die Möglichkeit dazu."

IV. M. W.

An Important Paper on Phoridæ. - Theodor Becker, of Liegnitz, Prussia, has recently published a work $^{1}$ of 100 pages, with five plates, on the family Phorida, which deserves notice among zoölogists in general because it is one of the finest pieces of systematic work that has been published on the Diptera.

The family Phorida includes only small species, generally from two to four millimeters in length, which do not offer to the observer with a hand lens a satisfactory series of specific characters. The genus Phora was early described and generally recognized from its

I Abhandlungen der k. k. zool.-botan. Gescllschaft in Wien, Bd. i, Heft I, I go I. 
peculiar venation; this led to the description of a large number of species by the earlier dipterists, among them Meigen, Macquart, Zetterstedt, Bohemann, Haliday, Rondani, and Egger, the types of which ultimately found lodgment in various public museums of Europe. Most, if not all, of these describers based their species chictly on size and color, having but little comprehension of the real specific distinctions. When they came to identifying each other's descriptions, confusion was worse confouncled, and down to the present time it has been impossible to get the family, which is mostly comprised in the single genus, into intelligible shape.

Mr. Becker secured for study the material contained in twelve public muscums of Europe, including all the types now in existence of the earlier descriptions, with a few exceptions. He not only made a thorough study of all these collections, but he has published a full report in this work on the named species and types in each, thus putting the old species in a perfectly clear light and preventing future disputes over alleged types and misnamed species in these collections.

In addition to this material and that in his own collection, Mr. Becker was able to study the collections of some eight dipterists of the present generation, so that his work may fairly be termed exhaustive.

Sixty-five European species of the genus Phora are described, of which twenty-two are new. The remainder of the family, as represented in Europe, consists of Trineura, three species; Conicera, two species; Gymnophora and Metopina, one each.

The arrangement of the paper is admirable, and includes the following sections: table of genera of the world; structure and characters of the genus l'hora; analytical table of species; description of species; enumeration of the named species in each of the type collections examined, with the proper status of each specimen; a brief division on biology; other European genera and species; extraEuropean genera, with their species; index of European species, including synonyms; list of accepted European specics; list of extra-European described species in the family, with references; explanation of plates, and table of contents. This will give an idea of the completeness of the work.

The characters used are largely those of the bristles, the "chætotaxy" of recent writers; without the use of these bristles it would be impossible to write an intelligible description of many of the species. There is no family of flies in which it is more essential. 
One might wish to see a more extended notice of the biology of the Phorida, but as long as we have not yet nearly reached the point where we can extend our classification to the larval stages, it is not improper to allow the natural history of the species to form a separate subject.

This paper will be of great advantage to American workers, as it will enable them to ascertain how far our species are identical with the European, Becker's descriptions being so exact that it will be possible to determine without comparison of specimens, I should judge.

To take up a family that is in a state of chaos and transform it into orcler and beauty by a single publication is a great achievement, and one not accomplished without long and arduous study. Mr. Becker has produced a monumental work, easily the greatest he has yet attempted, and one which may well be taken as a model by younger entomologists.

Habits of Insects. - An English rendering of the first volume of Fabre's delightful Sour'enirs entomologiques. Fitudes sur l'instinct et les maurs des insectes, though with an exceptionable title and an overburdened title-page, ${ }^{1}$ is to be heartily welcomed. It makes accessible to a larger circle some of the early work of a keen inquirer into the faculties of insects. Well and favorably known since 1879 , Fabre's observations have instigated similar and successful work elsewhere, and it is only from the philosophical sicle, Fabre being a rigid opponent to any form of evolution, that his writings are open to hostile criticism.

The volume under notice begins with an account of the habits and life history of Scarabeus saier, and is devoted almost wholly to the higher Hymenoptera, though incidental observations concerning other insects are given.

With due allowance for the many difficulties, the translation is fairly well done. Editorially the volume cannot be considered as altogether satisfactory; the supervision of an entomologist should have precluded the translation of srillon indifferently as "cicada," "cricket," or "grasshopper," the almost universal use of "feet"

1 Fabre, J. H. Insect Lifi. Sourenirs of a Nuturalist. Translated from the French by the author of Mademoiselle Mori. With a preface by David Sharp. Edited by F. Merrifield. With illustrations by M. Prendergast Parker. London, Macmillan \& Co.; New lork, The Macmillan Company, 1901. xii + 320 pp., 16 pls. 
(pattes) for "legs," and the frequent confusion between genus and family.

Footnotes recording similar work or opposite conclusions would have been valuable, and the lack of an index is especially regrettable.

S. H.

\section{BOTANY.}

The Rhodomelaceæ. - Originally planned as one of the series of monographs of the marine organisms of the bay of Naples, the author ${ }^{1}$ of this work has extended its scope until now it covers the entire family of the Rhodomelacex, as represented in all waters. Of its large quarto pages 109 are given to the general part, covering the anatomical development of the stem, the morphology of the vegetative organs, and the reproductive organs; $5^{8 S}$ pages are given to the special part, with detailed studies of all the species found in the Neapolitan region, and of all other species authentic specimens of which were accessible to the author; 248 species are elaborately treated in this part. The third part, "Systematic Results," 34 pages, includes notes on phylogeny, on the relation of the Rhodomelacex to other families, and a synoptical view, practically a key to the genera of the Rhodomelacex, giving under each genus the names, with descriptions, of the species described in the second part, and of such other species as the author had reason to consider sufficiently studied to leave no doubt of their position under his arrangement. The large genera Laurencia and Polysiphonia are excepted from this full treatment, only a portion of the species being mentioned, about which the many other species can be grouped; even with this reduction, 320 species are given in this third part.

A monograph of this character, from the hands of the one person competent for the task, is an important event, and the care and thoroughness with which it is done are remarkable. The author undertook the task in 1878 , and some of the plates were printed in 1885 ; after all, this long stretch of time seems none too much for the enormous amount of work involved. What the future may

${ }^{1}$ Falkenberg, R. Flora und Fauna dis Golfe's von Leafel. 26. Monographie. Die Rhodomelaceen. Herausgegeben von der Zoologischen Station zu Neapel. Berlin, 1901. xvi $+75+$ pp., $2+$ pls. 


\section{THE SYSTEMATIC POSITION OF THE DIPTERA.}

Havivg been a student of the Diptera for two years, I have come to the conclusion that the order is entitled to the distinction of being, as a whole, more highly specialized than any other. Entonologists who have attempted a general classification of insects have almost uniformly regarded the Hymenoptera as the higbest order, placing the Lepidoptera second, and the Diptera third. The only exception in America. I believe, is Professor Hyatt, who, in a recent book ("Insecta," by A]pheus Hyatt and J. N. Arms), has placed the Diptera at the head of the class, with the Hymenoptera second, and the Lepidoptera third. His argument for this arrangement is brief and forcible. The main features may be summarized as follows:-

The essential question which settles the rank of any insect is, How far does it deviate in structure, and through what line of descent has it developed, from its Thysanuriform ancestors? To introduce the subject of instinct or of usefu]ness to man is to confuse our ideas, for we cannot translate the data furnished by such a criterion in to terms of the other standard. Applying this principle, he takes the following features of Diptera to show that they possess a degree of specialization surpassing any other order:-

1. Larval structure: "The young of even the generalized forms of Diptera are, as a whole, farther removed from the Thysanuriform type than those of any other group. The secondary larval form, which in the case of the Diptera is always footless and often an almost headless maggot, has complete possession of the younger stages. As Friedrich Brauer has pointed out, the general absence in the larva of Diptera of the thoracic legs, even although living in situations that seem to demand their development, shows that they must have inherited this peculiarity from an ancestral form whose larva had lost them. This comparative inflexibility of the larval stage is sufficient of itself to show that there is now a wide gap between the existing Diptera and all other orders of insects, and that this chasm is not closed by the resemblances of the parts in the adult to those of the Lepidoptera or isolated forms in other orders" (pp. 2ז3, 2it).

2. The presence of but two wings: "The tendency to the enlargement of one pair of wings, like the tendency to the enlargement of certain pairs of thoracic legs and the reduction of other pairs, or a change in their structure and function, so that the insect makes a departure from the conrentional normal type of four equal membranous wings and six equal-jointed legs, is everywhere an index of specialization " (p. 2it). 
3. The mouth parts are developed for sucking ouly.

4. The attachment of the abdomen to the thorax in some flies shows that they once possessed a pedunculated abdomen, similar to that of Hymenoptera (p. 251).

Of these features, the first is the most weighty. Had not its importance been overlooked, the order could never have been thought inferior to the Lepidoptera, of which the members have while larve thoracic legs and usually abdominal ones also. Among the Hymenoptera, the Tenthredinidr have thoracic legs and even more numerous abdomiual ones than the Lepidoptera. The Uroceridæe also have rudimentary thoracic legs, although the larvæ are borers in wood.

The second and third arguments are essentially one in principle. In the lower winged insects, we find both pairs of wings of equal size and importance. The Hymenoptera show a condition in which the hind wings are much smaller aud so of less use. Now, why do not the Diptera represent the extreme of this series? The question is not whether two pairs of wings or one pair are in themselves "bigher;" it is rather, Which type shows the greater departure from the forms universally acknowledged as ancestral ? So regarding the mouth development: If the mandibular mouth of Thysanura, Odonata, etc., be admitted as representing the ancestral form, then surely the mouth combining mandibular and suctorial apparatus is intermediate, and that with only suctorial organs is the ultimate degree of specialization. The recent researches of Dr. John B. Smith (Trans. Am. Ent. Soc., XVII.) show that true mandibles are almost never present in Diptera (be found them ouly in Simulium). Although his conclusions in this respect, as well as in regard to the homologies of the dipterous mouth in general, are widely different from those of earlier investigators, they are probably correct. In summing up, he says (p. 339), "The development required is simply a further development of the line started in the Hymenoptera."

An argument that strongly reinforces the first one above is found in the fact that the embryo in Diptera, at least in the higher forms, does not develop any traces of legs, differing in this respect from eveu the highest $\mathrm{Hymenoptera,} \mathrm{which}$ first develop the legs and then reabsorb them before hatching (Psyche, June, 1891, p. 98).

The subject of mimicry also throws some light on these relations. As is well known, the Diptera afford many interesting cases of mimicry, and it is important to our theory to notice that they generally imitate the Hymenoptera, especially the very highest forms, such as wasps, humble-bees, and even honey-bees. One of the most widespread of all species, Eristalis tenax Linu., is such a good imitation of 
the honey-bee as to deceive the very elect. One of my students, an enthusiastic collector and well acquainted with this case of mimicry, once grasped a bee in his hand, under the impression that he was capturing one of these flies. Now, on any theory, we must admit that these species of flies are of more recent origin than the species which they mimic. Most of these imitative flies belong to the family Syrphidæ, which is considered to be one of the oldest of the group Cyclorrhapha, comprising the higher flies.

The Diptera, as a whole, are wonderfully rich in peculiar modifications of structure. In almost any organ the variety of forms exceeds that of any other order. Even the antenna of beetles do not surpass, if they equal, those of flies in this respect. The wings are far more variable in venation than those of any other order. The variety and complexity of organs for grasping the female are almost beyond belief to one who has not seen them.

The one thing which has prevented the recognition of the real rank of the Diptera is a lingering notion that specialization by reduction really brings an insect down to a lower position in the scale. The word "high" suggests the idea of "complete," or "perfect," or "typical." If Professor Hyatt's test were to exclude every other, as it ought to, there could scarcely be any further disagreement on the question of the highest order.

The line of argument here suggested points to the Pupipara as the highest of all insects; nor would $I$ in the least seek to evade the conclusion. Of the group. I have seen only the Hippoboscidæ; among these the sheep tick, Melophagus ovinus Linn, appears to deserve the highest rank.

J. M. ALDRICH. 



\section{A Collection of Diptera from Indiana Caves.}

By J. M. ALDRICH. 



\title{
A Collection of Diptera from Indiana Caves.
}

\author{
BY J. M. ALDRICH.
}

This collection embraces 12 species, of which five are herein described as new, one constituting a new genus Two species are only generically determined. The family Mycetophilida is represented by five species, Helomyzidæ by four, and Psychodidæ, Borboridæ and Phoridæ by one each. The Helomyzidie furuish by far the greater number of individuals It does not appear that any of these species are wholly confined to a cave life. They show no marked peculiarities of structure and are probably found in shady places generally. None of those previously described, except Blepharoptera defessa, have been heretofore known to inhabit caves.

\section{Macrocera hirsuta Loew.}

Loew, Centuries IX, 5.

One specimen, Truett's Cave, July 9. Slightly larger than Loew's type, thoracic dorsum and pleuræe more infuscated; halteres brownish at tip. Described from the District of Columbia. I have no knowledge of any captures of the species since that time till now.

The specimen noted was taken on the wing in the main room of the cave, 800 feet from the entrance.-W. S. B.

\section{Sciara SPP.}

Two species, both small. Of the first, which is dark with a shining black thoracic dorsum, there are seven specimens, six from near the mouth of Salt Petre Cave, the other from Wyandotte Cave. November 5,1896 . Of the second, which is lighter with yellowish brown thorax, one specimen is from Donnehue's Cave, July 14; another, Wyandotte Cave, near Augur Hole.

The specimens of Sciara were in all instances taken in small crannies in damp portions of the care. The "Augur Hole" of Wyandotte is about threefourths of a mile from the entrance. Species of the genus are quite common in Mammoth Cave, Kentucky, and the young, according to Osten Sacken, live on decaying vegeiable watter, fungi, etc.-W. S. B.

\section{Mycetophila unbraticus $\mathrm{n}$. $\mathrm{sp}$.}

Female. Front dark brown; palpi and three basil joints of antennae yellow. Thorax clay yellow, somewhat pruinose with white, the dorsum somewhat infuscated and provided with numerous stout black hairs along the sides; scutellum and metanotum also brownish, the former with two 
distinct hairs. Abdomen brown, compressed, the distal part of each segment with a lighter ring, which is broader underneath. Legs pale yellow with a distinct fuscous tinge. Coxx paler, the front ones with only a few fine hairs at tip; tibin wholly witbout spines except at tip, still on the posterior ones a few scarcely perceptible setulæ. Tarsi elongated, uniformly infuscated, slightly darker than the tibix; in the front leg the eutire tarsus is about four times the length of the tibia, in the middle leg two and a half, and in the hind leg one and a half times. The tibial spurs on the front leg are a fifth the length of the metatarsus; on the other legs a third.

Wings without maculx, tinged with yellow along the costa and to a less degree all over the apical half. Venation as figurerl.

Length, $5.2 \mathrm{~mm}$.; of wing, $4.5 \mathrm{~mm}$.

One female, Shiloh Cave, July 15.

The specimen was taken from beneath a rock about $\$ 00$ feet from the entrance. A member of the genus has been recorded by Osten Sacken from Bradford Cave, 16 miles

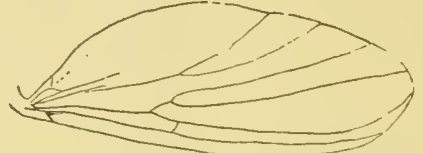

Wing of Mucet phila umbratieus n. sp. from New Albany, Ind. The larve live in fungi.-W. S. B.

\section{ODONTOPODA, new genus.}

(boúre tootli; ;oús foot.)

(Mycetophilida near Glaphyroptera.)

Ocelli three, all large, nearly in a straight line; antennæ 16 . jointed, the two basal joints distinct, the others cylindrical, the third longest; palpi four-jointed, first short, second a little longer, third longer than the two preceding, fourth a trifle shorter; coxæ elongated; abdomen (male) long, slender, clavate, composed of seven distinct segments besides the hypopygium. Wings, fourth longitudinal arising near the base; third vein not brauched; costal vein not extending beyond tip of third longitudinal; fifth vein forked; auxiliary vein ending in the costa almost half way to the apix; small crossvein nearly equal in length with the first segment of the third vein; fourth vein with a very thin anterior branch arising at the origin of the crossvein, or seemingly from the crossvein itself.

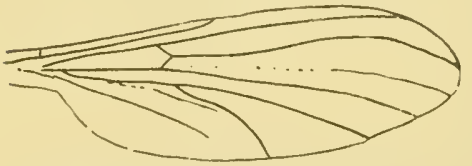

Wing of Uuveropudu sety $i$ n. sp.

\section{Odontopoda sayr, n. sp.}

Male. Front black, antenne brown, except the first three joints, which are yellow; mouth parts yellow; thorax and coxie yellow, rather pale; the dorsum, however, more acorn-colored without distinct lines. Abdomen brown, the bases of the segments and a larger part underneath of 
a lighter color; seventh segment distinct, nearly as long as the sixth, hypopygium as long as the seventh, first segment over half as long as the second. Femora and tibia yellow, with a brownish tinge; front tarsi black (the others wanting, but doubtless black). Wings of a clear yellow tinge, lighter posteriorly; third vein with a rather strong curvature.

Length, $6 \mathrm{~mm}$.; of wing, $4.7 \mathrm{~mm}$.

One male, Marengo Cave.

The single specimen was on the side of a damp rock, 400 feet from the entrance.-W. S. B.

5. Psychoda minuta Banks.

Banks, Canad. Eut., XXVI, 331.

One specimen, Salt Peter Cave, Crawford County.

6. Ulomorpha PIlosella Osten Sacken.

Osten Sacken, Proc. Acad. Nat. Ści. Philadelphia, 1859, 342

Osten Sacken, Monograph N. A. Dipt., IV, 233.

One specimen, Porter Cave.

7. Blepharoptera defessa Osten Sacken.

Osten Sacken, Bulletin U. S. Geol. and Geog. Survey, Vol. III. No. 1, p. 168 , note.

One female, Wyandotte Cave.

By the kindness of Professor Packard, I was enabled to see the description of this species. The following sentence is at the end of the description: "Blepharopterce are often found in caves, where they are said to breed in the excrement of bats." The description occurs as a footnote to an article by Professor Packard on "A New Cave Fauna in Utah," but the specimens described were from Hundred Dome Cave, near Glasgow, Kentucky, and were also reported from Wyandotte Cave, amoug others.

This is the Anthomyia of Cope's "Fanna of Wyandotte Cave." Ind. Geol. Surv., 1872, 160. For description and figure see also, Packard's "Cave Fauna of North America," 1889, 80.-W. S. B.

8. Blepharoptera pubescens Loew.

Loew, Centuries II, 82.

Seven specimens, both sexes: Shiloh Cave, July 15 (1); Salt

Peter Cave (2), Coon's Cave (2), Porter Cave (1), IVyandotte Cave (1).

The species was described from Massachusetts.

9. Blepharoptera latens $n$. sp.

Brownish-black, head, knees, venter and tip of abdomen reddish; two vibrissa each side. 
Head dark red, rather variable in color, vertical triangle black, second fronto-orbital bristle a trifle smaller than the preceding; antennse dark red, third joint more or less infuscated; face and mouth parts dark red; two large vibrisse on each side, one a little longer than the other, a narrow strip only is bare below the eye, the remainder of the cheek with rather coarse black pubescence; occiput black above. Thorax black, the roots of wings, halteres and pleural sutures red or yellowish.red; scutellum and mesopleuræ bare, hypopleuræ with a group of four ascending bristles near the upper edge, otherwise bare on the sides except for a little very small scatteriug black pubescence; underneath, between the fore and middle coxæ, are very numerous bristles. Abdomen black, its tip, the venter, aud usually the posterior margin of each segment red. Coxæ and femora black, hairy, the latter stout; trochanters and knees red; tibiæ usually with a considerable red or reddish yellow, especially near the middle; tarsi almost uniformly brown. No special long bristles on the legs. Wings without spots, slightly yellow, the costal bristles small.

Length, 5 to $5.5 \mathrm{~mm}$.; of wing, 4.5 to $5 \mathrm{~mm}$.

Nine specimens, both sexes: Donnehue's Cave, July 14 (3); Shiloh Cave, July 15 (1); Porter Cave, (2); Mayfield's Cave, July 9 (3). Two of the specimens have numerous mites attached to the body.

\section{Blepharoptera siecus $n$. sp.}

Cinereous, largely yellow, scutellum pubescent.

Head yellowish, vertical triangle and upper part of occiput black, second fronto-orbital bristle smaller than first. Antennæ far apart, yellow, third joint somewhat darker, one vibrissa, the small hairs behind it confined to a narrow strip close to the oral cavity. Dorsum of thorax brown, about the edges more yellow; humeri, the posterior part and the scutellum usually entirely yellow, scutellum with distinct black pubescence besides the usual bristles. Pleure yellow with a darker color on the meso and hypopleure, the former part bare, the latter with one ascending bristle above and almost imperceptible sparse black pubescence, underneath a few bristles; tegulæ and halteres yellow. Abdomen on the basal half quite blackish, overlaid with cinereous dust, toward the tip yellow; male hypopygium large. Legs principally yellow, but varying in different individuals. In both sexes a row of six or eight bristles in fiont near the tip of the middle femur; in male a similarly placed row, but higher up, on the hind femur, numbering four or five. Wings slightly yellow, the costal bristles large.

Length, 3.5 to $5 \mathrm{~mm}$; of wing, the same.

Eighteen specimens, both sexes: Eller's Cave (3); Porter Cave (11); Mayfield's Cave, July 9 (2); Donnehue's Cave, July 14 (1); Wyandotte Cave (1).

The species of Blepharoptere were the largest and most common Diptera noted in the caves. They were found in the damper portions of nearly every care vis- 
ited, on the walls and roof. They were never noted on the wing, except when disturbed, when they would fly but a short distance before alighting. The large species were about as long as, but more slender than, the common house fly. The larvæ, according to Osten Sacken, live in fungi and the excrement of bats. -W. S. B.

\section{Limosina tenebrarum $\mathrm{n}$. sp.}

General color throughout, dark brown, sub-shining. Front, face, edge of clypeus and proboscis the same, the last at the tip yellowish; third joint of antenna rounded, arista slender, microscopically pubescent. Dorsum of thorax with moderate bristles; scutellum concolorous, with four bristles; pleuræ with a little yellow along the sutures; halteres yellow. Legs of simple structure; the tibix a trifle lighter than the femora, their tips and the tarsi yellow; hind metatarsus but little thickened, two. thirds of the length of the following joint. Wings as figured. The last section of the third vein perfectly straight, the fourth beyond the posterior crossvein becoming extremely thin, yet traceable to the margin; second and third sections of costal vein sub- Wing of Limosinatenebrarum n.sp. equal. The wings are moderately tinged with brown.

Length 2 to $2.1 \mathrm{~mm}$; of wing, 1 to $1.3 \mathrm{~mm}$.

Ten specimens, both sexes; Truett's Cave, July 9 (2); Donnehue's Cave, July 14 (2); Clifty Cave (1); Marengo Cave (1); Wyandotte Cave (3); same, near Augur Hole (1); same, November 6, 1896 (1).

The venation will readily distinguish the species.

The specimens from Donnehue's and Clifty caves were taken from piles of half dry excrement of the raccoon. Those from Wyandotte from beneath stones in the vicinity of remains of dead bats near the "Scuttle." The insects leap a few inches, rather than $\mathrm{Hly}$, when disturbed.-W. S. B.

12. Phora nigriceps Loew.

Loew, Centuries, VI, 99.

Nine specimens, Wyandotte Cave, near Augur Hole.

Taken from the mouldy remains of bread, chickens, etc., near the "Augur Hole," three-fourths of a mile from the mouth, July 27 , 1896.-IV. S. B. 



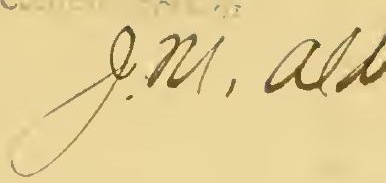




\title{
A NEW GENUS AND SPECIES OF TABANIDAE.
}

\author{
BY J. M. ALDRICI, BROOKINGS, SOUTH DAKOTA.
}

The general appearance of the fly is that of a particularly fine large silvery Hippoboscid, with brown wings. Nevertheless, an examination shows it to be truly Tabanid in every respect; in fact, I was at some loss for a while to fix upon a set of generic characters which would clearly separate it from all the present genera of Tabanidae. The venation is normal; the antennae resemble Pangonia in shape and number of annulations; the face is that of Chrysops. The upper corner of the eye, making an angle of about 70 degrees, and not in the least rounded off at the tip, but rather produced a little in a very fine point, beyond which is an impressed line, running to the occiput, is one of the best characters. The general proportions of the body, also, are different from those of any other members of the family known to me.
Its habits are unknown, but from its appearance the conclusion looks probable that it lives like a Hippoboscid upon some bird or mammal. Still, there are no modifications of structure that give strong support to this theory. Its claws are distinctly larger than those of Tabani of its size, and the large pits at the bases of the hairs on the first and second antennal joints seem to indicate an unusual development of the sense of touch in this region; both of which peculiarities are not without weight.

Goniops n. gen.

Spurs present on hind tibiae, absent from front ones. Eyes narrow, terminating above in an acute angle. Ocelli present. Front broad in female, the callosity longitudinal. Proboscis in repose directed forward. Thorax strongly arched, subglobular. Abdomen (from tip of scutellum) not longer than, and head but about half as wide as, the thorax. 
G. hippoboscoides, n. sp. ㅇ. Head almost uniform light yellow, between the ocelli tinged with brown. Eyes black, bare, not approximated to each other. Front broad, -wider anteriorly, with yellow pollen on the sides, a longitudinal callosity more whitish, extending from the ocelli to the beginning of the antennal prominence; in dried specimens a variable impressed line on each side of this callosity. Antennae situated on a distinct transverse prominence, yellow, the third joint more reddish; second joint almost annular, third tapering quite symmetrically, composed of eight annuli. Face yellow, strongly protuberant, shining. Proboscis reddish, directed forward, reaching but little beyond the antennae. Palpi slender, long, yellow, with yellow pollen and abuudant blackish hairs. Posterior orbits wide, conspicuous, with yellow pollen.

Thorax whitish yellow below, more brownish above, with minute, appressed, silvery yellow pile; on the anterior border just a trace of a slender, median, reddish line; on each side a broad, indistinct reddish stripe, interrupted along the transverse suture. Scutellum short, as wide as the head, yellow.

Abdomen short, broad, covered with ap. pressed shining silvery-yellow pile; seven visible segments, the last narrow, but little protruded, showing a distinct emargination.

Legs uniformly light yellow, the claws black except at base. Spurs of moderate size on middle and hind tibiae.

Wings hyaline, with a deep brown cloud extending across them, including the following parts: the stigma, all of the marginal cell except the proximal end, all of first submarginal, all of the second except tip, all of the first posterior except posterior half o the distal end, the proximal half of the discal, all of second basal, and middle of anal. There is a characteristic small clear spot in the second basal, at the anterior distal angle. The cloud is clearly defined behind, but fades more gradually in front. The branch of the third longitudinal vein shows a tendency to emit a stump of a vein. In one of my specimens the veinseparating the third and fourth posterior cells is obsolete for the greater part of its course.

Length 12 to $13 \mathrm{~mm}$. Width across expanded wings, $28 \mathrm{~mm}$.

Described from two female specimens, received from Mr. Henry G. Klages, Jeannette, Northumberland Co., Penn.

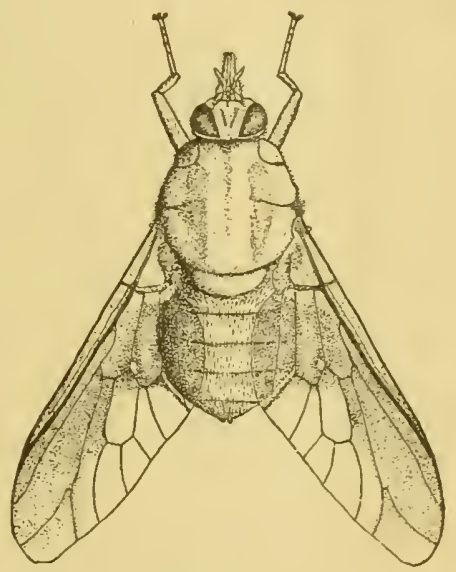

Fig. 1 .

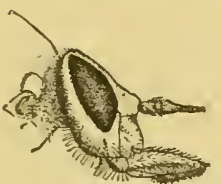

FIG. 2.

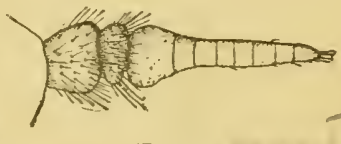

Fig. 3 .
Fig. I shows the insect from above, the wings being diagrammatic. Fig. 2 is a side view of the head. Fig. 3 an antenna. 



\section{Goniops and other Synonyms.}

By J. M. AIDRICH.

I an greatly obliged to Mr. James S. Hine for pointing ont the identity of my Goniops hippoboscoides witl Pangonia chry'socoma O. S. I see on comparison that there is no doubt of the synonymy. Osten Sacken refers to the species as being rather different from the rest of those included in Pangonia, and I consider the genus Goniops a good one. The species will therefore be known as Goniops chrysocoma O. S.

I must confess to a feeling of sadness that this first-born of my entomological activity slould be so early cut down. I have frequently consoled myself, when other work proved unsatisfactory, by reflecting on the brilliant discovery that I brought forward in that first paper!

In the few papers that I have published on the Dolichopodidæ, I have made several synonyms that I subsequently discorered for myself ; these I believe should be recorded for the benefit of other workers in Diptera.

I. Aptorthus Aldrich, Kans. Univ. Quart., ii, 48, 1893.

This I recently found is identical with Mesorhaga Schiner, Novara, 217, I868, described from Sonth America. The species I described are all valid.

2. Dactylomyia Aldrich, 1. c., 15 I.

The type, gracilipes, had been previously described by Loew as Saucropus superbicns. Later writers have rejected the genus Saucropus, placing the species under Neurigona. Since I have become acquainted with several of the long-legged species of this genus, I do not think that there is any justification for Dactjlomyia.

The synonymy in this case was made out independently by Professor Wheeler, and has been referred to by him in his recent extensive paper on the Dolichopodidæ (Proc. Cal. Acad. Sci., 1899).

3. Metapelastoneurus Aldrich, 1. c., I52.

This genus was based on the peculiar development of the hypopygium in a species of Pelastoneurus. Since the time of establishing it, I have often doubted the adrisability of using 
such characters, unless of very remarkable form, and accompanied with some other tangible marks of distinction. Recently I have been engaged in working up the Dolichopodidæ for the Biologia, and I find so many forms of hypopygium in the genns Pelastoneums as to leave no doubt of the untenability of n1y genus. I discard the name the more willingly, from the fact that it is the most villainously compounded (with three or four exceptions) that I ever inflicted on a long-suffering public.

4. Xanthotricha Aldrich, Trans. Ent. Soc., London, I896, 339.

This is identical with Thrypticns Gerstaecker, Stett. Ent. Zeit., I 866, 43. It has also been described by Wheeler under the name of Aphantotimus, which would have been prior to my name. Wheeler has referred with a doubt to this synonymy in his paper, p. 3o. By the way, I may take occasion to remark that my Th, minor differs from his aillistoni in having antennæ which are yellow, except the tip of third joint.

The flat or concave space before the scutellum cannot be a character of importance in this genus, as it does not occur in most of my specimens. As the species are minute and very soft, shriveling or drying, it is usually impossibie to speak with certainty on this point. When I described the genus, there seemed to be a difference from Aphantotimus in this part of the structure; but I am now convinced that it is evanescent.

5. Chrysotus apicalis Aldrich, loc. cit.. 330.

This species has had such a checkered history that I can best express it by putting it in the form it might assume in a catalogue as follows:

\section{Chrysotus barbatus}

Loew, Neue Beitr., viii, 48 ; Mon. N. A. Dipt., ii, 39 (both male only, as Synarthrus barbatus) ; Neue Beitr., viii, 63; Mon. N.

A. Dipt., ii, 75 (hoth female, as Chrysotus validus).

Wheeler, Ent. News, vii, I54 (Xiphandrium americanum).

Aldrich, Trans. Ent. Soc. Lond., I896, 330 (Chrysotus apicalis).

The synonymy of Xiphandrium is on Wheeler's authority.

6. Diaphorus approximatus Aldrich, Trans. Ent. Soc. Lond., I896, 321.

This is the same as our old friend D. spectabilis Loew.

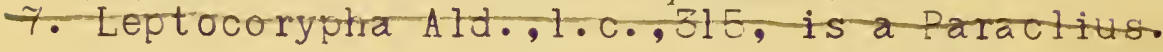




\title{
Flies of the Leptid genus Atherix used as Food by California Indians (Dipt.).*
}

\author{
By J. M. Aldrich, Moscow, Idaho.
}

In March, I9II, as I was making plans to investigate the Ephydras and other insects of western salt and alkaline lakes, I wrote to the Commissioner of Indian Affairs in Washington, mentioning the well-known use of an Ephydra at Mono Lake as food by Indians, and asking if any information could be procured for me in regard to other places in the West where such food was used. The Commissioner obligingly sent a circular to employees of the service in the West, which elicited several responses, one of which brought the first intimation of the use of a Leptid fly as human food.

Mr. Joseph A. Garber, farmer in charge of the Yainax subagency, Yainax, Oregon, wrote down two statements made to him by Indians living at or near the stub-agency, which I am permitted to publish. The Indian name under which it is reported that the Ephydra was used was "Koo-chah-bie," and this was used in the circular of inquiry.

"Statement of Chief Ben Lawver:

"Ben Lawver, an old Modoc Indian now living at Yainax sub-agency says that this fly which was used for food by the Indians was called by the Modocs and Pitt Rivers Ha-libwah, but after the flies were prepared for use as food, the product was called Koo-chah-bie. There are a few of these flies on Sprague River in this county and they are still called the Ha-lib-wah fly by the Klamath Indians.

* This paper is one of the results of an investigation carried on with the aid of an appropriation from the Elizabeth Thompson Science Fund. 
"About forty years ago when the Indians used the Koo-chahbie as food, they would go to Pitt River in Modoc County, California, at a point about ten miles down the river from where the little village or town of Canby now is. The time for gathering the flies was some time in the early summer. The Indians would place logs across the river in about the same manner that a present-day log or lumber boom is constructed. Then they would go up stream and shake the flies off the willow bushes growing along the banks of the river. The flies falling on the water would float down stream and lodge against the logs in great quantities. As many as a hundred bushels could be gathered in this way in a single day. The Indians used a kind of basket to dip the flies from the water and carry them to the place where they were to be prepared for food.

"A pit was dug in the ground about $\mathrm{I} / 2$ to 2 feet deep and about 2 feet or more square. Then two layers of stones were placed in the bottom of the pit, each layer being about three inches thick. A wood fire was built on these stones and more stones were put around and over the fire. When the fire was burnt out and the stones were hot, all the stones were removed except the bottom layer. Then green tules or green coarse grass was spread out on the bottom layer of rocks. The walls of the pit were lined with hot rocks also, and this inclosure lined with tules or grass. The oven-like inclosure was then filled with the flies. These were covered with green coarse grass and the whole covered with more hot stones. Water was then poured on the hot stones of the walls of the pit. the hot stones converting it into steam.

"As soon as the water was poured on, dirt was hurriedly thrown over all to the depth of several inches. The flies were allowed to cook in this manner until the heat was pretty well expended. The dirt and grass were then removed from the top and the mass allowed to cool. When sufficiently cooled the product was taken from the oven and was ready for use as food. In this state it was called by the Modoc and Pitt River Indians 'Koo-chah-bie.' When cold Koo-chah-bie is about the consistency of head-cheese, having a reddish brown color and can be cut into slices with a knife." 
"Statement of William Turner Jackson:

"William Turner Jackson, a Pitt River Indian now living near Yainax, Oregon, says that he saw this fly forty or more years ago, when he was a mere boy, in great quantities on a mountain side about eight or ten miles northeast from the postoffice or village of Lookout, in Modoc County, California. It seems that these flies, according to his statements, would gather at or near the head of a small canyon through which flowed a small stream of water. He never saw them at any other place in quantities and if one would go a quarter of a mile from this point in any direction there would be practically no flies. These flies gathered there some time in the month of May, and could be gathered by the tons. The trees, bushes and rocks were covered with them in places to the depth of five or six inches. Hence it was no trouble to gather them, for they could be scraped off the rocks and trees into great heaps. They would alight on the Indians until they were literally covered with them.

"The time of gathering them was in the cool of the morning when they were all settled and too cold to fly. In the heat of the day the air would be so filled with them as to exclude the sun and one could see but a short distance. (Where the flies came from and where they went to from this place is not known by the Indians who gave me this version of the incident.-J. A. G.)

"Indian Jackson also says that the flies were gathered in great quantities and prepared for food.

"A large pit was dug in the ground and the same materials lised in constructing the oven as those mentioned in the Ben Lawver statement. But before the flies were put into the oven they were dumped into large baskets and mashed up and kneaded like a housewife works her paste when preparing to bake bread. The mass is made into loaves like bread and placed in the oven side by side. There may be a half dozen or more layers of these loaves in one oven witl the hot stones between the layers. A great quantity could be cooked or baked in one oven in this manner. When this product was baked and dried it could be sliced from the loaf and used as food. 
"The food was called at that time and place by the Pitt Rivers 'Why-hauts.' When the Indians had gotten as much of the Why-hauts as they needed for winter supply, they carried it away to their places of living. A great deal of this was used as winter food."

The two places described by the Indians are both on Pitt River in the southern part of Modoc County, the northeastern county of California, and are not much more than ten miles apart by the data given. The two Indians it will be noticed belonged to different tribes, which probably accounts for slight differences in handling the flies. I believe both accotnts are truthful, although the quantity of material secured may be a little exaggerated.

The identification of the fly as a nember of the genus Atheri. is very easy. About the year I900 I was at Logan, Utah, early in July, and joined a fishing party which drove to a point southeast of Avon, in the south end of Cache Valley, on a small stream in the mountains. I distinctly remember seeing masses of flies of the genus Atherix come floating down the stream, and in one spot where a stick lay partly under water they would lodge so that a handful could easily be picked up. At the time I had no place to put the insects for preservation, and did not collect any, but I recognized the genus. In the summer of I 898 also, at Hailey, Idaho, or a few miles above the town, I noticed on the underside of a wagon bridge crossing Wood River masses of old dead flies that had apparently been attached to the timbers of the bridge for several years; they were hanging over the water. Material which I collected here was afterwards destroyed by a fire in the University of Idaho, and again I am not sure of the species, but I collected Atherix variegata at Hailey on another occasion. It would be necessary to collect in the Pitt River region to feel certain of the species of the above account by the Indians.

The explanation of the gregarious habit of the fly is that the females deposit their eggs collectively in this manner. The female does not fly away from the egg mass, and other females gathering on the outside of the cluster and also depositing their eggs results in the formation of a mass of eggs and 
flies several inches deep. An instance of this is cited by Ives, in Entomological Nerus, i. 39, I890, and Dr. Riley, commenting on the case in Insect Life, ii, 386, I890, mentions something similar, but possibly not the same. The Ives material came from Pemberton, New Jersey.

This habit in Atherix is much better known in the European Atherix ibis, in which it has often been described. Verrall (British Flies, v, 288, 1909), quotes a condensed description of the habits of the species from Walker (Ins. Brit. Dipt., i, 70) - "The female of this fly is gregarious, and attaches its eggs in large clusters to boughs hanging over streams, and there remains, and shortly dies. The cluster is generally pearshaped, and sometimes contains many thousands of dead flies, and continually receives accessions by new comers settling upon it. When the larva is hatched it falls into the water, its future residence; it has a forked tail about one-third the length of the body, and has the power of raising itself in the water by an incessant undulating motion in a vertical plane." Williston, in the 3 d edition of his Manual of North American Diptera, p. 160 , also refers to this habit. 



THE GEOMETRIIA IN "THE MOTH BOOK." BY REV. G. W. TAYLOR, WELLINGTON, B. C.

It seems a little ungracious to call attention to errors in so excellent a work as "The Moth Book," and presumptuous for a novice to criticise so eminent an authority as its author, but perhaps it is as well for the sake of the many amateur collectors who will name their captures from Dr. Holland's beautiful plates that the few mistakes that seem to have crept in should be pointed out.

There are four plates upon which species of Geometridæe are figured, and I think that in a few cases the names attached to the figures ought to be changed.

On Plate XLII., figure 25 represents Alsophila pometaria, not Paleacrita vernata. Figure 32 on the same plate is Macaria infimata, as pointed out by Dr. Dyar in the January number of this journal. I have on several occasions received specimens of $M$. infimata from eastern collectors as Eupithecia absynthiata. Figure 49 is Petrophora fluctuata not Mesoleuca intermediata.

On Plate XLIII., figures $\mathrm{I} O$ and II represent Hydriomena excurvata $=$ Ceratodalia Gueneata, Fackard, not Hydriomena custodiata, which is the Ochyria Gueneata, Packard. Figure 36 seems to be Deilinia erythremaria rather than $D$. variolaria, and figure 39 represents the European form Philobia notata, and not the western American P. enotata.

On Plate XLIV., figure 2 is an excellent portrait of the Caripeta seductaria of Strecker, and is not the species figured by Packard in his monograph as C. angustiorata, Walker. I possess both species, and they are quite distinct. Figure 32 is, I think, Plagodis alcoolaria, not $P$. emargataria.

I may also call attention to the fact that there are some evident misprints in the "Key to the Families," on page 24, which will, I fear, make the use of the key difficult for beginners.

Lastly, I may point out that Dr. Holland does Dr. Dyar an injustice, unintentional of course, when he says on page 344 that he has overlooked in his catalogue the Cleora atrifasciata of Hulst, for, as a matter of fact, Dr. Dyar has placed that form just where Dr. Hulst himself (see Ent. News, VI., 43) said it should go, namely, as a synonym of Mesoleuca immanata. I must admit that this appears a strange position for a moth described as a Cleora, and as Dr. Holland has the type it is interesting to know his opinion of its specific value. 


\section{THE GENUS PSILOPUS OF AUTHORS.}

BY J. M. ALDRICH, MOSCOW, IDAHO.

In the Journal of the New York Entomological Society, X., 140, I 902, footnote, Mr. Coquillett called attention to a serious error of mine in my revision of what I called the Psilopinæe (Diptera, family Dolichopodidæ), by which I applied the new name Gnamptopsilopus to that portion of the old genus Psilopus containing the type species platypterus. But little investigation was needed to assure me that the criticism was just. This gave occasion for an overhauling of the literature of the group, and I undertook to ascertain what name ought to be used for Psilopus, which has been known for many years to be preoccupied. Some of the papers needed were hard to obtain, which delayed my task ; but the main difficulty was the host of subsidiary questions, historical and critical, which rose up to confront me. I have never found anything like it in previous excursions into the realm of nomenclature. I doubt very much if any two zoologists could independently investigate the subject and come to the same conclusion ; at least, there are a number of different names for which plausible arguments can be made. It would require a lengthy article to set forth all the queer questions connected with the case; I dare not attempt it, partly because it would not be worth the room, and partly because it would make subsequent change too easy. Instead of offering a choice of several names, I give my conclusions and a few notes, and particularly request that any future worker in the family who may wish to use other names for the genera will do as I have done-examine all the literature and then ponder the matter one year before making any change.

The two genera which I have formerly called Gnamptopsilopus and Psilopus should stand as follows :

Agonosoma.

Guérin-Méneville, Voyage . . . . sur la Corvette; Zoologie, Tome

II., partie 2 me, p. 293. Paris, 1838 (title page gives date 1830 ).

On the plates the genus is called Chrysosoma.

Fallén, Dolichopodes, 23, I 823 (Leptopus, preoc.).

Meigen, Syst. Beschr, Europ. Zw. Ins., IV., 35, I 824 (Psilopus, preoc.). Zeller, Isis, I 842,83 I (changes Psilopus to Sciapus).

?Bigot, Annales Soc. Ent., France, i 859, 2 I 5 (Margaritostylus, in part).

Rondani, Dipt. Italicae Prodromus, IV., I I, IS6I (changes Psilopus to

Psilopodius).

August, 1904. 
Schiner, Fauna Austriaca, Dipt., I., I8o, 1862 (Psilopus, Meig.).

Loew, Monogr, N. A. Diptera, II., 229 , 1864 (id.).

Aldrich, Kans. Univ. Quart., II., 47, I 893 (Gnamptopsilopus) ; Biologia

Cent. Amer., Dipt., Suppl., 364, 1902, table of species (id.).

Coquillett, Jour. N. Y. Ent. Soc., X., I 40, I902, synonymy of

Gnamptopsilopus.

Bezzi, Zeitsch f. Hym. u. Dipterologie, rgoz, 19r, adopts Sciapus.

\section{PSILOPODINUS.}

Bigot, Annales Soc. Ent., France, I 890, 269.

?Bigot, Annales Soc. Ent., France, I 859, 215 (Oariostylus, Megistostylus, Mesoblepharius, Condylostylus, Eurostomerus, Dasypsilopus, Heteropsilopus, Aedipsilopus).

?Bigot, Annales Soc. Ent., France, r 890, 26r-269 (Spathipsilopus, Eudasypus, Amblypsilopus, Tylochetus, Oariopherus).

Aldrich, Kans. Univ. Quart., II., 47, I 893 (Psilopus in restricted sense).

Notes.-I have seen all the literature cited except Zeller. The Smithsonian Institution kindly loaned me Guérin-Méneville.

The genera of Bigot, published in I 859 and I 890 , are very badly conceived, and not properly genera at all, nor even subgenera. The descriptions of the type species hardly allow a definite opinion as to their location in the two genera here adopted, but $I$ incline to place most of them in the second genus, with tegular cilia black. I chose to retain Bigot's name Psilopodinus for this genus for several reasons. First, sipho is mentioned among the types; second, it is not based on purely sexual characters (nor on much of anything else, I must admit); third, it is an advantage to retain this name from its resemblance to Psilopus, as the group includes Loew's larger section of Psilopus, and all that I referred to that genus in my revision.

The genus Agonosoma was supposed by its describer to differ from Psilopus by a more elongated third antennal joint and a somewhat different structure of the face and front. Two East Indian species were described, fasciata and maculiponnis. In these the antenna are yellow or ferrugineous, with tip of third joint infuscated. The figure of the wing of the first shows the third vein parallel at the tip with the fourth. These two characters are quite distinctive, and I think we may safely assume that the species also have pale tegular cilia, and are entirely congeneric with Psilopus platypterus, which should, therefore, be referred to Agonosoma.

The effect on nomenclature is as follows: In Loew's Monograph of N. A. Dolichopodidie, p. 244 , his first section of Psilopus, comprising those with black cilia of the tegulx, are now referred to Psilopodinus, excepting Fsilopus dimidiatus; the other section, with pale ciila, are now referred to Agonosoma, together with $P_{s}$. dimidiatus. In Williston's Manual of N. A. Diptera, I 896, pp. 77, 78 , substitute Psilopodinus for Psilopus, and Agonosoma for Gnamptopsilopus. 
SOME ORTHOPTERA TAKEN AT MOOSE JAW, ASSINIBOIA. BY A. N. CaUdell, Washington, D. C.

Last summer, on August $24^{\text {th }}$, a few hours were spent at Moose Jaw collecting Orthoptera. But few species were taken, and they are here listed for the locality. They were all taken on the open prairie, out a short distance from the town.

Chortophaga viridifasciata, DeGeer. Nymphs only taken.

Plilibostroma quadrimaculatum, Thom. But a few specimens taken.

Gomphocerus clepsydra, Scudd. This species was moderately common.

Arphia pseudonietana, Thom. (tenebrosa, Scudd.). Rather common, but not numerous.

Mestobregma kiowa, Thom. A single male taken.

Encoptolophus purvus, Scudd. One female specimen only taken. This species does not appear to have been previously reported from Canada.

Melanoplus atlanis, Riley. Apparently not very common.

Melanoplus Dausoni, Scudd. Only the slort-ivinged variety, tellustris, was taken. It occurred quite abundantly in the prairie grass.

Melanoplus infantilis, Scudd. This was the most numerous of any species noted.

Gryllus Pennsylvanicus, var. neglectus, Scudd. Five specimens of this insect were taken under a stone in a draw, or small hollow, on the prairie. Scudder has referred this insect to the synonymy, placing it as a synonym of Burmeister's G. Pennsylvanicus, but the smaller size and shorter elytra certainly entitle it to varietal distinction.

Nemobius fasciatus, var. abortıvus, n. var. Hopping actively about in the grass in and along the borders of the above-mentioned draw were numbers of a small Nemobius, which is very similar to $N$. fasciutus, but is uniformly darker, being nearly black, and decidedly smaller, as shown by the following measurements :

Length elytra, male 4.5 to $6 \mathrm{~mm}$., female 3 to $4 \mathrm{~mm}$.; posterior femora, male 4 to $5 \mathrm{~mm}$., female 5 to $6 \mathrm{~mm}$; ovipositor, female 6 to $7 \mathrm{~mm}$.

About three dozen specimens, a few more females than males, were taken, and they are very uniform in size and coloration. This is the small black species mentioned by Walker, on page 184 of the CaNADIaN Entomologist for July. Specimens were submitted to Prof. Blatchley. who says they may eventually prove a good species. They certainly form a valid variety, which may be called abortivus. Like vittatus, it is shortwinged. Except for the uniform black colour, it resembles the $N$. Utahensis of Scudder. 
[leprinted from JuUrnal of the Nkw York Entomological Socikty, Vol X.., No. 2, June, 1912.]

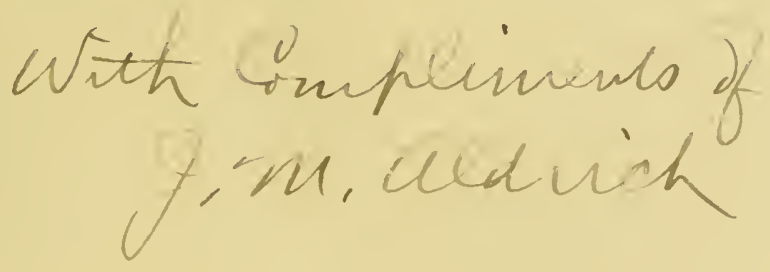

\title{
THE BIOLOGY OF SOME WESTERN SPECIES OF THE DIPTEROUS GENUS EPHYDRA. ${ }^{1}$
}

\author{
By J. M. Aldrich, \\ Moscow, IDA. \\ (With Plates VII to IX.)
}

The investigation partially covered by this paper was first suggested by a casual visit to the shores of Great Salt Lake in the summer of Igo8. The large number of new observations made in a couple of hours at that time indicated the existence of a rich and almost unexplored field. Through the liberality of the trustees of the Elizabeth Thompson Science Fund, I was enabled in the summer of I9II to visit the principal salt and alkaline lakes of the Great Basin and adjacent territory west and southwest. The present paper combines the facts gathered in both years and those previously published, pertaining to the biology of the genus Ephydra in the west.

The bodies of salt and alkaline water visited by me in I9I I, with dates of visits, are as follows:

Box Elder Lake, Uta

July 4 and 5

Great Salt Lake, Utah-

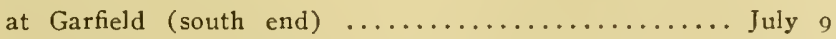

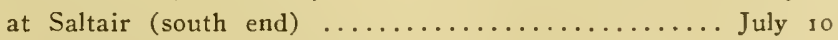

at Promontory Point (middle) ................ July is

at Lakeside (west side) ................... July I 2

Soda Lakes near Hazen, Nevada ............ July 13 and 14

${ }^{1}$ Being a portion of the results of an investigation carried on with the aid of an appropriation from the Elizabeth Thompson Science Fund. 
Pyramid Lake, Nevada ..................... July 16

Winnemucca Lake, Nevada ................... July 17

Mono Lake, Cal. ...................... July 21 to 24

Walker Lake, Nevada ...................... July 25

Owen's Lake, Cal. ........................ July 28

Pacific Ocean at Santa Monica, Cal. ............. July 31

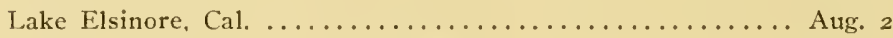

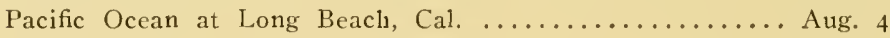

Borax Lake near Clear Lake, Cal. ................. Aug. 8

San Francisco Bay near Palo Alto, Cal. ................. Aug. I I

There are but four species of western Ephydra to report upon, as several of the names until recently in use are now known to be synonyms. All four of these are very abundant insects in their peculiar habitat, however, and one has been an important food for man. Several other species of the genus occur in the west, but their immature stages have not yet been found; so far as known they are all very rare. In another paper it is proposed to give a systematic treatment of the adults of all the western species.

\section{Ephydra gracilis Packard.}

Packiard, Amer. Journal of Arts and Sciences, 3d series, I, 104, 1871, puparium only.

B. J. Jones, Tech. Bull., Cal. Ex. Station, I, No. 2, p. 159, 1906 (adult, as Ephydra cinerea).

Packard's original description, upon which the use of the name gracilis depends, is so brief that I quote it entire:

"These insects occur so abundantly where they are found, and can be so easily reared, that I venture to name another form from Great Salt Lake [the preceding had been from Clear Lake, Cal.J. M. A.], specimens of the puparia of which have been communicated by Professor Verrill, from the collection of Mr. Sereno IVatson; and by S. A. Briggs, Esq., of Chicago. It is much smaller and slenderer than any of the preceding species, the smaller specimens being .25 inch long, the largest .50 inch. The respiratory tube is much longer than in any species known to me, being in several specimens as long as the body itself; the branches into which it subdivides being over one third as long as the base of the tube. The body is of the shape of E. halophila, but is much slenderer, while the feet are larger and more prominent." 
This description, as will be seen, consists only of a few general rentarks about the puparium, comparing it with that of two other species; it would perhaps scarcely be recognizable but for the reference to the exceeding abundance of the species in Great Salt Lake. The description is especially unsatisfactory from the omission of a striking and easy mark of distinction, the basal filaments of the anal tube, which separates the species from all other American Ephydras of which the early stages are known. But it is certain that Packard was describing a strikingly small Ephydra common in Great Salt Lake, and there is but one species, whether he described it well or not.

Jones was dealing with specimens from Southern California, and was naturally unable to identify them from Packard's description. Mr. E. T. Cresson, Jr., examined Jones's' types and compared them with material from Great Salt Lake; he is inclined to retain the name cincrea for a large variety, but my material does not justify this.

Adult (Pl. VII, Fig. 1).-Length, 2.3 to $3.5 \mathrm{~mm}$; of wing 2 to $2.9 \mathrm{~mm}$. General color opaque gray, paler below and with a slight greenish tinge above; front moderately bright green; legs infuscated, knees and greater part of the tarsi yellow; wing-reins yellow at base.

Head of typical Ephydra shape, the face not shining below the antennæ, front large, shining green except when viewed from in front with nearly frontal light, when it is ashy opaque; lower half of front with scattered minute hairs directed somewhat backward, no decussate small bristles; no noticeable impressions on front; frontal orbits pollinose, gray, with three bristles curving over the eye and a few small hairs arising between them; the edge of the front next the orbit is covered for a narrow space with a duller pruinosity; ocellar triangle pollinose, with two pairs of divergent hairs behind the single pair of large, divergent bristles; two vertical bristies each side, the inner curving directly mesad, the outer almost exactly laterad; occiput opaque, orbits not different, with only a small row of hairs. Antennæ black, gray pruinose, very short, rather far apart; first joint hardly visible, second nearly as long as third, with a slender erect hair at base and a notch in apex above just behind the arista; third without lateral hair, arista almost basal, short, thick at base, moderately plumose under high power. Face almost white all over, with scattered small black hairs and a row of three or four divergent and upturned long hairs each side above the middle, extending laterally close to the lower edge; lower edge of face with quite short and thin hairs hanging down, about the same in both sexes. Cheek behind lower part of eye rather large, with small hairs and one or two somewhat larger. Proboscis thick and short, black: palpi indistinctly yellowish.

Thorax opaque gray, with scattered small black hairs and the usual 
black bristles for the genus, both on dorsum and sides; scutellum somewhat elongated, convex, hairy and with four bristles; sternopleural only one; several small bristles at posterior edge of mesopleura, one larger; halteres yellow. Abdomen rather uniformly gray pruinose with a little greenish tinge, first segment short, next three of equal length, fifth a very little longer; hypopygium small, narrow, blackish, with two yellowish stiff processes projecting forward as far as the middle of the fourth ventral; the longest hairs on the abdomen are about the apex and before the incisures near the sides, but they are hardly bristle-like. Coxæ and femora concolorous with thorax, the trochanters and knees yellow; tibix varying from yellow to the color of the femora, the front ones usually paler than the others; tarsi mostly yellow, variably infuscated at tip, longer than their tibix, the three middle joints of equal length, claws long, straight, black, no pulvilli. The hind femora have a long shining streak on the inner side, and the hind tibix have a short shining streak at the tip behind. Wings of ordinary structure, yellowish at base, especially the veins.

Larva (Pl. VII, Fig. 2).-Length in a full-grown, average specimen, of body, $10.6 \mathrm{~mm}$.; of anal tube to the fork, $4.9 \mathrm{~mm}$.; of each terminal fork, $1.6 \mathrm{~mm}$.; of each basal fork, 2 mm. Color white, somewhat transparent. Eight pairs of rather long prolegs, the members in each pair united in a single tubercle in the basal third, but entirely separate on the remainder of their length; in front of the segment bearing the first prolegs there are three apparent segments, the foremost retractile, containing the jaw-capsule; the jaws, as in related forms, turn down in the form of hooks, and are not opposable. Behind the last pair of prolegs the body narrows suddenly into a long anal tube, which gives off close to the base on the under side a pair of long filaments, and at its tip divides into a pair of somewhat shorter filaments. The hindmost prolegs have a longer common tubercle and a shorter divided portion than the rest.

The anal tube is considerably retractile, and varies in length in different preserved specimens. It contains two trachex, which continue to the terminal fork, where one leads into each branch and ends in a vestigial spiracle at the tip. I doubt if these spiracles are ever put to the surface of the water; I have not yet seen it done, so I conclude that the whole structure has changed its mode of functioning, and operates as a tracheal gill.

Puparium (Pl. VII, Figs. 3,4).-Length of body in an average specimen, to the last prolegs, $8 \mathrm{~mm}$; ; anal tube so variable that it can hardly be estimated, perhaps five or six mm. would be about the usual total length beyond the last prolegs. The form of the insect is much changed from the larval stage. The thickest part of the body is in the region of the third pair of prolegs, and it tapers suddenly in front, more slowly behind, so as to be somewhat fusiform with the thickest portion well before the middle. The prolegs toward the anterior end are small; the front pair are almost indistinguishable and have no hooks; the successive pairs are each a little larger, but only the last three pairs have hooks and are of about the same size as in the larva. The last pair, which in related species hold the insect attached 
during the pupal period, are here but little if at all turned forward, and do not seem to serve an important function in this species. Behind the last prolegs the base of the anal tube looks like another body segment, those preceding it being about as slender as it is; the continuation of the tube is not strongly chitinized, but thin-walled and pale in color. The diverging terminal tubes each contain a trachea, which continue separate down into the body; the pair of filaments at base of tube do not seem to have trachex, at least they have no vestiges of spiracles at the apices as the terminal branches obviously have. At the front end of the prparimm, there is a flattened space above, well defined, extending to hind edge of the segment bearing the first prolegs-only a short space, as the anterior segments become very small as the puparium forms; this plate cracks from the front end backward along each side, and sometimes allows the escape of the fly without the breaking off of the entire anterior end of the puparinm, as is supposed to be the case in the group Cyclorhapha, to which Ephydridx belong.

Pupa.-Cpon removing the puparim, the enclosed pupa is readily obtainable. It is white in color and shows the outlines of the members of the future fly. The large proboscis is flattened down upon the prosternum; on each side of it the three legs are closely placed in regular order, and the wing follows the last leg; most of the dorsum of the thorax and abdomen is exposed, the wings being bent down along the side and of small size. It is difficult to make out many inportant features in the pupa, there being still one covering membrane over the future adult, and the tissues of the latter being still in an unfinished condition. The appearance is like the jupa of E. hians, in the half-tone, Fig. 15.

\section{HABITS.}

Distribution.-The insect is abundant in all parts of Great Salt Lake. It was reported to me by Mr. D. W. Coquillett as being represented in the United States National Museum from Salton Sea, Cal., and Tucson, Ariz. The material to which Jones gave the name of E. cincrea came from Southern California, without designation of locality. Recently a single specimen has been sent me by Professor C. F. Baker which was collected at Laguna Beach, Cal, which is on the Pacific Ocean. I have not learned the exact labitat of the insect in this case, but I presume it was found adjacent to sonte salt waters back from the sea-beach; it would be surprising to find it passing its larval stages in actual seawater.

My observations on the habits of the species were all made at Great Salt Lake, in the last of July, igo8, and the early part of July, I9II.

Egg and Early Larval Stages.-Of these I know nothing from 
direct observation. Since most of the flies after maturity live on the surface of the water, the eggs no doubt are dropped directly into the water.

Food Matcrials.-There is an alga in the lake everywhere common, of the Nostoc group, its pulpy masses rolling up and down the beaches with the waves, and often forming rotting deposits of horrible odor along the npper beach as the level of the lake falls in summer. This I take to be the food of gracilis and also of the brine shrimp, Artemia fertilis, which are generally said to be the only forms of animal life found in the waters.

Habits of the Older Larect.-These seem to be suspended in the waters everywhere, wriggling rather aimlessly, often hard to see because of their half transparency. They do not show much disposition to keep near the surface; I could see them at a depth of two or three feet, which is as far as they could be made out on account of their delicacy. The probably occur at greater depths. That they lo not come to the surface to breathe seems not to have been noted in this or any other species before, but I feel confident of iny prolonged observations on this point. The long tube and its filaments must function as a tracheal gill, the spiracles at the tips being vestigial, as the anterior pair of spiracles certainly are. The pupre show close to the anterior end the protuberant endings of a trachea on each side (Pl. VII, Fig. 7, shows the same in hians) so that if these and the posterior ones were functional we should have an anphipneustic larva. The anterior spiracles, however, are more vestigial than the posterior ones, and may be considered to have lost their function at an earlier period.

Puparia.-It is only in the pupal stage that the inconceivable number of these flies present in the lake begins to nuake an impression on the observer. The puparia are buoyant, regularly containing gas in the otherwise vacant space at the ends and around the pupa; moreover, they become attached to each other by the hardened and somewhat recurved forks of the anal tule, so that vast masses float along together. At Promontory Point I could see occasional large brown patches off shore, which I was assured were of this nature, and I was told that they were continually drifting lown the Bear River Bay side of the Point, covering acres of water at a time and six inches deep, one informant said ( $I$ think he said forty acres). 
The shores of the lake everywhere are more or less covered with windrows of puparia, which frequently form dark ridges that can be seen for a long distance. One of my half-tones (Pl. VIII, Fig. 8) shows the little bay on the north side, where the cutoff reaches the Point from the east. Here considerable drift accumulates, and the fly puparia form a mass filling the water close to shore, and a foot or more deep above the water for some distance; all the dark color in the water and along the edge is simply a collection of millions of puparia. The other half-tone of this subject is Pl. VIII, Fig. 9, which shows the shore on the south side of the railroad looking west. Here also the broad dark margin of the water is composed of puparia. Fig. 3 shows a small cluster of puparia held together by the diverging branches of the anal tubes. Fig. 4 is a small mass of puparia taken from a dry windrow on the beach near Garfield in 1908 .

Adults.-The adults are found on the surface of the water all over the lake, but along the beaches they gather in large numbers, probably because they emerge there from the windrows of puparia that wash up. On July 3 I, I908, I visited the shore near Garfield, at the south end of the lake. Near the rocks which come down to the edge of the water at the county line, I waded in and investigated the flies. At that time the surface of the water from the shore out for a distance of about eighteen feet was perfectly covered with the adult flies. They made a black belt along the beach that was visible for several miles, or as far as the shore line could be seen. They were crowded closely together, and when disturbed by my near approach they would rise only a few inches and immediately settle again. They extended up the beach a few feet above the water also, so the average width of the mass was over 20 feet. I thought that there were more than 25 flies to the square inch; in fact, double that seems a small estimate. The minimum estimate would give about $370,000,000$ flies to the mile of beach.

In bathing at Saltair. I heard one bather say to his companion, "Don't go near those piles, you'll get covered with gnats." This was in allusion to E. gracilis, which I found on examination was present in large numbers, but as I could see it on the surface of the water everywhere it did not seem especially bad about the piles. There is occasional complaint about "gnats" by the bathers, but the flies 
are very small and inconspicuous and do no harm further than to walk on people.

On the Southern Pacific cut-off west of Ogden the fly appears in a new rôle. The train-men pass through the train a few minutes before the lake is reached, shutting the windows "on account of the salt-flies," as I heard one say. It appears that the suction of the moving train raises the flies much above the usual level of their flight, and they come into open car windows by myriads. Even with care in closing the windows some will find their way in, where they become a nuisance by walking on passengers and on the tables in the dining cars. I had no difficulty in finding some of the flies in the latter situation as far west as Reno, Nevarla, and I doubt not that they may be found after the cars reach Oakland. Reno is approximately 500 miles west of Great Salt Lake.

Nor is the story of gracilis yet completed. In the summer evenings they congregate on the rails of the cut-off to such an extent as often to stop the gasoline motors used by track-men, and even sometimes to stall freight trains. P1. VIII, Fig. Io, shows as good a picture as I could make with a regular kodak of flies on the rails; it was taken on the morning of July I2, I9II, at Lakeside, on the western shore of the lake.

From Saltair bathing pavilion I walked ashore, and near the railroad in a little bay I found a place where the salt water had evaporated down until it was full of salt crystals. Even here the larvæ of gracilis were active and unconcerned. I found none of them, however, in fresh water a short distance away from the lake, nor in that which was tolerably brackish, although a few adults were present sometimes at a little distance from the salt waters. Professor Voorhies at the University of Utah informed me that he had left larva of gracilis in water that had evaporated down until it was covered with a crust of salt, and even in this condition the insects were active; also that he had on one occasion kept some of them in a histological fixing solution over night and for several hours of the following day, before they succumbed to the poison. ${ }^{1}$

${ }^{1}$ Wilcox, in Anat. Anseiger, XII, 278, describes the remarkable resistance of a dipterous larva from stagnant salt pools at Newport, R. I. He identified it with doubt as a Helophilus, but I suspect it may have been an Ephydra. 


\section{Ephydra hians Say.}

Say, Jour. Acad. Sci. Phil., VI, 188, 1830 . Original description of adult; habitat Mexico; reproduced in Say's Complete Works, II, $37 \mathrm{I}$.

Loew, Centuries of N. A. Dipt., VI, 88, 1865. Adult described as Ephydra crassimana; habitat Mexico.

Packard, Amer. Journal of Science and Arts, 3d ser., I, 103, 1871. Larva, pupa and puparium described as Ephydra californica; habitat, Clear Lake, Lake Co., Cal., supposed to be salt water: puparia from Mono Lake probably the same.

Williston, Transactions Conn. Academy, VI, July, I $88_{3}$, sep. p. 4. Describes adult supposed to be that of californica Pack., from Soda Lakes, Nevada; notes on larvæ in these lakes and at Mono Lake, and use as food by Indians.

Williston, North Amer. Fauna (Bull. 7 pt. 2, Div. of Ornith. and Nammal., Dept. of Agric.), p. 257. Adult described as Ephydra tarsata, from Owen's Valley, Cal. ${ }^{1}$

Adult (P1. IX, Fig. 18).-Black, opaque gray all over except the front, which is shining dark green; first joint of front tarsus considerably thickened in the male. Front with scattering small hairs except in the somewhat depressed middle portion, toward the sides anteriorly with three or four pairs of bristles of different sizes, the largest decussate; the shining part of front narrowed anteriorly, and the opaque sides becoming wider; two vertical bristles on each side, the tips of the inner pair almost meeting; ocellar triangle opaque, with three pairs of bristles, becoming smaller posteriorly; frontal orbit with four curved bristles; face prominent in the middle, rather densely hairy all over, longest on the lower edge; rather bushy hairs below the eye and behind its lower part; antennæ of medium size, first joint distinct, second with an erect hair, third without a lateral hair, arista short, thick at base, nearly bare.

Dorsum of thorax with plentiful coarse hair, besides the usual bristles; many of the hairs approach the size of bristles, making the chrtotaxy confused-however it is easy to count six dorsocentrals, 3 humeral, 2 presutural, 2 large median prescutellar; scutellum with coarse hair and two pairs of bristles, sometimes another small pair between the main ones; pleura concolorous, the mesopleura, propleura and sternopleura all hairy, mesopleura with a row of bristles on hind edge, stenopleura with one bristle; metanotum and remainder of pleura bare.

Abdomen concolorous, the greenish ground-color showing through a little more than on other parts of body, both dorsal and ventral sides coarsely hairy; hypopygium of male small, generally retracted; tip of abdomen of female with the usual two spines curved backward below.

${ }^{1}$ In making out the above synonymy I have been aided by suggestions from E. T. Cresson, Jr., and the late Mr. Coquillett, of the National Museum. As will appear, we have to deal with a very widespread form, which has been partially described several times. 
L.egs wholly opaque gray pruinose, tarsi with brush-like pale hairs bclow, front metatarsus of male somewhat thickened, and with curled hairs on outer side, making the middle of the joint appear wider than it is; hind femur with a wide shining black area on the inner side, beginning near the base and extending beyond the middle; hind tibe with a very narrow shining black line on the hind edge at the tip, extending up the tibia only one sixth its length. Claws very long and straight, no pulvilli.

Wings as in halftone, veins black, brownish-yellow at base; costa with a few short spinules beyond middle.

Length, 3.2 to $5.6 \mathrm{~mm}$; of wing, 3.5 to $4.5 \mathrm{~mm}$.

\section{Distribution.}

Washington: Soap Lake (C. V. Piper, in State College coll.). Lake Como (U. S. National Museum, reported by D. W. Coquillett).

Oregon: Albert Lake (U. S. N. M.).

California: Borax Pond near Clear Lake. Clear Lake (Packard -probably was actually the same as the preceding, as Clear Lake is fresh water). Mono Lake (several collectors). Owen's Lake and Valley (several). Borax Lake and East Lake ( U. S. N. M., without further information as to where these are).

Nevada: Soda Lakes (Williston). Lagoon south of Pyramid Jake (U. S. N. M.). Pyramid Lake.

Utah: Great Salt Lake (U. S. N. M.).

Wyoming: I2 miles north of Lusk (U. of Kansas coll.; no data as to body of water).

Nebraska: Salt Marshes near Lincoln (L. Brıner).

Minnesota: Red River Valley (Washburn; no data as to body of water).

Mexico: Guanajuato and Lake Texcuco (U. S. N. M.). Without locality (Say and Loew).

Pupa (Pl. IX, Fig. 15).-Specimens of these were extracted from the puparia and photographed. As in gracilis, they seem to present no characters of importance in classification or biology.

Puparium (P1. IX, Fig. 16).-Length $7 \mathrm{~mm}$; of tube to fork, $2.6 \mathrm{~mm}$; of fork, 1.1 $\mathrm{mm}$. Spindle-shaped, strongly tapering and up-curved in front, more gradually tapering and straight posteriorly; first four pairs of prolegs small but provided with strong hooks; last four pairs large and protuberant, the last pair largest and longest, and the hooks reversed in position; on the posterior side of this segment are some small protuberances which in some cases appear like additional but rudimentary prolegs, but they vary in development in different specimens; there are some bulging spots on the shell on 
the two segments preceding this one, but they have no regular arrangement. The dorsum of the puparium is pigmented in a broad irregular vitta almost the whole length, as in the larva. The anal tube has no basal forks or filaments; the tube and its terminal forks are more uniform in length than in the larval stage, being of a hard consistency. The segment which bears the first prolegs has a flattened surface above, which continues to the anterior end of the puparium; this somewhat shield-shaped piece splits along the sides, and many of the flies emerge from the crack without pushing off the entire front end (Fig. 16, arrow) as is supposed to be characteristic of Diptera cyclorhapha. The flat upper piece is readily removed, and is shown in Fig. 7 . It bears at the sides the rudiments of two spiracles. The lower portion of the anterior end also readily cracks off, just behind the first prolegs, and is shown in Fig. 17; it contains the remains of the mouth-parts of the larva -a flat black sclerite embedded in the integument, and the jaw-capsule frame farther back, to the front edge of the latter being attached two long curved hooks, which in the figure seem to connect it with the former, but which really bend downward at their points. As the pupa forms it retracts from the anterior end of the shell and leaves these larval organs outside.

Lar'a (P1. IX, Fig. 13).-The fullgrown larva measures about $12 \mathrm{~mm}$. in length in alcoholic specimens; the length of the anal tube and its forks is highly variable and depends entirely on the amount of retraction that has taken place; generally it is much shorter in preserved specimens than it is observed to be in fresh material. The most prominent characteristic of this species is the highly pigmented stripe down the back, almost as wide as the larva, with irregular edges, narrower toward the front edge of each segment and then gradually widening to the posterior border. This pigmentation shows under the high power of the compound microscope as a covering of minute spines, a sort of shagreen; but with moderate powers it simply appears like a blackish pigment. The eight pairs of prolegs are conspicuous, as in allied forms, the last pair being much the largest, with the hooks reversed in position, enabling the insect to grasp a solid object between them and the next pair anterior, or sometimes the second pair anterior. This is a very characteristic feature of the species. The anal tube bears no filaments at base, and the apical ones emerge directly from the open end of the tube, into which they can be drawn so that only the tips are visible. The spiracles at the end of the two forks appear to be non-functional, and as in gracilis the organ serves as a tracheal gill.

The part of the insect anterior to the segment bearing the first prolegs is considered by Brauer to consist of five segments (Denksch. Kais. Ak. Wiss., XLVII, 39, 1883), but of these only three can be discerned, the other two being retracted in the anterior end. The second of the visible segments bears on its under surface a large, transversely oblong black spot or sclerite: this secms to be a hardened spot in the integument for the attachment of some of the muscles of the jaw-capsule. There is no true head, the retracted part being mainly the jaw mechanism. Two minute two-jointed antennæ can sometimes be detected. but they are capable of retraction. The jaws are 
modified so that they work vertically, as in all this group; in hians they are provided with a transverse row of teeth.

As in the case of other cycloraphous dipterous larvæ, distinct stages separated by moulting are not found. I have numerous newly-hatched larvæ, and a few of intermediate sizes. The youngest sizes differ from the full-grown in several minor features, especially in the absence of dorsal pigmentation and of the black plate on the ventral side of the (apparent) second segment; also in the presence of a large number of hooks in the mouth, almost like those of a pair of prolegs. These last are retractile, and not visible in some small specimens: I am unable to determine at what stage they are lost. They are well developed in larvæ $2.5 \mathrm{~mm}$. long, and in smaller ones.

Egg (Fig. 11).-Length .8 mm.; width, greatest, one-third the length, least, one-fourth the length. Slightly curved; white in color. Without any hairs or appendages, quite unlike those figured by Jones for E. millbra. Not attached to anything, as far as my observations go.

\section{HABITS.}

The adtult flies are abundant at the edge of the water of many western salt and alkaline lakes and ponds, as indicaterl to some extent under distribution. I first observed them in July 3I, I9o8, near Garfield, Utah, on the shore of Great Salt Lake. While gracilis occupied all the water's edge and extended ont on the surface of the lake for some distance, hians occurred in numbers a little farther up the lake beach, where there were windrows of rotting material that had been washed up at a higher stage of water not very long before. The two species seemed not to mix much, and my inpression at the time was that hians bred in the rotting Nostoc, etc, of the windrow. On visiting the lake at several points in I9II, at a season when gracilis was not so overwhelming in numbers of adults, I found hians occasionally abundant close to the margin of the water and walking out on the surface for a few feet. Neither of these two species appears to live in water of slight alkalinity or saltness, except when it is very close to more dense water. To illustrate, at Promontory Point I was taken to inspect a spring a mile and a half up the east side of the ridge: it was about half a mile from the lake, and several hundred feet above it. The water was only brackish to the taste, but both gracilis and hians were abundant. The small outflow was lost in the dry earth in a short distance but probably sometimes did reach the shore, giving the flies a chance to follow it 11. Again, Pyramid Lake is nearly fresh water, somewhat alkaline to the taste, but probably passable to 
drink in an emergency, I found hians in small numbers near the inlet; but this was within perhaps a mile of "Mudhen Lake," a much more alkaline pond close to the Truckee River just south of the Lake (doubtless the one called a lagoon in the distribution, above), where I was inforned by an Indian that the Kootsabe was abundant-this same fly. Except in these two cases, I have not found hians except at the decidedly strong waters, but it appears to thrive well in both salty waters and alkaline, while as far as known at present gracilis confines itself to the former only. Neither fly secms to spread much from the immediate edge of the strong waters, though near Garfield I found gracilis a few hundred feet back from the main lake, at the edge of nearly fresh water. Professor Voorhies told me that he had not tried the experiment of rearing gracilis in pure water, and I did not stop long enough in a place to undertake it myself.

Adults of hians have the unusual habit of entering the water and walking about on objects below the surface, enveloped in a globule of air. They cannot descend unless they can have some solid object to hold to, as they are quite buoyant when below the surface. I repeatedly saw them walking in this way in Mono Lake, clinging to stones, wood, grass, cloth, or any firm substance; when they wished to come to the surface they did so by letting go and floating straight up, when the enveloping bubble bursts at the surface, and the fly is left standing unconcernedly on the top of the water. This is very common, and in one case I found eggs that had been laid on an old cloth some distance below the surface, on which I had seen numerous flies. This is not the invariable mode of laying eggs, as a great many of the flies are far from shore, over deep water, and have no way of getting below the surface. It seems pretty certain that in such a situation the eggs are simply dropped in the water while the fly rests on the surface.

The larva are generally found near the bottom of the water. They wriggle a good deal, but do not come to the surface for air, having become modified in the same way as gracilis in regard to respiration. I never saw hians about the Saltair bathing pavilion, and think it likely that both larvæ and adults generally remain rather close to shore. The food of the larve I did not investigate, thinking that it would be a simple matter to open some of the preserved specimens and identify the contents of the proventriculus; the operation proved 
very unsatisfactory, however. In Mono Lake, where I made most of my observations on this species, there seemed almost nothing in the beatiful, clear water of a vegetable nature. This larva and the brine shrimp Artemia monica were the only visible animals.

When the larva have reached their full size, the outer integument hardens into the puparium. Before this takes place the insect has already assumed the fusiform shape of that stage, and has taken a firm hold on some solid object for attachment. The hold is taken by grasping the object between the last prolegs and the next pair forward, or the second pair forward. They attach to any firm object. roots of vegetation being much used. At the small Soda Lake in Nevada, I took up a piece of string ont of the water which was literally covered. They often attach to each other, and sometimes an empty but still attached puparium is utilized by thrusting the last two or three segments into the open end and pressing the next prolegs against the outside. When the larva contracts into the pupa, the space left within the puparium becomes full of gas, so that the insect floats if detached, although normally it remains in the bottom of the lake. The fly on emergence is enveloped in the bubble of gas, and floats at once to the surface; this process I witnessed several times.

Mono Lake is subject to violent winds in the latter part of summer, and the disturbance of the lake loosens many of the puparia, so that they float to the surface and wash ashore. The late Professor Wm. H. Brewer, of Yale, made some observations here in July, I863: I quote a portion of his letter to Williston (published by Williston. Trans. Conn. Acad., July, I $\left.88_{3}\right)$ :

"They drift up in heaps along the shore, and hundreds of bushcls conld be collected! They only grow at certain seasons of the year. and then Indians come from far and near to gather them for food. The worms are dried in the sum, the shell rubbed off by hand, when a yellowish kernel remains, like a small yellowish grain of rice. This is oily, very nutritious, and not unpleasant to the taste, and, muler the name of koo-chah-bec (so pronouncel), forms a very important article of food. . . My guide, an old linnter there, told me that everything fattens in the season of koo-chah-bec; that ducks get very fat, but their flesh tastes unpleasantly from it, and the Indians get fat and sleek."

My stay at Mono Lake was July 2I-24, I9I I, and I was informed 
that the collection of the fly for food would not begin until about September I. None was left over from the previous year, so I was disappointed in seeing either the material after preparation or the process of putting it up. However, I talked with both Indians and whites about it. There are only a few Indians who collect the material now, although it is known anong all the older Indians of the tribe. The name of the food is better spelled "koo-tsabe," accented on the first syllable, the last two letters forming an obscure syllable in which it is hard to distinguish whether the consonant is b or v. "Fat Joe" pronounced it for me many times and I listened very attentively; when I told him it had not been so recorded by earlier investigators, he chuckled and replied in his free and easy English, "Well, you understand I'm giving you the real thing." White people at the lake emphasized the amount of time required to free the little dried pupæ from bits of puparium, dirt, etc.; they thought it hardly worth while for anyone to work at it whose time had any value.

Most of the Pah-Ute Indians are now on reservations, one south of Pyramid Lake and one at the north end of Walker Lake, and only a few live near Mono Lake, where they eke out an existence on koo-tsabe, dried caterpillars (which I have reported on elsewhere) and pine nuts, adding a minimum of white man's "groceries."

The accompanying half-tones of the pupæ will give some idea of the food material that the fly makes. It has been reported that it was also collected thirty or more years ago by Indians of the same tribe at the two small soda lakes near Hazen, Nevada.

The loss of my camera with all my exposed films in it, while I was at Mono Lake, makes it impossible for me to give any illustrations except from the material brought home-much to my regret, for the lake and surroundings are very beautiful and picturesque.

The main centers of this species might be said to be Mono Lake, Owen's Lake, and Great Salt Lake-in all three they are exceedingly numerous.

I camnot forbear to include a brief extract from Mark Twain's "Roughing It," about the characteristic fly of Mono Lake, as it is true to life: "You can hold them under water as long as you please they do not mind it-they are only proud of it. When you let them go, they pop up to the surface as dry as a patent-office report, and 
walk off as unconcernedly as if they had been educated especially with a view to affording instructive entertainment to man in that particular way."

In Williston's Manual of North American Diptera, 2d edition, I896, p. I09, there is a quotation from a letter written by Professor Penafiel, referring to a species said by Williston to be E. hians, which is used as food at Lake Tezcuco, an alkaline lake about a hundred miles west of Mexico City. The quotation follows:

"It is of the eggs of this insect that the greater part of what is known as Ahuatle is composed and which is now used by the natives who have preserved the customs of the ancient Aztecs. The eggs are cleaned and ground into flour, and are prepared by mixing with hens' eggs and fried with fat into small cakes. The larvæ are also used as food under the name of Puxi."

Packard, in a footnote to his second paper on "Insects Inhabiting Salt Water," quotes something similar from a book called "Anahuac," by E. B. Taylor, published in London, in 186I. The quotation is as follows: "A favorite dish here (Tezcuco) consists of flies' eggs (Corixa femorata and Notonecta unifasciata, according to Menneville and Vielet d'Aoust) fried. These eggs are deposited at the edge of the lake, and the Indians fish them out, and sell them in the market place. So large is the quantity of these eggs that at a spot where a little stream deposits carbonate of lime, a peculiar kind of travertine is forming which consists of masses of them imbedded in the calcareous deposit." Packard adds without specifying his authority, "The flies which produce these eggs are called by the Mexicans 'Axayacatl' or 'water face.' The eggs are sold in the market, pounded and cooked, and also in lumps au naturel, forming a substance like the roe of a fish. This is known by the characteristic name of 'ahua-utli,' that is, "water wheat."

It seems that the Diptera and the Hemiptera are mingled together in the quotations; only an investigation by an entomologist at the lake can clear up the confusion. Probably the egg state is not used in either insect.

There remains only a brief note to add about the identity of Packard's Ephydra californica. After I learned that Clear Lake is a body of fresh water, not salt as Packard supposed, I inquired about any small bodies of alkaline water in the vicinity; in fact, Professor 
A. J. Cook, now Horticultural Commissioner of California, told me of one before I could ask him. Later Dr. E. C. Van Dyke gave me full directions about reaching the place. It is a small, strongly alkaline pond close to the shore of Clear Lake, some three or four miles south of Soda Bay, and is called Borax Pond or Borax Lake. I made a special trip from San Francisco, taking two days time, and was successful in collecting $E$. hians at this borax pond. This, I think. makes it reasonably certain that californica is a synonym of hians.

\section{Ephydra subopaca Loew.}

Loew, Centurics, V, 99, 1864. Adult described from Connecticut.

Packard, Proceedings of the Essex Institute, VI, 46, 1868 (issued March, 1870); puparium and adult described as Ephydra halophila, a preoccupied name; from brine at Equality Salt Works, Gallatin Co., Ill. Synonymy by Coquillett, in litt.

Johnson, Proe. Acad. Nat. Sciences of Philadelphia, 1895, 339, occurrence at Charlotte Harbor, Fla.

Smith, Catalogue Insects of New Jersey, s 899, 693, occurrence in New Jersey; second edition, 1909, 807 , same, several localities.

Johnson, Entomological News, XV, I63, I904, oc. at Atlantic City and Seaside Park, N. J.

Adult (PI. VII, Fig. 5).-A yellow-legged species with rather dense yellow pollen, front metallic blne-green, the fifth segment of the abdomen in the male nearly twice as long as the fourth.

Front metallic blue-green, bright, in the female with a pair of small decussate bristles on the lower part of the front and several hairs above and below these as well as a few scattering small hairs along the sides of the shining portion; in the male these hairs and bristles of the front are little developed; three orbital bristles, with hairs intermingled; two verticals each side; behind the main pair of ocellar bristles are two pairs of hairs; orbits yellow-pollinose. Face yellow-pollinose, with a small shining bluish spot in the median line below the antennx, covered with small black hairs and two transverse rows of bristles, one of which is directed downward along the margin of the mouth and is composed of long bristles in the female; the other follows the upper edge of the protuberance and the bristles bend outward and upward, especially those near the middle. Eye small and oblique, one large bristie on the broad cheek. Palpi yellow. Thorax yellow pollinose, dorsum a little shining in some specimens (when abraded), covered with small black hairs. Dorsocentrals 4 (I before the suture), prescutellars one median pair, humerals 1 and several hairs, posthumeral I, presutural 1 ; scutellar two pairs; before the scutellum the hairs are noticeably long. Mesopleura hairy except on the front part, on its hind edge with a row of long hairs and one bristle; stenopleura hairy and with one bristle. Tegula yellow, with abundant pale 
yellow silky hairs. Halteres yellow. Abdomen concolorous with thorax or more greenish, with black hairs, longer on the posterior edge of the segments, fifth segment in male nearly twice as long as fourth on dorsal side, ventrally it is entirely cut away to receive the large hypopygium, which has a pair of yellow processes extending forward one third the length of the fourth segment. Legs usually yellow, middle and hind coxæ blackish, tarsi somewhat infuscated toward the tip; front femora with some bristles on the outer and upper side; hind femora with a long shining area on the inner side, destitute of hairs, extending the whole length; hind tibia with a narrow shining streak on the hind side, from below the middle to the apex. Wings yellowish, veins yellow on basal half.

Length, 4 to $5 \mathrm{~mm}$; of wing, 3.5 to $4.5 \mathrm{~mm}$.

This species varies in several ways: the yellow color of the pollen may vary to whitish, especially on the face; the color of the legs may be considerably infuscated, especially on the femora; the hairs of the front may vary considerably in size; and the shining spot on the upper part of the face may be absent. As all these variations may occur in a lot taken together, they do not indicate specific differences.

Larra.-My material is far from abundant, but will allow a comparative description with hians. The larva of subopaca differs in not having the dorsal pigmentation and the black integumental plate below the retracted jawcapsule. The color is almost white, but the tips of the forls of the anal tube are very black, contrasting more with the general color than in hians. There are no basal filaments from the anal tubes. The proportions of body and tube are about as in hians, but the size a little smaller.

Puparimm.- There are faint pigmented spots on the dorsum. The sixth and eighth pairs of prolegs are uniformly large, the last with hooks directed forward; these two pairs are used in grasping a support while in the pupal period, the anterior five and the seventh being small but with good-sized hooks. The color of the integument varies but is generally light, and in many specimens the macrochetx of the pupa can easily be seen through the puparium-often indeed small hairs as well. The flat or concave region of the anterior end above is strongly marked, and the rudimentary spiracles stand out laterally on the (apparent) first segment, their protruding part divided into three or four processes.

\section{Distribution.}

Massachusetts: Wroods Hole (Melander).

Connecticut (Loew).

New York: Ithaca, at salt pond (Johannsen).

New Jersey: several localities (Smith Catalogue).

Illinois: Gallatin Co., at salt pond (Packard).

Utah: Box Elder Lake (salt). Garfield (brackish seepage). Promontory Point (brackish spring). 
Idaho: Market Lake (overflow from irrigating ditch).

Nevarla: Hazen (overflow from irrigating ditch). Winnemucca Lake (alkaline). WValker Lake (alkaline).

California: Mono Lake (seepage near lake).

Washington: Soap Lake, Grand Coulee (alkaline).

\section{HABITS.}

Comparing my observations of this species with those on the two preceding, a striking difference appears in the density of the water in which they live, as subopaca occurs only in the less dense waters, often in those with a specific gravity scarcely more than I. The other two, as already stated, seem not to occur except in the dense water or near it.

In Box Elder Lake, a shallow expanse of slightly salty water two miles north of Brigham, Utah, I found this species, the first Ephydra of my trip. Using a hydrometer, I attempted to find out the density preferred by the species, and here I learned my first lesson, emphasized all the way afterward-that in all these bodies of salt and alkaline water, the density is subject to great fuctuations, and the insects are able to adapt themselves to these. Along the side of the railroad grade a stream of waste irrigating water ran into the lake; it was possible to find all densities from I to I.oI9, and the larvæ of the fly, though not numerous, seemed at home everywhere, or at least to a density of I.oor. A few day's later, near Garfield, Utah, subopaca was found around waste water, sp. gr. I.oo; but it was seepage that perhaps contained too little alkaline matter to be detected by my instrument. I have recorded under distribution several cases like this, and the interesting question is still unsettled whether some small amount of salt or alkali is not a necessity in water that is to support larvæ of this species. The adults are often found at fresh water if it is near a denser supply; in the road near the Mono Lake postoffice this was especially in evidence, where there was a seepage of very pure water with plenty of subopaca adults standing on it (the adults generally stand on the water, not on the shore).

At Bodie, Cal., an old mining camp on the top of a mountain range at an elevation of 8,400 feet, there were specimens of what I took to be this species (certainly an Ephydra) standing on the surface of reddish seepage water from a manure pile. 
It is everywhere more difficult to find the larva of this species than of the two preceding; I found them only twice. This may be on account of the adults moving farther from the place of emergence than in the other species, or possibly they form more distinct broods, so that no larve are left behind, but all transform nearly together.

Packard's notice of what he called halophila contains the following quotation from his correspondent (E. T. Cox) at the Equality Salt Works:

"I send you the larva and pupa of a dipterous insect (Ephydra) found in the brine at the salt works near Equality, Gallatin Co., Ill, in such prodigious quantities as to fill up the wooden conduit pipes. These larve [puparia-Packard] are gregarious, collecting in masses and form great rope-like bunches by clinging around small fibrous roots on the sides of the little ditch that conveys the brine from the first 'Graduation or Thorn House,' to the pump at the furnace. The brine as it comes from the well has a strength equal to 7.3 Baumé, and is graduated after the German plan, by showering it successively over thorn bushes arranged on beams from top to botton of three separate frames, from forty to forty-five high, called 'Graduation or Thorn Houses.' What is remarkable in this is, that the above larva can nowhere be found except in the brine after first gradation, that is, passed over the first house, where they are found in such quantities as to prove a great muisance."

A similar case is reported to me from brine pools near the salt works at Ithaca, N. Y., by Dr. O. A. Johannsen, now of the Maine Experiment Station, who sent me specimens for identification. The larvæ in this case were found in pools of varying density, ranging from 1.5 to 6.5 grams of salt per liter of water. The noticeably greater density of the water in the case quoted by Packard is as yet unexplained; no further observations at that place have been made.

\section{Ephydra Millbrae Jones.}

Jones, Tech. Bull. Cal. Ex. Sta., Vol. I, No. 2, pp. I55-159, 1906. Adult, pupa, puparium, larva and egg described; several figs. Breeding in salt marshes on southwest side of San Francisco Bay, Cal.

This species (Fig. 6) is closely allied to subopaca, if not even identical with it. The primary difference in the adult is the darker color of the legs, the femora being dark greenish with a slight metallic 
luster, the tibire yellow with infuscated tip, the tarsi infuscated. The average of size is slightly larger, and the hairs and bristles are slightly longer, than in subopaca. The color of the pollen over the body is more greenish in millbre, yellowish in subopaca. Occasional specimens with lighter pollen and yellow legs occur in millbra, the lightest cnes corresponding exactly with the other species; just as, among the subopacas of the interior, dark-legged specimens are occasionally seen. In either case 98 per cent. or so are true to type. As I have not studied the larva and pupariun of millbre, I feel that it would be premature to assert the identity of the two species.

The puparium as figured and briefly described by Jones seems to be the same as in subopaca. His figure and description of the larva indicate a small amount of dorsal pigmentation and a larger development of the anterior spiracles, but the examination of material in both species would be needed to determine whether a specific difference exists here. The egg according to Jones is shaped like an appleseed, and has tufts of minute hairs on its surface; it is attached by its larger end to floating bits of vegetation or puparia.

\section{Distribution.}

Jones mentioned portions of San Francisco Bay, from San Mateo to San Bruno. I have collected it in the following localities:

Salt marshes of S. F. Bay adjacent to Palo Alto, in February, April, August and October.

Alum Rock park, near San Jose, Cal., 20 miles or so from the bay, April 5 .

Santa Monica, Cal., July 3I.

San Juan Island, Wash., several places, May to July.

Professor C. F. Baker sent me a specimen collected at Laguna Beach, Southern Cal.; while I am indebted to Professor Melander for specimens taken May I7 at Olga, on Orcas Island, Wash.

\section{Habits.}

The species keeps close to the seashore. The Alum Rock recorc. above is the only apparent exception, and there the park with numerous mineral springs is traversed by a stream which empties, or at one time did, into San Francisco Bay. 
Jones says: "Like mosquitoes, they seem unable to breed in water affected by the tide, but prefer the smaller pools that are practically without motion. . . I have found the flies living in ponds where the salinity was as high as 4.2 per cent., being almost one per cent. higher than that of average sea water. . . The adult flies abstract their nourishment from the surface of the water in which their larva live. They are especially fond of decaying anmal matter, and will collect in swarns on water containing dead crabs or other animal bodies."

At Santa Monica the species was abundant July II, I9II, on the surface of a pool at the mouth of Santa Monica Creek. The creek is small, and disappears in the sand as it approaches the beach. Here there was a pond some 15 feet wide and jo long, with no visible outlet or inlet, on which were the flies, but in which I could find no larvie even in prolonged search.

Explanation of Plates.

Plate I.

Fig. I. Ephydra gracilis Pack., adult,$+ \times 8$.

Fig. 2. Ephydra gracilis Pack, nearly full-grown larvæ, $\times 4 \frac{1}{2}$.

Fig. 3. Ephydra gracilis Pack., cluster of puparia hanging together by anal tubes, $\times 3$.

Fig. 4. Ephydra gracilis Pacis., mass of dried puparia from Great Salt Lake beach, slightly reduced.

Fig. 5. Ephydra subopaca Loew, adult $9, \times 8$.

Fig. 6. Ephydra millbra Jones, adult + , $\times 8$.

Fig. 7. Ephydra hians Say, dorsal anterior dehiscent portion of puparium, enlarged (see Fig. I6, arrow).

Plate II.

Fig. 8. Looking east from Promontory Point, Utah, along the S. P. cutoff. The dark material collected in the bay in the foreground is Ephydra gracilis puparia.

Fig. 9. Looking west on the south side of the railroad near Fig. 8. The puparia of gracilis form the dark deposit along the edge of the water.

Fig. Io. Ephydra gracilis on railroad rails at Lakeside, Utah; the near rail on the right is focused best.

Plate III,

Fig. 11. Ephydra hians Say, eggs, $\times 40$.

Fig. 12. Ephydra hians Say, young larva, $\times 24$. 

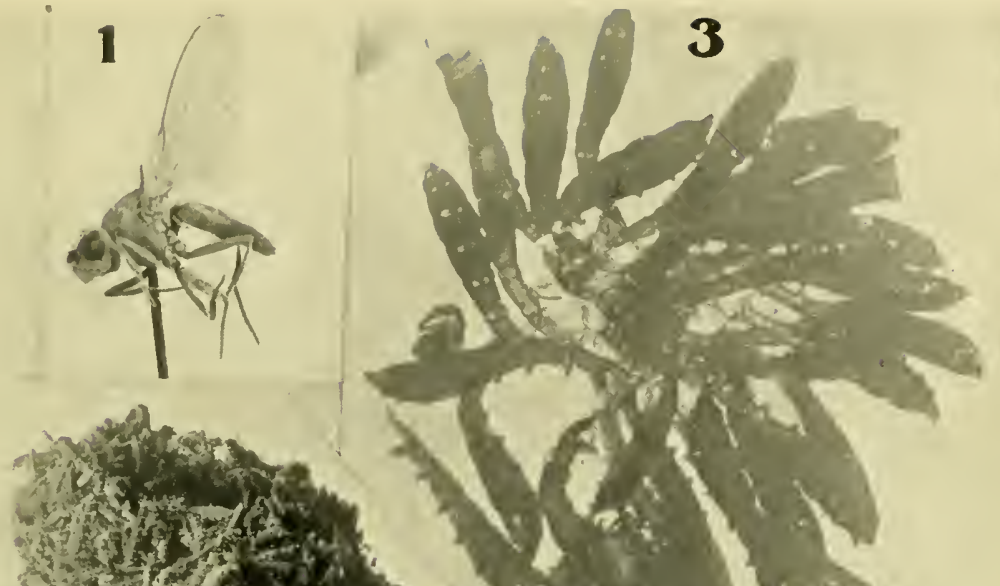

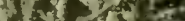

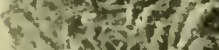

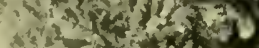

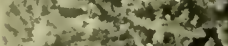

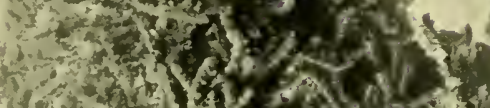

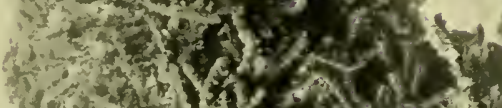

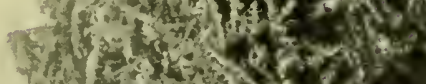

\section{0}

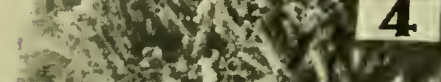

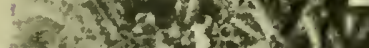

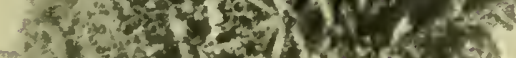

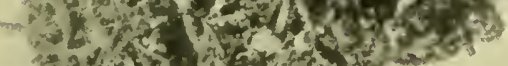

asy

430 .

$20+1+160 \times 3=$

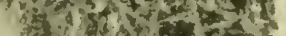

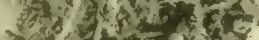

340, of

1.

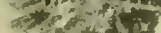
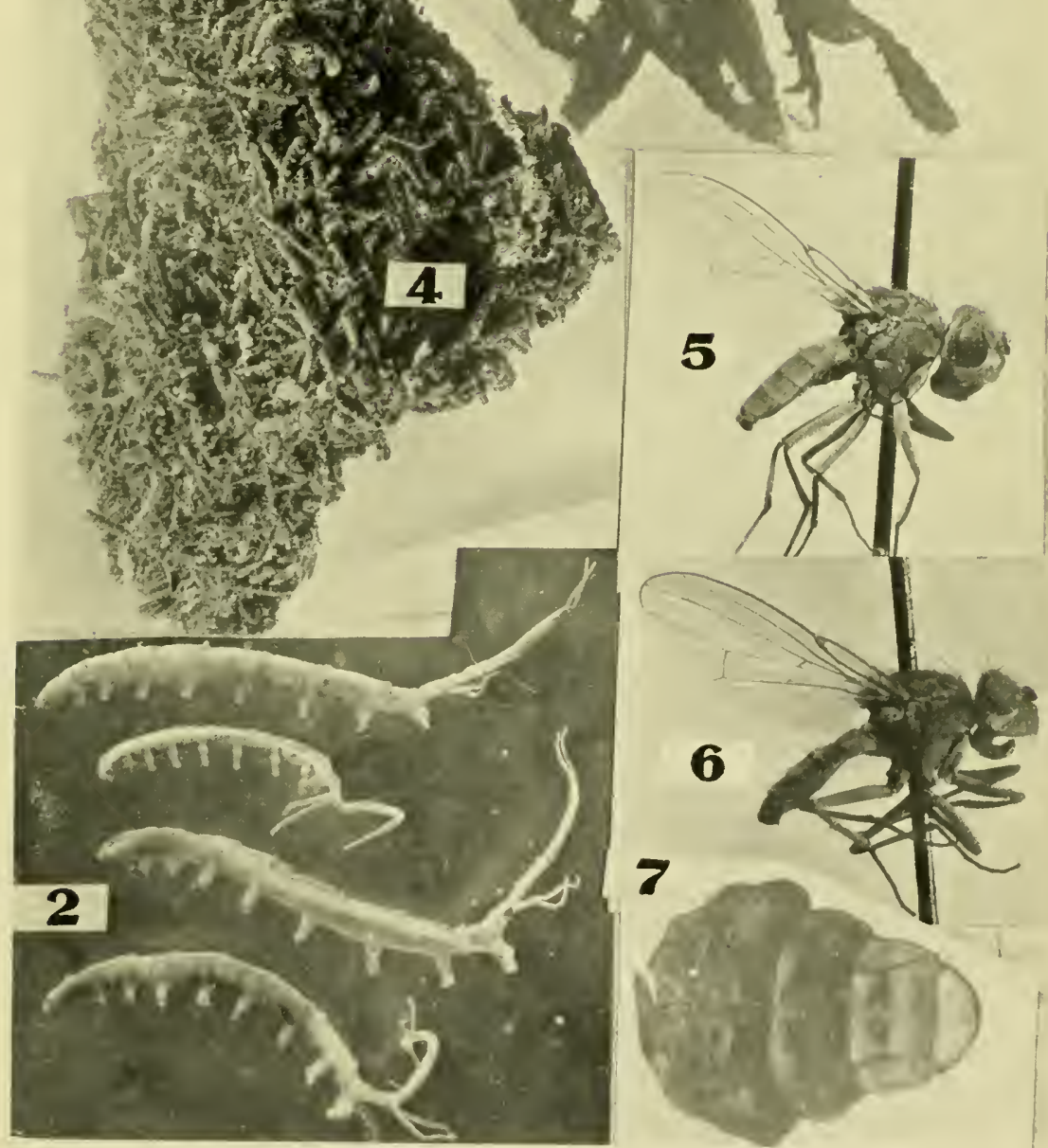

Western Ephydra. 



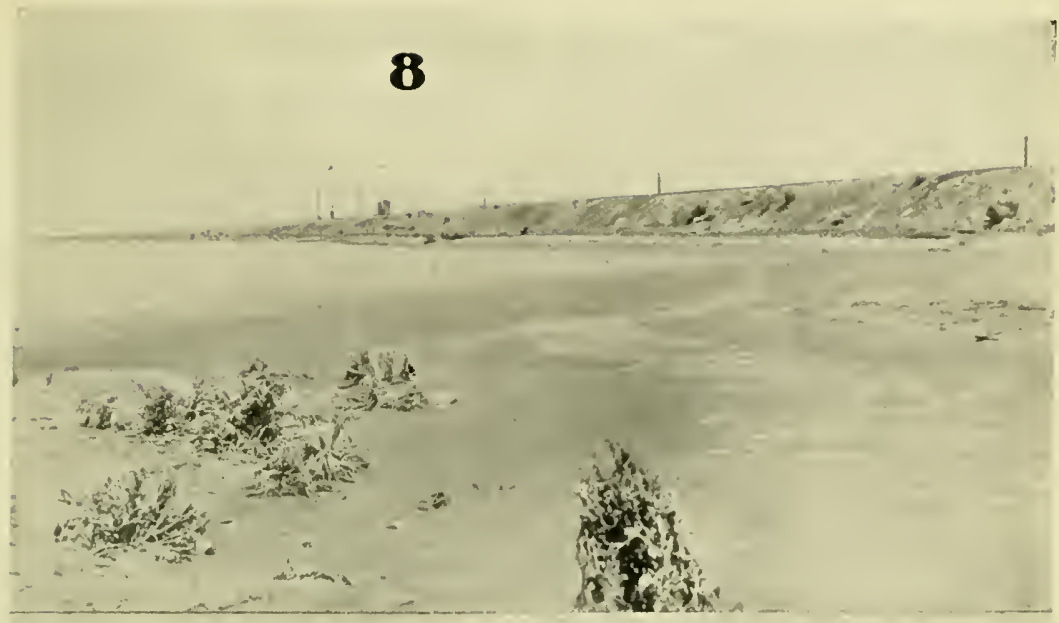

\section{9}

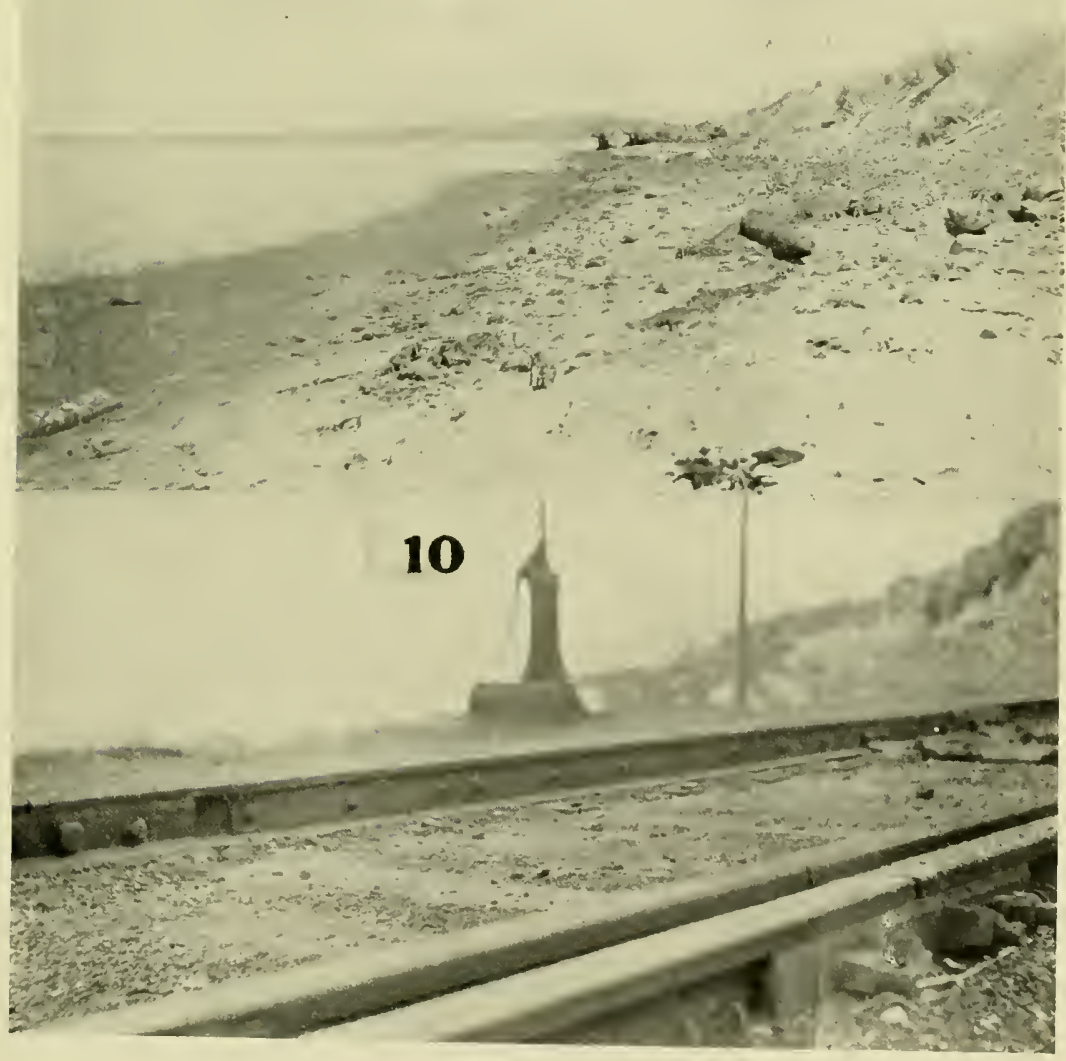

Western Ephydra. 



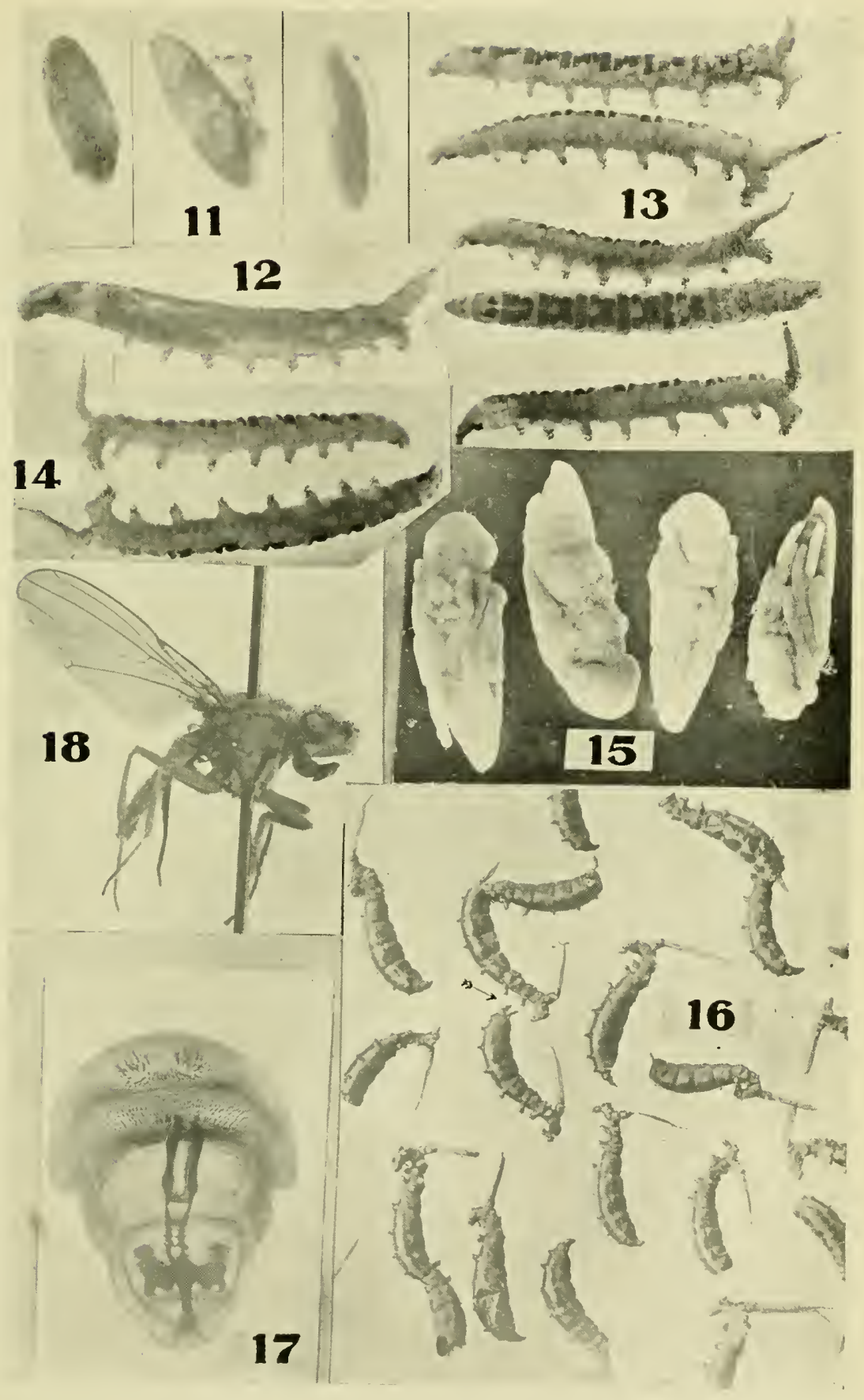

Western Ephydra. 

June, 1912.] Aldrich : Two Western Species of Ephydra.

Figs. 13, 14. Ephydra hians Say, full-grown larve, $\times 4$.

Fig. 15. Ephydra hians Say, pupæ, $\times 7$.

Fig. 16. Ephydra hians Say, puparia, $\times 3$.

Fig. 17. Ephydra hians Say, ventral anterior dehiscent portion of puparium, containing the larval mouthparts (see arrow, Fig. 16).

Fig. 18. Ephydra hians Say, adult $+\times 8$. 


\title{
TWO WESTERN SPECIES OF EPHYDRA.
}

\author{
By J. M. Aldrich, \\ Moscow, Idaho.
}

As a completion of the preceding article I append the description of a new species of Ephydra that I know only in the adult stage, which was collected while investigating the shores of Great Salt Lake last summer, together with a redescription of E. viridis Hine. Both species are strongly marked and easily recognizable. There is also added a table for the separation of the western species. The only name occurring in it besides these two new species and the four mentioned and described in the preceding paper is atrovircns Liv., which I have collected in the vicinity of Moscow, Idaho.

\section{Ephydra auripes new species.}

Male.-Opaque green, the front except orbits and ocellar triangle, and the posterior half of the mesonotum with the scutellum, intensely shining bluegreen or bronze-green; legs dark green, all the tarsi wholly golden yellow.

Ocellar triangle and wide frontal orbits velvet-black, rest of front intensely shining blue-green, three fronto-orbital bristles curving over the eye, besides the outer vertical bristle which does the same; antennæ small, black, second joint robust, third small, arista with only slight and faint plumosity, prominence of face very high, long and vertical in front, with a nearly bare spot above the prominence and just below the antennæ, which is sub-shining blue, the rest of the face whitish pollinose, hairy, with small bristles along the mouth and a slight row of bristly hairs across the upper part. Proboscis and palpi blackish-green.

Thorax semi-opaque greenish, changing to brilliant bronze-green behind; at the sides the change comes suddenly at the suture, on the disk gradually and farther back; scutellum also brilliant bronze-green. Chætotaxy of thorax normal, the bristles well developed. Pleuræ opaque, one rather strong bristle in the row of bristly hairs on the hind edge of the mesopleura; one sternopleural; knob of halteres bright yellow. 
Abdomen sub-shining metallic blue, fifth segment nearly a half longer than the fourth, hypopygium very small and retracted.

Legs opaque greenish-black, knees hardly yellowish, tarsi strongly contrasting deep yellow, only the tip of the last joint a little infuscated; claws black, long and straight.

Wings of ordinary appearance, veins rather pure yellow near base.

Length $3.6 \mathrm{~mm}$.; of wing $3.5 \mathrm{~mm}$.

A single made, Garfield, Utah, July 9, I9I. The specimen was not recognized as different from subopaca until after the work of the day was finished, and I am unable to state just where I got it. I collected along brackish water from Smelter station west and north to the shore of Great Salt Lake, and captured the specimen in that small region.

The species has so many good marks of distinction that it will be recognized without difficulty.

\section{Ephydra viridis Hine.}

Cania virida Hine, Ohio Naturalist, IV, 65.

A large, robust, dull-green species with yellow knees, a deep depression in the front just anterior to the oceller triangle, and ornamented hind tarsi in the male.

Male.-Front shining dark green except the wide orbits and the ocellar triangle, which are seal-brown pollinose; a deep depression just in front of the foremost ocellus; a few minute hairs on the shining portion of the front, and on the lower corners one pair of bristles, curved toward each other; the frontal orbits bear two pairs of $f$. o. bristles bending outward over the eyes, and a few hairs extending down to the face. Antennæ black, third joint large, arista with distinct, short plumosity. Face moderately prominent, convex in profile, covercd with brown pollen; the antennæ are wide apart, and the space below them is only a little less pollinose; hairs of face coarse, with a row of little bristles across above and another along the oral opening. Sides of face, cheeks and back of head with brown pollen; below the eye a bare space extends to the mouth, and behind this is a large bristle on the edge of the mouth, behind which the beard begins.

Thorax dark shining green, with a little thin brown pollen; hairs rather small, bristles strong, chætotaxy normal except that there is no post-humeral (interhumeral); pleuræ with a little more pollen, which becomes olivaceous on the sternopleura; one large bristle and a few small ones on the posterior edge of mesopleura; calypter moderately large, yellow and with brownish yellow hairs; halteres yellow.

Abdomen green, sub-shining, fifth segment nearly a half longer than fourth, hypopygium very small and inconspicuous.

Fenora and tibiæ all sub-shining greenish-black, the knees decidedly yellow, trochanters sometimes a little yellow; front and middle tarsi of plain 
structure, more or less yellow at base; hind femora incrassated, with long hairs below near base, their tibix noticeably curved, long-hairy on the inner side toward the end, shining black on the apical half of the hind and inner side; hind tarsi short, with the usual brush of yellow hairs below on three joints and a few long hairs above, directed mesially: fourth joint a little longer than the third, with a process toward the apex on the inner side, which bears a conspicuous tuft of black hair; fifth joint normal.

Wing brownish, veins brownish-yellow at base, costa a little spiny, hind crossvein somewhat oblique and bicurved.

Length $6.2 \mathrm{~mm}$.; of wing $5.6 \mathrm{~mm}$.

Female.-Greatly resembling the male in all points but the hind femora scarcely thickened, the hind tibix nearly straight, the hind tarsi a little longer than in the $\delta$, plain, with only three or four bristles above. Length $6.5 \mathrm{~mm}$.; of wing $5.6 \mathrm{~mm}$.

Five males and one female, collected on the salt marshes of San Francisco Bay, Cal., adjacent to Palo Alto, April 20 and 26, 1906. I searched in vain for additional material in August, I9I I. Nothing is known about the life listory.

This species was originally described from Brownsville, Texas. The generic reference might be argued either way, as the claws are not very straight, and very minute pulvilli are present. Hine's description is neager, and I did not suspect the identity of my material until I learned from E. T. Cresson, Jr., to whom I sent part of it, that he had compared it with the types of riridis and found them identical. I have therefore given a fuller description of the species.

\section{TABLE OF Species.}

The described species of Ephydra from the region of the Rocky Mountains and westward may be tabulated as follows:

1. With 6 dorsocentrals; a large gray opaque species, front hairy and with sereral bristles inclined mesially on the lower part.......hians Say.

With 5 dorsocentrals; front with I pair of small bristles below, inside the orbitals, or with none $\ldots \ldots \ldots \ldots \ldots \ldots \ldots \ldots \ldots \ldots \ldots \ldots \ldots \ldots \ldots \ldots \ldots \ldots \ldots \ldots$

2. Frontal orbits shining; $3 \mathrm{~d}$ joint of antenna with a long erect hair on

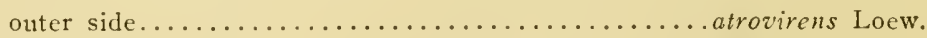

Frontal orbits pollinose; 3 d joint of antenna without such a hair .... 3

3. Tarsi bright yellow, contrasting with the black-green femora and tibiæ.

auripes Aldrich.

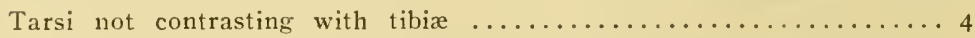

4. Very large bronze-green species with yellow knees; $\delta$ with a conspicuous tuft of hairs on inner side of 4 th joint of the hind tarsus. viridis Hine.

Not as described; $\delta$ not ornamented $\ldots \ldots \ldots \ldots \ldots \ldots \ldots \ldots \ldots \ldots \ldots$ 
5. Very small opaque gray species with shining front; the hind crossvein rectangular to the costa ..................... gracilis Packard. The hind crossvein oblique to the costa $\ldots \ldots \ldots \ldots \ldots \ldots \ldots . \ldots . \ldots . \ldots$ 6. Femora yellow (in western specimens alnost always); inland species. subopaca Loew. Femora blackish; occurs only adjacent to tide-water of the Pacific.

millbrae Jones. 

[Reprinted from Journal of the Neiv York Entomological. Society, Vol XX., No. 1, March, 1912.]

\title{
LARVA OF A SATURNIID MOTH USED AS FOOD BY CALIFORNIA INDIANS. ${ }^{1}$
}

\author{
By J. M. Aldrich, \\ Moscow, IDaho.
}

(With Plate I.)

In July, I9II, when I spent a few days at Mono Lake, California, investigating the insects of the lake especially, It was told of a "worm" used as food by the Pai-Ute Indians of the vicinity. No opportunity for getting material came until the morning of my departure. While I was at the Mono Lake post-office awaiting the departure of my stage, the postmaster, Mr. John Mattley, an old Swiss pioneer of the basin who had taken a very intelligent interest in my work, asked me, "Have you seen the worms the Indians eat?" I replied that I had not, but very much wished to do so. Up to this time my information had led me to suppose the insects were larvæ of borers in the trunks of trees. He had two Indian women working in his hay-field, both of them at the time standing about in the road by the residence. "Cone with me," he exclaimed, and approached one of the women, asking her the question, "Have you got any of those worms on hand?" The woman grinned rather sheepishly, as if expecting the subject to be a matter of ridicule, and said, "No, all gone." " But you had a lot yesterday," persisted Mr. Mattley. "All gone," was all she would reply, so Mr. Mattley took me along to the other woman. She began with the same reply, but finally admitted that there were some of the cooked ones still on hand. "Show them to us," demanded Mr. Mattley, and she led us to her camp near by, where she laid back an old cloth and disclosed a much-smoked threequart tin bucket, nearly full of a yellowish, greasy-looking stew.

${ }^{3}$ An incidental result of an investigation of the insects of western salt and alkaline lakes, carried on with the aid of an appropriation from the Elizabeth Thompson Science Fund. 
Considerably excited by the prospect, I picked up a little stick and began to fish in the stew. It was half full of large caterpillars, blackened by drying, resembling dried and stewed prunes as much as anything. One of them I pulled in two and thrust a half in my mouth to see what sort of food it was. I found it tough and almost flavorless, with an insipidity beyond expectation on account of the absence of salt in the stew. The fat had cooked out so as to float on the fluid, and had a strong odor like linseed oil, which was in fact the only quality beyond toughness that I noticed. After I had performed the cxpcrimcntum crucis, my hostess, if I may use the term, appeared to be relieved of the fear of ridicule, and brought out a cloth in which she had about a quart of the dried worms, uncooked. These I bought of her and brought home with me. As the stage departed about this time, I secured no farther information from her about the mode of preparing this food material. The description given me by $\mathrm{Mr}$. Mattley and also by Mr. Rector of the general store near by, was to this effect: The caterpillars feed on the leaves of the yellow pine (Pinus ponderosa) but not on the one-leafed piñon (Pinus monophylla) which is much more abundant about Mono Lake. The Indians collect the caterpillars by making a smudge under the tree, for which purpose they make a trench rather close about the base of the tree; this is presumably to guard against the spread of the fire. As the thick smoke rises and envelopes the caterpillars, it causes them to let go and drop to the ground, where they are collected by the Indians, killed and dried. The preserved material is called Papaia.

A few days later, while I was at Berkeley, Cal., I had a conversation on this subject with Mr. Roy Headley, of the Forest Service in the San Francisco office. He informed me that while inspecting a national forest some distance southeast of the Mono Lake basin, he found every pine over a considerable hillside surrounded by a trench in which there had been a fire; he examined the work with interest, for fear that the forest was being subjected to an undesirable fire risk. It appeared from his statement and what I learned at Mono Lake that the collection of this caterpillar for food is an industry of considerable importance in the territory along the Nevada-California line.

Observing that the stewed specimens, of which I had fortunately saved a couple, were much fresher in appearance than the dry ones, I 
tried to freshen up some more material by prolonged soaking in warm water. To a certain degree it improved the condition of the specimens, but was far from making them life-like. I then tried injecting the softened specimens with gelatine, which helped a little more. The skins had too many holes in them, after manipulating them to make them soft, to hold the gelatine very well, so I tried injecting with dental plaster of Paris, and with this I obtained some specimens that were as plump as life, if not more so, and certainly a good deal solider. Some of these injected specimens, as well as of the shriveled dried ones, are illustrated in the accompanying half-tones.

The identity of the insect concerned remains to be considered. I was surprised to learn that no species is known to have the habits I have described. Material sent to the Bureau of Entomology elicited the following statement from Dr. Howard: "Dr. Dyar has examined the caterpillars eaten by the Indians at Mono Lake, and decided that they are Saturnians, probably of the genus Hemilcuca, but he does not know any species feeding on pine or one so common as this must be. He suggests that perhaps it is some 'rare' species whose habits are unknown."

I append a description of a moderately distended injected larva.

Length, $70 \mathrm{~mm}$. Head acorn-colored, $6.3 \mathrm{~mm}$. wide, $5.7 \mathrm{~mm}$. high. Width of widest body-segment (2d abdominal) II.I mm. Color as revived yellow mottled with paler and blackish; all the body-segments except the first and the last two crossed by a broad yellow band on its posterior part, which becomes indistinct along the sides about the vicinity of the spiracles. A central dorsal whitish stripe crosses all these bands, and its color interrupts the yellow to some extent, especially along the middle of the length. On each side of the median pale stripe is a wide, blackish stripe, interrupted by the yellow crossbands; laterad to this is a narrow pale stripe, also interrupted. The side below this is mottled yellow and blackish, with an undulating yellow stripe below the spiracles. Ventral side yellow, prolegs, anal plate and anal prolegs acorn-colored.

The tubercles are all small, black, and so much broken off that I can only make them out by piecing together several specimens. They appear to have the following arrangement: four dorsal in a transverse series across the middle of each segment, for ten body-segments; the eleventh segment with a larger median branched tubercle (shown in 
profile in half-tone), and only one lateral each side; the twelfth segment with a similar median tubercle arising near the hind edge, and two pairs of lateral ones. Below the line of spiracles there appear to be two small tubercles on each segment, but they become very small and indistinct on the last three segments.

\section{Explanation of Plate I.}

All about natural size.

No. I. Two larve injected with plaster of Paris.

No. 2. Four specimens partly injected with gelatin.

No. 3. Several of the dried specimens as obtained from Indian woman. 

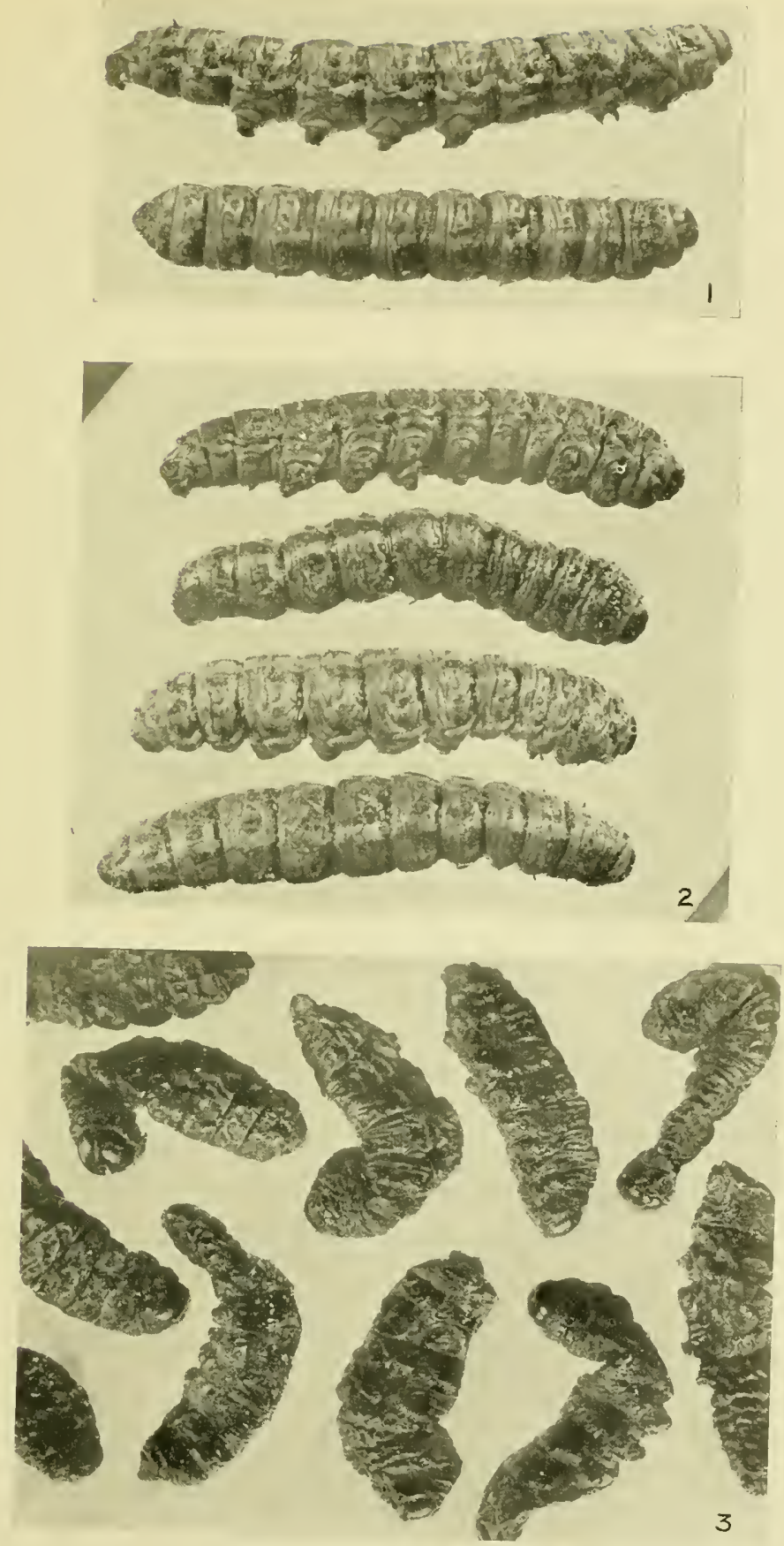

Edible Caterpillars 



\title{
Baron Osten Sacken.
}

\author{
By J. M. AldDrich.
}

(Plate X1)

Karl Robert Romanovich, Baron von der Osten Sacken, commonly known among entomologists as C. R. Osten Sacken, was born in St. Petersburg, August 21, 1828, and died at his home in Heidelberg, Germany, on May 20, I 906.

In 849 young Osten Sacken entered the service of the Russian Imperial Foreign Office. After some years of apprenticeship in diplomacy, he was in 1856 appointed Secretary of Legation in Washington. In 1862 he was made Consul General for Russia in New York City, and held the position until i 87 I, when he retired from the diplomatic service. After several journeys to Europe and back, he again settled in the United States, this time as a private citizen, and remained until r877; in this year he returned to Europe, making his home in Heidelberg the remainder of his life.

From 1856 to 1877 , it will be seen, Osten Sacken was almost continuously a resident of the United States. Before this he had begu11 to work on Diptera, especially Tipulidæ. Inme-

We have received two interesting accounts of the life of Baron Osten Sacken, who may almost be called an American entomologist. These are by two eminent dipterists, and, not caring to discriminate, we deciderl to publish hoth.-EDs. 
diately on getting settled in this country he began to organize things for extensive dipterological research. He published (in I859) a catalogue of the described North American Diptera; he collected a large amount of material in the order; he made the acquaintance of most of the collectors in various parts of the country, and had them send him their Diptera; most of his accumulations he sent to Loew in Guben, Prussia, for description, reserving only a few families, principally the Tipulidæ and Tabanidæ, for himself; he also established relations with the Smithsonian Institution which resulted in the publication of a large part of the descriptive matter prepared by Loew and himself in the four volumes called by the general title of "Monographs of North American Diptera" ; in short, it may be said that for some twenty-one years nearly all the work done on the order was directly due to the tremendous energy of Osten Sacken. Toward the close of the period, after visiting the principal type collections of Diptera in Europe, he published a second catalogue of North American Diptera, this time critical in character and exhibiting the actual status of the order in a manner which for clearness, completeness, and absolute mastery of the subject must forever remain an unapproachable model for later workers in the order. Osten Sacken had practically created himself all the main subject matter of the catalogue; hence the impossibility of any later entomologist ever occupying a similar position with regard to it.

In addition to the Smithsonian monographs and his two catalogues, Osten Sacken's Prodrome to a Monograph of North American Tabanidæ, published by the Boston Society of Natural History, and Loew's Centuries of North American Diptera (one thousand new species, published in Germany), enibody the principal results of his labors.

As a fitting climax to his achievements, Osten Sacken successfully conducted a rather difficult and delicate negotiation, by which Loew was reimbursed for his labors on the North American material, and surrendered it all to the Museum of Comparative Zoology at Harvard, at that time much the best depository in the United States for such material. Osten 
EN'. NEWS, VoL. IVII.

Pl. XI.

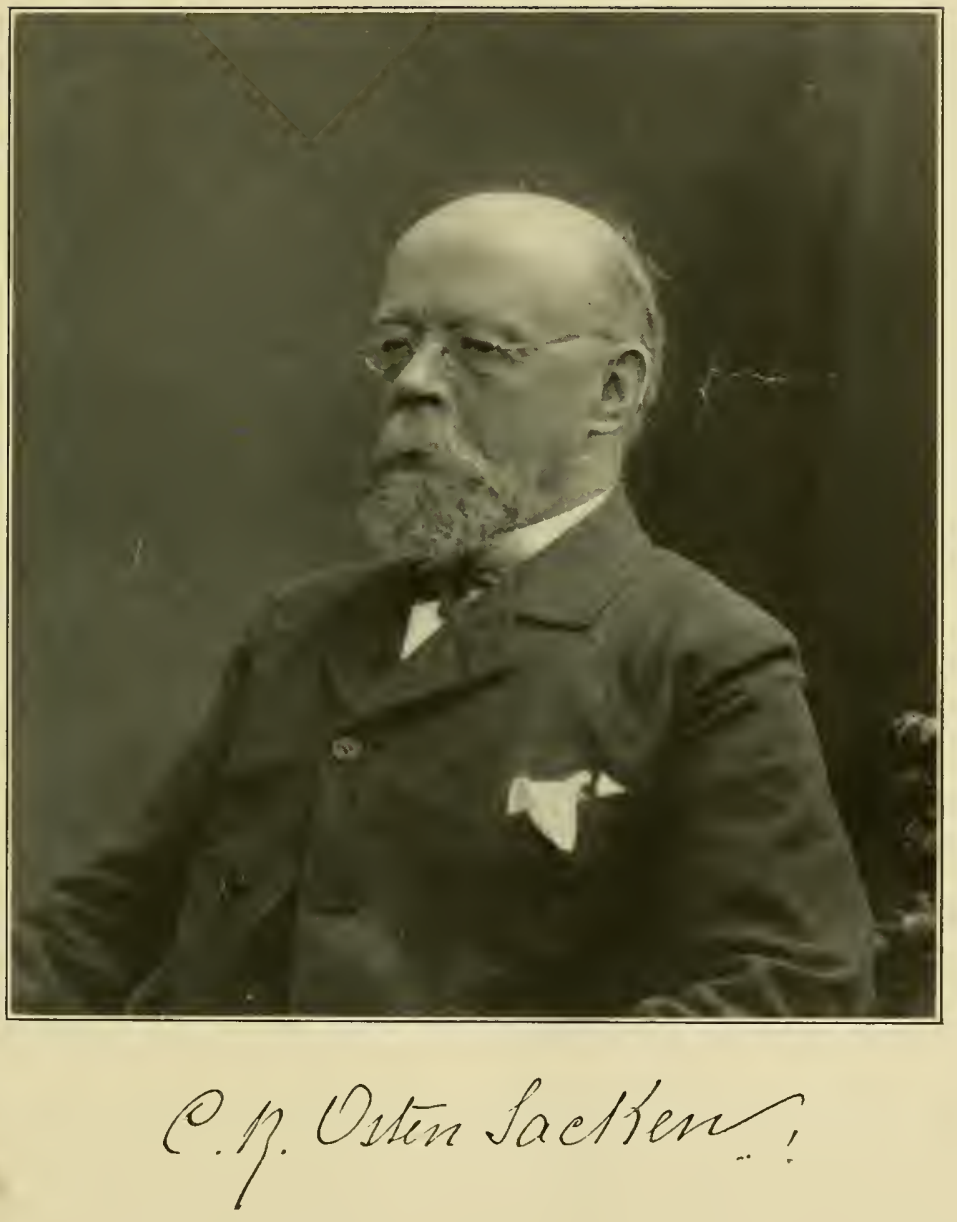



Sacken donated all his own material to the same institution, and the Loew-Osten Sacken type collection of Diptera was thus established; it still remains in good condition, and we may expect will continue to be useful for many years to come.

After returning to Europe, Osten Sacken felt that his labors in descriptive entomology were practically at an end. $\mathrm{He}$ continued to publish papers on the larger phases of classification, on insect habits, historical researches on entomology, etc., up to a few years before his death. In $1886-87$ he published 216 pages of Vol. I. of the Diptera in the Biologia CentraliAmericana. In 1903 and 1904 he published his "Record of My Life Work in Entomology" (parts I and II printed in Cambridge, Mass.; part III in Heidelberg), which gives not only a review of his own activity, but includes critical estimates of several contemporary entomologists, and much historical matter on dipterology in general.

Osten Sacken's entomological work was almost completed tiventy-eight years ago, hence he seems to belong to a generation that has long passed away. Only one living dipterist of this country, so far as I know, had a personal acquaintance with him-I allude to S. W. Williston, who met him on his last trip to this country.

Osten Sacken wrote in Russian, German, French, Italian, English, and on occasion in Latin; he preferred English, in which he had a literary style distinguished for clearness, force and accuracy. The striking qualities of his character were energy, farsightedness, persistence, keen discrimination, and conscientiousness. No pecuniary consideration ever lessened the completeness of his devotion to the Diptera. He always sought to be impartial, but the bent of his mind was such that he could never appreciate the argument of a man who disagreed with him. Such people seemed to him either mildly insane, or else animated with a personal animosity towards himself. In a letter to the writer, he says in regard to Loew, "I am conscious of having been perfectly fair towards him in my Record. I never doubted for an instant that he was a perfectly honest and veracious man. His idiosyncrasies I incline to ascribe to a congenital defect of the brain which 
disturbed its normal function and finally culminated in the brain disease to which he succumbed. Every one of us, very probably, is afflicted with some malformation of this kind which more or less impairs his mental vision." May we be as charitable witl Osten Sacken in regard to the two or three animosities which he especially cherished.

As a correspondent, he was delightful. During his American residence he accumulated large numbers of letters from entomologists in various parts of the country, which it seems from his Record he faithfully preserved till his death. This material would be of great value if ultimately acquired by some American institution; the history of American entomology during the ' 50 's, '6o's and ' 70 's is largely embalmed therein.

Two years ago he wrote, "As the Grandfather of American Dipterology, I an very much interested in the progress of my descendants."

On another occasion, "At my age a man does well, when he is able to do so, to withdraw from his usual occupation or profession, and to leave the field for a younger generation. For about fifty years I have worked hard in my science and have reason to be content with the result. My Record I hope to have published bye and bye, and shall allow myself from time to time to publish "obiter dicta" on dipterology, like the short articles which have appeared in the Ent. M. M., London, recently. But, with these exceptions, I give up entonology, and shall not take any part in discussions. In many points my opinions are peculiar. I have explained them distinctly enough in my writings, and posterity will pronounce upon them. For this reason I do not enter into any further discussion about $* * *$, the result of which is, for me, of sovereign indifference."

And yet again, "My health is excellent, but my brain is easily tired and my working power has much diminished. I am in the position of a traveler at a railway station, waiting for a train to depart with. This departure I expect without the slightest apprehension."

He was a man, take him for all in all, I shall not look upon his like again. 


\title{
The Dipterous Grnus Calotarsa, with one new Species.
}

\author{
By J. M. AldRICH.
}

(Plate IV)

The discovery of a new species of this charming little group makes it worth while to give a brief review of the genus.

Townsend, in I 894 (Canadian Entomologist, XXVI, 50-52, figs.), described the genus and its typical species, Calotarsa ornatipes, from a single male specimen collected at Chanpaign, I11. He referred the genus to the family Syrphidae, in which he acknowledged that it would occupy a very anomalous position. The error of overlooking the family Platypezidae was corrected by Banks in the next number of the journal (p. 88); he expressed the opinion that Calotarsa was a synonym of Platypeza, and reported another male specimen in his collection, taken at Ithaca, N. Y. In the following number of the journal, Townsend admitted the relationship of the genus to the Platypezidae, but contended that it was not synonymous with Platypera (p. IO2). Williston in the same number (p. I I6) mentioned the genus as probably synonymous with Platypeza.

Late in 1894 , W. A. Snow published in the Kansas University Quarterly (III, 143-152, I pl.), a revision of the North American Platypezidae, with several new species; a supplement to the paper was added in the same publication in January, I895 (III, 205-207). He did not accept Calotarsa, referring ornatipes to Platypeza; he described another species with greatly ornamented hind feet, under the name of Platypeza calceata. Of this he had seventy-five males and one female, collected in Hop Canyon, Magdalena Mts., N. M., on August 19-2I, IS94. He also reported another specimen of ornatipes, sent him by me, and collected by me on a window at Brookings, S. D. No other species with ormamented hind tarsi have been known up to the present, nor have aly other specimens of the two described species come to light, as far as I know.

In my catalogue of North American Diptera, I recognized Calotarsa as a distinct genus, mentioning that I did so on Mr. Kahl's recommendation. 
The question whether it is really synonymous with Platypeza I am unable to settle at present, not having access to material in typical Platypesa. Snow declared that a somewhat larger size and the ornamentation of the hind tarsi of the male were the only characters to separate the two genera, and he thought them insufficient. The typical Platypezas figured by Snow slow in the male the hind tarsus but little modified-less than in the female-nothing at all of the surprising structures shown in his figures of ornatipes and calceata, which I reproduce on my plate. The question of synonymy I leave in abeyance, rather hoping that further examination of abundant material may show characters applicable to both sexes; at least we have subgeneric characters in the feet of the male.

The two species previously known and the one herein described will be readily separated by the * characters of the hind tarsi of the males, as shown in the plate. I will only add in this connection that otherwise the three species are exceedingly close together, insignis being more uniformly yellow on the abdomen than the other two. The female of ornatipes is as yet unknown, while of the other two insignis has a wholly pure yellow abdomen, differing slightly from calceata. The three species form a very compact group, whether of generic or subgeneric rank.

In regard to the habits of the adults and the function of the tarsal ornaments, little has been observed. In omatipes, only three specimens are known, one of which was collected on a window-obviously an accidental occurrence. Of insignis, the type male was collected hovering in the air in half-shady open woods, about four feet above the ground; the females were all collected in rather open woods, hovering in the air, most of them over a wet spot in a shady road, which no doubt attracted them, as the weather at the time was intensely dry. It was about four in the afternoon, and no males were flying at the time. Snow noted a few interesting points about the habits of calceata. The flies were "dodging and soaring in the air

* Secondary sexual characters are very constant in Diotera, whatever may be the case in other animals. 1 remember hearing Dr. Joln B. Smith say that he found the same constancy in Lepidoptera. I have long believed that Darwin over-estimated the variability of these characters in general. 
in assemblages of, say, a dozeri individuals. None were caught outside an area of about an acre." "In flight these insects allow their hind feet to hang heavily downward, and look as if they were carrying a burden." His single female was one of a pair that were copulating on the wing.

These enlarged feet naturally suggest those of Dolichopus, a genus of flies somewhat distant from this, in which the males parade their tarsal ormaments assidnously before the females. When the front tarsi are ornamented, the insect stands on the ground to display them, but a case is known in which the middle tarsi are the beautiful ones, and the male of this species hovers over the sitting female so that the tarsi liang before her. In Calotarsa it is not unlikely that both sexes are on the wing while these exhibitions occur, hence it may be very difficult to make close observations of them.

Before passing to the general description of the new species, I will describe the hind tarsi of the male, as they are extremely interesting and remarkable.

All the first four joints are compressed, and on the inner surface have a fine brush of close appressed yellow bifurcated hairs, which is best developed on the second and third segn11ents. These joints are all provided with a vertical groove at the distal end, enclosing the proximal part of the succeeding joint; hence the second and third appendages appear in side view as if they arose between two segments. The outer side of the first and second joints has numerous stiff lıairs, which end in very slight knobs.

The first joint has on the upper side near the base a slender, long process, ending in an oval disk; its basal part is somewhat thickened, and has a few of the blunt hairs before mentioned.

The second joint has a similar organ arising in a corresponding position; in this case the process is smaller, and at the base is compressed and transparent.

The third joint has attached to its upper surface, from the base nearly to the apex, a very thin membrane-like expansion, which is of a bright silvery color, and bears a peculiar jetblack pattern. It lias somewhat the appearance of a flag, and 
suggested the specific name (insignis, distinguished by a mark).

The fourth has a large, comparatively thick expasion upward and ontward, which is black in color, and is set off from the body of the joint by a white or somewhat silvery crescent.

The fifth joint is not at all compressed, and has in fact a perfectly normal structure, rather depressed.

The figure shows the "flag" lapped over a little on the enlarged fourth joint.

Calotarsa insignis n. sp.

Male.-Length, $6.5 \mathrm{~mm}$. Head and thorax black, cinereous; proboscis, legs and abdomen yellow. Eyes contiguous for a considerable distance on the front, ocellar tubercle prominent, with a few small brown hairs; face black, cinereous, concave and receding below; antennae yellow, short, the third joint, except its base, infuscated, the three joints of successively increasing length; arista apical bare, slender; proboscis retracted, short, yellow, palpi very small, yellow; occiput black, rather flat, almost bare. Thorax black, cinereous, especially on the sides; four faint brown lines on the dorsum, the two inner ones close together, abbreviated behind, the two outer ones abbreviated In front; on the side of the dorsum, before the transverse suture, are three small bristles; before the scutellum, at each side, are three or four very small ones; on the margin of the scutellum are five pairs of larger ones, with a considerable median interval; the scutellum yellowish, except on the disk; humeri a little yellowish; halteres yellow, the large, crumpled knob a little infuscated; squamae yellow, with delicate yellow cilia ; metanotum black. Abdomen yellow, all the incisures, except the first, narrowly blackish (the first slightly blackish at the sides); hypopygium exserted, rounded, rolled up under the fifth segment; on the hypopygium and along the sides of the abdomen are fine, erect hairs, longer, more bushy, and yellow anteriorly; behind they are brown. Fore and middle legs, including coxae and tarsi yellow, the femora moderately infuscated above, and with a stripe of black hairs on the front ; the tibiae gradually and moderately infuscated from near the base; hind tarsi as figured and above described. Wings subhyaline, slightly infuscated toward the apex; the space between auxiliary and first longitudinal cells yellow; third vein ending exactly in the apex; fourth vein forked, the posterior branch ending half way between point of furcation and the margin ; hind cross-vein hardly more than half its length from the margin.

Female.-Length, $4.8 \mathrm{~mm}$. Front rather wide, narrowing slightly below, opaque dark brown in color, near the antennae cinereous, with a median depression; proboscis and palpi larger, antennae smaller than the male. The brown lines of the thorax are more distinct. The pos- 


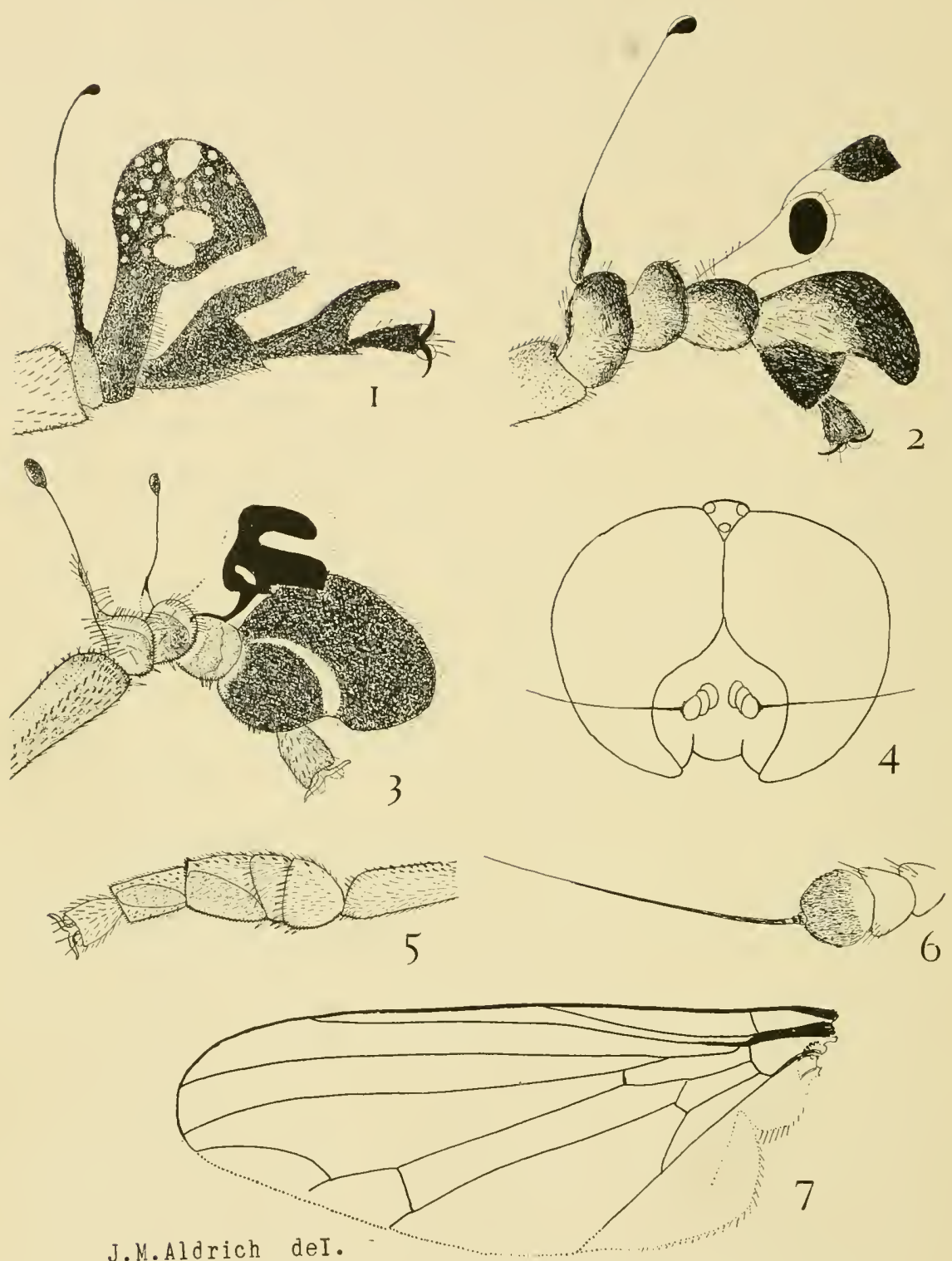

J.M.Aldrich deI.

THE DIPTEROUS GENUS CALOTARSA. 
terior part of the thorax, with only two bristles on each side; scutellum with three pairs of bristles. Abdomen yellow, scarcely infuscated at all. Legs wholly yellow, except the tarsi, which are somewhat infuscated toward the end ; they are compressed and enlarged as shown in figure. Venation as figured; the posterior branch of the fourth vein comes nearer the margin than in the male, but does not reach it.

Material examined: The type is a male, captured October 21,1905 , in the foothills about six miles west of Stanford University. There is another male (cotype) in the collection of the entomological department of Stanford University, collected in the vicinity October 7 , I900. Nine females, all collected by myself in the same vicinity as the first-mentioned male, on October 21 and 28, 1905. Two of these cotype females will be deposited in the collection of the entomological department of Stanford University. The type and the other females will remain for the present in my own collection.

\section{EXPLANATION OF PLATE IV.}

I. Hind tarsus of Calotarsa calceata, male, enlarged (after Snow).

2. Hind tarsus of $C$. ornatipes, male, enlarged (after Snow).

3. Hind tarsus of C. insignis n. sp., male, outer side $\mathrm{x} 20$.

4. Head of C. insignis, male, front view, $x 20$.

5. Hind tarsus of C. insignis, female, outer side, $x 25$.

6. Antenna of $C$. insignis, male, inner side, $\mathrm{x} 40$.

7. Wing of $C$. insignis, female, $\times 15$. 

Rusticus acmon, Boisd.-Abundant in spring and fall. The larva feeds on Hosackia. This species is much given to variation, and I think good series from various localities would show that a number of so-called species are but forms of this.

Cyaniris ladon, Cramer, var. piasus, Boisd.-This is one of the earliest and commonest butterflies in California, where it replaces the Atlantic ladon (pseudargiolus, Boisd. and Lec.). The caterpillar feeds on the flowers of the California Buckeye (Esculus californicus). Feb. to July.

Everes amyntula, Boisd.-Common in May and June. Frequents the flowers of Esculus, which is most probably the food-plant.

Brephidium exilis, Boisd.-Abundant, except in the hills, from May to June. The food-plant is Atriplex.

HESPERIIDE.

Anthomaster agricola, Boisd.-Rather common on flowers in August and September.

Anthomaster pratincola, Boisd. (?)-Several specimens taken at Black Mountain in September and October appear to belong to this species.

Hylephila campestris, Boisd.-Not rare in early fall.

Polites sabuleti, Boisd.-Flies from May to September.

Phycanassa melane, Edw.- May to October. Not common.

Thanaos propertius, Lint._Flies in early April and May quite abundantly.

Thanaos clitus, Edw.-Common. I am in doubt as to the correct identification of this and the preceding.

Hesperia ericetorum, Boisd.-Rare. I have seen but a single specimen taken in this county.

Hesperia tessellata, Scudder-Common everywhere. The fact that the life-history of tessellata has been fully described by French in his Butterflies of the Eastern United States (Supp., p. 404), appears to be overlooked. In this locality the larva feeds on Malva borealis, and I have found eggs, pupæe and larvæ in all stages. Nuch irregularity is exhibited. On October $\mathrm{r} 4^{\text {th }} \mathrm{I}$ observed a female ovipositing, and collected a number of eggs. Two eggs hatched October isth, and on the 2oth two more. The remaining two did not hatch until the middle of December. The larva emerges from the egg by eating out a round circular hole at the apex. The pupa is formed in the leaves.

Hesperia caspitalis, Boisd.-Occasional in the mountains, from April to July. 


\section{MEIGEN'S FIRST PAPER ON DIPTERA.}

Since the publication of my article in the October number, page 370-373, I have received Vol. III of Kertész's Catalogus Dipterorum, and I notice that he accepts all of the I 800 names that come within the limits of this volume, five in number. I also have received the September number of the IViener Entomologische Zeitung, in which Dr. Bezzi reviews Kertész's third volume. He makes the remarkable admission that the rules of the International Zoological Congress perhaps do not justify the use of the r 800 names, but at the same time praises Kertész for adopting them. As the admission is fatal to the case built up by Hendel and Bezzi (with the present co-operation of Kertész), I deem it advisable to quote his exact language (Wien. Ent. Zeit., XXVII, 252):

"In diesem Bande hat sich der Herr Verfasser streng an das Prioritätsgesetz gehalten; wir finden fünf Neigensche Gattungen von I800 wieder in Gebrauch gestellt, und zwar Potamida für Ephippum, Hermione für Oxycera, Eulalia für Odontomyia, Erinna für Xylopharzus und Chrysozona für Haematopota. Aus demselben Grunde sind auch Solva, Walker, für Subula (Xylomyia, Rond.), Pantophthalmus, Thunb., für Acanthomera und Rhagio für Leptis gebraucht.

"Ganz besonders hervorzuheben ist die richtige Nomenklatur, welche, wenn auch nicht inmer den neuen internationalen Regeln entsprechend, jedenfalls mit den klassischen Grundsätzen der IVissenschaft ïbereinstimmend ist."

As I showed last month, it was Dr. Bezzi and Mr. Hendel together who worked up the I 800 paper of Meigen; we now have the feeble suggestion of one of them that their proposed names, "even if not entirely in agreement with the new International rules, are, at any rate, in harmony with the classic principles of science."

I surely need not pursue the subject further.

J. M. Aldrich, Moscow, Idaho, Oct. io, 1908.

\section{A CORRECTION.}

On page 349 of this volume, the expanse of wings of Argyroploce abietana, n. S., should have been given, I I-1 $3 \mathrm{~mm}$. and not $2 \mathrm{r}-23 \mathrm{~mm}$.

C. H. Fernald.

Mailed November 3rd, I9o8. 
SOME BEES FROM IVESTERN CANADA.

BY T. D. A. COCKERELL, UNIVERSITY OF COLORADO.

I am indebted to Dr. C. Gordon Hewitt for the loan of a small collection of bees obtained by Mr. T. N. Willing, of Regina, Saskatchewan. Although the number of species is not large, several are new to the Canadian fauna, or otherwise of interest. It is in this region that the arid transition zone enters Canada, and consequently, any one who will collect diligently there is sure to find a considerable number of species not otherwise known as Canadian. I have omitted from the list three species of Andrena, two from Regina and one from Mortlach. I do not recognize these at once, and it may be that some or all are new, but it does not seem worth while to spend time on them until Mr. Viereck's paper on the genus has been published.

Colletes salicicola geranii Ckll.-I ơ, Pincher, Alta., July ro, I904. Halictus lerouxii ruborum Ckll. - + , Mortlach, Sask., May 31.

Halictus trizonatus Cress.- + , Mortlach, May 3 I.

Agapostemon texanus Cress.- + , Mortlach, May 3r, I909.

Andrena cockerelli Græn.- 9 , Lipton, Sask., June 5, I 907.

Halictoides maurus Cress.- $\uparrow$, Kinistino, Sask., July 26, 1907.

Coelioxys ribis Ckll.—ơ, Prince Albert, Sask., July 27, 1907. Like the male of $C$. ribis kincaidi, but hair a purer white, and scutellum subangulate in middle, with the lateral teeth short as in ribis $q$.

Osmia novomexicana Ckll.-Medicine Hat, Alta., one $q$, May 30 , I 904 .

Anthidium tenuiflora Ckll.— $-q$, Radisson, July 29, 1907 ; ${ }^{*}$, Sukstown, July i 8, i 909.

Megachile calogaster Ck1l._- + , Meota, Sask., July 8, 1906; + , Swarthmore, July 15, I910; ठt, Macleod, July 2, I904.

Megachile manifesta Cress.- $\sigma^{\star}$, Davidson, Aug. 2 I, 1907.

Megachile (Sayaphis) pugnata Say.- ơ, Radisson, July 29.

Megachile (Anthemois) infragilis Cress.- $\delta$, Regina, July I I, I 909. A form with the light hair yellowish-white. Anterior coxæ with no spines.

Megachile relativa Cress.-Four $q$ 's, three from Regina, Aug. 24, Sept. 4 and 7, one from Davidson, Aug. 21. Peculiar for having the hair on last dorsal abdominal segment partly or mainly black instead of orange.

Megachile latimanus Say.- $q$, Regina, Aug. 15 .

Melissodes confusa Cress.-Males from Meota, Sask., July 8; Macleod, July 8 ; Radisson, July 29 ; Prince Albert, July 28. 
Tetralonia medicata, n. sp.- + , Medicine Hat, Alberta, May 30, 904. Length, about $14 \mathrm{I} / 2 \mathrm{~mm}$; like $T$. atriventris Sm., but pygidial plate narrower (as in fuscifies Rob., from IVashington, D. C.) ; hair of head (except occiput), of pleura and under part of thorax, all black, of thorax above creamy white; hair of legs black, or nearly, except on inner side of anterior and middle tibize and anterior tarsi, where it is reddish, on middle tarsi, where it is red, brilliant on inner side, and the scope of hind legs, which is golden red; clypeus coarsely, irregularly punctured, with a median ridge; mesothorax dull, finely granular; mandibles with an orange patch; wings not so brown as in atriventris or fuscipes; abdomen without bands.

When working on this species, I had occasion to examine a cotype of Cresson's Melissodes dubitata. The specimen, which agrees excellently with the description, shows that dubitata is not Tetralonia atriventris, as has been supposed, but is a valid species of true Melissodes. It is readily distinguished from $T$. atriventris by the clypeal structure and sculpture (punctures very dense) and the shining mesothorax.

Anthophora bomboides Willingi, n. subsp.-ơ, Prince Albert, Sask., June 18, 1905. Rather small; pale hair wholly dull white; middle of thorax with a small amount of black hair; first two abdominal segments with pale hair (first three in true bomboides); sides of second segment posteriorly with black; third and following with black hair; scape with a small light spot; clypeus yellow, except a crescent-shaped black mark on each side, the convexity inward, and the lower inferior corners broadly; lateral marks reduced to narrow stripes contiguous with the black part of clypeus; labrum yellow, except lateral and apical margins, and the usual lateral spots. Proportions of antennal joints, venation, toothed hind basitarsi, etc., normal.

\section{A DECISION ON MEIGEN'S 1800 PAPER.}

BY J. M. ALDRICH, MOSCOW, IDAHO.

In the Canadian Entomologist of October, I 908 (pp. 370-373), I published a discussion of this paper of Meigen's, to which I added a brief item the next month (p. 432). Some time afterward, learning that the International Commission on Zoological Nomenclature was accepting certain nomenclatural questions for consideration, expecting to render opinions on them, I sent to Dr. Charles Wardell Stiles, secretary of the Commission, copies of what I had published on the Meigen paper, and asked him to have the question taken up by the Commission. I did not precisely specify the question to be considered, but simply gave him my 
discussion, my idea being to ascertain whether the 1800 names would be considered valid.

The opinion of the Commission was delivered to me last May, and has lately been published among others in circular form by the Smithsonian Institution (Smithsonian Publication, No. 1989, p. 68, October, 19 10).

The question is taken up in the following form:

"The question primarily before the Commission is whether Meigen's 'Nouvelle Classification' has been published or not."

Omitting the discussion, the conclusion is given in the following paragraph :

"In the face of this evidence submitted by Doctor Stejneger, it cannot be doubted that Meigen's paper has been published in the sense of the International Code, and the Secretary concurs with Doctor Stejneger in submitting to the Commission the motion that the Commission is of the opinion that the generic names in Meigen's Nouvelle Classification, 1800 , must take precedence over those in his Versuch, 1803. in every case where the former are found valid under the International Code."

This motion was agreed to by eleven commissioners, four not voting; none voting in the negative.

After receiving this decision, on May $3 \mathbf{I}$, 19 10, I wrote Mr. Stiles a letter, in which I said :

"I do not find that you have touched the point at issue. In my published articles on the matter, which I sent you, I did not dispute that the paper was published in 1800 . The question is whether the 1800 names were accompanied with enough data to make then valid. And on this I still await a decision."

Mr. Stiles's reply concludes with the following paragraph :

"You summarize your point of view in the foliowing sentence : The question is whether the 1800 names are accompanied with enough data to make them valid.' My view is that this is a question for you and other specialists to answer zoologically. The opinion in question as written is to the effect that they are available, and this is a question of the Code. Whether they are valid involves a question of systematic zoology, namely, can specialists recognize what is included under those names."

The foregoing facts will, I think, show that the Commission did not only not decide against my contention, but that the Secretary expressly says that the essential feature of the case does not lie within the jurisdiction of the Commission, and cannot be acted upon by them. 
BOOK NOTICE.

Genera Insectorum dirigés par P. Wytsman, Coleoptera Adephaga, fam. Carabidæ, subfam. Cicindelinæ, von der Walther Horn, I 910. Fascicule $82 \mathrm{~b}$ avec planches, 6-I 5 .

This, the second part of Dr. Horn's "Cicindelinæ," has recently come from the press, and is devoted to the platysternale phylum, including the tribes Mantichorini, Megacephalini and Cicindelini. The general plan follows that indicated in the review of the first part (vide Canadian Entomologist, i9io, p. 65), but so many items of interest to American entomologists appear that it seems worth while to notice them in some detail.

Under Dr. Horn's arrangement, our genera, Amblychila and Omus (together with the South American Pycnochila), form the subtribe Omina of the tribe Megacephalini. Of Amblychila, two species are recognized, cylindriformis Say (with the subspecies picolominii Reiche), and baroni Rivers (with the subspecies Schwarzi IV. Horn), the recently described longipes Csy, ranking as a synonym of baroni. In Omus only three species are recognized, dejeani Reiche, submetallicus Horn, and californicus Esch. The first two of these are without synonymy, but the string of names assigned to subspecific or other local forms of californicus is a long one. Those given specific rank are (1) vandykei IV. Horn, (2) audouini Reiche, (3) ambiguns Schpp., (4) punctifrons Csy., (5) sequoiarum C.., (6) fraterculus Csy., (7) horni Lec., (8) levis Horn, (9) edzurdsi Cr., (10) intermedius Leng, (I I) lecontei Horn, (I 2) fuchsi IV. Horn. This leaves about two dozen of the names applied by LeConte, W. Horn and Casey with no higher value than that of synonyms. The reviewer is bound to confess that his own series of Omus is too small to throw any light upon the matter. Tetracha, which is made a subgenus of Megacephala, of the subtribe Megacephalina, gets through with no change of name in our two species. The arrangement of the Cicindelini is not completed in this section, but it is divided into two subtribes, only one of which (Cicindelina) is found with us. This has not been reached, but the next part, containing it, will be looked forward to with interest and perhaps with some apprehension by subscribers to the work.

Something should be said of the plates, which are beautifully executed, and illustrate a large number of exotic forms, as well as a few from North America. As in the preceding part, a good share of the drawings are devoted to structural details. The work as a whole is to be recommended to all naturalists interested in phylogenetic studies, since it represents the views of a writer who considers the insect not as a mere separate entity, but in relation to life as a whole.

H. F. IVICKHAM.

Mailed January 12th, 19II. 


\title{
The Dipterous Genus Scellus, with one new Species.
}

\author{
By J. M. Aldrich, Moscow, Idaho.
}

This small genus, with Hydrophorus and Liancalus, forms a distinct subfanily of the Dolichopodidæ, characterized by having the last section of the fifth vein shorter than the posterior crossvein, the hairs of the back of the head below forming a scattered beard (instead of a ruff in a single row bordering the eye), and hypopygimm directed backward or downward, not turned forward under the venter.

Liancalus is readily distinguished from its near relatives by having slender fore femora and elongated fore coxe. The difference between Hydrophorus and Sccllus is not very striking when written down, but easily recognized in nature. Sccllus has long spines on the under side of the fore femora, and distinct, narrow longitudinal lines on the thoracic dorsum; Hydrophorus has only small spines on the under side of the fore femora, and the dorsum ummarked with lines, or with very slight ones. The species of Hydrophorus always frequent the edges of water, and are often seen running over its surface. Sccllus, however, is never seen at water, but is found on bark of trees, on the ground, or in grass (exceptionally, perhaps on stones).

Only six North American species of Scellus have been described, to which another is added in the present article.

\section{Scellus virago new species.}

Large species, with yellowish-brown wings and greatly elongated antennæ, with apical arista.

Male. Head densely yellowish-brown pollinose, the face more ochre yellow; eyes elongated vertically, the face slender; about eight black bristles behind the eye above, and a pair on the occiput; antennie inserted high up, as long as the vertical diameter of the eye, slender, the third joint nearly twice as long as the first two, with a short, two-jointed, apical arista.

Thorax thickly dusted, still with a faint coppery or rosaceous reflection showing through on dorsum and sides. Pollen of the dorsum grayish in the middle, with two very fine lines in the center, enclosing the single row of six or eight tiny acrostichal bristles; dorsocentral 
bristles in two rows, very small, except the posterior two of each row, with slight dots from which the separate bristles arise; along each side of the dorsum a darker pollinose stripe above the pleural suture; before the scutcllum a median darker stripe, continuing the two fine median lines to the scutellum (the insertion of the pin prevents my describing this more closely); scutellum more bright coppery red, with two bristles; pleura uniformly and densely pollinose with grey, the coppery ground color but little visible. Halteres yellow.

Abdomen less pollinose and more coppery than the thorax, of four well-developed segments, the others modified; fourth segment onethird as long as the preceding one; the "anal appendages" arise on the dorsal side, between the fourth and fifth segments-they are a pair of delicate organs, black at base, whitish beyond, each ending in a spoon-shaped, orange-colored enlargement, which bears a dense series of small, dark hairs along the outer side and a tuft of similar ones on the inner apical angle; third abdominal segment protuberant below, the grasping organs of the hypopygium projecting behind it.

Legs blackish-green, somewhat pollinose, of complicated structure. Fore femora with the usual spines beneath; fore tibiæ with a row of stiff hairs on the inner side beyond the middle and a stout thumblike curved claw on the anterior side before the end; also, witli a striking lobe or lappet on the inner side of the tip. Middle femora slender, a little arcuated; middle tibia with a row of erect bristles on the anterior side past the middle, and curled long hairs on the posterior side at the tip. Hind femora. tibiz and tarsi of plain structure, the tibia without noticeable bristles at the tip.

Wings brownish-yellow on the basal half, more brown apically; a large brown spot on the posterior crossvein and another on the arcuation of the fourth vein, before and beyond the latter vein is widely borclered with yellow. Length, including appendages, $7 \mathrm{~mm}$.; of wing, the same.

Female. Antennæ much shorter, the third joint only a little longer than the other two, arista apical, a little longer than in the male. Abdomen of five equal segments. Legs destitute of striking modifications, however, the spines under the fore femora are as large as in the male. Wings as in the male. Length, $7.2 \mathrm{~mm}$.

The type is a male, collected by myself, October II, Ig05, in the salt marshes nearest to Palo Alto, Cal. It was stalking over the ground in a bare spot, and looked more to me like a Tipulid than anything else.

I have also a male and a female cotypes, collected in the same vicinity by R. W. Doane, on October I I, Igo6. He studied the courtship of the species at that time. (Vide postcà, page 136 ). 
Notes on the Described Species.

Sccllus crustus Walk. This large, black species is so striking that there can be no doubt that it was the one described by Walker, although he mentioned only a few of its characters. I have specimens from Brookings, South Dakota, Montana, and Moscow, Idaho. I have only collected it in beating about the grass of low meadows, and have never seen a specimen before I got it into my net; hence, I do not know its exact habitat.

Sccllus avidus Loew. This I have only seen in a set of specimens given to me by Professor Wm. M. Wheeler, collected by him September II, I895, on Hunter's Crcek, Wyoming. The type locality was Fort Resolution, Hudson's Bay Territory. It is one of the larger species, the tooth on the anterior side of the fore tibia is near the base; the ribbonlike anal appendages are white, blackish at base and tip, with a tuft of brown hairs on the end of the black, spoon-shaped apical part.

Scellus spinimanus Zetterstedt. This European species was recognized by Loew in material from Fort Resolution, Hudson's Bay Territory. As far as I know, no one has seen it from North America since. It should be easily recognizable.

Sccllus monstrosus O. S. I examined a male of this species in the University of Kansas collection, captured at Estes Park, Colorado: it is the only specimen I ever saw. The type locality was British Columbia. It has many characters in common with virago, differing in the antennal structure and in having a long, curved spine at the apex of the hind tibia, etc.

Sccllus vigil O. S. Type locality, Webber Lake, California, "resting on stones on hillsides." No other species of the genuts is known to rest on stones, and I found this rather common ten years ago in the vicinity of Moscow, Idaho, on trunks of pine trees; hence, I am a little doubtful about the data of Osten Sacken. I also got the species on the side of the university building, however. It is a small species, with pale wings. I have got no more specimens for some years now.

Sccllus filifcrus Loew. I collected this at Custer, South Dakota, on pine trunks, and near Moscow. Idaho, in the same 
situation. It was not common in either locality, and I have not found a specimen in ten years.

I wish the few remarks above about the habitat of species of this genus might interest collectors in scanning trunks of trees more closely. Not only Scellus, but Medeterus and Neurigona, of the Dolichopodidx, are found there, as well as flies of other families.

Students of sccondary sexual characters could not find a more interesting group than Scellus; for lack of space, I have not half described the peculiarities of the male in virago, and all the species have nearly as many male characters.

TABLE OF SPECIES OF SCELLUS, BASED ON THE MALES.

I. Third antennal joint elongated, with apical arista . . . . virago n. sp. Third antennal joint not elongated, with dorsal arista . . . . . . . 2.

2. Hind femora greatly thickened and arcuated, wings wholly blackened.

exustus Walker.

Middle femora arcuated, thickened towards the middle, wings not entirely blackened . . . . . . . . . . . . . . 3.

Middle and hind femora not arcuated . . . . . . . . . avidus Loew.

3. Apical half of the wings black, thorax above with snow-white pollen. spinimanus Zetterstedt.

Not as described . . . . . . . . . . . . . . . . . 4.

4. Anal appendages terminating in spoon-shaped, orange-colored enlargements . . . . . . monstrosus Osten Sacken. Anal appendages not enlarged at tip. . . . . . . . . . 5.

5. Hind femora along the middle with abundant, long white pile . vigil Osten Sacken.

Hind femora without white pile . . . . . . . . filiferus Loew. 


\section{EMPHYTINE-NEIV GENERA AND SPECIES AND SYNONYMICAL, NOTES.}

BY ALEX. D. MACGILLIVRAY, ITHACA, N. Y.

The subfamily Emphytine as understood by the writer should be characterized as follows: the front wings with the first and second anal cells present and separate; the second anal cell strongly contracted at middle of the hind margin ; the radial cross-vein present ; the free part of $\mathrm{R}_{\mathbf{5}}$ always present; the radio-medial cross-vein usually present; the medio-cubital cross-vein and the free part of $\mathrm{M}_{3+4}$ parallel ; the hind wings with the free part of $R_{4}$ and the transverse part of $M_{2}$ present or wanting; the antennæ with nine segments.

Cockerellonis, $n$. gen.-Front wings with the second abscissa of $\mathrm{Cu}$ distinctly longer than the free part of $\mathrm{M}_{4}$; the free part of 2 nd $\mathrm{A}$ perpendicular; the radial and the radio-medial cross-veins present; the hind wings with the cell $R_{1+2}$ with a long appendage; the free part of $R_{4}$ and the transverse part of $\mathrm{M}_{2}$ present ; the posterior metatarsus shorter than the four following segments; the claws simple, without a tooth. Type, Cockerellonis occidentalis, MacG.

Cockerellonis occidentalis, n. sp.-Black, with the following parts reddish-yellow: the clypeus, the labrum, the mandibles except at apex, the inner margin of the eyes very narrowly, the tegulæ, the collar broadly, the wings at base and the costa, the apices of the costa, the trochanters in great part, the femora narrowly at base and apex, more pronounced on the anterior, the tibiæ except fuscous marks on the outside of the middle and posterior, the base of the tarsi, and the apex of the ventral abdominal segments; the clypeus deeply and broadly emarginate; the third segment of the antennæ one-third longer than the fourth; the ocellar basin well marked and deep ; the frontal crest prominent and not interrupted; the vertical foveæ deep, diverging behind, puncture-like, and not reaching the occiput; the head and thorax smooth; the stigma brownish-black; the wings hyaline, slightly clouded, the veins black. Length, $6 \mathrm{~mm}$.

Habitat.-Ruidosa Creek, New Mexico, 6,600 ft. elevation, July Ist, on fronds of Pteris aquilina, collected by Prof. E. O. Wooton, No. 8 , received from Prof. T. D. A. Cockerell. This species was listed as Taxonus (strongylogaster) occidentalis, MacG., MS. by Prof. Cockerell in Trans. Kansas Acad. Sci. for I898 (publ. г 899), page 2 I 2.

Epitaxonus, n. gen.-Front wings with the second abscissa of $\mathrm{Cu}$ distinctly longer than the free part of $\mathrm{M}_{4}$; the free part of $2 \mathrm{nd} \mathrm{A}$ perpendicular; the hind wings with the cell $\mathrm{R}_{1+2}$ with an appendage at apex; the October, 1908 
posterior metatarsus shorter than the four following segments together; the claws with a minute erect tooth at middle. Type, Taxonus albidopictus, Nort.

Taxonus, Htg.-This genus was described by Hartig in Die Familien der Blattwespen und Holzwespen, Berlin, 1837 . The following species were included: Nitida, Klg. (=agrorum, Fall); stricta, Klg.; bicolor, Klg., and coxalis, Htg. (=equiseti, Fall), and agilis, Klg. (=glabratus, Fall). So far as I have been able to determine, no type has been indicated for this genus, and in order that the same group of species may be retained in the genus, equiseti, Fall, should be taken as type.

Taxonus montanus, MacG.-The unique male type of this species on careful study and comparison proves to be the same as Epitaxonus albidopictus, Nort.

Taxonus floridanus, Prev.- This is a synonym of Pseudosiobla robusta, Kirby.

Taxonus unicinctus, Nort.-From a careful study of all the material at hand, I have come to the conclusion that Taxonus unicinctus, Nort.; Strongylogaster pallicoxus, Prov., and Taxonus borealis, MacG., are all one and the same species. Norton's name is the older and should be used; the species belongs in Ashmead's genus Strongylogastroidea.

Monostegia, Costa.-This genus, as near as it is possible for me to determine at this time, was proposed by Costa to include luteola, Klg. (=abdominalis, Fab.). Fabricius's species is readily separated from Poecilostoma by having the claws bifurcate at apex. The name Monostegia is used here in its original sense, and abdominalis, Fab., is taken as its type.

Monostegia Martini, n. sp.-Black, with the following parts rufous: the labrum, the collar broadly, the tegulæ, the metathorax, the abdomen, the legs, and the base of the wings; the second segnent of the antennæe as long as the fourth and fifth together; the frontal ridge wanting and the antennal fovea and the ocellar basin united. Length, $7 \mathrm{~mm}$.

Habitat.-Westfield, Mass., J. O. Martin collector.

Phrontosoma, 11. gen.-Front wings with the second abscissa of $\mathrm{Cu}$ subequal in length to the free part of $\mathrm{MI}_{4}$; the free part of 2 nd A oblique ; the hind wings with the cell $R_{1+2}$ always with a distinct appendage at apex; the posterior metatarsus never longer than the four following segments; the claws cleft, with the inner lobe not more than one-half the length of the outer lobe. Type, Phrontosoma atrum, MacG. 
Phrontosoma atrum, n. sp.-Body black, with the tegulæ, a fine line on the collar, and all the legs beyond the apical third of the femora, white; the apex of the posterior tibix and the tarsi infuscated; the antennal furrow below the lateral ocelli broad and coarsely punctured; the frontal ridge wanting and the antennal fovea and ocellar basin continuous; the third segment of the antenne as long as the fourth and fifth together. Length, $6 \mathrm{~mm}$.

Habitat.-Ames, Iowa. E. D. Ball, collector.

Phrontosoma Nortoni, MacG. - This species was described in the Canadian Entomologist, 1894 , XXVI, 324 , as a new species of Caliroa.

Phrontosoma Daeckei, n. sp.--Body black, with a rufous spot covering the collar and mesonotum; the tegulæ and legs beyond the apical third of the femora, white; the third segment of the antennæ as long as the fourth and fifth together; the frontal ridge distinct and unbroken, the antennal fovea and the ocellar basin therefore not continuous; the antennal fovea as large or larger than the ocellar basin, and extending through the hypoclypeal area; the triangular depression behind the anterior ocellus not extending to the antenual furrow. Length, $7 \mathrm{~mm}$.

Habitat.-Glenside, Mtg. County, Penn. E. Daecke, collector.

Phrontosoma collaris, n. sp.-Body black, with a rufous spot covering the greater part of the prothorax and the mesonotum; the third segment of the antennæ hardly as long as the fourth and fifth segments together; the frontal ridge distinct and unbroken; the antennal fovea long and distinct; the ocellar basin almost wanting; the triangular depression behind the anterior ocellus distinct and extending to the antennal furrow. Length, $7 \mathrm{~mm}$.

Habitat.-Ames, Iowa. E. D. Ball, collector.

Emphytus cinctipes, Nort.-Many writers since the time of Norton have considered this species as the same as the European Emphytus cinctus, Linn., while the coloration is practically identical, the form of the frontal area, the shape of the saw-guides, and the dentation of the saws is entirely different, and I believe that Norton's species should be recognized as distinct.

Parataxonus, n. gen.-Front wings with the radio-medial cross-vein always present ; the second abscissa of $\mathrm{Cu}$ always shorter than the free part of $\mathrm{M}_{4}$; the hind wings with both the free part of $\mathrm{R}_{4}$ and the transverse part of $\mathrm{M}_{2}$ wanting; the posterior metatarsus never longer than the four following segments together; the claws with a large erect tooth at middle. Type, Taxonus multicolor, Nort. 
Polytaxonus, n. gen.-Front wings with the radio-medial cross-vein always present ; the second abscissa of $\mathrm{Cu}$ always shorter than the free part of $\mathrm{M}_{4}$; the hind wings with both the free part of $\mathrm{R}_{4}$ and the transverse part of $M_{2}$ wanting; the posterior metatarsus never longer than the four following segments together; the claws appendiculately tonthed at base. Type, Taxomus robustus, Prov.

Eriocampa, Hartig.-American writers have erroneously referred the species of the genus Caliroa, Costa, to Eriocampa, and the American species that belong to Eriocampa to Stephens's genus Sciapteryx. So far as I am aware the genus Sciapteryx does not occur in America.

Sciapteryx punctum, Prov.-This is the female of Dimorphopteryx pinguis, Nort.

- Eriocampa rotunda, Nort.-This is the female of Eriocampa obesa, Say. Say described his species as an Allantus, and his name should have precedence.

Monsoma, n. gen.-Front wings with the radio-medial cross-vein always present ; the second abscissa of $\mathrm{Cu}$ always shorter than the free part of $M_{4}$; the hind wings with the free part of $R_{4}$ wanting and the transverse part of $M_{2}$ present; the posterior metatarsus never longer than the four following segments together; the head and the thorax smooth, without punctures. Type, Poecilostoma inferentia.

Poecilostoma albosecta, Prov. - Specimens of this species and Poecilostoma inferentia, Nort., are taken in this region commonly and together on Alder. Although very differently coloured, they are identical in structural characteristics; there is but little doubt that they are the male and the female of the same species.

MAcremphytus, n. gen.-Front wings with the radial cross-vein present and the radio-medial cross-vein wanting; the second abscissa of $\mathrm{Cu}$ almost obliterated by the migration of $\mathrm{M}_{4}+\mathrm{Cu}_{1}$ towards the mediocubital cross-vein; the hind wings with the cell $R_{1+2}$ extending to the apex of the wing, with a slight appendage at apex; the free part of $R_{4}$ wanting, the transverse part of $\mathrm{M}_{2}$ present ; the posterior metatarsus distinctly longer than the four following segments; the claws cleft, the rays subequal. Type, Harpiphorus variamus, Nort.

This genus is erected to include the American species referred to the genus Harpiphorus. This genus contains a single European species, which is readily differentiated by having the second segment of the antennæ longer than the first. The length of the posterior metatarsus in 
Macremphytus also prevents its confusion not only with Harpiphorus, but also with the genus Emphytus and the genera allied to it.

Strongylogaster, Dahlb.-Dahlbom in his "Conspectus Tenthredinidum, Siricidum et Oryssinorum Siandinavia quas Hymenopterorum Familias," published in the Kongl. Svenska, Vertens. Acad. Handlg. for the year 1835 , gives a list of the species of Tenthredinoidea of the Scandinavian peninsula, in which he has introduced several new names, but has not appended any descriptions. The genus Strongylogaster is such an one. Dahlbom included under this name filicis, Klg.; mixta, Klg., and cingulata, Fab. Mixta is congeneric with contigua, Knw., which belongs to the genus Thrinax, Knw.; contigua should be taken as the type of this genus. Ashmead has made filicis, Klg., the type of Polystichophagius, Ashm. This leaves only cingulata, Fab., for Strongylogaster, which becomes type by elimination. This leaves the American species of Strongylogaster in which the free part of 2 nd A is present to be provided for ; they belong to Ashmead's genus Strongylogastroidea, of which Strongylogaster apicalis, Say, is type.

Strongylogastroidea spiculatus, n. sp. - Body black, with the following parts white; the clypeus, the labrum, the four apical segments of the antennæ, the tegulæ, a very narrow line on the collar, the posterior coxæ in great part, the trochanters, and the scutellum; with the following parts rufous : the head except the ocellar and postocular areas and the lower half of the antennal furrow, the prothorax at sides, the median lobe of the mesonotum, an irregular spot on the mesopleura, the abdomen except the saw-guides, the front and middle legs beyond the middle of the femora, and the posterior tibiæ and tarsi; the anterior ocellus is situated in front of a distinct angularly diverging ridge; the saw.guides with the upper margin straight, the lower margin semi-straight, roundly and obliquely truncated and pointed at apex. Length, i I mm.

Habitat._Ellenville, N. Y. Chester Young, collector.

Strongylogastroidea confusa, n. sp.-Body rufous, with the following parts white : a narrow line on the collar, the scutellum and postscutellum, the apices of the coxæ, and the trochanters; with the following parts black: a spot surrounding the ocelli, a small spot on the middle of the postocular area, the lateral lobes of the mesonotum, the prothorax in great part, the pectus and the bases of the coxæ; the saw-guides concave above, convex below, the apex almost squarely truncate. Length, $9 \mathrm{~mm}$.

Habitat..-West Springfield, Mass. J. O. Martin, collector. 


\section{MEIGEN'S FIRST PAPER ON DIPTERA.}

BY J. M. ALDRICH, MOSCOW, IDAHO.

Johann Wilhelm Meigen ( $\left.76_{3}-18+5\right)$, was, says Schiner, "Incontestibly the first and greatest dipterologist of his time and all times." $\mathrm{He}$ had a good perception of generic characters, and had perhaps the first really comprehensive collection of European Diptera ever made upon which to exercise his talents. Added to these favouring conditions, he must also have had immense patience and tenacity to carry out through twenty years of almost continuous publication his monumental work. "Systematische Beschreibung der bekannten europäischen zweiflügligen Insekten."

Such being the prominence and reputation of Meigen, it is not surprising that considerable attention should be given to anything written by him. The paper from which many of his principal genera have been dated, and which most entomologists have supposed to be his earliest one, is entitled, "Versuch einer neuen Gattungs Eintheilung der europäischen zweiflügligen Insekten," and was published in Illiger's Magazin für Insektenkunde, Vol. II, pp. 259-28 I, in the year 1803 . The article has a page of introduction by the editor, Illiger, calling attention to the fact that Meigen had already prepared a large amount of material for a comprehensive work on Diptera, and bespeaking for him the necessary financial support for its publication. The article itself contains no explanatory matter by Meigen, but merely gives short descriptions of I 14 genera of Diptera, mostly new, with one or more typical or illustrative species mentioned in connection with most of them; a considerable number, however, have no species mentioned.

That Meigen had already published another paper with a similar scope is nowhere mentioned or suggested in the $\mathrm{I} 8 \mathrm{So}_{3}$ article, but has been known for many years. Hagen lists it in his "Bibliotheca Entomologica," although he had not seen it. It has been referred to once or twice in literature, but has remained practically unknown until recently; now, however, Mr. Fr. Hendel has published an extended article on it in the "Verhandlungen der kaiserlichen-königlichen zoologischen-botanischen Gesellschaft in Wien," I 908, 43-69. He quotes the generic descriptions in full and gives his ideas of their meaning. His own copy and the one in Osten Sacken's collection are the only ones known to Hendel. As Hagen mentions the paper as containing forty pages, it is evident that Hendel does not give it entire, but only the part which is important for October, 1908 
nomenclature. Not having seen the original, I am obliged to follow Hendel's data in the discussion which follows.

The title of the paper is "Nouvelle classification des Mouches á deux Ailes (Diptera L.) d'après un plan tout nouveau," and the date is "Paris an VIII," that is, the eighth year of the French Revoltition, or I Soo.

The work contains no mention of specific names at all in connection with the generic descriptions. The latter are brief, and in most cases in rather general terms, such as the number of joints in the antennæ, presence or absence of ocelli and tibial spurs, whether the wings are folded or divaricate in repose, etc. It is not to be denied, however, that occasional decisive characters are found, but not in many genera.

Hendel had great difficulty, as he admits, in determining the meaning or application of these generic names, until he received from Bezzi the happy suggestion that the 1803 paper contains most of the same matter translated into German, hence a comparison of the two would reveal the identity of the earlier ones. Following this out Hendel was enabled to trace the connection, and thus he learned that Meigen had changed nearly all of his generic names in $\mathbf{I} 80_{3}$ from those he proposed in $\mathrm{I} 800$. For instance, Flabellifera became Ctenophora; Petaurista became Trichocera; Zelmira, Platyura ; Fungivora, Mycetophila ; Lycoria, Sciara ; Helea, Ceratopogon; Tendipes, Chironomus; Eulalia, Odontomyia; Noeza, Hybos; Clythia, Platypeza, and many others.

A glance at the names mentioned will indicate that Meigen had in the interim adopted a new principle in the formation of generic names, changing from Latin or Latin-sounding words to those derived somewhat rigorously from Greek roots. It is possible that he was troubled with doubts as to whether any generic term would "stand" if not derived from Greek; at any rate, the nature of the changes indicates what was his purpose.

Now, a few words as to the effect upon nomenclature of this newlyopened chapter of entomological history. Mr. Hendel asserts that the older names, as ascertained by the method of comparing the German translation of the I 800 paper with the $\mathrm{I}_{\mathrm{SO}} 3$ paper, must replace the latter in toto, taking as types those assigned in 1803 . He says, "As the reader of the following pages will observe, the acceptance of the old names of Meigen will create a complete revolution in dipterological nomenclature; this is, indeed, to be regretted, but is unfortunately unavoidable. Fiat justitia, pereat mundus !" 
I am so far from coinciding in my views with Mr. Hendel that I must confess that the simplicity of his position is absolutely laughable.

I do not approach the question with the idea that two sets of names stand before the bar of justice with exactly equal claims upon our decision. The case is more nearly analogous to one that has several times arisen within a generation in the United States, when some persons have endeavoured to clain valuable tracts of real estate on the basis of transfers from Indian tribes a century or so ago. Even if the original transaction had occurred as claimed, the contestants will find that every possible presumption will be used against them, and justly so, to avoid the great practical wrong and hardship of upsetting titles to real estate. So in this case we ought to have no hesitancy in admitting that our attitude is that no old names like these can create a "revolution" unless they exhaust every legal technicality that we can throw in their way. This is not an unfair position. It does not involve an ultra-conservatism, nor does it involve a disregard of proper or generally-accepted rules of nomenclature. It does involve some comprehension of the value of stability in nomenclature, a subject on which many entomologists might cogitate long with profit.

Mr. Hendel does not cite any rules of nomenclature to justify his acceptance of the 1800 names. I will cite one to show why they should not be accepted; namely, article 25 of the International Code of 1904 , which says, "The valid name of a genus or species can be only that name under which it was first designated on the condition (a) that this name was published and accompanied by an indication, or a definition, or a description; and (b) that the author has applied the principles of binary nomenclature."

Following this rule, I note as applying to (a) above, that the names in 1800 were not accompanied by an indication, and the definition or description (these two are practically synonymous terms) were as admitted by Hendel unrecognizable (with possibly a few exceptions) until studied in the light of the 1803 paper; they were therefore nomina nuda. Condition (a) was therefore not fulfilled in 1800 . As to condition (b), if the author of a paper mentions only genera and no species, he does not apply a binary nomenclature.

Furthermore, Dr. Stiles gives as his individual rule (in his comments on the International Code, Hygienic Laboratory, Bull. 24, p. 27) : "I $2 \mathrm{a}$ Rule.-The following species are excluded from consideration in selecting 
the types of genera: (a) Species which were not included under the generic name at the time of its original publication." These names, therefore, have no types.

I should not deem the occasion to justify so lengthy a discussion on my part, but for the fact that Dr. Bezzi writes me that he is engaged on a research into the names proposed in Diptera prior to 1800 , and that he has already found data sufficient to require the change of the great majority of names of the older genera now in use in the Diptera. A number of his conclusions have already been published. We seem to be entering upon a period of nomenclatural unrest, which may leave us as badly off in Diptera as we now are in Lepidoptera or Hemiptera, to say nothing of Orthoptera and a few others.

"Let justice be done, though the earth perish," says Mr. Hendel. But justice means nothing, except with reference to some person or thing. Justice to whom, or to what? Is it justice to Meigen to insist on the use of names that he himself discarded for better ones? Or is it justice to dipterology to overturn nomenclature to no purpose? The case before us is not Meigen versus some other ancient worthy, but Meigen versus Meigen. Justice to him has already been done, and it would be flagrant injustice to reopen the case.

\section{PLATYSAMIA COLUMBIA NOKOMIS.}

The handsome moth which occurs throughout Manitoba and the Northwest Provinces, and which has always been named in collections, Samia columbia, Smith, has such a different appearance from the Ontario form which seems to be the type, that $I$ am of the opinion the name given by Dr. IV. Brodie some years ago ought to be recognized. Dr. Henry Skinner has also examined this insect critically during the past summer, and agrees with me that Dr. Brodie's description which appeared in the Biological Review of Ontario for October, 1894, pp. 103-107, should be republished. This publication is not now available, and with Dr. Brodie's consent I send herewith an extract from his article on Platysamia columbia nokomis.-Janes Fletcher, Ottawa.

\section{"Platysania Columbia Nokomis. \\ "BY WM. BRODIE.}

"In the Canadian Entomologist, Vol. X, March, I878, there is a very good coloured lithegraph of the larva of $P$. columbia, by the late G. J. Bowles, and a short paper by the late F. B. Caulfield, giving a description of the larve. There is also on page 43 an article by C. H. Fernald, 



\section{THE FRUIT-INFESTING FORMS OF THE DIPTEROUS GENUS RHAGOLETIS, IVITH ONE NEIV SPECIES.}

BY J. M. ALDRICH, MOSCOW, IDAHO.

The typical forms of Rhagoletis in North America are distinguished by their black colour, the scutellum conspicuously white or yellow and bearing four bristles, the wings with cross-bands, which may be somewhat oblique and curved; the anterior cross-vein is situated about the middle of the discal cell : first vein bristly along its whole length, the third vein only at base.

Two aberrant forms are included in the catalogue, suavis, which is pale yellow, and caurina, which does not have bands on the wing. The complexity of the relations of Trypetid genera makes it difficult to assign all species to groups where they obviously fit, and it may be better to admit these two species provisionally than to assign them to other genera without examining specimens.

Mr. Doane, Ent. News, 1898,69 , suggests that Rhagoletis zephyria of Snow is a synonym of R. pomonella, and this I think is correct.

Mr. Coquillett, Jour. N. Y. Ent. Soc., VII, 260, I \$99, refers Acidia fausta and suavis to Rhagoletis, and I also agree with this; the former, in fact, is the nearest known relative of intrudens, the new species described below :

\section{Table of Species of Rlagoletis.}

I. Colour pale yellow.................... suavis, Loew.

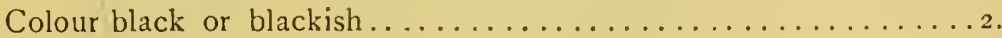

2. Wing pattern in scattered spots, not bands......... caurina, Doane.

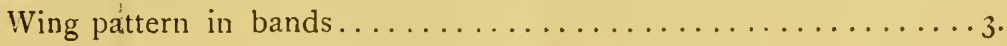

3. Abdomen with pale cross-bands..................... Abdomen without cross-bands, entirely black.............

4. A hyaline cross-band extends entirely across the wing through the distal part of the discal cell ..................... The hyaline portion not extending entirely across ...........

5. Humeral and stigmatic cross-bands confluent behind tabellaria, Fitch. Humeral and stigmatic cross-bands not connected..........6.

6. With a brown spot on the apex of the third vein... . cingulata, Loew. Without such spot.................. ribicola, Doane.

7. The entire brown pattern of the wing continuous....pomonella, Wlsh. The brown pattern discontinuous............ striatella, v. d. IV. February, Igog 
8. Femora yellow.................... formosa, Coquillett.

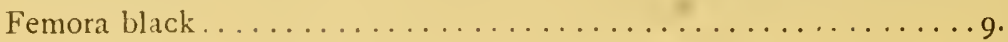

9. The humeral cross-band enclosing a hyaline triangle in

front....................... fausta, Osten Sacken.

The humeral cross-band not enclosing a hyaline triangle.intrudens, n.sp.

Rhagoletis intrudens, n. sp.

Shining black; the following parts yellow: Front, face, antennæ, except apical part of arista, palpi, proboscis, cheeks, humeri, a streak from the humerus to the wing below the dorso-pleural suture, scutellum, halteres, all the legs, except coxæ and femora. Wings as figured, the veins whitish in the pale portions and blackish in the rest; the pale portions of the membrane are distinctly white, not transparent except close to the margin ; anal cell with only a blunt point ; first vein distinctly hairy to the tip.

Chetotaxy: Postvertical pair of bristles rather large, conspicuously white, all other bristles black; vertical 2, orbital I, fronto-orbital 2 reclinate, lower fronto-orbital 3 cruciate, on lower edge of cheek r, humeral I, notopleural 2, dorsocentral I (behind the suture, there may be another where the pin is inserted), presutural $\mathrm{I}$, supra-alar 3 , post-alar 0 , scutellar 2 , mesopleural 2 (on the posterior edge), pteropleural I, sternopleural $\mathrm{x}$.

Abdomen uniform shining black, with rather coarse hairs, larger on the posterior margins of the segments; on the posterior margin of the fifth segment a row of well-developed bristles; sixth segment a little longer than the fifth, hairy; ovipositor retracted in the described specimen.

Third joint of antenna reddish, with an acute upturned point at end; arista pubescent; palpi with a few black hairs at tip.

Length, $4.1 \mathrm{~mm}$.; of wing, $3.9 \mathrm{~mm}$.

Described from one female specimen with the following label: "6.3I42. W. R. Palmer, Victoria, B. C. Emerged at Ottawa, I9, VI, $1907 . "$

It is highly probable that the same species occurs in the vicinity of Kendrick, Idaho, as I have found late sour cherries there considerably affected with a dipterous larva, which I have not reared.

A few words on the economic relations of the species may be worth while. The habits of but four species of our fauna are known; all these species are figured in the accompanying illustration, the pattern of the wing being sufficient to separate them. All the drawings are on the same 

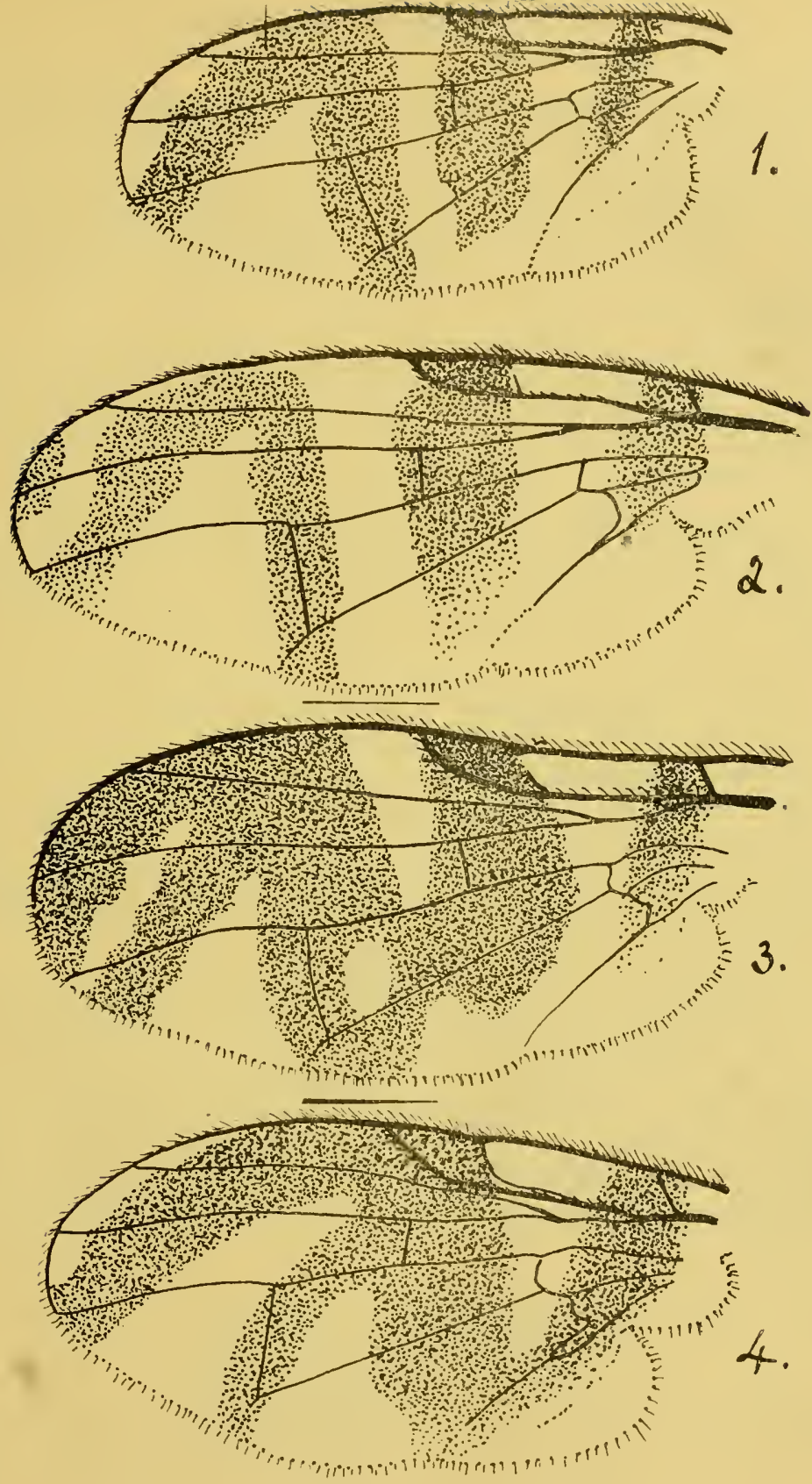

FRUIT-INFESTING'FORMS OF RHAGOLETIS. 
scale, and made with camera lucida. The upper figure represents the wing of Rhagoletis ribicola, Doane, which affects the garden gooseberry and currant in the State of Washington and in northern Idaho. It is a native species, as I collected an adult on a wild gooseberry at Pollock, Idaho, many miles from a railroad; its original foud was doubtless the wild species of currant and gooseberry, so abundant in the Pacific Northwest.

There is another Trypetid, Epochra Canadensis, Loew, that infests currants and gooseberries from Maine to Vancouver Island, but as it belongs to a different genus I allude to it here only to note the similarity of habit, and perhaps save some one from a wrong identification of its larva.

The second figure shows $R$. cingulata, an eastern species infesting cherries. It has been reported so far only from New Jersey and New York, and doubtfully from the vicinity of Boston. I am indebted to Professor Mark V. Slingerland for specimens enabling me to figure this wing.

The third figure shows our new species, $R$. intrudens, and the fourth is the apple maggot, $R$. pomonella, Walsh. The last is now pretty well distributed in the eastern United States and Canada, but has not yet appeared west of the Rocky Mountains, as far as I know, althongh I have a specimen from Colorado. Walsh, in his original article, states that the larvæ are found in fruits of Cratægus, the thorn-apple, as well as in apple. As it is a native species, we may suppose that the wild crabs and the thorn-apples were its original food-plants.

It remains only to notice Rhagoletis cerasi, Linn., which is a European species affecting cherries; it may be introduced into the United States or Canada at any time, in fact, there are one or two unconfirmed references to it in our literature already. It strongly resembles in wingpattern the first of our figures, that of $R$. ribicola, but the clear transverse band in the middle of the wing is widened in front and contains a triangular brown spot, the base resting on the costa and the apex extending to the third vein.

\section{Explanation of Plate 4.}

Fig. 1.- Rhagoletis ribicola, Doane.

$\begin{array}{llll} & 2 .- & \text { " } & \text { cingulata, Loew. } \\ & 3 .- & \text { " } & \text { intrudens, n. sp. } \\ \text { " } & 4--1 & \text { ". } & \text { pomonella, Walsh. }\end{array}$


With regard to the new species, Rhagoletis intrudens, described above by Professor Aldrich, this is the one referred to by the late Dr. Fletcher in his annual report for 1906 , page 228 , under the title, "A Cherry Fruit Fly, Rhagoletis cingulata, Loew." This insect caused noticeable damage to cherries, in 1906 , in British Columbia.

Mr. W. R. Palmer, of Victoria, B. C., in whose orchard the insect was injurious, was asked to send to the Division some living puparia, but in 1907 he wrote that he was unable to find any during the winter. Writing under date of July $20 t h$, 1907 , he says: "WVe had a harder winter than usual, and they do not seem to be as prominent. They still stick to the same tres as last season."

No reports of injury by the larvæ of this fly have been received during 1908.-Arthur Gibson, Division of Entomology, Central Experimentai Farm, Ottawa.

\section{LEPIDOPTEROUS GALLS COLLECTED IN THE VICINITY} OF TORONTO. - No. 2.

BV DR. WM. BRODIE, TORONTO.

Eucosma Scudderiana, Clemens ; Pcedisca saligneana, Clemens.

(The High Solidago Gall.)

The galls were collected usually in the spring, February and March, occasionally late in the fall, and kept in a suitable jar, until all occupants were out; always two seasons.

Annual collections were made during 12 seasons, from 1883 to 1895 , each collection averaging over 45 specimens. Most of the collections were from the vicinity of Toronto, a few from distant localities.

From $185+$ to $186+$ these galls were very common throughout North York, and are so still. I have found these galls at Owen Sound, North Bruce, Temagami, Algonquin Park, Tobermory, Manitoulin, North Bay, Essex, St. Mary's, St. Catharines, Whitechurch, Scugog and other localities, and no doubt they are common in Ontario wherever the host-plant, S. Canadensis, is found.

The galls are at the top of the main stems of the plants, usually within the flowering panicle, rarely on the branches of the panicle; usually but one gall on a plant, occasionally two, rarely three.

The galls are spindle-form, varying in size from $10 \times 16 \mathrm{~mm}$. to $12 \times 28$ $\mathrm{mm}$.; diameter of stem below gall from $4 \mathrm{~mm}$. to $5 \mathrm{~mm}$; the average of 
ten galls collected in ten seasons, 100 specimens, was $91 / 2 \times 21 \mathrm{I} / 2 \mathrm{~mm}$, diameter of stem below gall $5 \mathrm{~mm}$.

The galls are unicellular, the larvæ for sume time being closely confined in the cells. I do not think there is ever room for them to turn, and $\mathrm{I}$ am still in doubt as to their rather peculiar feeding habit.

The producers winter in the larva form, within the galls, pupate about May I, and the imagoes emerge from June I to July 5 ; the average date of emergence is about the middle of June. From June I 2 to July I I have taken specimens of the mature moth, while sweeping the hand net over Solidago blooms; it is a beautiful creature, strungly marked and readily recognized. The mature pupa pushes its way through the looselyclosed upper end of the gall, and the moth emerges into the environment of mature life.

The largest and most common parasite is Macrocentrus prediscal, Riley, easily recognized by its long ovipositor. This parasite emerges about the middle of July.

Perilampus platygaster, another parasite, emerges early in July; Cryptus extrematis still another parasite, seldom more than one individual from a gall; Pimpla annulipes also not rare. I bred Copidosoma gelechia from this gall, and once the secondary Dibrachys boucheanus.

From a lot of galls collected near Lake Simcoe, April, 1904, as well as producers and parasites, there emerged from May 2 to May r 2, I 904 , I 8 specimens of a Diplosis, very much like gall producers; but, unfortunately, from the want of material I failed to determine wisether these were gall producers or inquilines in Eucosma galls. The galls were all similar in size, shape and structure; normal Eucosma galls. In my notes I have entered as a provisional name for this species, D. eucosma.

I have found this gall restricted to the one host-plant, S. Canadensis, and there seens to be a fairly uniform relation between the producers and parasites in the vicinity of Toronto; so that year after year the galls are about equally numerous.

In Vol. io, p. 202, Caisadian Entomologist, Kellicott describes this gall, the habits and life-history of the larva and pupa of the producers.

Gnorimoschema asterella, Kell. (Gelechia asterella).

(The Solidago latifolia Gall.)

In Vol. 10, pages 203-4, of the Canadian Entonologist, D. $\mathrm{S}$. Kellicott describes this gall and its producer. 
He also gives a good engraving of the gall, but it is not that of a gall on Aster corymbosum, but on S. latifolia. The leaves at the top of the gall are evidently leaves of S. latifolia, and the anguiar form of the stem of the plant, which is always continued up the gall, is clearly shown by the engraving.

S. latifolia is one of our most common and beautiful forest flowers, having a wide geographical range over Ontario; and I have found the gall more or less common wherever the plant is found.

My first record of the gall is Aug., i 886, when I found it very common in a grand, primal, hardwood forest, in the Township of Whitchurch. My attention was directed to the galls from the fact that an ignorant old quack was using them as a cure for "fits," under the name of "Fitt Apples."

In a collection of 30 galls made May 29 , 1890 , a few miles north of Toronto, most of them were at the top of the stem, surmounted by a few leaves, occasionally but one, usually two. 'The galls at this date seemed to be mature, subtriangular, corresponding to stem of plant; from $20 \mathrm{~mm}$. to $32 \mathrm{~mm}$. long, and from $10 \mathrm{~mm}$. to $15 \mathrm{~mm}$. dia. In size, form and structure the galls closely resemble galls of $S$. gallicesolidaginis. Rarely they occur on the middle and lower third of the stem of the plant.

From June 29 , i $\delta_{9}$ r, to June 25, i $S_{96}$, anmual collections of galls were made. Galls collected before the middle of June were immature, and seldom gave either producers or parasites. The producers had emerged from all the galls collected after the middle of August, but often contained larvæ and pupe of parasites, Cryptus, Pimpla, Copidosoma, Ephialtes. The emergence of the producers was from July 28 to Aug. 20 in each season.

The following is an entry from my notebook, dated July i I, i 893: "Collected from wooded hillside, in St. James's cemetery, 35 galls, all terminal on stems of S. latifolia, all overtopped by a tuft of leaves, usually but two ; plants not much dwarfed, but no flowers. July 13, I 893 , from a wooded hill on the Don, collected 40 galls, all but one terminal, two galls on one plant."

From Aug. 7 to Aug. 20, IS93, producers emerged, and from July I 7 to Aug. 17,1893 , four species of parasites: two Pimplas, one Cryptus, one Ephialtes emerged; Copidosoma occasionally the following spring, June, I, r 894 . The galls on growing plants appear to be full size, but still 
solid, no open cavity, larva strictly confined in centre of gall, $3 \mathrm{~mm}$. long. The parasites which I have bred from this gall are $P$. conquisitor, $P$. inquisitor, C. extrematis, Ephialtes sp., C. gelechia.

The structure of the galls, the habits of the larvæ, and the mode of exit from the gall, are very similar to those of G. solidaginis, and are all very fully described by Kellicott, in the article above referred to.

I have found what seems to be a lepidopterous gall, very rare about Toronto, on stems of Aster corymbosum, a spindle-form gall inmediately under the flowering panicle, not at all like the gall figured by Kellicott but $\mathrm{I}$ failed to rear anything from them.

I found A. corymbosum very common all through the Temagami district, and the gall not especially rare, but as the galls I collected were immature, neither the producers nor parasites emerged from them.

The OtTawa Naturalist for January consists of a series of tributes of respect and affection in memory of our deeply-lamented friend, Dr. James Fletcher. A meeting of the Ottawa Field Naturalists' Club was held on the first of December, and appreciative addresses were given by many colleagues and friends, all expressive of the highest admiration for his varied scientific attainments and the warmest affection for him whose kindness, geniality and unselfishness won the hearts of all who knew him. Mr. W. H. Harrington, an almost life-long companion, gives a most interesting account of their early days together, when they explored forest and field and strean collecting insects and plants, and how the intimate knowledge of nature thus obtained caused him to become such a recognized authority in both botany and entomology. All these addresses will be read with the deepest interest by the many friends of him whom they commemorate.

\section{HONOLULU, HAWAIIAN ISLANDS.}

About the middle of May the Hawaiian Board of Agriculture and Forestry hcpe to be in a position to engage an assistant entomologist. They want an economic entomologist inclined to take up Coleoptera or Parasitic Hymenoptera as a specialty, and one who is good at laboratory and field work. Their equipment and library are good. Salary $\$ 1,500$ to $\$ \mathrm{I}, 800$ per annum, depending upon the man. The climate of Hawaii is unexcelled and opportunities good. Correspondence might be opened now. State age, schools, experience; also give references. Address : J ACOB Korinsky, Superintendent of Entomology, Board of Agriculture and Forestuy, Honolulu, Hawaii.

Mailed February 6th, Iq09. 
MERISTIC VARIATION IN CORYIALIS CORNUTA, LINN.

BY H. F. WICKHAM, IOWA CITY, IOWA.

Records of duplication of members in hexapod larva are so rare that I submit the subjoined account, drawn up from a specimen of the young of Corydalis cormuta, captured in the river near Iowa City, several years ago. The insect is one of a number that I took for class dissection, and as far as noted, the reinainder did not depart from the ordinary type. A notice of the case was prepared at the time and sent to a scientific journal on the eve of its suspending publication, so that $I$ think the article was never printed.

The larva under discussion measures, in its preserved state, about an inch and three-quarters in length. The duplication of parts concerns the left hind leg, where the femur, which is normal, bears a bifurcate tibia, one branch of which is longer than the other. The longer side attains a length about equal to that of the right tibia, and bears a tarsus which is approximately normal, though the claws are nearer together than usual;

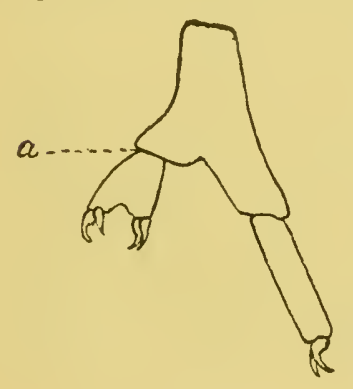

Fig. 8 . the shorter side of the tibia supports a tarsus, which in its turn shows a decided tendency to bifurcation and carries two pairs of claws.

The proportions of the parts are shown in the figure. (Fig. 8.) I am not certain that the short tarsus is drawn in proper perspective, as I accidentally broke it off at the joint marked $a$ in the figure, and may have twisted it in replacing. The specimen is preserved in my collection.

\section{PREOCCUPIED NAME.}

I refer to Prof. Fernald's kind notice of my "Hawk Moths," CAN. EnT., 98, I 887 , for the statement that the generic term Atreus is preoccupied, having been used by Koch in 1837 for a genus of Scorpions. I should not have troubled myself further in the matter of changing this name in the Sphingidæ, seeing that Prof. Fernald believes a separate genus for plebeia from Protoparce unnecessary, except that Rothschild and Gordon, in their exhaustive revision of the Sphingidæ, just published, retain the name Atreus and criticise my calling the species "plebeius," instead of plebeja. So I change the name Atreus, Grote, ISS6, to Paratrea, with P.plebeja as type.

A. R. GROTE. 


\section{DO WE KNOW CULEX CONSOBRINUS, DESV.?}

BYं J. M. ALDRICH, MOSCOW, IDAHO.

Desvoidy published this species in 1827 , in the Memoirs of the Society of Natural History of Paris, Vol. III., p. 408. The entire description is as follows :

\section{" 27. Culex Consobrinus, R. D.}

Simillimus precedenti ; palpis, tarsisque bruneis.

Long. 3 lineas.

Omnino similis Culici pipienti: differt solum palpis tarsisque brunicosis, non flavis.

Habitat in Pennsylvania. (Musæum Dejeanianum.)"

The species preceding this, to which reference is made, is Culex pipiens; the length in that is also given as three lines. Nothing is said about the palpi and tarsi, further than the expression "pedes flavescentes."

This species remained unrecognized until 1896 , when Coquillett, in Howard and Marlatt's Bulletin on "Household Insects" (Bull. 4, n. ser., Div. of Ent.), claimed to have identified it with a common and widespread form. He gave the following synonyms: Punctor, Kirby; impatiens and pinguis, Walker, and inornatus, Williston. The synonymy had been made out entirely from descriptions, save in the case of inornatus, of which IVilliston's type was in the National Museum for comparison. In Circular No. 40, Coquillett adds as probable synonyms, Anopheles annulimanus, Van der IVulp, and Culex testaceus, Van der Wulp.

Dr. Howard transmitted specimens of this supposed consobrinus to Theobald, who accepted them at their face value and redescribed the species in his Monograph of the Culicidæ, Vol. II., p. 78 . He found from Kirby's type in the British Musenm that punctor is a distinct species, which he redescribed on p. 75. As to Walker's species, he makes the following notes:

"Culex impatiens, Walker, may be this species (Coquillett's consobrinus), the type answering in nearly all respects, but the abdominal banding differs.

"Culex pingruis, Walker, may also be synonymous, but I do not know where the type is, and Walker's descriptions seem almost valueless, judging from the types I have seen."

July, 1903. 
Speaking of Anopheles annulimanus, Theobald says $\left(\mathrm{I}, 2 \mathrm{I}_{3}\right)$ : "Coquillett thinks this species does not belong to the genus Anopheles at all. The description, he seems to think, applies to a male of Culex consobrinus, Desvoidy; but in this I can scarcely agree, and do not think such an authority as Van der Wulp would commit such an error."

As to Culex testaceus, Theobald received a specimen from Lake Simcoe, Ontario, which he identified as this species, making it distinct from the supposed consobrinus.

Now let us see whether the colour of the palpi and tarsi, as indicated by Desvoidy, is sufficient to distinguish a species from pipiens. Taking the full discussion of pipiens given by Theobald (Monogr., Vol. II., pp. $132-136)$, it is immediately seen that the female has "palpi thick, brown, with some grayish scales"; also "tarsi uniformly dark brown." In the male the palpi are "light ochraceous brown," and the "tarsi dark brown." Desvoidy's specimen was in all probability a female. It appears, therefore, that his distinctive characters are normal in pipiens! At any rate, pipiens is a variable species, and easily includes forms with all his characters.

The size given by Desvoidy is the same for both species, 3 lines. If I understand this correctly, it is about $6 \mathrm{~mm}$. Theobald gives 4.5 to 5 $\mathrm{mm}$. for pipiens, and 6 to $7 \mathrm{~mm}$. for consobrinus. The advantage here is perhaps a little on the side of a distinct species ; still, Desvoidy expressly makes it the same size as pipiens, which he speaks of as a very common species, so it works about as well one way as the other.

When I came to the conclusion, some time ago, that the real consobrinus is nothing but pipiens, which is known to occur in the United States as well as Europe, I wrote to Theobald and Coquillett in regard to the matter. The former replied that he had accepted the species on the supposition that Coquillett had examined the type of Desvoidy. The latter only wrote, "Repeated revisions of my first reference of Culex consobrinus have not caused me to change my opinion in regard to it. Size and colouring both apply better to this form than to fipiens or any of our other species."

I have shown exactly how much there is in the matter of "size and colouring."

The species which is now passing under the name of consobrinus I think should be known as inornatus, Villiston. It was described in the Diptera of the Death Valley Expedition, North American Fauna, No. 7. 
p. 253. The type of this description, as above stated, has been examined by Coquillett and found identical with the species under consideration. There is no other name which is not open to serious doubt.

Consobrinus, Desvoidy, may stand unidentified. Should anyone feel under necessity to "do something" with it, let him place it as a synonym of pipiens. Certainly no one can prove that it does not belong there, unless he can examine the type. In looking up Dejean's collection in Hagen's "Bibliotheca," I find considerable information as to certain families of Coleoptera and Leyidoptera, but nothing about the Diptera. The collection was divided, and the various parts scattered in a dozen places. So there is but little prospect that the type of consobrinus can be found.

The rapidly growing importance of the Culicidæ will, I trust, excuse me for occupying so much space in the attempt to set right one of our common species.

\section{GOT WITHOUT SEEKING.}

As I was sitting in Victoria Park, London, Ont., on one of the early days of August, I902, a sharp click on my straw hat indicated to me that a beetle had been suddenly arrested in its erratic flight. I took off my hat and found thereon a longhorn, with the familiar outline and ornamentation of the old Clytus group. But there was something about it that seemed unusual to me, and the more I looked at it the more I was convinced of its novelty. So I secured it, killed and mounted it, and, as opportunity presented itself, endeavoured to determine it, but could find nothing with which it would correspond, and the books afforded me no relief. Having occasion to require the assistance of MIr. W. H. Harrington, Ottawa, upon some B. C. beetles, I sent my unique in order to secure his verdict upon it. He pronounced it to be Xylotrechus 4-maculatus, and remarked, "This is an interesting species, of which I have only taken one example, and that is of a yellowish colour." (Mine is whitish in the colour of its ornamentation.) " 4 -maculatus is said to be very variable in colour, so I think your specimen belongs to that species, although differing so mucls from mine." And that specimen now stands in what was before a blank in the Society's collection. J. Aiston Moffat.

Mailed June 3 oih, I903. 


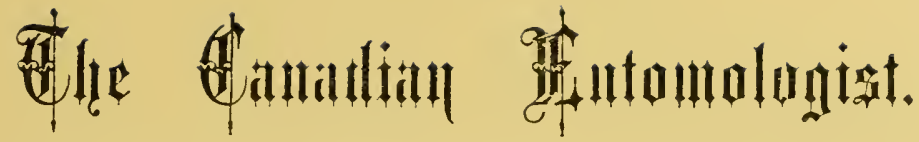

VOL. XLII.

LONDON, APRIL, I9ı.

No. 4 .

GEORGri IVILIS KIRKALDY.

I $873-19$ io.

The fulfilment of sad duties is the lot of man. To me has come that of making known the death, in the flower of his manhood, of George Willis Kirkaldy, my good friend.

After a separation of some months from his wife and little one, whom he worshipped, he went to San Francisco, where they were, to spend the Christmas holidays with them. While there he was induced to submit to a fifth operation on an old fracture of the leg, and although it. was successful, he grew gradually weaker and weaker, and less than a week later, on the 2 nd of February, he breathed his last. 'That acute intellect, that ceaseless, untiring worker was at rest. His course was run, and he fell ere he grasped the bays that were to crown his achievement.

George Willis Kirkaldy was born at Clapham, near London, England, in 1873 , and was therefore in his 37 th year. From his youth he evinced a great love for natural history, but after finishing his studies in the City of London School, he went into the city, where he remained until I903, when he accepted a position in Honolulu, with the Hawaiian Department of Forestry and Agriculture. Then began the happiest and most productive period of his life, and there also he met with the accident that eventually was to deprive the world of the most promising of the younger generation of scientific hemipterologists. Shortly after his arrival in Honolulu, while out riding, he forgot the American rule of the road, and turned his horse, after the English fashion, to the left as he came to a turn in the road, and crashed into a carriage coming in the opposite direction. His horse fell on him and crushed his leg. This was badly set, and after the bones had knit, it had to be broken again and reset. This operation was repeated at intervals no less than four times, the last with fatal results. There, too, he met the lady who became his wife; there his little ones were born, and his little son, George, the first and best beloved, died in infancy.

Freed from the sordid details of clerical work, in his new position he was in his element. He did not, indeed, care greatly to work on other 
groups of insects, and at times the daily routine of the economic entomologist was irksome, but nevertheless, whatever he did was done well, and he found time to dedicate to his researches in the Hemiptera, although nearly all the work he did was done at home in the evenings, after the day's task was over. Yet, in spite of the limited time at his command, he was able to produce enormous quantities of work of the highest character. At some time in the near future I hope to be able to give at greater length an account of his work. For the present, I shall merely mention his great work on the Jassidæ in connection with the Sugar Planters' Association work on the parasites of the sugar cane, and the general Catalogue of the Hemiptera, now in course of publication, both of which mark epochs in Hemipterology. like every earnest worker in the Hemiptera, the nomenclatorial chaos into which the order had fallen soon forced itself upon his notice, and much as he disliked to neglect the biological phases of the group, he was impelled to endeavour to place this important branch of the subject on a stable basis. In the pursuit of this laudable object, he was forced by the sheer logic of circum. stances to take radical and iconoclastic measures, but he regretted just as keenly as any of his opponents and critics the necessity of doing away with many a name hallowed, as it were, by long usage.

Kirkaldy had all the vivacity and ardour of the Celt, which may at times have led him to accept perhaps too quickly and maintain too enthusiastically views which a more mature judgment showed to be untenable. Joined to this was a relentless Scotch logical temperament, which drove him inexorably and unswervingly to conclusions which at times were opposed to his natural inclination, yet which his passion for truth compelled him to accept and battle for. Above all things he hated sham; he loatled that spirit of pompous and self-sufficient importance which curses some small men. A constant and tireless worker, a minute, patient, resourceful student, he ever looked singly to the advancement of the knowledge of the Heteroptera, that group so sadly and shamefully neglected in comparison to other orders. In that bright galaxy where shine the illustrious names of Fabricius, Burmeister, Dufour, Amyot, Fieber, Stal, and in our days, most happily still with us, of Reuter, Horvath, Montadon, Bergroth, his is not the dimmest, and had Azrael held his hand, he had shone among the most brilliant.

As for me, I have lost a leal friend, an inspiration and a lode-star; one who encouraged me when I was faint, who helped mẹ when I fell; to 
whose constant words of cheer I owe what little success I may have achieved. Our minds moved in harmonious accord; our gifts were complementary to each other, and in so far as one so insignificant might, I helped my friend in my small way, a feeble return for his many kindnesses.

Better than any, perhaps, I can gauge the loss to science by his untimely death. His work planned, ontlined in many a letter, carried out with his enthusiasm, his thoroughness, his energy, was destined to place him on the same lofty, still eminence where sits Stal alone, beyond the reach of the petty bickerings and disputes of the pseudo-great.

"And so the grim reaper reapeth among the flowers."-J. R. DE LA Torre Bueno, New York.

\section{A DECENNIAI, CONFESSION.}

B Y J. M. A L D R I C H, II O S C O I, I D H O.

In Entomological News, XI, 531, I 900, I published a list of corrections to my work on Diptera up to that time; the decade since then has, I regret to say, furnished me with materials for a similar list at the present time. With due humility I make the following confession:

In the February, 1909, number of the Canauian ENtomologist I published a paper on Rhagoletis, describing a new species, intrudens, which had injured cherries in British Columbia and presumably in Idaho. Immediately after the publication of the article, Mr. Coquillett informed me that my new species was the same as Osten Sacken's fausta, of which he had material from the type locality. Since then I received a pair of fausta from M. C. Van Duzee, collected at Kearney, Ont. 'There is no doubt that I misunderstood a statement of Osten Sacken's, where, after mentioning the basal cross-bund of the wing, he goes on to say, "The black colour begins exactly where it does in fig. xo, and encloses a hyaline triang!e reaching from the costa to the interval between the third and fourth veins." Eastern specimens prove that this statement refers to the black colour in general, not to the basal cross-vein.

In the same article I should have included in the table Rhagoletis srindelice Coquillett, (Proc. Ent. Soc. Wash., IX, I 46,) reared from flowerheads of Grindelia squarrosa at Clarendon, 'Iexas; it is readily distinguished from all the species in my table by having the scutellum wholly black. The life-history of Rhagoletis suavis I,oew, was already known, having been published by Babb, (Ent. News, XIII, 242); the larva lives in the outer hull of growing walnuts at Amherst, Mass. So there are six species with larval habits known, instead of four.

April, rgı 
In Transactions of the American Ent. Soc., XXXIV, 67-100, 1908, I published in conjunction with one of my students, P. S. Darlington, a revision of the Helomyzida. The Eccoptomera americana Darl., therein described is a synonym of E. simplex, described four years earlier by Coquillett from Nevada, and overlooked by us. The genus Siligo, Ald., in the same paper is a synonym of Zagonia, Coq., (Invert. Pacif., 27), and belongs to the Geomyzidx, as correctly placed by Coquillett. My species oregona appears to be distinct from his flaza; my litorea, however, is a Geomyza, differing in the dark body colour and bristles, and narrower cheeks. The genus Geomyza has not heretofore been reported from North America, but I have three species from the California region and a single specimen of a fourth species from Lawrence, Kans. Named European specimens of Geomyza in Professor Melander's collection put me right on this genus. My ignorance of the family Geomyzida was responsible for my mistake; there is really a close relation between Helomyzidæe and Geomyzida, some of the latter having setules on the costa. The main difference is in the auxiliary vein, distinct in Helomyzida, not so in Geomyzida. I drew the wing of Siligo from a specimen mounted in balsam, wherein the pressure of the cover-glass had separated the auxiliany and first veins to an abnormal extent. It was a consolation to read since the discovery of my error that Joew once described a Geomyza lurida, which on examination of the type turns out to be a Leriu (Czerny, Wien. Ent. Zeit., XXII, I 26 ):

In Biologia Centrali-americana, Diptera, I, 342, I described a genus of Dolichopodida under the name Phylarchus. Not having the curront numbers of the Zoological Record at hand, I did not know that Simon had used the name for a spider in I $\$ 8 S$. My fly of course cannot maintain her ground before a spider, hence I propese the genus PROARCHUS to replace Phylarchus for the fly.

In some notes on Scellus (Ent. News, XVIJI, I 35), I stated that I had collected Scellus rigil on trunks of trees. The statement was made from memory, and I now believe that I never collected it except on walls of the University buildings at Moscow, filiferus being the one that frequents pine trunks in this region. Thus my observations correspond entirely with Osten Sacken's.

In Canadian Entomologist, XXXVI, 46, I undertook to determine what name should be used in the place of Psilopus of authors, which has 
been asserted for a generation or two to be preoccupied. I am glad, indeed, to learn (Sherborn's Index Animalium, quoted by Bezzi, Wien. Ent. Zeit., XXVI, 53), that the use of the term Psilopus by Poli in Mollusca in 1795 was not in a nomenclatural sense, and hence does not constitute a preoccupation of the name, which should therefore stand for the dipterous genus.

\section{WISCONSIN BEES - NEW AND LIT TLE-KNOWN SPECIES.}

by S. Grænicher, PUblic MUSEum, MilwaUke.

Perdita F. Smith.

In the eastern part of Wisconsin this genus is poorly represented. In the region around Milwatuee only two species have been met with so far, one of these P. maura Ckil., and the other a new species described below. Along the St. Croix River, in the north-western corner of the State, three species were obtained (Milw. Publ. Mus. coll. exped.), two of which are new, while the third, P. Bruneri Ckll., had up to the present time not been found farther east than Nebraska. It is more than probable that careful collecting along the western border of IVisconsin will add some more species of Perdita to the bee fauna of our State.

\section{Perdita pallidifennis, n. sp.}

Female.-Length about $S \mathrm{~mm}$. This is a third member of the albifennis-lacteipennis group. Head and thorax blue-green. Front and vertex dull, face, thorax and abdomen shining. Mandibles curved as in albipcmis, with reddish tips. On the clypeus a yellow spot on each side in addition to the cuneate-yellow median line. Adjoining the clypeus a yellow mark on each side of the face. Scape in front, a line on prothorax, and tubercles yellow. Flagellum black, a trace of reddish near the tip. Legs dark, with no yellow markings, except on the knees of front and middle legs. Tegula yellowish on the upper half, brown below. IVings white, nervures and stigma pale. Abdomen black, usually lighter on the apical depressions of the segments. On the first segment a small yellow dot on each side, situated on the margin. A subbasal yellow band, narrowed medially, on each of the four succeeding segments, interrupted on segments 2, 3 and 4 , or at least on 2 and 3. Pygidium dark brown, shining. Pubescence of vertex and mesonotum yellowish and erect, long on the vertex, short on the mesonotum. On cheeks and pleuræe the hairs are white and long, those on the legs of a dirty-yellow colour.

Aprit, 19 ro 
Male.-Slightly smaller than the female. Pubescence white all over. No median yellow line on the clypeus, and the lateral marks are smaller than in the female. These are connected with each other by a yellow line along the apical border of the clypeus. The lateral face marks are small, the yellow line on the scape is inconspicuous or nearly absent, and the same is true of the yellow line on the prothorax. No yellow on tubercles. Legs coloured as in the female. Yellow of the abdomen confined to a small lateral spot on each side of the second segment, situated on the margin, and similar, exceedingly small spots on the margins of the third segment, and rarely of the first as well. Pygidium reddish yellow.

Types: Mouth of Yellow River, Burnett Co., Wis., July $2 S-31$. I 909 . (Nos. 31730 and $3173 \%$ )

Paratypes: One male, mouth of Yeliow River, July 28-31, I909; four males and two females, Kettle River Rapids, Aug. 4, r 909, and one male, Randall, Aug. 5, I 909, all of these lucalties in Burnett Co. along the St. Croix River. Specinens in the collection of the Milw. Publ. Museum. They were taken on the flowers of Rudbeckia hirta and Helianthus occidentalis. This species is distinct from $P$. albipennis $\mathrm{Cr}$., and $P$. lacteipennis Swenk \& Cockerell, one of its main characters being dark legs with a trace of yellow around the knees only.

\section{Perdita maculipennis, n. s]?.}

Female.-Length 6 to $7 \mathrm{~mm}$. Head and thorax dark green, legs and abdomen brownish-black with yellow markings. Body clothed with white pubescence, longest on legs and tip of abdomen. Wings white, with a conspicuous black dot in the stigma.

Head broader than long. Flagellum black above, reddish-yellow below. Scape light yellow in front. Clypeus yellow with two longitudinal black bars, not reaching the apex. I ateral yellow face-marks triangular, running half way up the face. Apex of triangle rounded or truncate, the base often emarginate. These face-marks are very variable; in one specimen on one side of the face a division into two small spots is noticeable. Mandibles yellow, with reddish tips. lubercles, tegulae and two spots on prothorax yellow. The metathorax has a more bluish tinge than the rest of the thorax. Abdomen with two yellow spots on the first and interrupted yellow cross bands on the anterior half of the second, third, and fourth segments. The spots on the first segment may be absent, and the bands on the remaining segments may be so widely interrupted as to form small spots only. Pygidium reddish. In front and middle legs, tips of femora, 
anterior surfaces of tibiæ and metatarsi yellow. Hind legs without distinct yellow markings. Wings milky-white, with pale veins and stigma. An oval black spot in the stigma takes up the greater part of its area, leaving only a portion of the base, and a narrow strip along the costa unoccupied.

Type taken August 13, 1905, at Milwaukee, Wis., flying around its nest in sandy soil. (No. 3 I 740 .)

Fourteen paratypes, Aug. 6 and 13, I905, and June 30, 1906, from the same locality, all of them obtained in the vicinity of their nests.

This species is easily recognized on account of the black spot in the stigma, a character which it has in common with $P$. maculigera Ckll., but the latter is a yellow insect with dark markings, while in maculipennis the dark predominates.

\section{Perdita citrinella, n. sp.}

Female.-Length about $6 \mathrm{~mm}$. Pale lemon-yellow with a greenish tinge in the metathoracic region, and black marks which are distributed as follows : Ocelli, a spot, usually diamond-shaped on each side of the front, situated half-way between the upper ocellus and the base of the antenna ; between this spot and the eye a narrow line extending to a point opposite the base of the antenna; a large spot on the thorax underneath, occupying the area between the anterior and middle coxæ (mesosternum) and a smaller spot in front of this (prosternum), both spots reaching the pleural region; on the margin of the second abdominal segment a short slender line; on the anterior surface of each femur a conspicuous shining longitudinal band. These markings are more or less developed in all of the specimens, and in addition to these some specimens show a dark coloration of the sutures of the face and thorax, a black spot on the hind surfaces of the hind tibia near the tip, black hind tarsi, and narrow black apical bands across the abdominal segments, dorsally as also ventrally. In the latter case the bands are more in the basal region of the segments. There may be also two or more minute black dots on the clypeus. Antennæ reddish below, black abore. Mandibles yellow, with reddish or brownish tips. Pygidium reddish-brown. IVings white, with light veins and stigma. Soft white pubescence on legs, lower part of thorax and apex of abdomen, moderately close on legs, otherwise sparse.

Type : August 13, r 909, North Hudson, St. Croix Co., Wis. (No. 30389 .)

Six paratypes, Aug. I 3 and 14, I909, at the same locality. Type and paratypes in the collection of the Milw. Publ. Museum. 
This bee collects pollen from the flowers of Petalostemum villosum (Leguminosce). There are two western species, P. perpallida Ckll., and $P$. wootonce Ckll., which are evidently extremely close to $P$. citrinella, but which collect pollen from different plants. The three seem to be very unstable in their colour characters, they have probably originated from the same ancestral form within comparatively recent times, and the fact that they visit different flowers in the regions where they have been observed, so far, does not exclude the possibility of their belonging to one species only. Hatictoides Nova-anglice for example obtains pollen at Waldoboro, Maine, from the flowers of Pontederia cordatic only, as reported by Mr. John H. Lovell (Psyche XIII, p. 112 ), at Milwaukee and at Cedar Lake, Washington Co., IVis. (about 30 miles north-west of Milwaukee). I have never seen it collecting pollen from the flowers of any other plant but Monarda fistulosa, and in Burnett Co. in the north-western part of IVisconsin I repeatedly saw it visiting the flowers of Agastache faniculum for the same purpose.

(To be continued.)

\section{A CORRECTION.}

In the January number of the Canadian Entomologist, p. $\delta$, the late Mr. G. W. Kirkaldy corrected some preoccupied generic names in insects. Among these he proposed Americides for Dryope Ch., the latter name being preoccupied in Diptera and Crustacea. However, Mr. Karl R. Coolidge had already proposed Dryoperia for Dryope Chamb. See Entomological News, Vol. XX, p. 112.- IV. G. Dietz.

Esperanto, the international language, if it has not done so before, has at last invaded the entomological field. Mr. Tor Helliesen, of the Museum in Stavanger, Norway, has just published a list of Coleoptera new to that country, and has added a resumć in Esperanto.-H. S. SAUNDERS. 


\title{
Collecting Notes from the Great Basin and Adjoin- ing Territory (Dipt., Col.).*
}

\author{
By J. M. Aldricir, Moscow, Idaho.
}

In the summer of I9I I I traveled about 5000 miles in a 62-day expedition having for its main object the study of the insects found in and about the western salt and allialine lakes. Although I have published four articles on my results and have another in press, there are so many facts of entomological interest remaining that a more general discussion of the theme seems to be required. Much of my material outside the Diptera still remains unidentified, hence it is even yet impossible to give a list of the species collected. Nor do I think such a list wholly desirable, as it would contain only here and there a species of real interest, nine-tenths being comparatively common and widespread insects. The better way would be to enumerate only species not heretofore known in the territory under consideration, or those whose distribution is little understood. This plan will be pursued with the Diptera, while other orders must wait indefinitely.

The first three weeks of the trip were spent with a farmers' institute party from the University of Idaho, to whom had been assigned a schedule of institutes mostly in rather out-ofthe-way places. Our itinerary took us to Payette Lake and down Long Valley to the southward, a fine collecting ground for all kinds of insects, and now becoming accessible through the construction of a branch railroad from Nampa. We were there too early, about June 20 ; nearly a month later would have been better. The valley is bordered on both sides by heavily timbered and snow-capped mountains, the summits being only a few miles from civilization, ideal for entomological work. Along the main line of the Oregon Short Line as we progressed eastward there is nothing of especial interest in the way of a collecting ground until Pocatello is passed. East of this point the railroad enters a mountain valley, and the entomological field is highly interesting until the Wyoming line is reached. We left the railroad at Montpelier and made

*Part of the results of an investigation made by aid of an appropriation from the Elizabeth Thompson Science Fund. 
the interior points of St. Charles and Liberty. This also is a high country and it was early for good collecting. The next and concluding institute was at Malad City on July 3, and from here my trip of investigation began. I had collected so far only the following Diptera of special interest:

At McCall, Idaho, on Payette Lake, Asemosyrphus mexicanus.

At Council, Atherix variegata.

At Boise, Heteropterina nasoni and n. sp.

At Soldier, Tabamus phacnops.

At Bellevue, Campsicnemus thersites, Dolichopus coquilletti, Chrysopila tomentosa.

At McCammon, Pclina truncatula, Tephritis clathrata.

On the roundabout railroad trip into Malad, a day had been spent on a side trip to the Utah Agricultural College at Logan; while awaiting the train at Cache Junction, I collected Dolichopus amnicola and Hydrophorus gratiosus Ald. In Logan I found Chiromyia (Scyphella) flava common on a stable window.

At Brigham City, Utah, on July 4 and 5, I spent the available time at Box Elder Lake, an expanse of brackish, shallow water about two miles north of town. On the way thither along the railroad were great quantities of parsnip in bloom. On these I got three species of Thereva and specimens of Helophilus similis and Sarcophila (Paraphyto) opaca. Along the shores of the lake or pond I found a new species of Lispa (described in a forthcoming paper), also Ephydra subopaca, which breeds in the salt waters; in the adjacent grasses along a waste water ditch occurred Mclicria occidentalis and a new species of Pelastoneurus, while I was attacked by Chrysops discalis, fulvaster and mocrens. On the bare mud, where the lake had recently dried away, there were many specimens of Cicindela ccho, somewhat difficult to capture from a bad habit of flying a long distance when flushed; they enter the shallow water fearlessly and run about in it where it is a quarter or three-eighths of an inch deep, capturing some kind of prey there. In this situation they are unable to take wing, and I picked up a few specimens from the water in my fin- 
gers. This habit in a Cicindela was new to me. In the vicinity of the pond I got Dolichopus afflictus, which is unusual so far east, although it has been reported from Wyoming.

About Salt Lake City there is of course much to interest the entomologist. The electric line up Emigrant Canyon gives a ride up to about 7000 feet altitude for 80 cents, and should never be overlooked by collectors who visit the city in summer. Near the end of the line, high up in the mountains, I captured Dolichopus n. sp.. Tachytrechus n. sp. and Hydrophorus philombrius. The shores of Great Salt Lake are easily accessible by going to Saltair or by taking the local trains which run out to Garfield and Smelter station next beyond. The local train turns round on a $\mathrm{Y}$ just beyond Smelter, and from this it is only a short distance to the shore of the lake. There is some brackish water in spots between, around which I collected, but the shore of the lake is a particularly rich field. Ephydra gracilis occurs by millions, the larva living in the water; Ephydra hians is also numerous in places on the shores, and likewise lives in the water in the larval stage. Cacnia bisctosa occurs abundantly along the edge of the water, but its larva has not been found. The brackish water back from the lake has along its edges a beautiful new species of Tachytrechus.

I stopped off from morning until 5 P. M. at Promontory Point, almost in the middle of the lake, where I found essentially the same beach fauna as near Salt Lake City, adding Rhicnoessa coronata. The wife of the station agent kindly provided me with dinner, as there is no hotel. The same afternoon I continued across the lake to Lakeside on the west shore, where again the beach fauna is about the same. It is a sidetrack with a few railroad employees, the surrounding country an absolute desert. The main divide between the ancient lake basin of Utah and that of Nevada is a little east of Wells, Nevada, which was the point I selected for my next stop, having been informed that it was on the bank of a river. I had to inquire in the town, after a vain search, whether there was any water near, and was informed that there was a little seepage about a mile below town. It was 2 P. M. 
when I got off the train, and I had already lost an hour, so I made what haste I could in the hot sun to the place indicated, where I found in a small space more new and interesting Diptera than I ever collected in the same time before. Within two hours the following and many more common species were obtained: Anacampta latiuscula and two new species; Dolichopus ciliatus, ammicola, obcordatus and five undescribed species; Sphegina n. sp., Euparyphus n. sp., Asyndetus n. sp., Calobata pallipes, Palloptera jucunda, Diaphorus palpiger and opacus, Hydrophorus sodalis and magdalcnae, Lispa tentaculata and uliginosa, and some not yet fully determined. In accordance with my plans, I continued my journey at ten that evening, but there are some very attractive-looking high mountains a few miles south of Wells that had timber and snow upon them, which would in my opinion be one of the best collecting fields in the West.

Hazen, Nevada, was reached the next morning. A good hotel is the principal feature of the place, which consists principally of a few railroad employees. The Soda Lakes are about ten miles south, being some two miles from Mirage siding, on the Fallons branch. They are small bodies of very alkaline water, where quite a business was done in the manufacture of soda until the seepage from the new irrigating canals of the Truckee-Carson government irrigation project raised the level above the evaporating beds and put a stop to the enterprise. I stayed over night with the caretaker at the works and collected at the shore of the lakes Ephydra hians and Caenia bisetosa, as at Great Salt Lake. A single male of Hydrophorus plumbeus Ald. was found also, known previously only from a single female from Soap Lake, Washington. Around fresh or brackish seepage I found another new species of Dolichopus, Hydrophorus aestuum and gratiosus, Pelastoneurus cyaneus, Thrypticus fraterculus, and Melieria occidentalis. Chrysops discalis was occasionally present.

On July I4 I made a visit to Reno and called upon Professor S. B. Doten, whom I found much engrossed with his interesting investigation of the habits of Hymenopterous parasites, for which he has invented several ingenious pieces of apparatus; his devices for instantaneous photography under 
the microscope are especially warthy of commendation. A short stroll around the outskirts of the town yielded Thrypticus fraterculus, Chrysomysa demandata, Asemosyrphus mexicanuls, Madisa (Desmometopa) halteralis and some commoner things.

The next day I returned eastward to Wadsworth and took the stage 20 miles north to the Nevada Indian School, where the superintendent, Mr. J. D. Oliver, provided me with accommodations and I remained four days. The trip in was highly interesting to me, as I discovered a really garrulous Indian in the driver "Fat Joe," and we struck up a warm friendship. The school is four miles from Pyramid Lake and eight from Winnemucca Lake, both of which I visited. They are moderately alkaline, but contain large quantities of fish. There is a more alkaline pond a mile south of Pyramid Lake, but it was difficult to reach, as it was on the other side of the Truckee River and the water was high; so I did not visit it. The bottoms of the Truckee River are verdant in this desert region and offer some good insects. The shore of Pyramid yielded a few Lispas of an undescribed species, as well as Ephydra hians; at Winnemucca I found still another undescribed Lispa with several common species of the genus. Among the Diptera collected on my trips to and from the lakes and about the Indian school were Chrysops discalis and coloradensis, Tabanus opacus, Exoprosopa ercmita, Anthrax agrippina, nugator, lepidota, Ceria tridcus, Tachytrechus angustipennis, Thrypticus fraterculus, Hydrophorus gratiosus and philombrius, Geomy a frontalis, Rhicnoessa albula, Urellia abstersa and Cacnia bisetosa.

On July ig I returned to Wadsworth and took the train to Hazen, where I took the Goldfield train next morning to the little freighting station of Thorne, close to the south end of Walker Lake. An automobile conveys the passengers seven miles across a very sandy desert to the county seat town of Hawthorne, occupying a little oasis less than half a mile square. After dinner another auto stage runs before suppertime to Bodie, California, climbing over the IValker Lake mountain range, crossing a valley and ascending almost exactly to the summit of the next range, Bodie having an ele- 
vation of 8400 feet. The road was good and our speedometer indicated 35 miles an hour on one down grade stretch, with seven passengers and a heavy load of mail, express and baggage. Bodie is an old, decayed mining camp with a few hundred inhabitants. Next morning a horse stage driven by a Mexican took me to one of my main objective points, Mono Lake, a distance of 22 miles. I stopped at the Mono Lake post-office and secured accommodations for a few days at the combined store, saloon, hotel, blacksmith shop and feed mill of Jack Hammond, about a mile beyond. Here I devoted my first attention to the insects of the lake itself. It is a highly alkaline body of water and contains vast numbers of the larvae of Ephydra hians, used in the pupa stage as food by the Indians under the name of "koo-tsabe." The specific identity of the fly had not been ascertained prior to my visit. Along the west side of the lake the shores rise abruptly into the Sierras, and there are numbers of rapid streams, large and small. The collecting is superb, and I could have spent more time to good advantage, but my plans limited me to four days. Besides some new species, the following are the more interesting results of my collecting: Bittacomorpha sackeni, Tabanus opacus and phaenops, Thereva johnsoni, Tachytrechus olympiae and angustipennis, Nothosympycmus vegetus, Psilopodinus pilicornis, Sympycmus marcidus, Chrysogaster nigrozittata, Clausicella setigera, Notonaula.x cincta and Themira putris.

Mono Lake lies close against the east side of the main Sierras, directly east of Yosemite Park, which comes up to the divide, about 16 miles by trail from the lake. Parties not infrequently come down to the lake from the Park; in fact it is more visited from that side than from the railroad some 65 miles away to the eastward. When I was there the Sierras towering above it were covered with great fields of snow and I never saw a more picturesque view than the one looking down on the lake and across it to the mountains, from the range near Bodie.

On my return to the railroad I had to stay over night at Thorne, in order to have time to box up some freight for shipment. The hotel business mostly goes to Hawthorne, but I felt well repaid for any little inconvenience of my stay in 
Thorne in making the acquaintance of "Doc" Stewart, mine host at the Old Crow,-an old-timer of the sixties, whose warm-hearted interest in me is a pleasant memory.

From Thorne I continued my journey to Southern California by an unusual route, as it was necessary to include Owen's Lake in the itinerary. I continued down the Goldfield railroad to Mina, where I changed to a narrow-gauge line that ends at Keeler, on the east side of Owen's Lake. I left this line at Owenyo, where it is joined by a Southern Pacific broad gauge branch that strikes the main line at Mojave, from which it is easy to reach Los Angeles.

We reached Owenyo about midnight, several hours behind time, and were accommodated in a box car hotel, the single men occupying hard bunks in an undivided car. Next morning the mixed train on the branch took me as far down as Olancha, which I had been informed would be a good point from which to inspect the west shore of the lake. It proved to be about five miles beyond the lake, so I put in most of the day collecting along a beautiful little mountain stream coming out of the Sierras and around some seepage near the lake. Diptera of interest were Pelastoneurus dissimilipes, Tachytrechus auratus and Rhagoletis minuta. Many insects of other orders occupied my attention and would be well worth recording if they had been identified. That evening I took the up train again to get to a point near the lake, and (accepting advice again) stopped off at Brier siding at ro P. M., only to find that the ranch supposed to be there was at another siding and there was not a human being within miles except the Mexican boy who had driven down from the Los Angeles aqueduct camp to pick up any Slavs who might have drifted in to work on the ditch. The boy took me up to the camp and let me sleep on a few sacks on the ground. Next morning I secured breakfast with the laborers and walked to the lake, where I made what observations were necessary in time to leave again on the southbound train. The lake is densely alkaline and is full of the larvae of Ephydra hians.

The evening of this day found me in Los Angeles and the remainder of the trip may be passed over in a few paragraphs. In Los Angeles I collected carefully about the ponds of crude 
petroleum in the oil well district for Psilopa petrolei; although I could not find the larva in the petroleum, I succeeded in getting the adults on grass around the pools. In the same locality was Pelastoneurus dissimilipes.

On the beach at Santa Monica were many specimens of a new species of Stichopogon, and on the surface of a brackish pool close to the beach was a swarm of Ephydra millbrae.

On the beach at Long Beach Lipochacta slossonae was abundant.

At Lake Elsinore, an alkaline lake south of Riverside, I captured the same beautiful new species of Tachytrechus that I got at the south end of Great Salt Lake; also a single specimen of a new species of Lispa, of which I later secured a pair at fresh water at Lewiston. Idaho. Cacnia bisetosa was the most abundant insect at the shore.

On the salt marsh adjacent to Palo Alto I collected several specimens of a species of Canace, a very peculiar sort of Ephydrid; also Hercostomus metatarsalis, Pelastoneurus cyaneus and Hydrophorus aestuum.

A two days' trip of a strenuous sort was made to Clear Lake, Lake County, Cal., from San Francisco, to ascertain what sort of Ephydra it was of which the larva had been named E. californica by Packard many years ago. As the lake is fresh water, and not salt as Packard had been informed, it was evident that the larvae came from some other water. I found that two borax ponds near the lake were well known, and made a visit to one of these, where I speedily found $E$. hians, which seemed to settle the identity of Packard's species. I also found the same large, undescribed Lispa which accompanied hians on the shores of Great Salt Lake.

The papers which I have published on the results of the trip are the following:

I. Larvae of a Saturniid Moth Used as Food by California Indians. Jour. N. Y. Ent. Soc., xx, I-4, I pl.: Mar., Igr 2.

2. Flies of the Leptid Genus Atherix Used as Food by California Indians. Ent. News, xxiii, I50-I63: Apr., I9I2.

3. The Biology of Some Western Species of the Dipterous Genus Ephydra. Jour. N. Y. Ent. Soc., xx, 77-09, 3 pl.; June, I9I2.

4. Two VVestern Species of Ephydra. Ibid., Ioo-Io3; June, I9I2.

5. The North American Species of the Dipterous Genus Lispa. Jour. N. Y. Ent. Soc., in press. 
[Reprinted from Journal of the New York Entomological Society, Vol. XXI, No. 2, June, I9I3.]

\title{
THE NORTH AMERICAN SPECIES OF LISPA (DIPTERA; ANTHOMYIDE). ${ }^{1}$
}

\author{
By J. M. Aldrich, \\ Moscow, IDAHo.
}

While the Anthomyidæ in general have justly acquired the reputation of being very difficult to classify, and at the same time highly uninteresting, there are a few groups that are not only easily recognized, but also of considerable scientific interest. If these were better known, it might take the curse off the family; fuller knowledge would inevitably create more interest, and with a few entomologists the family might become even a favorite. Hence it is very desirable that such genera as are susceptible of easy definition be worked out, as a beginning.

${ }^{1}$ This paper is one of the results of an investigation of western salt and alkaline lakes, carried on with the aid of an appropriation from the Elizabeth Thompson Fund. 
The genus Lispa is one of these easily recognized ones. It belongs to the second section of the family, having the front broad in the male as well as in the female, and in this section differing from all its congeners in having in both sexes great dilated palpi, generally somewhat spoon-shaped, and either black or yellow in color. The species are found at the edge of water, and occur in abundance throughout the season everywhere in the United States; two or three species can be found in any neighborhood. Nothing definite is known about the larval habits, but by elimination it would appear that they must occur in the mud in the immediate vicinity of the adults. The commonest species are about the size, shape and color of a house-fly.

The known North American species agree closely in most of their characters, which are given below at some length to avoid repetition in the specific descriptions.

Gencric Characters.-Front broad in both sexes, with a row of about 6 orbital bristles, the upper two curving backward or nearly erect, the rest curving toward the middle line; orbits hairy between the eye and these bristles; no hairs or bristles on the front between the ocelli and the antennæ; a large pair of ocellar bristles and numerous hairs between and behind the ocelli. Antenna not very long, arista thickened at base, plumose. Face concave, epistoma projecting, with large vibrissæ and some smaller bristles, which continue back along the sides of the mouth cavity (in palposa the males and some females without vibrissæ, or these indistinguishable from the other bristles); facial orbits with small hairs, which in some species are continuous with those of the frontal orbits; head somewhat protuberant at the insertion of the antenne, often with a contrasting black velvety transverse band turned up at the ends, across the base of the antennx. Palpi greatly dilated at tip, either suddenly or gradually, more or less bare and glistening on the expanded portion. Proboscis short, small, horny, labella of medium size. Back of head protuberant, hairy; vertical bristles 2 pairs as usual; one pair of small post-verticals, occiput bare.

Thorax somewhat narrow and elongate, with the following chrtotaxy: dorsocentrals 5,3 behind the suture (nasoni has 6,4 behind the suture): acrostichal merely hairs; notopleural 2; presutural I; posthumeral (intrahumeral) I ; humeral 2 or more; supra-alar I intraalar 2; postalar 2; scutellar 2 (pairs); prothoracic (above the front 
coxæ) I or more; mesopleural $I$ in front near the protothoracic and a vertical row on hind edge; sternopleural 3 ( $\mathrm{I}$ in front and 2 behind). Calypters (tegulæ, squamæ) rather large, conspicuous, the hind one about twice as long as the other. Abdomen cylindrical, straight or convex, or moderately depressed, often with spots of yellow or white pollen on the last two segments; segments hairy, the hairs longer on the hind edge of the segment and especially on the sides, on the fourth and fifth these long hairs becoming bristle-like; hypopygium never very large. Legs hairy and bristly; the principal bristles of the front ones as follows; coxæ on fore side with numerous bristles not in rows except on outer edge; femora with a double row on upper and outer edge, and a single row on lower and outer edge; tibiæ with about three preapical bristles and sometimes one higher up, below the middle. Middle legs: coxæ hairy or bristly on foreside, femora sometimes elongate and then more slender on apical third, with one or more preapical bristles on the hind side above; tibia with one or two bristles on the outer side about the middle. Hind legs: femora with a row of bristles above, and another less complete on the lower and outer side; tibix with one or two bristles near the middle and several preapical.

Wings of simple structure, third and fourth veins parallel (convergent in some old-world species); no noticeable spots or clouds; anterior crossvein almost behind the tip of first vein; posterior crossvein distant less than its length from the margin (on the fifth vein).

The first comprehensive treatment of the North American species was by Stein, in his important paper on N. A. Anthomyidæ (Berl. Ent. Zeitsch., XLII, I6I-288, I897) ; he described three new species (nigromaculata subsequently proving to be a synonym of palposa), and identified three others. Starting from this basis, the student may consult two important papers on the European and palrearctic fauna respectively;-Kowarz, Wien. Ent. Ztg., XI, 33-54, I892; and Becker, Zeitsch. f. Ent., XXIX, I-70, I904.

My study of the North American species indicates that the available characters for specific separation are few but sufficient. Head characters are the width of the front at the narrowest as compared with the entire width of the head, the measurement being in both cases at the level of the antennæ or even a trifle below, where the compound eyes are nearest together. The presence and coarseness of hairs on the sides of the face; presence of a black band across root 
of antennæ; presence and size of the vibrissæ; and the shape, size and color of the palpi, are characters of importance. In the thorax and wings few specific variations occur in North American species, at least of a tangible kind. The legs are quite rich in characters when closely studied; three of the species show secondary sexual characters here, only one of which was known heretofore. The length of the hind tarsi of the males in comparison with their tibia is generally important, and the number and arrangement of the spines on the under side of the hind femora are very useful. The abdomen differs in form from cylindrical to depressed, and is variously marked with gray or white pollen. I have made no particular use of the hypopygium, although I do not doubt that it has a variety of forms quite distinctive when it is extirpated so as to be available for study, in the method of Schnabl and Dziedzicki.

The following table summarizes the data I collected from measurements of the species. The columns contain the following data:

Column I, the quotient obtained by dividing the entire horizontal transverse diameter of the head by the distance separating the eyes at the point of greatest approximation (about the level of the antennæ), in the male sex.

Column 2, the same for the female sex.

Column 3 , the quotient obtained by dividing the length of the hind tibia by the length of the hind tarsus, in the male sex.

\begin{tabular}{|c|c|c|c|}
\hline Species. & $\mathbf{I}$ & 2 & 3 \\
\hline albitarsis.... & 3.85 & 2.74 & .94 \\
\hline antennata................. & 2.06 & 1.92 & $\begin{array}{r}.95 \\
1.47\end{array}$ \\
\hline 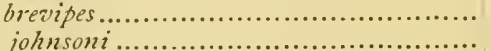 & $\begin{array}{l}2.90 \\
3.71^{1}\end{array}$ & $\overline{2.2 I}$ & $\begin{array}{l}1.47 \\
1.64\end{array}$ \\
\hline 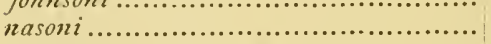 & 3.10 & $2.5 I$ & I.06 \\
\hline 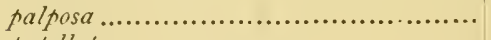 & 2.62 & 2.50 & I. 37 \\
\hline 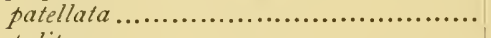 & 2.70 & - & I.OS \\
\hline polita........................................ & 2.62 & 2.33 & 1.04 \\
\hline salina.......................................... & 2.44 & 2.06 & 1.00 \\
\hline spinipes ....................................... & 3.22 & 3.02 & 1.70 \\
\hline sociabilis...................................... & 2.86 & 2.50 & 1.27 \\
\hline 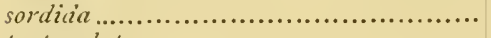 & 3.21 & 2.42 & 1. 39 \\
\hline 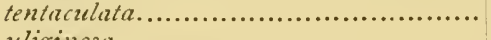 & 2.89 & 2.33 & 1.03 \\
\hline uliginosa..................................... & 2.80 & 2.47 & .98 \\
\hline
\end{tabular}

${ }^{1}$ The only male of jolnsoni is teneral, the head somewhat shrunken, and this number is undoubtedly too large. 
The following figures will give an idea of the degree of constancy of the characters:

Five males of salina gave the following numbers for column I$2.39,2.45,2.44,2.42,2.50$. Average, 2.44; range, .I I.

Eight males of tentaculata gave $3.00,2.95,2.76,2.77,2.72,2.70$, $2.74,2.89$. Average 2.82 ; range, .30.

Four males of uliginosa gave 2.77, 2.72, 2.89, 2.83. Average, 2.80; range, .17 .

Four females of nasoni gave the following for column 2-2.40, 2.58, 2.50, 2.54. Average, 2.5I ; range, .IS.

Three females of tentaculata gave 2.33, 2.34, 2.33. Average, 2.33; range, .OI.

Four females of salina gave 2.00, 2.I I, 2.06, 2.4I. The last showed the character of the male in the front, and I re-examined it carefully. It was the only case of the kind that occurred, and as it appeared abnormal I excluded it from the average, which would then be 2.06 , with a range of .II.

The following species mentioned in my Catalogue are not included herein; for the reasons given:

consanguinca. The dark tibiæ are not decisive, as made out by Stein, and there is no evidence that the species as now accepted occurs in North America.

flavicincta. Not seen by Stein, and probably not North American. hispida. Unrecognizable, and type not found by Stein in the British Museum.

nigromaculata. A synonym of palposa, but the fact was accidentally omitted in the Catalogue (Stein, Zeitsch. f. Hym. u. Dipt., I90r, 203, 209).

rufitibialis. Probably recognizable, but not known from the mainland of North America, and not seen by me.

scrotina. I cannot make out any tangible characters.

The following species is added (mentioned in the appendix to the Catalogue, in the 1904 literature):

polita Coquillett, Invertebrata Pacifica, I, 34--Ormsby Co., Nevada.

The bibliography since I904 is mostly unimportant, consisting of notices of the occurrence of some of the widespread species in new 
localities; it is therefore not mentioned herein except where something of special interest is brought out.

\section{TABle of Species of LISPA.}

Males.

I. Fifth abdominal segment black, with a chalk-white central spot above,

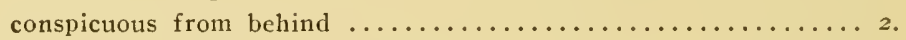
Fifth abdominal segment not so marked ....................

2. Second joint of middle tarsus shorter than the third ....sordida $\mathrm{n}$. sp.

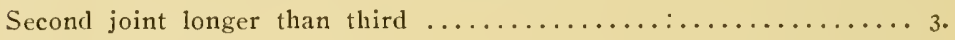

3. Palpi black, vibrissæe wanting ................ palposa Walker.

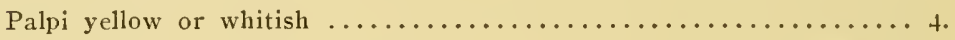

4. Hind tarsus as long as its tibia $\ldots \ldots \ldots \ldots \ldots \ldots \ldots \ldots$ salina n. sp.

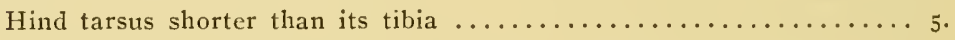

5. Fourth joint of middle tarsus prolonged in a slender spine as long as the

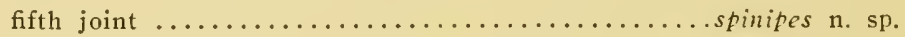

Fourth joint not with spine; with unusually long hairs between and out-

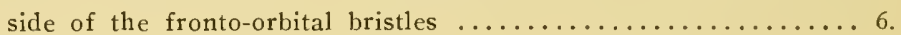

6. Vibrissæ delicate, hardly distinguishable; sides of face bare above

Vibrissæ normal, sides of face above with rather coarse hairs

brevipes $\mathrm{n}$. sp. johnsoni $\mathrm{n}$. sp.

7. Front metatarsus with a prolongation beside the following joint ...8 8 . Front metatarsus without such prolongation $\ldots \ldots \ldots \ldots \ldots \ldots \ldots$.

8. First two joints of front tarsi reddish; the second more than twice as long as the body of the first ..............tentaculata De Geer. Second joint hardly longer than the first ............ patellata $\mathrm{n} . \mathrm{sp}$.

9. Front tarsus elongated (its first two joints as long as its tibia), pale in the middle, last point enlarged, triangular, black ... albitarsis Stein. Front tarsus of ordinary form, about as long as tibia .......... 10.

10. With four post-sutural dorso-centrals ............. nasoni Stein.

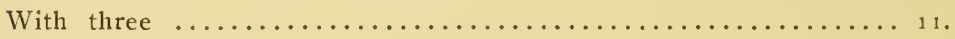

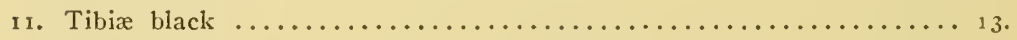

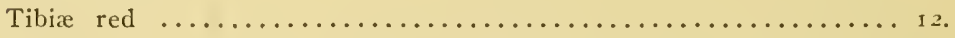

I2. Abdomen with a pair of large, shining black, sub-confluent spots on each of segments 2, 3, and 4; antennæ long, front narrowed below

uliginosa Fallen.

Abdomen pruinose, with only faint traces of spots; antennæ shorter, front not narrowed below ........................ antennata n. sp.

13. With distinct white spots on the $4^{\text {th }}$ and $5^{\text {th }}$ abdominal segments

sociabilis Loew.

Without such spots polita Coquillett. 
Females.

I. With four post-sutural dorso-centrals ............. nasoni Stein.

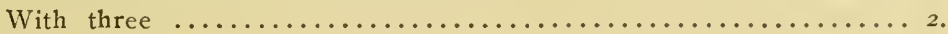

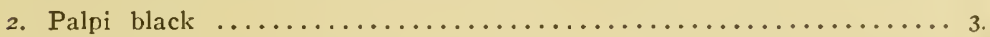

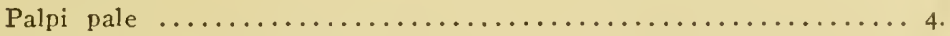

3. With a heavy velvet-black band from eye to eye across the root of the

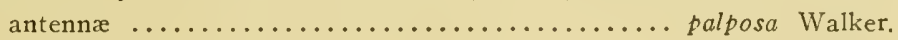
With a faint band or none ..................... sordida $\mathrm{n}$. sp.

4. Abdomen wholly shining black ............... polita Coquillett.

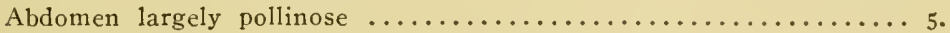

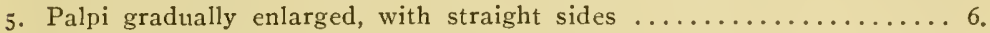

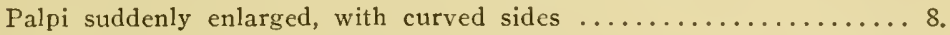

6. Sides of face narrow and with a few fine hairs ....... albitarsis Stein. Sides of face wide and with numerous coarse hairs ............ 7 .

7. Abdomen with two large, shining black areas on each of segments 2,3 ,

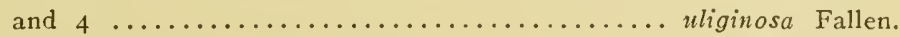
Abdomen almost wholly gray pollinose ............... antennata n. sp.

8. Third and fourth abdominal segments with a white pollinose spot (rarely yellow) on each side, the middle shining black or with a pollinose spot behind ....................... tentaculata De Geer.

sociabilis Loew. patellata n. sp.

Third and fourth abdominal segments rather uniformly grayish pollinose 9.

9. Front at antennæ narrower than either eye ........... spinipes n. sp. Front at antennæ wider than one eye $\ldots \ldots \ldots \ldots \ldots \ldots \ldots \ldots . .$. ro. Bristles of under side of hind femora much larger beyond the middle salina n. sp.

Bristles of the under side of hind femora equally large on the basal half johnsoni n. sp.

\section{Lispa sordida new species.}

Male.-Head 3.2 I times the width of the front at narrowest place; ocellar triangle yellow pollinose, frontal orbits gray, the rest of the front dull black; antennæ wholly black, third joint small, $1 \frac{1 / 2}{2}$ tinles as long as second, arista short, with thin long plumosity; sides of face silvery, with only a few hairs on the lower part; middle of face brownish-yellow pollinose; vibrissæ of moderate size, surrounded with only a few sniall hairs; palpi dark brown to black, occasionally reddish-brown, dilated rather suddenly to a medium size for the genus; the outer side of the dilated portion seems in the normal position to show as a white pollinose spot from in front. Occiput brownish pollinose.

Mesonotum half-shining or less, the pollen gray or brownish; one pair of small prescutellar bristles, the hairs of the scutellum long; halteres yellow with brown knob; calypters ivory-white with faint yellow border.

Abdomen narrow, a little flattened, with gray pollen, which in some specimens becomes brownish on the sides; the second segment has a subshining 
spot each side on the posterior half; on the third the same parts are more shining; the posterior half of the fourth is shining, but narrowed at the sides; the third segment has appressed narginal macrochætæ, the fourth has about 4 discal and 8 marginal ones, not appressed; the posterior edge of the fourth sternite stands out from the body, is very hairy, and has a notch in the middle, as well as several bristles; fifth tergite moderately prominent, hairy and bristly, velvet-black, with a chalk-white median dorsal spot extending the whole length and about one-third the width. Organs of the hypopygium closely folded in, not distinguishable.

Legs entirely black, knees not appreciably lighter; front legs plain, the tarsal joints of regularly decreasing length; middle femora rather long, a little attenuated at tip, with two or three excessively long hair-like bristles on the front side at base and a few shorter, but still long ones on the under side at base; middle tibir long, with one bristle on the front outer side and two on the hind outer side, before the preapical; middle tarsus with a shortened second joint, which in specimens is generally bent at an angle with the first and third,-it is of normal structure, shorter than the third and about the same length as the fourth; hind femora rather slender, the under bristles strong, hind tibix with two small bristles near the middle; hind tarsi short, their tibiæ 1.39 times their length, first joint as long as all the others, which taper off and end in unusually small claws and no pulvilli.

Wings faintly brownish, veins brown. Length $6 \mathrm{~mm}$; of wing $5 \mathrm{~mm}$.

Female.-Front wider than in the male, the head 2.42 times its width; tarsi of plain structure, hind ones barely shorter than their tibix; abdomen generally less shining, sometimes with median blackish stripe, fifth segment with 6 or 8 discal macrochretr, fifth and sixth segments retracted, but with'a trace of white mark above. Length $8 \mathrm{~mm}$; ; of wing $6 \mathrm{~mm}$.

Numerous specimens of both sexes, collected at the edges of saline water (Box Elder Lake), Brigham City, Utah, July 4 and 5, I9I I.

\section{Lispa palposa Walker.}

Male.-Front nearly black (the head 2.62 times the front in width), upper part of the ocellar triangle brown, orbital margins narrowly yellowish, with a single row of hairs next to the eye; a very striking velvety black band from eye to eye at the level of the insertion of the antennæ and below; antennx black, the first two joints velvety, arista long-plumose; sides of face with a clear silvery sheen, bare except low down; middle of face concolorous; vibrissæ hardly distinguishable from the small bristles of the sides of the mouth; palpi velvcty black, suddenly enlarged about the middle, with long black hairs on the front and lower edge; proboscis black, of ordinary form; the usual erect small bristles of the back of the head arranged somewhat in rows.

Thorax black in ground color, gray pruinose, with the beginnings of four black stripes in front, the median two more distinct and extending farther back; chetotaxy normal; calypteres ivory-white with brown border; halteres yellow with brown knob. 
Abdomen rather depressed for a $\delta$, black, almost shining, with the following parts light gray pruinose; a broad anterior spot on each side of the second and third segments, connecting with a broad central portion extending the whole length of the segment; on the fourth segment the lateral spots are even larger and sometimes brown pruinose, while the central spot is small and indistinct, so that the middle is shining black in front; fifth segment velvety black, with a triangular pure white pruinose spot above, very conspicuous. Venter blackish gray, with long bristles on the first segment. Bristles of the sides of the abdomen rather abundant, appressed on the second and third segments, erect and dense on the first, fourth segment with about three discal on each side and a row of marginal slightly interrupted in the middle; fifth with rather delicate but numerous bristles.

Wings subhyaline, of normal form.

Legs black with thin whitish pruinosity; knees hardly at all lighter; middle femora a little slender toward the apex, tibix with a pair of bristles on the outer side just below the middle; hind femora below with a row of about 9 bristles, becoming long and slender past the middle, and a single bristle on the hind and outer side below the middle of the tibia; the tibia has also rather long hairs on the outer side; hind tarsi considerably shorter than their tibix (tibia 1.37 times the tarsus), the first joint almost as long as the other four. Length $6 \mathrm{~mm}$.

Female.-Head about 2.50 times the front in width, but varying somewhat; face with a few scattering hairs on the sides; vibrissæ generally well developed. Abdomen more flattened, the median gray areas of the second and third segments wider and more diffuse and with a slender longitudinal line in the middle. Hind tarsus longer, almost equaling its tibia, the first joint considerably shorter than the following four. Length $6.6 \mathrm{~mm}$.

In both sexes the front is not at all narrowed below. The abdominal coloration as usual is sometimes not quite so well developed as described above.

Many specimens: Lawrence, Kans.; Brookings, Elmira and Pierre, S. D.; Cache Junction, Utah; Moscow and Elk River, Ida.; Hood River, Ore. Some of the specimens are cotypes of Stein's nigromaculata.

\section{Lispa salina new species.}

A large, hairy, gray species, with yellow palpi and a conspicuous white spot on the tip of the abdomen in the male.

Male.-Head 2.44 times front in width; front brown, this color running to a point near the antennæ between two black patches which fade into brown above; around and behind the ocellar triangle are numerous small hairs; the upper two pairs of orbital bristles divergent, the remainder, about 6 pairs, decussate; a row of proclinate hairs on the orbit outside the bristles; viewed 
from below, the lower projecting edge of the front is black from the insertion of the antenna obliquely upward to the eye. Antennæ velvet black, third joint hardly twice as long as the second and more slender than it, arista thickened on the basal third and with about a dozen long hairs, none originating beyond the middle. Sides of face silvery above on the outside of the ptilinal suture, the rest brassy, hairy outside the suture from the middle of the silvery part to about the lower corner of the eye. Palpi rather dark yellow, enlarging with moderate suddenness toward the tip, of medium size for the genus, hairy all over except a small space beyond the middle. Proboscis black, shining. Back of head convex, more so below, gray with bushy black hair, which is especially long on the oral margin; occiput with hairs above and a pair of post-vertical bristles, bare below these.

Thorax gray, with black hair almost all over, bristles as usual in the genus; pleuræ concolorous with dorsum, bare behind the front and middle coxx and in front of the prothoracic spiracle. Calypters wax-white with yellow border. Halteres with brown knob, stem yellow.

Abdomen robust, gray all over the first fonr segments, slightly yellowish above, with long hair; along the sides some macrochætæ are hardly distinguishable from the large hairs; 4th segment with a terminal circle of machrochretæ and a discal row that is interrupted in the middle; 5 th segment velvet black, hairy, with a conspicuons median dorsal chalk-white spot.

Legs very hairy, gray throughout, the tarsi more blackish with pale yellow pubescence below, pulvilli pale yellow. Front legs: coxæ with a row of strong bristles on anterior side; femora with a double row of bristles on upper outer side and a single row on lower; middle femora with two preapical bristles; middle tibix with two bristles near the middle; hind femora with the usual rows of long bristles and besides them numerous very long hairs below on the basal two thirds; hind tibia exactly equal to their tarsi in length, with one bristle near the middle. All the tarsi have the basal joint shorter than the other four combined, the latter of approximately equal length in each tarsus.

Wing subhyaline, veins yellowish toward the base, $3 \mathrm{~d}$ and $4^{\text {th }}$ veins not convergent.

Female.-Head about 2.06 times front in width; abdomen with a dark median line (sometimes faintly visible on the basal segments in the $\sigma^{2}$ ), and sub-shining blackish lateral spots on the hind margin of the second and third segments; the median stripe is usually widened on the anterior part of the second and again on the third segment; 4th segment entirely sub-shining blackish; 5 th segment minute, black. No long pile on under side of hind femora. Length, $\delta$, 5.5-7.2 $\mathrm{mm}$. ; $9,6.5-9.5 \mathrm{~mm}$.

Many specimens of both sexes: South end of Great Salt Lake, Utah, July 3I, I908 and July 9, I9I I ; Pyramid Lake, Nevada, July I6, I9I I Walker Lake, Nevada, July 25, I9I I B Borax Lake in Lake Co., California, August 8, I9I I. 
I sent some of this material to Mr. Theodor Becker, Liegnitz, Prussia, in 1908, as he had recentlv published a revision of the palæarctic species of Lispa; he informed me that he could not distinguish this species from one which he had described as $L$. cinifcra, from Siberia. Since then I have referred it to that species until very lately, when I have come to the conclusion that it is different. Cinifera is known in only a single $\delta^{\lambda}$ specimen, not very well preserved, and a complete conparison cannot be made. The description of cinifcra states that the hind metatarsus is longer than all four of the following joints, a rather striking character which does not apply to salina; the long pile of the under side of the hind femur is not mentioned in the description of cinifcra, but is conspicuous in salina. These with some slighter discrepancies, together with the wide difference of locality, lead me to believe that it would be dangerous to accept the view that cinifora includes our American form.

This is a very characteristic fly of the shores of the denser salt and alkaline lakes of the West. Although I did not find the larvæ, they will probably be found under the beach refuse, which in the case of Great Salt Lake consists almost entirely of the puparia of Ephydra gracilis Pack.

\section{Lispa spinipes new species.}

A smallish gray species with narrow front and face, the short 4th joint of the middle tarsus in the $\delta$ ending in a long slender appressed spine, which reaches to the tip of the slender 5 th joint.

Nale-Front much narrower than either eye (the head 3.22 times its width), hardly narrowed toward the antennæ; face narrow, especially the sides, which have only a single row of small hairs, none above the 111iddle; the whole face pale yellow, more whitish at the edges; vibrissæ very small; antennæ wholly black, of ordinary form: palpi yellow, of moderate size for the genus and widening to the apical part with about the usual suddenness, with a few black hairs except on the middle of the dilated part.

Thorax wholly gray, with the usual chrtotaxy; halteres yellow with brownish knob, calypters white with faint yellow margin.

Abdomen gray, no median stripe, sides of second and third segments very faintly darker behind, fourth segment changing to yellowish; fifth segment black, almost all the dorsal half pure white; hypopygium inconspicuous, black.

Legs uniformly gray except the knees and a little of the base of each tibia, which are yellowish red; pulvilli rather small, brownish; front tibire with only subapical bristles, their tarsi longer than the tibix; middle femora slender toward tip; middle tibix with two smallish bristles just beyond the middle; middle tarsi considerably shorter than their tibiæ, the second, third and 
fourth joints all short, the fourth ending in a spine which continues along the fifth joint to the claws; fifth joint attached to the fourth at one side before the tip, much longer and more slender than usual. Hind tibix with a row of small bristles down the hind side, one of wlich beyond the middle is of uncommon length. All the femora are rather slender. Hind tibiæ 1.70 times as long as their tarsi.

Wings of ordinary structure, hind crossvein not much more than half its length from the margin, straight and moderately inclined. Length $5.5 \mathrm{~mm}$.; of wing $3.8 \mathrm{~mm}$.

One $\sigma^{\lambda}$, collected by me at Lake Elsinore, California, on August 2, I9II. One $\delta^{\lambda}$, one $q$, Lewiston, Ida., Aug. 2, I9I2. The female is rather teneral and the head and front width cannot be accurately determined; the front is evidently narrow however. The middle tarsi are of simple structure.

Lake Elsinore is a moderately alkaline body of water; but spinipes it appears is found also in fresh water, as at Lewiston, Idaho; in this respect it is unlike sordida, salina and antcmnata, which have been found so far only at alkaline or salt water.

\section{Lispa brevipes new species.}

Male.-Eyes nearest together at the level of the antennx, where they are separated by considerably less than the width of one eye (head 2.9 times the width of the front); front blackish anteriorly, brown above, the acuminate brown ocellar triangle indistinct toward the antennæ; frontal orbits with long hairs between and outside the bristles; a heavy black band connects the eyes across the base of the antennæe, slightly up-turned at the eyes, just as in palposa; antennæ velvety black on first two joints, the second not with paler apical margin, third joint as usual; sides of face silvery, without hairs except a few on lower part; middle of face brassy; vibrissæ decidedly less developed than in most species, with numerous hairs on the outer side of each; palpi brownish-yellow, not quite so large nor so suddenly dilated as in tentaculata, moderately hairy. Thorax on the dorsum grayish, sub-shining, a paler pruinose median stripe, which disappears posteriorly and has a faint brown stripe upon it; the beginning of another gray stripe each side at the front end of the dorsocentral rows; humeri gray; chætotaxy normal; halteres with brown knob, calypter ivory-white with yellow border; wings normal. Abdomen rather flat and wide, the first four segments alnost uniform light-gray dusted, fifth segment black, with a conspicuous chalk-white, almost silvery triangular median dorsal spot; fourth segment with discal and apical row of bristles; venter unicolorous, a little darker than dorsum, fourth sternite with a deep, rounded incision. Legs including the knees entirely black, with uniform gray pruinosity; front tarsi of almost the length of their tibix, the first joint fully as long as all the rest; middle tarsi about three fourths as long as their tibix, slender; hind tibia 1.47 times as long as its tarsus, the basal 
joint of the tarsus somewhat thickened, about equal to the following four, the second longer than the third. Front tibia without a bristle at the middle; middle femur slender beyond the middle, the bristles on the basal part rather long and slender; middle tibia with two bristles below the middle; hind femur not very stout, with long slender bristles in the row beneath, the tibia with long hairs on the outer side and one bristle below the middle. Length $6 \mathrm{~mm}$.

One male, Moscow, Idaho, August 6, I912. The female has not been discovered.

In this species the band across the base of the antennæ resembles palposa, and the rather dark palpi and faint vibrissæ tend in the same direction but to a less degree. The absence of pattern on the abdomen shows more of a likeness to johnsoni, which however has fully developed vibrissa.

\section{Lispa johnsoni new species.}

Male.-The only male specimen is somewhat teneral, and the front part of the head is shrunken, making a full description difficult. The front appears to be much as in brevipes, and there are indications of the black band across the base of the antennx; the hairs between the fronto-orbitals and outside them are long and coarse; the sides of the front have hairs almost up to these but not so large, although well developed for the location; vibrissæ of full size, and a row of good-sized bristles extending back from them along the epistoma; antennæ in the specimen teneral and shrunken, not showing any unusual features. Palpi dark yellow, slightly brownish, of full size for the genus, rather suddenly enlarged, hairy all over except a small space near the distal edge of the disk. Thorax gray, sub-opaque, very indistinctly striped, or with faint indications of stripes, the bristles strong; a small prescutcllar pair is present, otherwise the chrtotaxy is normal; halteres with a brown knob; calypters ivory-white with yellow margin; wing normal. Abdomen not flattened, near the base having a section like an equilateral triangle with the corners rounded, almost unicolorous gray, with a slender abbreviated median blackish stripe and on the lower part of the side in the third and fourth segments a trace of a dark triangle; fifth segment black with a distinct chalkwhite median dorsal spot. Fourth segment with irregularly placed bristles on the sides of the disk, and a marginal row. Legs wholly black, including knees, gray dusted; femora rather stout and hairy; front tarsi fully as long as their tibiæ, the first joint almost as long as the following four; middle tibia with two spines considerably below the middle; hind tibia with one stout bristle below the middle, I.64 times the length of the tarsus, first joint of the tarsus not quite so long as all the rest; the hind femur has on the lower edge the usual row of about ten slender hairlike bristles.

Female.-In good condition. Head 2.20 times as wide as front, the latter with a velvet black band sharply defined on its lower border; first two joints of antennæ velvet black; sides of face rather coarsely hairy all the way up 
to the front; vibrissæ strong; palpi as in the male. Thorax gray with two well-defined narrow blackish stripes destitute of hairs inside of the dorsocentrals, not continuing much back of the suture; outside the dorsocentrals a less distinct stripe. Abdomen gray with a black median stripe extending to the fourth segment. Hind tarsus as long as the tibia. Length, $6.8 \mathrm{~mm}$.

One male, two females, Cohasset, Mass., Sept. 9, collected by C. W. Johnson.

This species is rather closely allied to salina, but in the male has the hind tarsi shortened and the hind femora destitute of the very long, almost woolly hairs of that species; in the female the palpi are larger, darker, and more hairy than in salina.

The difference between johnsoni and the Central Asian cinifera is not easy to state, as in each the male is known only from a rather poorly preserved specimen; they are closely allied.

\section{Lispa tentaculata De Geer.}

Male.-Head 2.89 times the width of front, the latter narrowed somewhat strongly below, the sides convex; the narrowest point is below the insertion of the antenni, and is about the same as the width of one eye at the widest point (looking from straight in front); color of front black, indistinctly brown on the ocellar triangle and narrowly forward from it, the orbits becoming gradually yellow about the middle, which color continues down the side of the face without interruption; the fine hairs of the frontal orbit continue without interruption down the side of the face; antennæ black, second joint faintly and narrowly yellowish at apex, third reaching nearly to the single bristle above the vibrissa, arista rather long plumose; face including its sides golden yellow pruinose, the sides with a few fine hairs which extend almost to the lower edge of the eye; vibrissæ strong, with some smaller bristles which are more numerous and slender posteriorly; palpi very large, shining pale yellow, suddenly enlarged about the middle, the apical broad part with scattered black hairs.

Thorax black in ground color, grayish pruinose, sub-shining with a median vitta abbreviated in front and two less distinct lateral vittæ along the dorsocentrals, at the extreme front two black vittæ begin between these, but fade away in a short distance. Chrtotaxy normal; calypteres ivory white, with yellow margins; halteres dark yellow. A tuft of small black bristles arises from just behind the metathoracic spiracle.

Wings entirely normal for the genus.

Abdomen very broad and flat; the first segment grayish pruinose; the second segment with white pruinosity anteriorly on the sides, which changes to yellowish and extends mesially and posteriorly so as to leave three areas shining black-the hind part on each side and the middle part in front; third segment with a large definite white pruinose spot on each side against the front border, and a median yellowish brown pruinose spot on the hind margin, 
the rest shining; fourth segment with a still larger white pruinose spot on each side against the front border, the rest shining; fifth segment wholly shining black, but little visible. Venter grayish white. Bristles of abdomen not of noticeable size except on the fourth and fifth segments.

Legs and pleuræ covered with plumbeous pruinosity; knees yellow; front tarsi of very characteristic structure, longer than their tibix, the first joint short, usually yellow, with a tuft of black bristles below, and prolonged in a yellow process along the side of the second joint, the process one half longer than the first joint itself, and with a black tip; second joint yellow, about half as long as the tibia; remaining joints becoming darker, longer than in most species. Middle femora rather slender and blackish toward the apex, with only short hairs and bristles, their tibiæ with a single bristle on the outer side at the middle, their tarsi slender and long, a little pale at base; hind femora with long, slender bristles or hairs below in a sparse row beginning before the middle, the tibix with about three irregularly spaced bristles on the hind side and soft, long hair on the inner side; hind tibia r.03 times the tarsus, first joint of the latter with a brush of hair below, not much over half as loug as the four following. Length $5.5 \mathrm{~mm}$.

Female.-Head 2.35 times the front in width; front tarsus black, the first joint of ordinary form, nearly twice as long as the second, the whole tarsus about $I \frac{1}{2}$ times the length of the tibia, hind tarsus a little longer than its tibia; the hind femur generally has a single long, hairlike bristle on the under side beyond the middle (occasionally two). Palpi not quite so shining, but nearly as large as in the $\delta$. Length $7 \mathrm{~mm}$.

This is the most abundant species; Becker reports it everywhere common in Europe around fresh water, also from the Canary Islands and Central Asia. I have it in abundance from South Dakota, Kansas, Idaho, Utah, Nevada, Oregon and Washington, and it has been recorded from New England and California. It is seldom sought in vain at the edge of fresh water during the entire collecting season, in my experience.

Sociabilis and patcllata are very closely related to this species; the differences I have summarized under their respective descriptions.

\section{Lispa patellata new species.}

Male.-Head 2.70 times the width of front, the latter widening very slightly above, blackish including the middle and upper parts of the orbits; the last with fine hairs which continue uniformly down the sides of the face; entire face including sides brown pollinose, no band across root of antennæ; antennæ black, second joint at tip with a white pollinose roundish spot when viewed diagonally from below; arista rather thin pilose; vibrissæ large, with smaller bristles extending back under the head; palpi of immense size, glistening white, slightly flesh-colored, as wide as the full length of the antenna and the enlarged part nearly a half longer, suddenly widened downward from the 
stalk-like portion, with only a few hairs, which are on the lower edge and the inner side. Thorax narrow, slightly brownish-black, not with noticeable vittæ; hairs and bristles well developed, chætotaxy normal; pleura changing color to a somewhat glaucous below; calypters white, with pale yellow border; halteres yellowish; wings of ordinary structure, the veins brownish toward the base. Abdomen considerably flattened, oval in outline; second, third and fourth segments with successively larger white pollinose triangles on the sides, middle of second and third segments with an indistinct yellowish pollinose spot; otherwise the abdomen becoming more shining black toward the tip; fifth segment black, showing very little from above; bristles of abdomen not very large. Legs wholly black except the first and second joints of the front tarsus, which are more or less reddish,- the first short, with a process extending along the outer side of the second, nearly as long as the first and two thirds as long as the second, the following joints of the front tarsus black and somewhat flattened; middle and hind femora moderately elongated and slender, the latter with two or three slender bristles below beyond the middle; middle tibia with a small bristle on the hind side at the middle, hind tibia with a bristle on outer side at the middle, r.08 times as long as its tarsus. Length $6 \mathrm{~mm}$.

Female.-I am unable to indicate any satisfactory character on which to separate the $q$ from that of tentaculata.

Seven males: Boulder, Colo.; Moscow, Kendrick, Peck, Juliaetta and Potlatch, Idaho. Dates in Idaho are April I8, June II, I 8 and 28, and September Io. Two females collected at Boulder, which may be this species ( $I$ got no males of tentaculata while collecting there), have reddish middle and hind tibiæ, comparatively small palpi, and brown dust on the thorax.

The type locality is Moscow.

\section{Lispa albitarsis Stein.}

Male--Front narrow, especially below (head 3.85 times the width of the front, the narrowest front in the genus); the usual acuminate frontal triangle very indistinct; sides of face very narrow, with a few hairs all the way up; whole face light brassy yellow; antennæ black, third joint rather long, arista brownish-yellow, loosely plumose; second joint with indistinct brownishyellow band at apex; vibrissa large and stout, on the outer side of each a few coarse hairs curving downward; cheek very narrow below the eye; palpi yellow, gradually expanded from the base, the widest part narrower than in any other species found in North America, equal to about one third the length of the third joint of the antenna. Thorax rather narrow, glaucous on the anterior half with three brown stripes, which become indistinct on the more shining portion behind the middle. Coxæ and femora black, the front coxæ silvery in front, with few bristles; front tibia black; front tarsus elongated, once and a third the length of the tibia (tibia is .74 the length of the tarsus); 
first joint long and slender, pale at tip; second and third joints of medium and equal length, slender, yellowish-white; fourth and fifth joints flattened, black, the claws large and divergent; pulvilli enlarged, snow-white; middle tibia and tarsus rather dark brown than black, the former with a large bristle below the middle on the front side, and a smaller one above it on the hind side; hind tibia yellowish-brown, darker toward the base, with only two bristles before the apical ones,--these two are on the outer side; the hind tibia is .94 times the length of the hind tarsus; the latter dark brown; the hind femur has two large bristles on the under side, before the middle. Wings ordinary, calypters white with pale margin, halteres yellow. Abdomen depressed, mostly shining black above, but with a white pollinose transverse spot on the hind edge at each side on segments 1,2 , and 3 , which rums over a trifle upon the front edge of the succeeding segment; also one large bristle on each side of segments 2 and 3 , and on the fourth segment a terminal circle of six and a sub-basal lateral pair; hypopygium small and retracted. Length $4 \mathrm{mmll}$.

Femalc.-Head 2.74 times the width of the front; frontal triangle as usual; thoracic stripes not distinct; front tarsi hardly longer than tibix, plain, the tibix brownish-yellow at base; hind femur with only one moderate bristle below; middle tibix brownish, the hind ones reddish-brown, near the base with a darker ring. Length, 5.1 $\mathrm{mm}$.

Two males and one female, from the type lot: Lawrence, Kans., Tifton, Ga., Opelousas, La.

\section{A somewhat aberrant species, very well marked.}

\section{Lispa nasoni Stein.}

Male.-Front wide above, considerably narrowed at the antennæ, where the eyes have enlarged facets; head about 3.10 times the narrowest width of front; orbits yellowish pollinose; face rapidly widening below, wholly silvery with a yellowish tinge, the sides with small scattering hairs meeting those of the frontal orbit, antennæ deep black, a distinct red band at tip of second joint, third joint somewhat elongated; cheek below eye rather wide; palpi yellow, gradually widened from the base, the greatest width only about half the length of the third antennal joint, with a few black hairs except on the disk. Thorax cinereous, with a fairly distinct median brown stripe extending to the tip of the scutellum, a less distinct lateral stripe each side, and some indications of another outside this, mostly behind the suture; four dorsocentrals behind the suture, the anterior two of then smaller than the posterior two; halteres yellow; calypters white, border very pale. Legs black, the femora rather broadly at tip, and all the tibix, yellow. Front coxæ with only about ten bristles on the front side,--less than in most species; middle tibia with a medium bristle on the outer front side about the middle, and a small one opposite it on the outer hind side; hind tibia 1.06 times the length of its tarsus, with a medium bristle below the middle on the outer side; hind femur with a short row of only three bristles on the outer side below, ending 
about the middle, and generally a single bristle in place of the inner row. Abdomen cinereous, with a pair of shining black spots on each of the first four segments, the first pair small and indistinct; the median cinereous line is of the same color and texture as the rest of the cinereous surface (in uliginosa generally delicate and indistinct); fourth segment from a third to a half the length of the third; fifth segment rounded, with an inverted V-shaped notch below. Wings of ordinary structure. Length, $5 \mathrm{~mm}$.

Female.-Head and front wider, the proportion about 2.51 ; hind femora below with only one bristle. Length $6 \mathrm{~mm}$.

Eleven specimens of both sexes, six of them from the typical material determined by Stein; South Dakota; Louisiana and Georgia (Hough); Redwood City and Lake Elsinore, Cal.; Winnemucca and Pyramid Lakes, Nev.; Roswell, Ida.; Havana, Cuba (C. F. Baker). One male has on the hind femur four bristles in the outer row below and three in the inner.

The species is most related to uliginosa, from which it differs in the number of dorso-central bristles, and in the $\delta$ by having a shorter abdomen, fewer and more delicate hairs on the sides of the face, dorsum more distinctly striped, narrower face, and fewer bristles on lower side of hind femora.

\section{Lispa uliginosa Fallen.}

Male.-Head 2.80 times as wide as front, the latter wide above, narrowing appreciably toward the antennæ, with the usual long, narrow frontal triangle; margins a little silvery below the middle; compound eyes with a distinct area of enlarged facets about the level of the antennæ; antennæ of usual form, black, the second joint with a transverse yellow band at tip, which looks whitish in certain lights; face including its sides and the anterior part of the cheeks yellowish-gray, with a somewhat silvery reflection; sides of face with a few hairs extending up to the front, at the level of the vibrissæ these are quite strong; palpi pale yellow, gradually enlarged almost from the base, not very wide in the widest place-hardly half as wide as the length of the third antennal joint-with a rounded bare spot in the widest place, elsewhere with coarse black hairs. Thorax only moderately pollinose, halfshining, with strong bristles arranged as usual; halteres yellow, calypters white with pale yellowish border. Legs black, except extreme apices of the femora and all the tibix, which are yellow; tarsi entirely black; middle tibia with a long bristle on the front side well below the middle, and a small one on the hind side at the middle; hind tibia .98 times the length of its tarsus, with one bristle on the outer front side below the middle, and a row on the outer hind side, of which the one at the middle is largest; hind femora with two rows of stiff, rather short bristles below, and the usual strong row above. Abdomen long and almost cylindrical, the fourth segment hardly half as long 
as the third; fifth protruding in almost hemispherical form, the first four segments have each a large shining black spot on the dorsum, interrupted by a rather indistinct median gray pruinose line; on the second and third segments these spots are triangular, narrowing forward almost to a point, while behind they are almost as wide as the dorsum; along the side of the second and third segments there is an indistinct brown streak; remainder of abdomen ashy-gray pollinose, the hairs arising from brown dots. Wings as usual. Length, $6 \mathrm{~mm}$.

Female.-Head about 2.47 times as wide as front; sides of face considerably wider and more hairy, otherwise all the characters of the male are found, even the enlarged facets; in the place of the two rows of bristles on the lower side of the hind femur there is only a single bristle or sometimes two. Length, $7 \mathrm{~mm}$.

A common and widespread species, occurring in Europe and throughout the United States. Specimens are in my collection from Buffalo, N. Y. (M. C. Van Duzee) ; Algonquin, Ill. (Nason) ; Brookings, S. D.; and a number of places in Idaho, Utah, Nevada, California and Washington. It is on record from St. Vincent, IV. I.; Mexico; Florida, Ontario, etc.

\section{Lispa antennata new species.}

A slender species with opaque abdomen, wide sides of face and cheeks, and second antennal joint tipped with reddish-yellow.

Male.-Head 2.06 times as wide as front, the latter very little narrowed at the antennæ, frontal orbits narrow, more distinctly yellow anteriorly; antennæ black, second joint at tip narrowly reddish-yellow, which changes to whitish when viewed from below, third joint short, arista with long plumosity; face wholly grayish-white pollinose, wide above and rapidly becoming still wider below on account of the triangular form of the facialia, which are nearly as wide at the level of the vibrissæ as the sides of the face are; the hairs of the frontal orbits continue down on the sides of the face or facial orbits to about the level of the vibrissæ, but are scattering on the upper part; a single large vibrissa with three or four small bristles in a row laterad across the lower end of the facialium; palpi light yellow, with a rather sudden enlargement, covered with scattering black hairs except on the outer side in front, where there is a bare, glistening whitish spot.

Thorax cinereous, with no dark longitudinal lines except at the very front edge; chætotaxy normal, bristles well developed; pleuræ concolorous; halteres yellow; calypteres ivory-white.

Abdomen cylindrical, cinereous, second and third segments each with a dull blackish spot on each side, rather faint (on the first segment still fainter), fourth segment capable of a good deal of retraction and generally exposed for a much shorter length than the preceding ones; fifth segment very narrow and visible only for a small space dorsally; hypopygiun of moderate size, con- 
colorous with rest of abdomen; third and fourth segments with a row of marginal bristles, first and second with irregularly placed bristles along the sides; third segment with a V cut out beneath where the sternite would be.

Femora black, robust, tibix rather dark yellow, tarsi yellow, infuscated toward the tip, with large yellowish pulvilli. Front tibia with a bristle beyond the middle on the outer side, and one on the front side a little lower down; front tarsi plain; middle femora with a row of bristles on the front side that extends only to the middle, and two preapical bristles on the hind side; middle tibia with a bristle on the outer hind side just beyond the middle and another on the outer front side a little lower down; hind femora with the usual three rows of bristles; hind tibia .98 times the length of its tarsus, with a bristle below the middle on the hind side, above this a row of two to four small bristles, and below it on the outer side a small bristle.

Wings of ordinary structure, the veins yellowish. Length $7.3 \mathrm{~mm}$.; of wing $5.2 \mathrm{~mm}$.

Female.-Head 1.92 times the front in width; sides of face wider and more hairy; palpi not so suddenly enlarged, but about as wide; a faint brown line in the middle of the thoracic dorsum; a single bristle on the under and outer side of the hind femur, representing the row that occurs in the $\sigma^{\lambda}$; hind tibia. Length $7.4 \mathrm{~mm}$; 年 wing $5.8 \mathrm{~mm}$.

Fifteen specimens, of both sexes, collected at Pyramid Lake, Utah, along the shore at the south end, July i6, I9I I.

\section{Lispa sociabilis Loew.}

Centuries, ii, 72 .

Male.-Almost like patellata, but with the following differences: head 2.86 times front in width; palpi less widened, but still very large, about as wide as the length of the third antennal joint, while in patellata they are fully as wide as the length of both second and third; color as in patellata, almost white, glistening, and with few hairs. Front tarsi with first joint yellow, on the outer side with only an insignificant point where the prolongation occurs in patellata and tentaculata; second joint yellow, sometimes blackened from the middle, about three fourths as long as the first joint, the remaining joints of nearly equal length, black, somewhat flattened; all knees and extreme tips of tibiæ yellow; middle and hind tarsi yellow on under side at least to tip of first joint; hind femur generally destitute of slender hairlike bristles on under side beyond the middle, occasionally with only one; middle tibia without bristle near middle. Hind tibia 1.27 times as long as its tarsus.

Female.-Head about 2.50 times the front in width, but somewhat variable; palpi nearly as in the $\hat{\sigma}$; front metatarsus nearly as long as the three following joints, blackish; middle tibia with one bristle near middle; hind femur with one bristle below, beyond the middle (absent in one out of four) ; tibiæ almost entirely black. Length of $\delta^{\lambda}, 6 \mathrm{~mm}$.

Seven J's, four O's, Trenton, Lucaston and Iona, N. J.; Mont- 
gomery Co., Pa.; Jackson, Miss. Dates, May I6 and 26, Aug. II, I5 and 2I, Sept., II, Oct. 5 and 30.

The three species, patcllata, tentaculata, and sociabilis, form a group in which the males are separated mainly but readily on secondary sexual characters, while the females offer almost no tangible differences. The group has the tessellated pattern better developed on the abdomen than in the rest of our species, and about equally in both sexes.

\section{Lispa polita Coquillett.}

Coquillett, Invertebrata Pacifica, i, 34--Ormsby Co., Nev.

Harbeck, Entomological News, xx, 46, oc. in N. J.

Male.-Wholly black, the only yellow ground color being in the palpi and $\mathrm{a}$ band across the apex of the second joint of the antenna; head 2.62 times the width of front, the latter wide, rather golden along the orbits below; antenna ordinary: face wide, sordid yellowish white, the sides with fine, sparse hairs, coarser next the vibrissa; palpi yellow, the basal part whitish, widened gradually from the base, the widest part a little over half as wide as the length of the third antennal joint, with a round, shining space thereon. Thorax sub-shining, with a delicate brownish pruinosity, especially around the humeri; bristles strong, arranged as usual. Abdomen almost cylindrical, shining black, with only the most delicate brown pruinosity; fourth segment one third as long as the third; fifth segment hemispherical; bristles rather strong on the sides and near the apex. Femora all a little thickened, the hind ones with two rows of rather short, strong bristles below; middle tibia with a bristle on the front side below the middle and one on the hind side at the middle; hind tibia r.04 times as long as its tarsus, with one bristle on the outer front side below the middle, and a strikingly long one opposite it in the row on the hind side. Halteres dark yellow, calypters yellowish with brownish-yellow margin. Wings rather infuscated, the base brownish. Length, $7 \mathrm{~mm}$.

Female.-Head 2.33 times as wide as front; sides of face wider and with more numerous hairs; hind femur with only three or four bristles below; abdomen more oval, not so cylindrical, but very shining; femora hardly thickened; calypters paler. Length $6.6 \mathrm{~mm}$.

Two males, Moscow, Idaho, Aug. 23, and Viola, Ida. (only 8 miles from Moscow), Aug. $2 \mathrm{I}$; one female from the type lot, Ormsby Co., Nevada, collected by C. F. Baker and lent me by C. WV. Johnson. As shown above, it has been reported from New Jersey.

The structural characters of the species resemble those of uliginosa, but the shining black color is very distinctive. The abdomen of the male is longer than that of the female, giving a greater total length in the few cases examined. 



THE

\section{DIPTEROUS FAMILY}

\section{HELOMYZID AE}

BY

J. M. ALDRICH AND P. S. DARLINGTON

(PLATES III-IV)

[Reprint from the Transactions American Entomological Society, Vol. XXXIV, 1908.] 



\title{
THE IDPTEROUS FAMILY HELOMYZIDA.
}

\author{
BI J. M. ALDRICH AND P. S. DARLINGTON.
}

(Plates III-IV.)

[ҮotE.-This family of flies was taken up for study and revision by Mr. Darlington while a senior student in the University of Idaho. At the time of his graduation in June, $190 \%$, he bad nearly finished most of the genera, including the drawing up of descriptions of the species, new and old. At this time his appointment as horticultural inspector in an important field at Wenatchee, Wash., necessitated his immediate departure. As we had assumed obligations on all sicles by borrowing material, there was no course open to me but to complete the work, which after sone delay I have done. Ms part, aside from a general review, has been to work up the genera Leria and Siligo, and to prepare the illustrations. The new genus Siligo and its two species, and the new species of of Leria (glanca), shouid be credited to me; the other new genus, Porsenus, and the remaining new species, six in number, shonld be credited to Mr. Darlington, whose industry and keen discrimination left little for me to do as far as his time permitted him to go.-J. M. ALDrich.]

This small family of Acalyptrate Muscidæ is readily distinguished by the following characters: wings with auxiliary vein and second basal cell distinct, and a row of spines along the costa; vibrisse present; fronto-orbital bristles only one or two; all the tibire with preapical bristles.

Czerny, from a slightly different view point, defines the same group as follows: "The Helomyzidæ belong to that series of groups of Acalyptratre which possess convergent or erossed (also called decussate) postrertical bristles. They are distinguished from all the other groups of this series by the simultanenus occurrence of vibrissa and an entirely separate auxiliary vein." The postvertical bristles are located on the back of the head, somewhat behind the ocelli, and are easily seen.

For practical purposes the costal spines are almost sufficient to distinguish the family, but these do occur in a few species outside the family, especially in Cyrtonotum, Cania and Fucellia, of our fanna. Cyrtonotum (PI. IV, figs. 8, 9) has a short first longitudinal vein, united towards the tip with the auxiliary; Coniu has the typical Ephydrid face, and the second basal cell united with the discal; while Fucellia has a row of fronto-orbital bristles extending to the base of the antenuæ, some six in number. 
The costal spines in Heteromyza are said to be very small, but there seems to be no good reason for regarding this as a North American genus, and we have not taken it into account.

The larval habits are known in only a few eases in our fauna. Some of the species are found in caverns, where the larva are said to breed in the excrement of bats. The adults of others are found about the mouths of holes occupied by rodents; other species are adapted to life on sand dunes. The known hahits are mentioned under the separate species.

The classic paper on the family is Loew's "Ueber die europäischen Helomyzidæe und die in Schlesien vorkommenden Arten derselben," published in the Zeitschrift für Entomologie, xiii, 1-80. The work bears the date 1859, but as determined by Osten Sacken and Czerny it must have been published in 1862 or early in 1863 . There appear to be no names of about that period conflicting with Loew's, hence the exact date is not of great importance. Schiner's treatment of the family in Fauna Austriaca, Diptera, ii, 20-35, 1864 , really antedates in its preparation the paper by Loew ; hence it is practically superseded by the latter, especially in the matter of genera. The only other general work on the family is a recent one by Czerny, "Revision der Helomyziden," in Wiener Entomologische Zeitung, xxiii, 199-244 and 263-286, published in 1904. This includes the Helomyzinæ (only the genera Helomyza and Allophyla), being Part I of a work as yet unfinished. The descriptions of the American species are quoted; one useful feature of the work is al set of notes on Walker's types of Helomyzidæ, showing that none of the species belong to the fanily at all, unless it may be among the small number of which the types are now missing. Nearly all are Sapromyzas.

Lnew based his classification mainly on characters derived from the bristles; hence this was the first fanily in which chrtotaxy was used, and that long before the introduction of the term.

The bristles which by their variability afford generic characters are first of all the dorso-centrals, which occur in all the numbers from one to five; the humeral and propleural (either one each or absent) are also useful. The figure on Plate III shows the position of the various parts and bristles of the thorax.

Important specific characters are found in the number of sternopleural bristles, the presence or absence of hair or bristles on the 


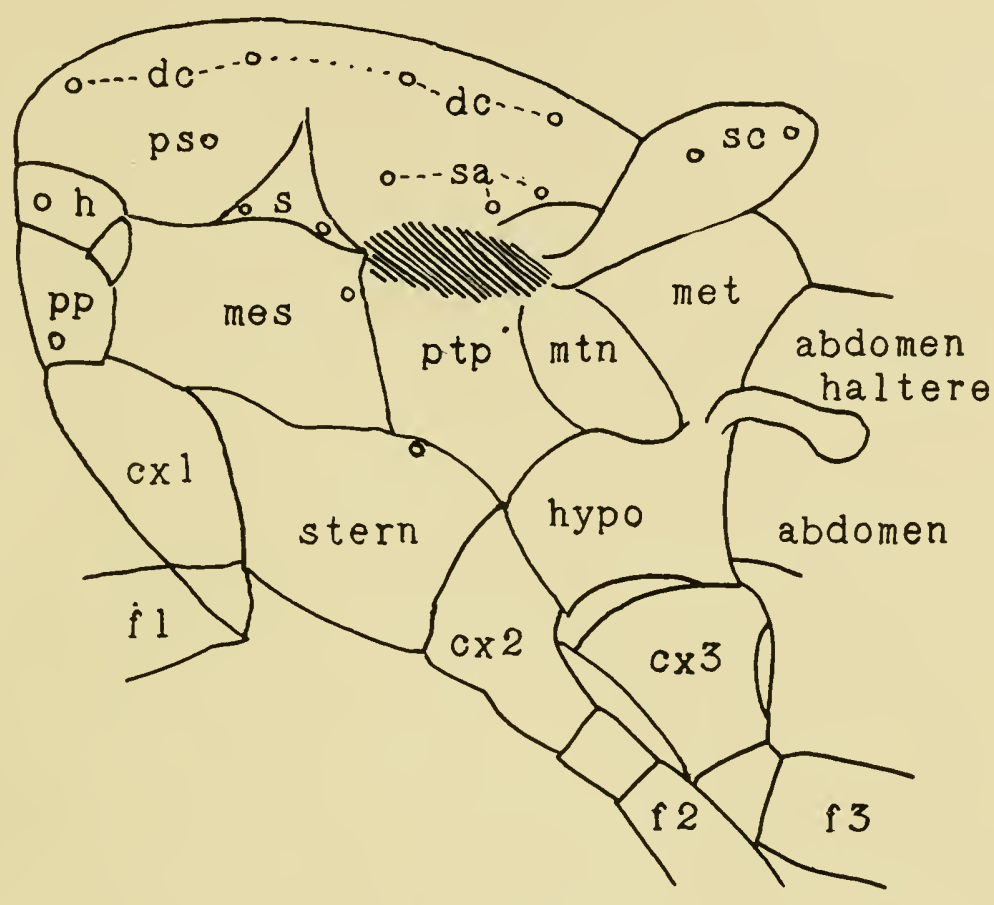

EXPLANATION.

dc, dorsocentral bristles, four in a row.

$\mathrm{h}$, humerus, with one bristle.

$\mathrm{s}$, the widened lateral end of the transverse suture, which is obsolete in the middle of the dorsum; the two notopleural bristles are located so that the $\mathrm{s}$ is between them.

ps, the presutural bristles.

sa, the three supra-alar bristles.

sc, the scutellum with the two scutellar bristles, apical and lateral.

mes, mesoternum, with one mesosternal bristle at the posterior edge.

stern, steruopleura, with one bristle at the upper edge.

pp, propleura, with one bristle on the lower part.

ptp, pteropleura.

mtn, metasternum.

hypo, hy posternum.

met, metanotum.

cx1, cх2, cх3, coxr.

$\mathrm{fl}$, f2, f3, femora.

The shaded area is the insertion of the wing. 

mesopleura, the size of the second fronto-orbital, the pubescence of the scutellum, etc. The constancy of some of the most minute of these characters is interesting.

Our work is based primarily on the collections of the senior author, in which the types, unless otherwise mentioned, will be retained. Important additional material was received from Prof. A. L. Melander, Pullman, Wash.; C. T. Brues, Milwaukee, Wris.; C. Wr. Johnson, Boston, Mass.; Erich Daecke, Philarlelphia, Pa.; and the United States National Museum. A few specimens came from Prof. R. A. Cooley, Bozeman, Montana; E. S. Tucker, Lawrence, Kansas; and C. F. Baker, now of Para, Brazil, but in California at the time of making these collections.

We have cited literature only when the same is not found in the 1905 Catalogue, except when changes of syuonymy, etc., are involved. The rest may be found in the Catalogue.

A side view of the thorax of Anorostoma maculata, somewhat diagrammatic, to show the sclerites and bristles, the origin of the latter represented by small circles, is given on Plate III.

TABLE OF GENERA.

1. Thorax with long pile, dorsocentrals but little differentiated.

Leria heIvola male.

Thorax with shorter pile, dorsocentrals well developed..............

2. One dorsocentral.................................

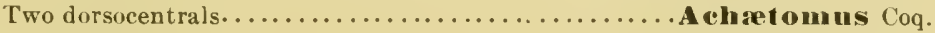

Three dorsocentrais................... Tephrochlamys Loew.

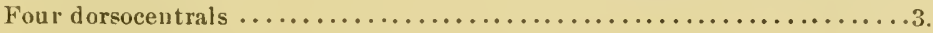

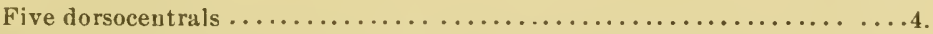

3. Middle tibiæ with spines on the outer side near the middle.

Ecothea Haliday.

Eyes very small, with vertical diameter less than the cheeks (Pl. IV, fig. 3).

Ecroptomera Loew.

Face very receding, convex in profile, witbout distinct oral margin (Pl. IV, fig. 4) ....................... nomostomin Loew.

Without the above characters $\ldots \ldots \ldots \ldots \ldots \ldots \ldots \ldots$ Lerian Loew.

4. Humeral bristle absent $\ldots \ldots \ldots \ldots \ldots \ldots \ldots \ldots \ldots \ldots$ HeIonyza Fall.

Humeral bristle present . . . . . . . . . . . . . . . . . . . . . . . .

5. No bristle on mesopleura .................... Mlophyla Loew.

A bristle on posterior part of mesopleura .................

PORSENUS Darlington, n. gen.

Humeral and propleural bristles absent; only one dorsocentral (the hindmost); only one supra-alar (the foremost); presutural 1 ; notopleural 2; scutellar a very large apical pair and a small lateral 
pair; prescutellar a small pair; fronto-orbital only one, very small; no sternopleural; one pteropleural.

Third joint of the antenna rounded, rather large, with long, bare arista; face receding, oral margin but little prominent, about as in Anorostoma.

Wing of ordinary Helomyzid form, costal spines distinct.

The name is firm Porsena, one of the invaders of Rome; we change the ending to avoid the confusion of a masculine nonn with a feminine ending. Accent on the first syllable.

The singular chætotaxy renders the species and genus easily recognizable, as there are half a dozen good generic characters. The head of the single type was accidentally rlestroyed after it had been drawn and some uotes marle, but a further examination in regard to the fronto-orbital bristles and the form of the oral margin would have given us a little greater certainty on these points.

Porsenus johusoui Darlington, n. sp. (Pl. IV, fig. 2).

Length, 4.7 unı.; of wing, $5.7 \mathrm{~mm}$.

General color ashy gray, with yellow legs.

Occiput gray; front brown; ẹes rather large, round; orbits silvery; cheeks about three-fonths the width of the eres, somewhat crean colored; first two joints of the antenua reddish, third cinereous, ronnd, arista rather long, only wicroscopically pubescent; one rather long vibrissa on each side.

Dorsun of thorax gray, the lateral edges a little yellowish, median part with coarse and rather dense hairs; mesopleura bare, except for two or three coarsc hairs on the front edge, just below the spincle; stemopleura densely pubescent alf over, with no bristle; pteroplenra with one good-sized bristle and several coarse hairs.

Abdomen gray, the posterior margin of each segment somewhat reddisl..

Wings with a faint brownish tinge, hind cross-vein slightly infurcated. The submarginal cell is rather noticeably widened in front of the anterior cross-vein.

Legs sellowish, with few bristles; femora indistinctly darker; tarsi moderately infuscated.

One female. Johnson: Boston, Mass., October 19th.

\section{A CH HTOMUN.}

Coquillett, Canad. Ent., xxxix, 75, Mareb, 1907.

"Near Helomyza, as restricted by Loew, but with only two pairs of dorsocentral bristles, propleural present, two pairs of frontoorbitals, etc. Eyes circular, cheeks nearly as wide as the eyeheight, third joint of antenns broader than long, arista dorsal, bare. Femora without bristles, tibire with apical and preapical hristles only. Venation as in Helomyza, spines of costa well-developerl. Type, the following species: 
- Achaecomus pilosus aw-pres. - Reddish brown, the scutellum and legs vellow, bases of aldominal segments three to five dark brown, hairs and bristles black. Hairs of cheeks covering their lower half, no bristles near vibrisse. Pleura almost wholly cuvered with hairs except the portion posterior to the sternoplenra, one sternopleural bristle, no other plenral bristles present; scutellum without hairs, four scutellar bristles. Wings hyaline, unmarked except the extreme base and the stigma, which ale yellowish. Length 8 m.

"North Saugus, Mass. A male specimen collected by. Mr. H. M. Russell. 'Type No. 10157, U. S. N. M." (Original deseription entire.)

Not represented in our material.

\section{'TEPIIROCHIAA MY' loew.}

Dorsocentral bristles 3 , all behind the suture; humeral 1 ; propleural 1 ; notopleural 2 ; supra-alar 3 ; scutellar 2 pairs; prescutellar 1 pair, moderately large; presutural 1; fronto-orbital 2. Third antennal joint a very little elongated, arista bare. Face moderately receding. Cheeks about half the width of the eye, with one or two bristles in the middle, at the end of the row of hairs descending behind the eye. Wings rather elongate and narrow, with small spines.

In Becker's part of the Katalog der Paläarktischen Dipteren, iv, 51 , the name is spelled Tephrochlamis; there appears to be no etymolngical reason why the original spelling with a $y$ should not be retainer.

\section{TABLE OF SPECIES.}

Scutellum wholls vellow ....................... flavitarsis n. $\mathrm{sp.}$ Scutellum mostly or wholly black in ground color..... rufiventris Meigen.

\section{Tephrochlamys favitarsis Darlington, u. sp.}

Length $6 \mathrm{~mm}$.; of wing $5.6 \mathrm{~mm}$.

Cheeks vellow; legs entirely sellow; wings brownish; scutellum entirely yellow.

Head brownish-yellow, occiput brown; front sellowish-brown; antennæ reddish-brown, third joint large, round; arista brown, bare; vibrissa one on each side, of medium length; also one bristle on the middle of each cheek.

Dorsum of the tborax gray on the middle part, somewhat reddish-gras on the lateral edges; two brown stripes run length wise between the dorso-central bristles; dorsum densely pubescent, except the lateral edges; scntellum entirely lemon-yellow, bare except the ordinary four bristles. Propleura and mesopleura brownish, bare except the one propleural bristle; sternopleura reddish-gray, with one strong bristle and a row of smaller hair on the upper edge.

Abdomen rellow, first segment gray. 
Wings with a brownish tinge; spines of the costa very short.

Legs entirely yellow.

One female specimen, U. S. N. MI., labelled "White Mts., Mor* rison."

\section{Tephrochlamys rufiventris Mejgen.}

Length $5.5 \mathrm{~mm}$.; of wing $6.2 \mathrm{~mm}$.

Gray; abdomen reddisb-yellow; cheeks whitish.

Oceiput ash-gray, frout saffron-rellow to brownish, pubescent; orbits of the eyes somewhat silvery-gray; antenne reddish-brown, the third joint nearly black, arista of medium length, bare; eyes rather large, ronnd; cheeks about three-fourths the width of the eye, somewhat crean color; vibrissa rather delicate, one on each side; at the middle of the hind edge of the bare part of the cheek is a smallish bristle.

Thorax entirely ash-gray; dorsum pubescent, except the lateral edges; the small hairs arise from small black dots, while the three pairs of dorso-central bristles arise from large black spots; seutellum gray, yellowish at the apex, bare except the ordinary four bristles.

Propleura bare, except the one strong bristle above the fore coxa; mesopleura bare, except one small hair on the lower anterior corner; on the upper edge of the sternopleura is one strong bristle and a row of smaller bairs.

Abdomen reddisb-yellow; the hypopygium of the male small; terninal segments in the female tapering, slender.

Wings hyaline except the stigma, which is brownish-yellow; veins dark brown, spines of the costa rather short.

Legs yellow, all the tarsi somewhat blackish, the outer side of the front fenur somewhat infuseated ; middle femur slender; hind femur rather stout; pulvilli inconspieuous.

Six males and thirty two females. Johnson, St. John's County, Quebec, June 5th; Boston, Mass., July 7th. U. S. N. M., Franconia, N. H. Daecke, Orange Mountains, N. J., July. Melander, Berkeley, Cal., March 26th; St. Johns, Quebec, September 23rd; Pullman, Wash., March 9th. Aldrich, Friday Harbor, Wash., May 28th; Moscow, Idaho, all seasons.

This species is very common at Moscow, Idaho, and can be found on windows at almost any time during the year.

Becker, Katalog, iv, 51, adopts Meigen's name canescens, published in his Systematische Beschreibung, vi, 57 , in preference to this, which was published on the following page. As there is no question that the two names refer to the same species, the only point at issue between the two is whether the strict observance of page precedence justifies the changing of a name that is in general use. In this case we are in entire accord with the rules of the International Congress in deciding against change. 
GECOTH A Haliday.

Dorsocentral bristles 4 ( 3 belind the suture); humeral 1 ; notopleural 2; presutural 1 ; propleural 1 ; supra-alar 3 ; scutellar 2 pairs, the apical divergent; prescutellar 0 or minute; fronto-orbital 1 ; on the midlle tibia near the middle one on the hind sirle and several on the front. Hear rather flattened in firont, short in fore and aft measurement; eyes smallish, round; cheeks about half or three-fifths as wide as the eye. Front very wide. Antennie rather large, third joint not quite round, with long, thin, bare arista. Oral margin prominent. No bristle on cheek. Scutellum elongate. Wings of the usual form, costal spines strong, the hind apical angle of the discal cell generally acute.

The spines on the niddle part of the middle tibia are the chief mark of generic distinction; they occur in no other genus of Heloinyzidæ.

We have but one species.

\section{Ecothea fenestralis Fallen.}

Blepharoptera specus Aldich, 21st Rept. Geol. Ind., 1896, 189.

Length $4.5 \mathrm{~mm}$; ; of wing, the same.

General color brown, legs and feet yellow.

- Front brown above, , yellowish toward the anteune, with rather coarse black hairs all over; face light sellow, the distinct antennal grooves darker; a single strong vibrissa on each side; palpi sellow; antennæ dark brown.

Thorax browu on the dorsum, the bumeri, entire seutellum, and edges of notum yellow; scutellum with coarse hairs on its dorsal surface; pleuræ largely yellow, the mesoplenra and sternopleura darker; mesopleura bare, sternoplenra with one bristle and scattered hairs; pteroplen ra bare; halteres yellow.

Abdomen darker brown, narrowly whitish on the hind edges of the segments, sixth segment and heyond yellow.

Legs wholly sellow, including coxe and tips of tarsi.

Wings rellowish, veins yellow, cross-veins darker but not distinctly bordered.

The specimen described is perhaps a little lighter in color than the average; there is considerable variation in the intensity and extent of the brown. The tarsi are sometimes infuscated toward the apex, and the scutellum is not always yellow at the base, etc.

Twelve specimens, both sexes. Aldrich: Brookings, S. Dakota ; Porter and Wyandotte Caves, Indiana. Johnson: Brookline, Mass. U. S. N. M. : Algonquin, Ill.

The Indiana cave specimens are cotypes of Blepharopterc specus Aldich. Blatchley adds a note to the original description as follows: "The species of Blepharopterie were the largest and most 
common Diptera noted in the eaves. They were found in the damper portions of nearly every cave visited, on the walls and roof: They were never noted on the wing, except when disturhed, when they would fly but a short distance before alighting." 'This refers to defessa, pubescens and latens, as well as the above species.

ECCOP'TOMEIRA Loew.

This genus, not hitherto reported from North America, but repre senter in Europe by some nine species, is separated from Leria primarily by the smallness of the eyes; the figure of our new speeies illustrates this character.

Chretotaxy: oue humeral, one proplenral, one fronto-orbital, four iorsocentral, no prescutellar, four scutellar, one presutural, two notopleural, three supra-alar. The middle femur has an irregular row of rather striking bristles on the front side (in our species). Arista always very long and thin. Antenne small, far apart, with small grooves below them, which are widely separated on the face. Posterior cross vein forming an acute angle with the fifth vein behind, but standing about at a right angle with the longitudinal axis of the wing.

Necoptomera americana Darlington, n. sp. (PI. IV, fig. 3 ) = simpacen Length $6.7 \mathrm{~mm}$; ; of wing $6.7 \mathrm{~mm}$.

Yellow, including all the tarsal and antenral joints; abdomen more or less blaekish.

Head sellow, two dark brown stripes runving from the base of the occiput to the vertex; a tuft of small hairs parted in the middle at the base of the occiput; frout somewhat saffron rellow, very slightly pubeseent; antennæ saffron rellow, the distal end of the second joint bordered with brown; third joint scarcely equaling in length the two preeeding taken together, not infuscated; arista long and slender, not pubescent; cheeks straw color, about one and one-fourth times the width of the ese; one strong vibrissa on each side, rather far apart.

Thoras sellow; dorsum with vers short and inconspicuons pubescence; dorsocentral bristles large and promiuent; scutellum sellow, witls sparse pubescence besides the usual four bristles; mesopleura bare except three or four vers small lrairs on the lower auteriur corner; stcruopleura with one strong bristle and one smaller hair on the upper edge, sparsely pubescent below.

Abdomen varying from yellow to blackish-rellow; the second, third and fourth segments usually with a blackish posterior border; hypopsgim sellow, of medium size.

Legs entirely yellow; pubescence very short and ineouspicuous; the frout femora armed with two rows of strong bristles, one on the upper edge and one on the lower; hind femora armed with some irregularly placed bristles.

'Three males, Moseow and Craig's Mt., Idaho (Aldrich). 


\section{A NOROSTCYI Loew.}

A humeral and a propleural bristle; three supra-alar; one presutural; two notopleural; one large and one small mesopleural bristle; four dorsocentual bristles; two fionto-orbital bristles. Eyes transversely ovate; cheeks broad; face receding, the front edge of the mouth entirely obliterated ( $i$. e. the lower part of the face is not set off from the oral cavity by a sharp margin). The sixth longitudinal vein extends to the margin of the wing. The distinct mesopleural bristle seems to be a valuable generic character.

\section{TABLE OF SPECIES.}

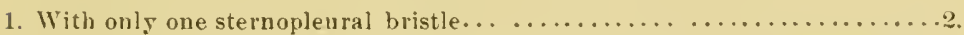

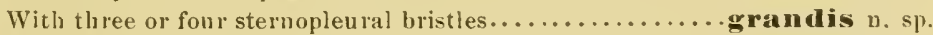

2. Wing with a black spot covering both cross-veins ............ parea Cog.

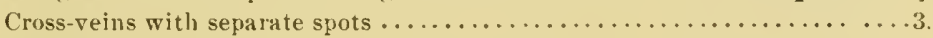

3. Tholax black in ground color, with gras dust......... manculata n. sp. Thorax yellow in ground color, with sellowish dust......marginata Lw.

\section{A norostoma grandis Darlington, n. sp.}

Length $7.3 \mathrm{~mm}$.; of wing, the same.

Iarge, blackish species, pulvilli long and conspicuous (in the male); hind femora exceptionalls stout.

Occiput and frout brownish; a black stripe extends from the ocellau bristles io the occiput; front densely pubescent below; cheeks straw rellow, about the width of the eye; exes transversely oval; antenna brownish, third joint oval; arista short, bare; face strongly receding below ; vibrissa one on each side, chuse together, rather delicate.

Thorax light brown; dorsum rather densely sprinkled with dark brown dots from which the small hairs arise, and with larger dark brown spots from which the bristles arise; scutellum reddish-brown, bare except the ordinary four bristles; besides the one propleural bristle a propleural hair; two bristles and a hair on the posterior margin of the mesopleura, which is otherwise bare; on the npper edge of the steruoplenra is a row of from three to four strong bristles (three on one side; on the other four, two of which are a little smaller); stemopleura pubescent below.

Abdomen black, hypopygium yellow. globose.

Wings alnost hyaline; the end of the auxiliary vein and the small and large cross-veins infuscated the clond on the small cuoss-vein is preceded and followid by whitish areas, and there is anotber of these on the cosia beyond the end of the auxiliary, also a few faint ones in the base of the wing.

Legs yellow; frout femora infuscated, niddle femora comparatively slender, hind ones exceptronally stout; the last with a black spot near the distal end : all the puivilli long and conspicuous, dirty white in color.

One male specimen. Aldrich: Pacific Grove, Cal., May 9th ; collected in a wet meadow in the woods near the seashore about a mile south of Pt. Pinos Light. 
A norostoma opaca Coquillett.

"Head yellow, opaque, white pruinose, the front and nper part of the occiput tinged with bluish gray, a velvet-hlack spot between the antenna and each eye, antennæ brownish, the arista marked before the middle with a white ring, palpi rellow. proboscis brown; body brown, opaque, bluish.gray pruinose, mesonotum with four, the plenræ with one brownish pruinose vittr; steruoplenra hearing numerous short bristly hairs and with two stont bristles; legs yellow, opaque grayish pruinose, except a polished spot at base of the posterior side of the first two pairs and a streak on the posterior side of the hind ones; wings whitish, marked witb large pale gray spots and with a black cloud covering the small and hind cross-veins, a small black spot beneath apex of anxiliary vein, one slightly before middle of antepenultimate section of the fouth vein, and several smaller spots on some of the other veins; the gras color fills the whole marginal cell heyond apex of auxiliary vein, nearly the entire second half of the subnarginal, ete.; length $7 \mathrm{~mm}$. A female specimen captured by the writer.

"Habitat.-Los Angeles County, Cal.

"Type._Cat. No. 5500, U. S. N. M." Original description.

This species is not represented in the material examined. From its resemblance to maculutu, it is probably a sand dune form, although nothing has been reported about its habits.

A nopostomia maculata Darlington, n. sp. (Pl. IV, figs. 4 and 5).

Length $4.5 \mathrm{~mm}$; ; of wing, the same.

General color gray, wings spotted, cheeks cream colored.

Occiput, vertex and front gray; lower part of the front somewhat sellowish and pubescent; the two pairs of vertical and three pairs of fronto-orbital bristles arise from brown spots; a rather broad brown stripe extends from the ocellar bristles to the base of the occiput; antemuæ brown, third joint oval, arista white for about one-third its length at the proximal end; cheeks abont one and a half times the width of the eye; eyes transversely ovate; a black spot connects the base of the antenua with the anterior somewhat angular margin of the eye; vibrisse rather small.

Thorax gras; dorsum ish-gray; the dorsocentral bristies arise from large, distinet brown spots and the small hairs arise from small brown dots; the humeri, the lateral edges of the thorax, and the pleure, have a reddish-gray tinge; scuteiln m gras, bare except the ordinary four bristles, which arise from large brown spots, the apical pair confluent; the mesoplema has one large and one small bristle on the posterior edge, otberwise bare; the sternopleura with one strong bristle on the upper edge and with rather long, somewhat scattering pubescence below.

Abdomen gray, the small hairs arising from brown dots; h5poprgium of the male gray, globose, and sparsely covered with very short pubescence.

Wings whitish, with large brown blotches; there is a blackish spot on the auxiliary vein at its tip, one on the small cross-vein, and a small one on the anterior end of the hind cross-vein, forming a straight row; the pusterior end of the hind cross-vein also a little infuseated.

Legs pale yellow, except the femora, which are gray. 
Twenty-one males and eleven females. Aldrich: Pacific Grove, Cal., May 9 th.

This species is common on the sand dunes soutl of Point Pinos Light, on Monterey peninsula. It flies close down to the sand, resembling in its movements the drifting sand grains; when, it alights, its mottled color blends perfectly with the sand. No infor. mation was gathered as to its food habits or its larval stages.

A nondostoma mareginata Loew.

Length $5.4 \mathrm{~mm}$; of wing, $5.2 \mathrm{~mm}$.

Head yellow; occiput clay-5ellow, with a rather wide black stripe running "1, the middle to the vertex; front a little darker sellow, rather densels pubescent below; antenne small, testaceons, third joint roundish, arista noticeably enlarger at base; face strongly receding below; face and cheeks straw-yellow; one vibrissa on each sicle of medium size.

Thorax sellow, varsing to brownish, dorsum pubescent all over; the bristles arising from dots; scutellum sellow, bare except the ordinars bristles; mesopleura with one strong bristle and two smaller ones on the posterior edge, and a few small hairs on the lower anteriol corner; sternoplen w with one large and one smaller bristle on the upper edge, hesides pubescence and strong bristles below.

Abdomen varying from yellow to brown; hypopsgium of the male large. yellowish.

Wings sellowish; the cross-veins and the end of the auxiliary vein strongly infuscated, forming a straight line of three dots running diagonalls across the wing.

Legs entirely straw-yellow, pulvilli of about the same color.

Fourteen males and twelve females. Daecke: Lucaston, New Jersey, May 30th; Brown's Mills, New Jersey, June 21st; Manumuskin, New Jersey, May 10th. Melander: New Bedford, Massachusetts, Jume 12 th; Colorado. U. S. N. M. : Oswego, New York, July 1st (labeled Anorostoma carolinensis Desv.); Colorado. Cooley: East Flathead, Montana, July 25th. Johnson: Manumuskin, New Jersey, May 10th. Tucker: Tabernash, Coloralo, August.

LERI I Desvoidy.

This genus includes all the nembers of the fanily having four dorsocentrals, except those three small groups which offer additional generic characters distinctly their own (OEcother, with spines on the middle of the middle tibix; Eccoptomera, with very small eves, and Anorostoma, with peculiar face and oral margin); thus Leria is a residual genus, not homogeneous, yet difficult to divicle by satisfactory characters. The genus Scoliocentra, founded by

TRANS. AM. ENT, SOC. $\mathrm{XXXIV.}$

IA RCH. 1908. 
Loew to include forms with woolly hair and curved apical spurs on the middle tibix, we consider not sufficiently distinct, and allow it to lapse as a synonym, in part, of Leria. The characters apply mostly to the males, only with difficulty to the females, and there are intermediate forms. Loew himself states that Lcria iners has curved spurs, and in Centuries, iii, 51 he mentions his own Leria spectabilis as a Scoliocentra.

Among other generic characters, the eyes are generally round, the antenne short, with a round third joint, arista bare, either long or short; one humeral bristle; one propleural ; two suall prescutellar; scutellar bare, with the usual two pairs of bristles.

Leria specus Aldrich is a synonym of QEcothea fenestraiis, as we find from an explanation of cotypes.

Leria carolinensis Desv. is insufficiently described, and we fail to identify it, but give a translation of the original description.

Leria tibialis, genieulata and humeralis, all described originally by Zetterstedt in northern Europe, are reported from Greenland by Lundbeck and part by earlier entomologists. The species, however, seem to be badly confused, as in Katalog der Paläarktischen Dipteren, iv, 47, 48, Becker disposes of them as follows: tibialis he makes a synonym of serrata, humeralis of inscripta Meig. (European), while geniculata is in part a synonym of serrata, and in part of inscripta Meig., another European species. This tangle should evidently be unraveled by European entomologists; for the present it is hardly worth while for us to quote the descriptions, as they all read much alike.

The remaining Lerias of the 1905 Catalogue are included in the following table, with the addition of helvola and fraterna, formerly referred to Scolioccntra, and of glanca new species, and crassipes, describerl as European. Specimens of all the species tabulated have been examined by us except tristis and lutea; of these we translate the original descriptions.

\section{TABLE OF SPECIES.}

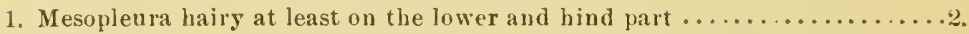
Mesopleura bare, at most with a few hairs close to the propleural bristle...4.

2. Mesoplenra entirely hairy in the nale, in the fenale the npper hind corner bare.............................. fraterna Loew.

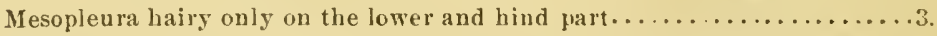

3. Abdomen black, hind margins of the segments reddish. pubescens Loew. Abdomen black, not banded .................. 
4. Two or more sternopleural bristles. . . . . . . . . .

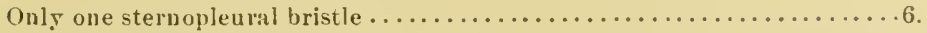

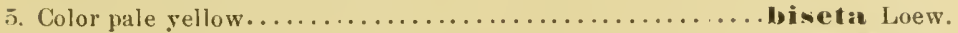

Color black or brown ........................

6. Pteropleura with one bristle and several bairs (halfway between the sternopleural bristle and the root of the wing) ....... pectinatis Loew.

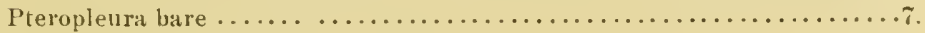

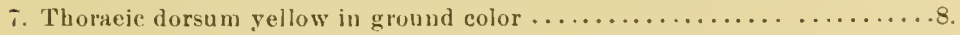

Thoracic dursum black in ground eolor, or mainly so..............

8. Large species $(10 \mathrm{~mm}$.), sellow, the abdominal segments sharply banded with black behind..............................

Small species $(4$ to $5 \mathrm{~mm}$.), abdomen not so marked $\ldots \ldots \ldots \ldots \ldots \ldots \ldots \ldots$.

9. Seutellum that . . . . . . . . . . . . . . . . . . . . . . Inteat Loew.

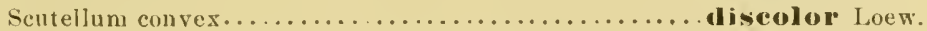

10. Abdomen wholly dark rellow, contristing with the thorax.

serrata Linn.

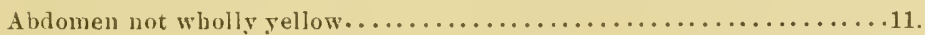

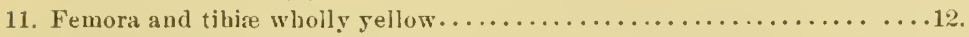

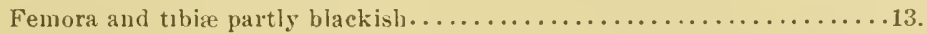

12. With olle vihrissa ...............................

With two vibrisse, the hiud metatarsus of the male shortened.

Iateus Aldrich.

13. Hind femora of the male with a comb of nine truncate black bristles below

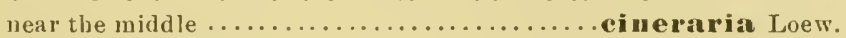

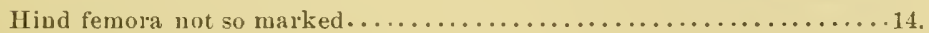

14. Humeri vellow. . . . . . . . . . . . . . . . . . . . . . . . . . .

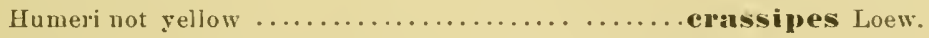

15. Arjsta short, not over twice as long as the body of the antemma.

leucostoma Loew. A rista considerably longer .........................

\section{Leria fraterua Loew.}

Scoliocentra fraterna Loew, Centuries, iii, 51.

Leria fraterna Coquillett, Wash. Acad. Sci., ij, $45 \%$.

Chocolate-brown, with a slight glaucous coating and a dense covering of fine black hajr on body and legs.

Head sellow, occinut and ocellar triangle brown, with a whitish pruinosity; front with numerons fine black hairs, extending down on the sides below the base of the antenna ; anterior fronto-orbital more than half as long as the posterior; cheeks fully half the height of the eyes, hajry on the lower half; palpi sellow; one vibrjssa; antenne reddish-brown, short, the arista of moderate length, thin, black.

Thorax chocolate-brown, with a whitish pruinosity, everywhere covered with suft, woolly black hair, except on the scutellum, metanotum, metastemum and prosterior half of the pteropleura; all the bristles except the scutellar are more slender than usual, the anterior three dorso-centrals and the humeral almost imperceptible; the position of the dorso-central row on each side is marked by a faint, interrupted brown line; scutellum bare, rellowish-brown; halteres sellow; one sternopleural bristle. 
Abdomen reddish-brown, with some irregular brown markings above, the last segment and hypopygium more yellow; very hairy, like the thorax; hypopygium snall, turned forward under the preeeding segment.

Legs brown, with the same woolly bair; preapical bristles of fore and hind tibire very slender; middle tibia with a stouter preapical bristle and a chnster of about five apical ones, of different sizes, the two or three largest distinctly curved; talsi gradually infuscated, with large, whitish pulvilli.

Wings with a faint brownish east, the veins vear the base, and the subcosta] cell yellọwish; costal setæ of medium size.

Length $8 \mathrm{~mm}$; of wing, the same.

Femule.-A little lighter in color, the hair every where shorter, and the bristles better developed, about as strong as in the average of the family.

Three females and two males. Aldrich: MIoscow, Idaho, and St. Anthony Park, Minnesota. Johnson: Montreal, Canada, June 20th. U. S. N. M. : Ungava Bay, Hudson Bay Territory, L. M. Turner, Nos. 280 and 4186 .

This is evidently a wide spread northern form; the type locality is Sitka, and it has been reported from W'hite Mountains, New Hampshire.

\section{Leria pubescens Loew.}

Length of boriy $7.3 \mathrm{~mm}$; of wing, $8.1 \mathrm{~mm}$.

Head, including the oeciput, sellow; front entirels sellow, rather densely pubescent; rertical bristles rather long and stout; antennse yellow, first two joints reddish-yellow; arista long and slender, only microscopieally pubeseent; vibrissæ one on each side, rather long and stout; eheeks straw-yellow, abont three-fifths the width of the eye.

Dorsum of the thorax cinereous; the lumeri and the lateral edges of the dorsimn somewhat reddish; a rather distinet median brown line runs almost the length of the thorax; the dorso-central bristles arise from brown spots, which are almost confluent; the dorsum rather densely pubescent; scutellum reddishFellow, bare except the ordinary four bristles; mesoplenra reddish-brown, uther sparsely pubescent; besides one strong bristle, the stermopleura has ratber dense and fairly long pubescence.

Abdomen brownish, densely covered with long, black pile; the posterior edge of each segment reddish-yellow; hrpopygium of the male of medium size, sellow.

Wings with a blownisb tinge; cross-veins very slightly infuscated; all the veins distinctly browu.

Legs reddish-sellow, densely pubescent all over; a rather long, hrown spot at the apical end of the front tibia; last three tarsal joints of the frout legs, the last two of the middle legs, and all those of the hind legs black.

One male, one female. Brues: Horseshoe Cave, Door County,

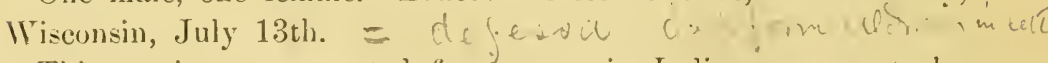

This species was reported from caves in Indiana; see note by Blatchley under Ecothea fenestralis. 


\section{Leria defiessa Osten Sacken.}

Length $5.5 \mathrm{~mm}$.; of wing $6.2 \mathrm{~mm}$.

IIead yellowish; occiput brownish pollinose; front pale yellow, wholly pubescent; foremost fronto-orbital bristle about half the size of the posterior one; antennæ reddish-hrown, third joint roundish, rather large; arista only microscopicalls pubescent; face receding; cheeks one-half the width of the ere: vibrissæ one on each side, rather strong.

Dorsum of tholax grayish-brown; the dorso-central bristles arise from large brown spots and the small hairs from smaller spots; a middle brown line runs almost the whole length of the thorax; humeri yellow; pleura rather dirty sellow; mesopleura rather sparsely pubescent; sternopleura, besides the one strong bristle, densely pubescent all over; scutellum bare except the ordinary fonr bristles, sellow.

Abdomen gray; balteres yellow; hypopygium of the male of medium size, rellow.

Wings with a brownish yellow tinge.

Legs yellow; front femora somewhat infuscated.

Four males and nine females. Melander: Indiana. U. S. N. M.: Cheat Mt. Cave, Files Creek, W'est Virginia; Boone's Cave, Hickman's Landing, Kentucky. Johnson: Niagara Falls, New York, June 28th.

This species was first described from a cave in Kentucky, and has been reported from other eaves in Kentucky and Indiana. See note by Blatchley under Ecothea fenestrulis.

\section{Leria biseta Loew.}

Length $5.7 \mathrm{~mm}$.; of wing, $6.4 \mathrm{~mm}$.

Yellow, abdomeu somewhat infuscated; in general appearance resembles the genus Helomyza.

Head yellow, front lemon-yellow, lower part pubescent; antenuæ reddishyellow, third joint round, arista rather long, only microscopically pubescent; cheeks straw jellow, about three-fourths the width of the eres, which are round, occiput entirely sellow, a tuft of small black bairs parted in the middle at the base of the occiput.

Thorax yellow, the dorso-pleural suture reddish, dorsum rather densely pubescent ; scutellum lemou-sellow, bare except the ordinary four bristles; mesopleura bare except a few very small hairs on the anterior edge; sternopleura with two strong bristles of nearly equal size on the npper edge, also with sparse pubescence.

Abdomen blackish-yellow; the second, third and fon rth segments with a black posterior margin; hypopygiuns of the male bright yellow, rather large and densely pubescent.

Wings large, with a hrownish-rellow tinge; the hind cross-vein and the apices of the longitudinal veins distinctly bordered with brown; spines of the costa sellow.

Legs yellow, densely covered with black hairs; distal end of the hind femnr black; the last four tarsal joints of the front legs black; pulvilli white, rather consjicuous.

TRANS. AM. ENT. SOC. $X X X I V$.

II A RCH, 1908. 
One male specimen. Johnson: St. Johnsbury, Vt., Jnne 26 th.

This species was described from European material; it has since been reported from Sitka, and White Mountains, New Hampshire.

\section{Leria iners Meigen.}

Length of body $7 \mathrm{~mm}$; of wing $7 \mathrm{~mm}$.

General color blaek; legs yellow, infuscated; hypopygium sellow; wings brown veined.

Front brown, pubescent; the oceiput and a narrow area running forward, including the vertical triangle, blark; eheeks sellowish-brown, ahout threefourths the width of the eye; antenna brown, third joint oval, the arista missing in the deseriber specimen; vibrissæ one on each side, long.

Dorsum of the thorax grayish-black, covered with a yellowish pollen, densels pubescent all over, the small hairs arising from small black dots; scotellum same color as the thorax, entirely bare; pleura grayisloblack; spiracle on the proplenral suture conspienous; a bunch of small black hairs on the mesopleura just above the front coxa, mesopleurl otherwise bare.

Abdomen black, rather densely covered witb long black hairs; hspopygium rellow.

Wings slightl̦ brownish; wing reins distinctly brown; spines of the costa exceptionally long and sharp.

The outside of all the femora black except the ends, which are yellow; all the tibize and tarsi yellow; front tarsi flattened and widened from abont the end of the second joint; spurs of the middle tibiæ curved.

One male. Aldrich: Moscow, Idaho.

A European species hitherto reported from North America but once, without locality.

\section{Leria pectinata Loew.}

Length of body $4.7 \mathrm{~mm}$.; of wing $4.4 \mathrm{~mm}$.

Head yellow; front somewhat safrron-rellow, pubescent; orbits of the eyes whitish; the oceiput, a portion of the vertex surrounding the fronto-orbital bristies and the rertical triangle hlaek; antennæ reddish-yellow, third joint brownish or brownish-black; arista long and slender, bare; cheeks about three-fourths the width of the eyes, somewhat clay--yellow; vibrissæ ratber strong.

Dorsum of the thorax cinereous, rather denseif eovered with black pubescence: pleuræe entirely gray; propleura with three or four hairs besides the one strong bristle over the fore coxa; mesopleura entirely bare: pteropleura with a distinct bristle and several bairs (this seems to be one of the best marks of distinction); sternopleura covered with dense pubescence, and with one bristle; scutellum hare, yellowish.

Abdomen cinereons, the posterior margins of the segments usually sellowish, sometimes entirely cinereous; bypopygium of the male also jellowish.

Wings somewhat brownish, veins entirely brown.

Legs testaceous; front femora somewhat infuscated; tarsi brownish; the front metatarsus in the male with an enlarged lower apical nargin, quite distinct when seen from the proper angle. 
Seventeen females and four males. Aldrich: Brookings, South Dakota, June 11th; Moscow, Idaho. Melander: Austin, Texas, November 16-19th. U. S. N. M.: Mesilla Park, New Mexico, February 18th. C. F. Baker: Pine Lake, California.

The species was originally described from Texas; it has been reported from "upper burrows of desert rodents" in Arizona. Professor Melander informs me that he collected it at Austin, Texas, in a novel manner: he buried wide mouther bottles up to the neck in ant hills, left them over night, and on approaching next morning slipped a cork in before the flies had time to be disturbed.

\section{Leria helvola Loew.}

Scoliocentra helvola Loew, Centuries, ii, 80.

Male.-Yellow, the largest of the fanily, with large yellow wings.

Head yellow, the lower laalf deeper yellow, sharply linited above; face receding, oral margin not very distinct, one strong vibrissa; cheeks one-third the height of the eye; antenna short, yellow, with long, thin arista.

Thorax yellow, bristles fairly well developed, dorsum with rather dense black hair; pleure bare except the sternopleura, which is covered with fine, black hair and his one bristle; sentellum bare, lighter sellow than the rest of the dorsum, with the usual bristles; balteres yellow.

A bdomen yellow, with dense black hair, bind margins of the segments narrowly blackish (less distinet than in the female); hypopyginm small and inflected; halteres yellow.

Legs yellow, including all the tarsi; preapieal bristles slender on front and hind tibiæ; middle tibiæ with stonter ones, and a eluster of several apieal ones, the larger ones distinetly eurved; front tibiæ with a row of bristles above and one below; hind tibie with a short row above near the apex: pulvilli rather large, whitish.

Wings large, rellow, the posterior eross-vein and the tips of the three veins in the apex margined with brown; a distinetly yellower tinge accompanies all the veins. last seetion of fifth vein only one-third as long as the posterior crossvein; eostal setæ strong.

Length $8.5 \mathrm{~mm}$; of wing $9.5 \mathrm{~mm}$.

Femule.-Paler yellow, less hairy, bristles larger, distinet narrow black bolders behind on the second, third, fourth and fifth aboiominal segments.

One male, five females. Aldrich: a pair from Ithaca, New York, June 5 and July 6,1897 , which were originally in the collection of Cormell University. Daecke: Orange Mountains., New Jelsey, August, a female collected by Weidt. U. S. N. M.: White Mountains, New Hampshire. Johnson : North Mountain., Pennsylvania, August 28, 1897, and Elkhard, Indiana.

Originally described from Illinois, but the distribution is rather eastern. 


\section{Leria discolor Loew.}

Length of body $5.4 \mathrm{~mm}$.; of wing $4.6 \mathrm{~mm}$.

General color yellow; abdomen somewhat darker.

Head yellow; front saffron-yellow, wholly pubescent; antennæ same color, third joint round; arista noticeably enlarged at base, the base sellow, remainder black, only microscopically pubescent; cheeks about one-balf the width of the round eyes, straw yellow; vibrissæ one on each side, rather large and strong; orbits of the eyes somewhat silvery pollinose.

Thorax yellow ; dorsum densely pubescent with black hairs; scutellun bright sellow, bare except the ordinary four bristles; mesopleura yellow, bare except three or four small hairs at the lower anterior corner; sternoplenrad with one strong bristle and about five small hairs on the npper edge, also numerous hairs ou the lower part.

Abdomen yellowish-brown; hypopygium of the male rellow, of medium size.

Wings unspotted, almost byaline; wing veins yellow; spines of the costa rather small.

Legs yellow; tarsi somewhat darker; pulvilli dirty white, rather conspicuous.

One male and three females, from the type locality. U.S. N. M. : Mt. Washington and White Mountains, New Hampshire.

\section{Lerian serrala Linn.}

Length $5.3 \mathrm{~mm}$.; of wing $5.9 \mathrm{~mm}$.

Head yellow, occiput black; front saffron-yellow above, lighter below, densely pubescent ; first two joints of the antennæ yellowish-brown; third joint black, arista long, only microscopically pubescent; cheeks yellow, three-fonrths the width of the ese; more than one vihrissæ on each side.

Tborax ash-gras, densely pubescent; a narrow brown stripe runs down the middle, with a wider one on each side, from which the dorso-central bristles arise; scutellum ash-gray, bare except the ordinary four bristles; mesopleuræ bare except a few small hairs at the lower anterior corner; stemopleura, besides the one strong bristle, with rather dense pubescence.

Abdomen wholly reddish-yellow or saffron-yellow, bypopygium of the male of the same color, small.

Wings gravish translucent, veins yellowish-brown.

Legs yellow; front femora infuscated on the outside; last three or fou $r$ tarsal joints of all the legs blackish.

Nine males and nine females. Cooley : Bozeman, Montana, May 27th to July 7th. Melander: Mayfield Cave, Bloomington, Indiana. Brues: Horseshoe Cave, Door County, Wisconsin, July 13th. Aldrich: Moscow, Idaho.

The preceding species is very similar in appearance to Tephrochlamys rufiventris; it can be distinguished by laving four dorsocentral bristles, shorter antenna and more bristly epistoma.

The earliest described species of the family; common in many parts of Europe as well as North America; frequently collected in caves, also on windows of houses. According to Bratuer, the larve have been bred from fungi and from hen manure. 
Leria Iatens Aldrich.

Brownish-black, the head, kuees, venter and tip of abdomen reddisb; two vibrissæ on each side.

Length $4.8 \mathrm{~mm}$.; of wing $5 \mathrm{~mm}$.

Front saffrou-yellow; occiput, a narrow stripe including the fronto-orbital bristles, and a broader area including the vertical triangle, black; first two antennal joints red dish-yellow, third joint black, arista long, only microscopically pubescent; cheeks sellow, ahont three-fourths the width of the ese; two strong vibrissæ on each side, the frout one somewhat the longer.

Thoras black, dorsum rather densels pubescent; seutellum hlack, bare except the ordinary four bristles, which are rather unusually long; mesopleura black. bare; sternopleura with a row of four or five unequal bristles on the upper edge, pubescent below.

Abdomen black; the venter and the posterior horder of each segment and all the fifth segment reddish-yellow in the female; hypopsginm of the male sellow, of medium size.

WVings grayish, almost byaline, unspotted; veius brown; spines of the costa rather small and imconspicuous.

Coxæ and femora black, hairy, the latter stout; trochanters and knees red; tibire usually with considerable red or reddish-sellow color, especially near the middle; tarsi almost uniformly brown.

Three males and three females. Aìdrich (cotypes): Porter's Cave, Indiana, July 14th. Milwaukee Public Museum: Horseshoe Cave, Door County, Wisconsin, July 13th. Melander: Austin, Texas, January 20th.

See note by Blatchley under Ucothea fenestralis.

\section{Leria ciuerarial Loew.}

Length of body $6.2 \mathrm{~mm}$. ; of wing $7.7 \mathrm{~mm}$.

Ash-gray; a comb of about nine strong, blunt bristles on the hind femora of the male.

Head yellowish; veciput gray, the gray portion extending forward on the edges so as to include the fronto-orbital bristles, and in the middle so as to include the vertical triangle; front from saffron-sellow above to lemon-sellow below, rather densely pubescent; eses round, abont twice the width of the cheeks; antennæe brown, first two joints sellowish-brown; arista long, nearly hare; vibrissa long and rather stout.

Thorax ash-gray; dorsum pubescent, the small hairs arising from distinct brown dots, the bristles arising from larger brown spots; upper surface of the scutellum gray, but yellowish on the margins, bare except the ordinary four bristles; mesoplenre bare except three or four hairs on the lower anterior corller, just above the front coxa; sternopleuræ with oue strong bristle and four or five smaller hairs on the upper edge, besides numerous bairs on the lower part.

Abdomen gras, bspopygium of the male sellow, medium sized; in the female the last two segments are reddish-sellow and the rentral side of the abdomen is red dish-browu.

TRANS. AM. ENT. SOC, XXXIV. 
Wings hyaline except the subcostal cell.

Legs pale sellow, tarsi brownish; bind femora of male with a comb of about nine strong, blunt, black bristles on the inner or hind side.

'Two males and three females. Aldrich: Moscow, Idaho, June 7 th.

Note.-Our specimens agree with Loew's description in every particular, except that he says that the dorsum of the thorax is unspotted, while in all of these it is distinctly spotted.

\section{Leria crassipes Loew.}

Loew, Zeitsch. f. Ent. xiii, 68 (Blepharopteru).-Germany.

Male-CRather small, dark grayish, the large hypopygium and the legs testaceons, the coxa and the chest between them with very dense pile. Length 5$5.2 \mathrm{~mm}$.; of wing $5.2-5.3 \mathrm{~mm}$.

Blackish-gray. Front somewhat narrower than in most of the other species. Occiput and vertex blackish-gray. The anterior of the two fronto-orbital bristhes rather strong. Antenuæ reddish-yellow or yellow, the third joint sometimes brown on a great part of its outer side; arista lather short, with pubescence somewhat more noticeable than in other species. Eyes large, ronnded; cheeks of only moderate breadth; vibrissæ one on each side, long. Thorax with quite dense and rough hair; an extremely small dot at the base of each hair; between the dorso-central rows of bristles are two faint brownish-black lines, generally much abbreviated in front; on each sire are two spots of the same color, still fainter, one before and one behind the suture, the latter one larger. Scutellnm concolorous with thorax. Pleure more pure einereous than the dorsum, sometimes somewhat brownish ; only one sternoplenral bristle, but the row of hairs in front of it are somewhat strong and bristle-like, so that one or two of them may approach the size of bristles; mesopleura bare; between the middle and hind coxie with dense and stout bristles. Abdomen blackish cinereous, the hind nuargius of the segments often brownish-red or almost testaceous. Hypopygium brown-yellowish or more red-yellowish, large and thick, with sparse bair. Legs hrownish-yellow, densely hairy; tarsi infnscated; femora very stroug, the front ones with many bristies; on the underside of all the femora are only the usual hairs, bnt very dense, Wings with a perceptible tiuge, more gray-brown than yellow-brown; subcostal cell narrow; bristles of the costa numerous.

The preceding is a translation of the entire original description. We have two female specimens, sent us under this name from the United States National Museum, from Ungava Bay, Hudson's Bay Territory, Nos. 4116 and 4186, collector L. M. Turner. The description applies very well, only as these are females the pilosity is not so strong as described, especially on and between the coxr; the row of hairs on the sternopleura, while rather large, do not approach the stature of bristles. The specimens having been in alcohol, it is impossible to say much about the lines and dots of the thorax. The species was described from Europe, and this is the first published reference to its occurrence in North America. 


\section{Loria leucostoma Loew.}

Length of bod $5.7 \mathrm{~mm}$; of wing $4.4 \mathrm{~mm}$.

Vertex and occiput gray; front saffron-sellow; auteuna brownish yellow, third joint round, arista black, only microseopically pubescent; orbits of the eyes whitish; face somewlat cream colored, clieeks about one-third the width of the ese; eyes round ; vibrissæ one on each sirle, rather strong.

Dorsum of the thorax ashy gray, rather densely pubescent; dorso-central bristles rather slender; humeri conspicuously reddish-rellow; propleuræe reddishsellow; mesopleuræ gray except the margins, which are rellow, bare; sterunpleure yellowish, one strong bristle and four or five hairs on the upper edge; scutellum sellow, bare except the ordinars four bristles.

Aldomen from vellow to brown, each segment with a silvery posterior margin ; hrpopygium rellow, of medium size.

Wings entirely liyaline; spines of the costa small.

Legs sellow; all the tarsi and the distal end of the tibixe brown.

Three male specimens. Johnson: Hampton, New Hampshire, May 25th and September 12th. Aldrich: Mt. Constitution, Wash. ington, July 7th. U. S. N. M. : White Mountains, Morrison.

\section{Leria glauca Ald rich, u. sp.}

Length $6.1 \mathrm{~mm}$.; of wing $7.5 \mathrm{~mm}$.

Occiput, vertical triangle and thorax, except apical part of scutellum, of it smooth glaucous gray color, much as in Tephrochlumys rufiventris and Leria serrata. Remainder of head reddish-cellow, third joint of anterisa infuscated, the arista long and slender. Cheek fully half the width of the eye. A single vibrissa, the bairs behind it small.

Bristles of the thoracic dorsum long, the iutervening bairs fine and short; the bristles are seated on blackish dots; a slender median brown line on the dorsum, abhreviated at both ends; scutellum yellowish on the apical part, flat and bare, with the usual four bristles; pleura concolorous witl dorsun, mesopleura and pteropleura bare, except a few hairs on the former in its lower frout corner: stermopleura with one bristle and corered with fine bairs, whicb become larger below. Halteres rellow.

Abdomen dark jellow in ground color, but considerably blackened above except near the apex; hind margins of the segments ligbter except the first.

Legs including coxe yellow, the tarsi darker toward the tip; claws and pulvilli large; hind metatarsus with two bristles below near the base.

Wings byaline, long and wide.

A single female, Pullman, Washington, April 16, 1904, from Professor Melander.

The species has a marked resemblance to serrata, but the abdomen is considerably black above, the hairs in the vicinity of the vibrissa are small; the anterior fronto-orbital bristle is very small, while in serrata it is nearly as large as the one behind. 
Leria Iutea Loew.

"Male and female. Wholly ochraceous, opaque, tarsi brownish toward the apex, arista only slightly pubescent, one strong vihrissa on each side, mesopleura bare, scutellum bare except the usual bristles; all the femora stout; hypopyginm of the male small; wings a little cinereons, spines of the costa minute.

"Related to Leria inscripta and crassipes. Entirely ochraceons, opraque. Antenne concolorous, first two joints very short, third rather large, round, with a slender, almost bare blackish arista. Eyes roundish. Cheeks rather broad. One stout vibrissa on each side. Mesoplenra bare; one stemoplenral bristle. Segments of the abdomen subequal, the middle ones sometimes brown or black, except the hind edges. Hypopsgium of the male small, concolorous. Coxa and mesosternum witl black pile. Legs ochraceons, the femora stout, tarsi brownish toward the apex. Wings yellowish subhyaline, brown toward the apex and hind border, spines of the costa small. (Sitka; Sahlberg)." Entire description translated.

This species we are unable to recognize in our material; the reference to inscripta raises the suspicion that the geniculata from Greenland may be this species, and this may really be identical with inscripta. On this we have no evidence.

Mr. Fyles has reported lutea from Quebec.

Leria trist is Loew, Centries, ii, 84.

Female.-Small, blackish-gray, head yellow, antenuæ brownish-black, seta short, nearly bare; legs black; wings grayish byaline, spines of the costa sparse and small. Length $3 \frac{1}{3} \mathrm{~mm}$; of wing $3 \frac{1}{2} \mathrm{~m}$.

Blackish-gray. Head yellow, occipnt and vertex blackish-gray. Antenna brownish-black, first two joints brown, third round, arista short, nearly bare. Eyes rather large, round; cheeks rather snall; face receding below, vibris:at rather small. Pleuræ and scutellum bare except the ordinary bristles. Legs eutirely black. Halteres pale rellowish. Wings ashy hyaline, the stigma very pale brownish; veins blackisb, spines of the costa scattered and small. (Wimnpeg; Kennicott.) Translation of entire description.

This species is not among those we have examined. It has, however, been seen from the Commander Islands, Alaska, by Coquillett, and is also reported from New Jersey by Johnson in Smith's Catalogue of the Insects of New Jersey.

Scatophaga camolinensis Desvoidy, Myodaires, 629.

(Referred to Leria in Ann. Soc. Ent. France, 1841, 258.)

"Nigro-subcinerea; facie alba; fromtalibus rubris; pedibus fulvis, alæ subflavescentes."

Length $8 \mathrm{~mm}$. This species, lacking the antenna, may belong to a different section, but it shows most of the characters of a Scatophuga.

"All the body brownish-black, with a very light einereons covering; face white; frontalia fulvons, broad anteriorly; legs yellow, with a little dark brown on the fenora; wings with a light rellowish tinge, markings little devcloped. 
"This species, coming from Carolina, was given me by M. Bosc under the name Musca flavescens."

Entire description-translated into English except the diagnosis. IVe are unable to identify the species with certainty or plausibility from the vague characterization. Perhaps it was really a Scatophagu, as the redness of the front would indicate.

A pair of specimens from the U. S. N. M., locality Oswego, New York, came to us under this name, while others, not specifically distinct, from Colorado were labeled Anorostoma marginata, we think correctly.

\section{H ELOM YZA Fallen.}

Humeral bristle absent; propleural absent; five dorso-centrals; three supra-alar; two notopleural; one presutural; scutellar two pairs; one fronto-orbital; one sternopleural. Face with distinctly projecting oral margin; anteunx with somewhat elongated third antennal joint, the arista in most cases more or less plumose. Wings large, in the majority of cases with markings, which usually border the cross-veins and the apices of the longitudinal veins.

In this genus the transverse suture of the thorax runs obliquely forward from its origin at the side, so that the portion behind it is larger than usual; four of the five sternopleural bristles are behind the suture.

The species are as a rule rather large, yellow, somewhat elongate forms, easily distinguished by the absence of humeral and propleural bristles, together with the large number of five dorso centrals.

We have seen all the species of the table except the Mexican forms and apicalis; the descriptions of these, together with those of 'Walker's two supposed species, are reproduced at the end of the genus.

TABLE OF SPECIES.

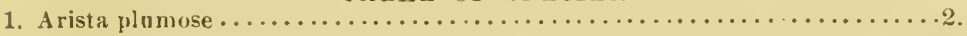

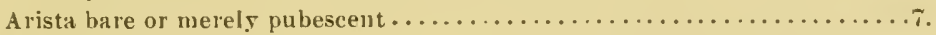

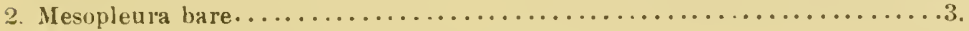

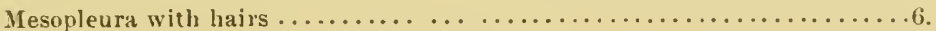

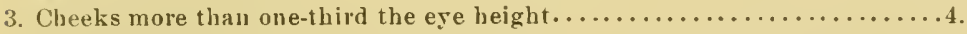

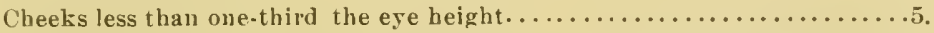

4. Scutellum pilose .............................

Scutellum with only a very few scattering hairs.........plumata Loew.

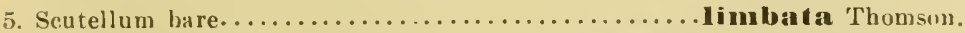

Scutellum pilose...................... quinquepunciata Say.

6. Ocellar knob black, face with narrow silvel-white lateral margins (Mexico).

Ocellar knob uot black, and no silver-white margius of face.

punctulata Vau der IVulp.

nemorum Meigen. 
7. Blackish spots of different sizes in all the cells of the wing (Mexico).

polystigua Vam der Wulp.

A ronnded dot botween the second and third veins (Mexieo).

distigun: Van der Wulp.

A black spot on each side of the ocellar spot (Mexico).....inicns Giglio.Tos.

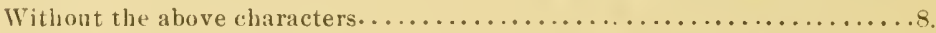

8 . Wiugs entirely lyaline ......................

The transverse veius and apices of longitudinals distinetly infuseated.....9.

9. Scutellum except the sides bare ................... ap icalis Loew.

Scutellum pilose.$\ldots \ldots \ldots \ldots \ldots \ldots \ldots \ldots \ldots \ldots \ldots \ldots \ldots$ barberi $n$. sp.

Il elomyza longipennis Loew:

Length $8.1 \mathrm{~mm}$; of wing, the same.

Large, rather pale yellow to reddish-yellow specics, marked with a blackish triangle on each of abdominal segments two to five; this triangle as wide as the segment and oceupying all its posterior part, the apex of the triangle pointing cephalad and indistinctly approaching the next preceding segment.

Head bright sellow, front wide, with one fronto-orhital on eacb side; antemne short, the third joint a little elongated ; arista with short but dense plumosity; face and cheeks pale yellow; vibrissæ small; cheeks hardly half as high as the eye.

Dorsum of thorax testaceous, not lutted; scutellum flat, pilose above; mesoplen ra bare; stemopleura with one strong bristie, and a few delicate sellow hairs, the lower part with longer mostly yellow hairs.

Abdomen lighter sellow, marked with black as indicated above; hrpopygium small, yellow; venter in the male with long yellow hair.

Legs rellow, femora in the male stout, all with a row of spines on the outer side, and abundant, long yellow hair on the lower part; last two joints of the - tarsus blitek.

Wings yellowish, large and broad, the cross-veins and tips of longitudinals with only a trace of infuscation, strongest on the hind eross-vein.

Three males and one fenale. Johnson: St. Johnsbury, Vermont, June 27th; Delaware Water Gap, New Jersey, July 11th; North Momntain, Pennsylvania, August 2Sth. Daecke: Bloomfield, New . Tersey, September (IV eidt).

The type locality was New York, and the species had been reported from New Jersey by Johmson in Snith's Catalogue.

\section{IIelomyza plumala Loew.}

Length 4.6-5.2 $\mathrm{mm}$.; of wing $5.9 \mathrm{~mm}$.

General color pale yellow; legs somewhat lighter colored ; five brown spots on the wing.

Head yellow; eyes medinm sized, roundish; front saffron-yellow, lower part densels pubeseent; antennæ same color or slightly darker, third joint oval; arista rather long, plumose; eheeks about half as wide as the ejes, paler than the front; vibrissæ rather small.

Dorsum of thorax saffron-pellow; besides the ordinary bristles it is densely pubescent all over, the small hairs arising from small browu dots; humeri lighter in color; mesopleura pale sellow, entirels bare; sternoplenra pale yellow, with several small hairs besides the one strong bristle; scutellnm thinly hairy and with the nsual four bristles. 
Wings slightly sellowislı; small and large cross-veins and the apices of the longitudinal veins distinctls bordered witl hrown.

Abdomen rellow, each segment with a blackish posterior horder; hypopygium of male large, brighter yellow.

Legs light yellow.

Eight male and seven female specimens. Aldrich: Knoxville, Tennessee (Summers); Battle Creek, Michigan; South Dakota, July 2nd. U. S. X. MI. Oswego, New York; Milwaukee County, Wisconsin, July 15th. Johnson: Philadelphia, Penna.; Delaware Water Gap, New Jersey; Montreal Island, Quebec; Auburndale, Mass.; Burlington, Vermont, and Ft. Collins, Colorado; dates from June 25th to August 14th. Melander: Wisconsin (Wheeler); Angora, Penna., September $17 \mathrm{th}$.

The type locality was New York.

Helomyza linbatat Thomson ( $\mathrm{Pl}$. IV; fig. 6).

Leugth $5.3 \mathrm{~mm}$, ; of wing $6.2 \mathrm{~mm}$.

General color pale yellow; legs a little lighter; wings strongly infuscated.

Head sellow; eye large, round; vertex and upper part of the front saffronsellow, lower part of the front lighter sellow, densely pubescent; ocellar triangle also pubescent; antenuæ pale pellow, third jomt oval; arista of moderate lellgth, plumose; vibrisse of medium size, one on each side; cheeks narrow.

Thorax entirels pale sellow, dorsum densely pubescent; mesopleura bare; sternopleura with one strong bristle and numerous small black bairs; scutellum saffron-pellow, bare except the ordinary four bristles and an occisional small hair near the margin.

Wings with the marginal and usually the first submarginal cell distinctis infuscated, also the ends of all the longitudinal veins; both cross-veins distinctly bordered with brown.

Abdomen of the female nearly black, that of the male not nearly so dark, but with a black band on the posterior edge of each segment; hypopygium of the male large, yellow.

Legs straw-sellow; hind knees blackish.

Five male and nine female specimens. Aldrich: San Maten, Pajo Alto and San José, California, January 26th to April 12th; Orcas Island, Guemes Island, and Keyport, Washington, July 7 th to August 7 th.

Type locality, California.

\section{Helomyza quinquepunclata Say.}

Helomyza latericia Loew, Centuries, ii, 89.

Length 5.7-6 nm.; of wing $6 \mathrm{~mm}$.

General color yellow, the large and small cross-veins and the apices of the longitudinal veins distinctly bordered with brown; scutellum entirely pilose; eyes large. ovate.

Front saffron-5ellow, broader at the vertex than at the antenna ; face lighter jellow, broadening from the antenna down; antennæ sellow, third joint large,

TRANS. AM. ENT. SOC. $\mathrm{XXXIV}$.

M A RCH, 190 S. 
obloug-ovate, with plumose arista; cheeks narrow, pale yellow; vibrissæ one on each side, of medium size. At the base of the orciput is a tuft of hlack hair parted in the middle.

Dorsum of thorax with numerous smalt brown spots, ont of which arise the small hairs; ground color saffron-yellow; mesoplenra (utircly bare, somu what paler yellow; sternopleura with one strong bristle and numerous small hairs below; seutelium the same color as the thorax, wholly piluse.

Wings slightly brownish, the front and hind crosi-veins and the apices of the longitudinal veins distinctly bordered with brown.

$\Lambda$ bdomen yellow, the hind margin of each segnent black; hypopginm of the male rather small.

Legs straw-yellow, the last three tarsal joints of all the legs black ; proapical bristles of the tibix long and slender.

Four female and one male specimens. Aldrich: Battle Creek, Michigan. U. S. N. M. : Southern Georgia. Johnson : Opelousas, Louisiana, March to May (Hough).

Type locality, Connecticut; it has also been reported from the White Mountains of New Hampshire by Mrs. Slosson.

This species was redescribed by Loew as $H$. latericia, but in a mote appenderl to the description he says he should have identified it with quinquepunctata had not Say asserted the antenna of the latter to be five spotted. This was a mistake on the part of Loew, since Say said nothing of the kind, but located the spots on the wing.

(In my Catalngue I made Loew's plumata, instead of latericia, a synomym of quinquepunctata; this I am now satisfied was due to some confusion of names, as latericia is clearly the syuonym.J. MI. A.)

Helomyan nemorum Meigen, Srst. Beschr., vi, "52.-Europe. Loew, Zeitsch. f. Ent. Bresl., xiii, 22. Schiner, Fauna Austr., ii, 28. Czerny, Wien. Ent. Ent. Zeit., xxiii, 223.-Europe and North America.

Helomyza assimilis Loew, Centuries, ii, 87.-Hudson's Bạ Territory.

Length $5.9 \mathrm{~mm}$.; of wing $6.4 \mathrm{~mm}$.

General color yellow ; small and large cruss-veins, and the apices of the longitudinal veins distinctly bordered with brown; mesopleura pubescent.

Head yellow; front saffron-sellow, lower part pubescent; anteme saffronyellow, third joint rather large, oval; arista long, plumose; eyes roundish, about two and a half times the width of the cheeks; cheeks straw-yellow.

Dorsum of the thorax densels pubescent, the small hairs arising from small brown dots; ground color saffron-yeliow; mesopleura with numerous small hack bairs; sternoplęura besides one strong bristle with numerons small black hairs; pleura sellow; scutellum saffron-rellow, wholls pilose.

Wings slightly brownish; the costal and subcostal cells strongly infuscated; the cross-veins and the apices of the longitulinal veins distinctly bordered with brown; spines of the costa rather long. 
Abdomen sellowish, but more or less infuscated; hypopsgium sellow, rather large.

Leys straw-yellow; fore femora stout; last three joints of all the tarsi black.

Four male and three female specinens. C. F. Baker: Ormsly County, Nevada. July 6th. Aldriclı: San Juan Istand, Washingtom, May 31st ; Juliaetta, Idaho, July 9th; Moseow, Idaho; Craig's Mtt., Jalaho; Colorado (E. S. Tucker).

Inew did not identify nemorum from North America, but named our species assimilis, stating that it did not differ from nemorum, exeept in haring a little shorter plumosity of the arista and general paler color; Czerny identified his American material as nemorum, and did not identify assimilis, merely quoting the description (op. cit., p. 222). From these facts I feel safe in making assimilis a synonym of nemorum.

\section{HeJomyzat zetterstedti Loew.}

Length of body $5.6 \mathrm{~mm}$.; of wing $6.9 \mathrm{~mm}$.

General color rellow; wings hyaline.

Front leather-yellow, lower part pubescent; eres medium size, round; cheeks straw-yellow, abont two-fifth the width of the ere; antennæ rellow, lhird joint rather large, somewhat infuscated, oval; arista rather long, not plumose, but merels pubescent; vibrissæ of medinn size; at the base of the occiput is a bunch of small black bairs.

Thorax yellow; dorsum clay-yeliow, rather sparsely pubescent; the small hairs not arising from dots; mesopleure clay-yellow, bare; hesides one strong bristle a few scattering small hairs on the sternopleura; scutellum yellow, bare.

Wings entirely hyaline.

Abdomen blackish sellow, hypoprginm of the male bright yellow, rather large.

Lcgs yellow, femora lemon-yeliow, tibire and all but the last two joints of the tarsi straw-yellow, last two tarsal joints black, inner side of hind and middle fenora glabrous, at the apex of the femur is a black spot on the inner side.

Fifteen female and eight male specimens. Aldrich: Mt. Constitution, Washington, July 7 th ; Friday Harbor, Washington, May 29th. U. S. N. M. : Popoff Island, Alaska, July 8th.

\section{Helomyza barberi i. sp.}

Length $5.8 \mathrm{~mm}$.; of wing $6.3-7 \mathrm{~mm}$.

General color brown, wings brownish, a brown ring or spot at each end of the hind tibia and at the distal end of the front tibia.

Head rellowish; front ochre-yellow except a brownisb strip running down from the vertex on each side including the fronto-orbial bristles, and a wider lrown area in the middle including the ocellar triangle; all the yellow portion of the frout pubescent, a strip of small black hairs extending from the ocellar bristles to the vertical bristles; antennæ yellowish-brown, third joint oval, arista long and slender, only microscopically pubescent.

Dorsum of the thorax yellowish-brown, wholly pubescent, the small hairs arising from small brown dots, the bristles arising from larger brown spots; in 
the darker specimens a central browu stripe runs the full length of the thorax; scutellum pubescent, except a bare strip in the middle; pleuı clar-yellow; mesopleura with numerons strong bairs; sternopleura besides the one strong bristle with numerous small hairs.

Wings brownish; costa, small and large eross-veins, and apices of the longitudinal veins distiuctly bordered with brown.

Abdomen yellowish ciuereous or totalls cinereous; hrpoprgium of the male brownish-yellow, ratber small.

Legs yellow, somewlat infuseated; all the tibire witl a brown band at the distal end, and the hind tibiæ with an additional one near the base, these rings when feebly developed sometimes appearing as spots on the outer side; last two joints of the tarsi black; pulvilli white and rather eonspicuous.

Three females, one male. U.S. N. M. : Las Vegas, N. M., Aug. 13 th and 14th (H. S. Barber), labeled Helomyza tincta Walk. Aldrich: Custer, So. Dakota. Cooley: Missoula, Montana, May 28th.

The type is a male from Las Vegas, and will be returned to the National Museum.

\section{SPECIES NOT IDENTIFIED.}

\section{Itelomyzan apiealis Loew.}

"Yellow, the transverse veins and the apices of the longitudinal ones distinctly bordered with brown, upper balf of the pleura [mesopleura] with some scattered minnte pile, antennal arista with short pubescence.

"Yellow, opaque, the color of the thorax and scutellum verging more into latericious. Front brighter yellow. Antennæ almost fulvous, the third joint ovate, arista with short pubescence. Eyes rather large, roundish; the elueelis of medium widtlı; one vibrissa on each side, of medium size. Dorsum of the thorax sprinkled with very minute brown dots, the bristles of the median part surrounded at base with brownish dots a little larger. Scntellum bare exeept at the sides. Pleura with a faint stripe, the upper half hearing some minute pile. Hind margin of each abdominal segment bordered with blackish. Legs lutescent, the apices of the hind femora and bases of all the tarsi brownish, apices of the tibiæ brown, talsi black at tip. Wings cinereous-byaline, transverse veins and apices of the longitndinal ones distinctiy bordered with brown, costal bristles of medium size.-(District Columbia; Osten Sacken)."

Translation of original description.

Helomyza tineta Walker. Female.

"Body ferrugineous, clothed with short, black hairs; head and ehest beset with a few black bristles; head with a loasy tinge behind; sides of the face without bristles; epistoma not prominent; eyes pitchy; faeets small; sncker pitehy, clothed with tawny bairs; palpi tawns, beset with black bristles; feelers tawny at base; abdomen linear, pitchr, a little narower and very much longer than the ehest, tawny at the base, tapering towad the tip, which is also tawny; legs pale ferrugineons, clothed with short black hairs; tips of the shanks beset with black bristles; claws black, ferrugineous at the base; font-cushions pale tawny; wings gray, tawny for some breadth beneath the fore border and anong the veins in the disk; wing-ribs and veins tawng; longitudinal veins straight; 
middle cross-vein straight, upright; lower cross-vein straight, rery slightly oblique, parted by more than twice its length from the middle cross-vein, by thrice its length from the end of the fourth iongitudinal vein, and hy mear haif its length from the end of the fifth longitudinal vein; poisers tawny; scales sellow, very small.

"Length of the body 33 lines; of the wings $6 \frac{1}{2}$ lines.

"Nova Scotia. From Lient. Redman's collection."

\section{Helomyza fusciata Waiker.}

"Body clothed with black hairs and bristles; head gray, adorned wilh white reflections on each side of the erown and on the fore part, which is tawny; sides of the face without bristles; epistoma not prominent; eyes red, convex; all the facets very small; sucker black, clothed with tawuy hairs; feelers black, nearly as long as the fuce: third joint slightly conical, rather deep, Jonnded at the tip. very much longer than the second joint; first and secoud joints dark ferrugineous; bristle bare, rather stout at the base, more than twice the length of the third joint; chest and hreast gray ; chest with a tawny tinge; shoulders ferrugineous, breast more hoars; abdomen tuwns, slining, spindle-shaped, a little longer than the chest, slender at the tip; sntures of the segments black; legs tawus, clothed with hlack hairs and bristles; feet black, tawus at the base; foot-cushions very small; wings pale gray, with a very slight tawn tinge; wingribs pale tawny; veins pitchy, pale tawny toward the base; lower cross-vein parted by much less than twice its length from the middle cross-vein, having twu very indistinct curves, the lower outward, the upper inward; scales very small. whitish, with pale yellow horders; poisers taw $y$.

"Length of body 2 lines, wings 4 lines.

"Nova Scotia. Lieut. Redman's collection."

The two descriptions immediately preceding, by Walker, neer not give the student much trouble. They are inserted merely for completeness, and to satisfy any curiosity which might arise, but not with the expectation that they will be identified. In fact, one would almost certainly go wrong in identifying a species under either name, no matter how well the description fit. Czerny (op. cit., pp. 202-205) has reported the results of his examination of Walker's types of Helomyzidæ; out of 36 cases examined, there was not one that even belongs in this family, the types being mostly Sapronyzidx, with an admixture of Trypetide, Anthomyida, ete. However, he does not say anything about tincta, and reports fasciatu lacking in the Museum. Hence we have not even the satisfaction of positively exclurling them from the family.

Two specimens of barberi were received from the U. S. National Musemm moder the name tincta $W$ alker, but it is probable that the name was applied before Czemy published his results; at any rate we do not accept it. 
Melomyza iniens Giglio-Tos.

"Yellowish-testaceous; the face pale yellow, third antenual joint almost circular, black at base and on the upper margin; arista long, plumose; thorax ochraceous, dotted with brown; pleura pale sellow; scutelium ochraceous, with two brown vittæ and four bristles; abdominal segments bordered with brown behind; legs in the male stout and bairy; bases and apices of the tibie annulate with black; tarsi black at apex; wings yellowish, costa with spinules, the front margin, transverse veins and apex of the fourth longitudinal veiu brown. Length 9 mm."

Translation of original description. The type locality was sinply Mexico. In his later description Giglio-'Tos adds that there is a black spot each side of the ocellar spot; plumosity of the arista medium; pleura with a brownish stripe; all the femora with an apical brown spot above; hind tibix with a black ring near the base; apices of all the tibixe and last four joints of all the tarsi black.

Van der Wulp, in his Biologia reference, calls attention to a few points. The most striking character is the infuscation upon the hind cross vein, which extends both ways along the fourth vein, so as to make a T-shaped mark. The original description does not correctly describe the apex of the wing; it is infuscated to the tip of the fourth vein. $V$ an der $W^{T}$ nlp had numerous specimens from Guerrero, a State of Southern Mexico.

Helomyza punctulata Van der Wulp.

"Testaceous; head and legs rufous; frout aud face witl black dots; wings blackish at the costa and tip.

"Length $5 \mathrm{~mm}$.

"Front broader than the eyes, orange-rufous; face, cheeks and occiput pale rufous; ocellar knob black; two black dots near the vertex next the eyes and two smaller ones between the eyes and the root of the anteuna; three similar points on the face-one in the middle and two on the sides of the oral margin, these latter bearing the vibrisse; face with a uarrow silver-white lateral margin; on the occiput is a centrul black spot, on each side with a white border. Antennæ rufous; third joint ovate; arista black, distiuctly plumose. Proboseis pale rufous; palpi black, at least at the tip. Thorax and scntellum reddish testaceous; thoracic dorsum with more or less distinct brown stripes; a blackish band from the shoulders to below the base of the wings; pleure and metanotum pale rufous; thorax laterally with several bristles; scutellnm with four bristles. Abdomen rufous, the segments with blackish hind borders and marginal bristles. Legs pale rufous, the tarsi towards the end and the tip of the bind femora blackish; femora and tibire with weak bristles. Halteres rufous. Wings with short spines along the costa; from the end of the first vein the costa has a blackish border, which becomes broader outwards and extends round the tip of the wing; the cross-veins are covered by blackish spots; venation as in the preceding species [iniens].

"Habitat. Mexico, Omilteme in Guerrero, $8000 \mathrm{ft.}$ (H. H. Smith)." 
Melomyza distigua Van der Wulp:

"Rufo-testaceous; antenne and legs rufous; tro rounded spots in the first posterior cell, in addition to the other blackish markings on the wings.

"Length 5-7 mm.

" Mule.-Head pale rufous; front much broader than the eyes; ocellar point shining brown, emitting two bristles, which are curved forward; exterior to these are two other bristles, and on each side of the vertex a pair of post-rertical bristles; face and cheeks broad; two neak vibrissæ at the oral nargin. Antennce rufous, short; third joint rounded ; arista black, nearly bare. Proboscis and palpi rufons. Thorax and scutellum testaceous; thoracic dorsum with numerous bair-points; plenræ with a brown stripe from the shonlders to beneath the base of the wings; the sirles of the thorax with some bristles; scutellum with four bristles-one on each side and two at the hind margin; metanotum rufous. Abdomen grayish-brown, the aual segment globular and more rufous; the segments with some marginal and lateral bristles. Legs rufous, tips of the tibia. and the last three joints of the tarsi blackish; hind tibire with an indistinet brown ring near the base; femora rather robust, hairy beneath, the first and third pairs each with a row of bristles on the upper side; tibiæ with a preajical bristle. Halteres pale rufous. Wings grayish, with a row of short costal bristles, and with a blackish costal border, covering the mediastinal cell and from there extending to the tip of the wing, where it becomes narrower, to the end of the fourth vein; the cross-veins bordered with black; a spot on the fourth vein beyond the posterior cross-vein, a rounded dot between the second and third veins, just above the small cross-vein, and two similar spots between the third and fourth veins. Small cross-vein a little besond the end of the first vein and besoud the middle of the discal cell; posterior cross-vein straight and slightly oblique.

"Female.-Differs from the male in having the abdomen pointed towards the apex, the arista shortly plumose, and the legs more sleuder and less hairy: the femora have a brown spot on the upper side near the tip, and the tibix dark rings near the base; the markings of the wings are similar, only the blackish lot between the second and third veins is wanting.

"Hab. Mexico, Amula, $6000 \mathrm{ft}$. ; Xucumanatlan, $7000 \mathrm{ft}$.; and Sierra de las Aguas Escondidas, 9500 ft., all in Guerrero (H. H. Smith)."

Helomyza polystigua Van der Wulp.

"Testaceous; a blackish stripe on the pleuræ; wings with a blackish border tw the costa and to the cross-veins, and numerous spots in all the rells. Length $1.5 \mathrm{~mm}$.

"Allied to the preceding species [tistigma], but smaller and differing from it in the markings of the wings. Face, cheeks, and anterior portion of the front yellowish, with a white reflection; front posteriorly rufous, with some brown points; frontal bristles as in $H$. distigma; a black spot on each side betwcen the orbits and the ront of the antenna. Antennze rufous; third joint rounded. blackish on the upper side; arista with very short hairs. Proboscis rufous (the palpi inconspicuous in the specimens examined). Thorax and scutellum brown. ish testaceous, the shoulders jellowish, beneath them on the partly ciuereous pleure a blackish stripe; scutellum with four bristles. Abdomen brown, the segments with narrow black borders. Femora blackislı; tibia rufuus, with black

TRANS, AM, ENT, SOC, $\mathrm{XXXIV}$.

M A RCH, 190 s 
tips; first joint of the tarsi rufons, the following joints blackish; tibise with a preapical bristle. Halteres rellow. Wings grayish; a black border along the costa, aroumd the tip and on the cross-veins, and hlackish spots of different sizes in all the cells; the costa with a row of short bristles; small cross-vein nearly nnder the end of the first vein, and on the middle of the discal cell.

"Hab. Mexico, Sierra de las Aguas Escondidas in Guerrero, 9500 ft. (H. H. Suith).

"Two female specimens."

\section{ALIOPII YLA Loew.}

One fronto-orbital bristle; five dorso-central, arranged as in Helomyza; one humeral; one propleural ; one presutural ; two notoplenral; no prescutellar; two pairs scutellar; three supra alar; one sternopleural; no mesopleural.

Hear as in Helomyzu, third antennal joint a little elongated, arista pubescent.

The main distinction between this genus and Helomyza is in the absence of the humeral bristle in the latter.

Only one North American species bas been brought to light.

Allopyla laevis Loew.

Length $4.7 \mathrm{~mm}$.; of wing $5 \mathrm{~mm}$.

Yellow, antenna of the same color or a little darker, third joint infuscated in the female; arista pilose.

Head yellow; front saffron-yellow, with vers delicate puhescence, eres rather large (about twice the width of the cheeks), ronnd; cheeks straw-yellow; vibrissæ very delicate.

Thorax varying from saffron to straw-yellow, densely pubescent; scutellum bare exeept the ordinary four bristies; mesopleura bare; sternoplenra rather sparsely pubescent, with one strong bristle.

Abdomen yellow, more or less infuscated, hypopygium of the male small.

Wings almost hyaline, unspotted, except a little infuscation around the hind cross-vein.

Legs straw-yellow, last tarsal joint black.

Two nules and six females. Johnson: Montpelier, Vermont, June 25th; St. Johnsbury, Vermont, June 27th; Mt. Greylock, Massachusetts, June 15th ; Castle Rock, Pennsylvania, June 16th. U. S. N. M.: White Mountains, New Hampshire, Morrison. Mldrich: Guenes Island, Washington, July 13th; Mt. Constitution, Orcas Island, Washington, July 7 th.

sIIIGO Aldrich, n. gen. = $=3$ ayouia

(Latin, siligo a very pale kind of wheat; feninine, accent on sec. ond sylable.)

One humeral hristle; one propleural; two notopleural ; five dorso- 
central ; one presutural; three supra-alar; two scutellar (pairs); one mesosternal; two fronto orbital ; two stemopleural ; no prescutellar.

Head rounded, eyes round; antenna short, third joint slightly elongated, with short, bare arista; face molerately receding, epistoma ascending between the small vibrisse, with a distinct edge. Thorax with sparse and coarse hairs, besiles the bristles. Wings with first vein short, and the anxiliary pale and thin, difficult to perceive, yet ending separate from the first vein.

Type.-Oregona.

On account of the comparative shortness and indistinctness of the auxiliary vein, it may be thought that siligo is not a true Helomyzid genus; after comparing it with numerous genera in Sapromyzida, Geomyzida, etc., we are satisfied that its nearest relationships are here. It is very unlike Curtonotum.

While the conrse of the suture over the middle of the dorsum is not very apparent, either in this or Helomyza, the indications are that in Helomyza there is only one bristle before the suture, while here there are two, and only three behind.

TABLE OF SPECIES.

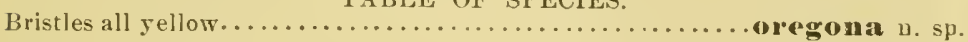

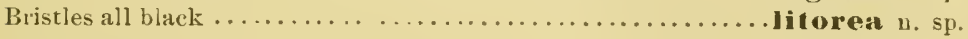

Siligo oregona Aldrich, n, sp., Pl. IV, figs. 1, 7.

Length $2.8 \mathrm{~mm}$; of wing, the same.

Yellow. All the hails and bristles yellow, except the spines of the costa, which are black.

Head entirely sellow; eyes of medium size, round; antenna sellow; arista of medium size, ouly microscopically pubescent; ocellar bristles very loug; cheeks somewhat inflated, about the width of the ese.

Thorax entirely straw yellow, dorsum sparsels pubescent; scutelium entirels gellow, bare except the ordiuary four bristles; mesopleura bare except one las'ge and two small sellow bristles at the upper posterior corner; propleura bare except the one propleural bristle; sternopleura besides the two long bristles on the upper edge with rather sparse pubescence.

Abdomen grayish-rellow, hrpopygium of the male small and inconspicuous, but armed with a slender black filanent turuing back.

Wings hyaline, veins yellow; spines of the costa black, rather long and promiuent.

Legs entirely straw-yellow; a row of rather strong bristles on the under side of the fore femur; tarsal claws black except at base.

Three males, two females. Aldrich: Hood River, Oregon, July.

The head in oregona is more produced downwarl than in litorea, but the difference is almost wholly in the cheeks; in oregonu the epistoma extends upward between the vibrisse farther than in litorea.

TRANS. AM. ENT. SOC, XXXIV.

M A RCH, 1908. 
Silizo litorea Aldrich, n. sp.

Length $1.9 \mathrm{~mm}$.; of wing, about the same.

Ground color of body black, bristles all black.

Head yellow, the occiput, vertex and middle of face black; epistoma bordered with a narrow black line, which expands upward hetween the vibrissal ridges; vibrisse of moderate size; antenu sellow, the third joint considerably infuscated and slightly elongate; arista short, hack, a little thickened at hase; front yellow, the sides narrowiy cinereous and the vertex black in color, which does not extend forward in a sharp angle as usual; two large fronto-orbital bristlesbut the posterior one missing on one side in the described specimen, seemingly au abnormality. Eyes ronndish, slightly angulated above, the cheeks over onethird as high as the eyes. Palpi rather brownish-yellow.

Thorax cinereous, with black ground color, the pleuræ, scutellum and metanotum concolorous; bristles large and hairs very few; between the rows of dorso-centrals are about ten hairs arranged in two rows, vers distinct; scutellum with two pairs of bristles, otherwise bare; mesoplenra with one bristle and several hairs at the posterior enge, just below the base of the wing; pteropleurn bare; sternoplenra with two bristles and a few hairs; halteres light yellow.

Abdomen cinereous, concolorous with thorax; hypolygium small, with some indistinct grasping organs turned forward nuderneath.

Coxe and femora blackish, tibire and tarsi sellow, the latter but little infuseated towards the tip; pulvilli moderately large.

Wings almost hyaline, the veins yellowish, cross-veins not infuscated; third vein ending precisely in the apex; bristles of the costa small and few.

One male. Aldrich: Pacific Grove, California, May 8, 1906, collected at the seashore a little above high tide line, where a small seepage of fresh water made a streak of verdure.

\section{Explanation of Plate IV.}

The parts are variously magnified: No. 1 is one of the smallest of the family; No. 3 above the average. The veins of the wings are not generally very black in life, making the actual appearance quite different from the drawing; this is especially true of No. 7 .

Fig. 1.- Siligo oregonc, new geuus and species.

“2.-Porsenus johnsoni, new genus and species.

" 3.-Eccoptomeru americanu, new species.

"4.-Anorostoma maculata, new species.

" 5.- - norostoma maculata, new species.

"6.-Helomyza limbata, Thomson.

"7.-Siligo oregona, new genus and species.

" 8.-Cyrtonotum helvum, I,oew.

‘ 9.-Cyrtonotum helrum, Loew.

Figs. 8 and 9 are added for comparison, but the species does not belong to this family. The second basal cell is confluent with the discal, as figured, in many cases, but is sometimes distinct; the second and third basals are very small. The anterior fronto-orbital curves strongly forward. 


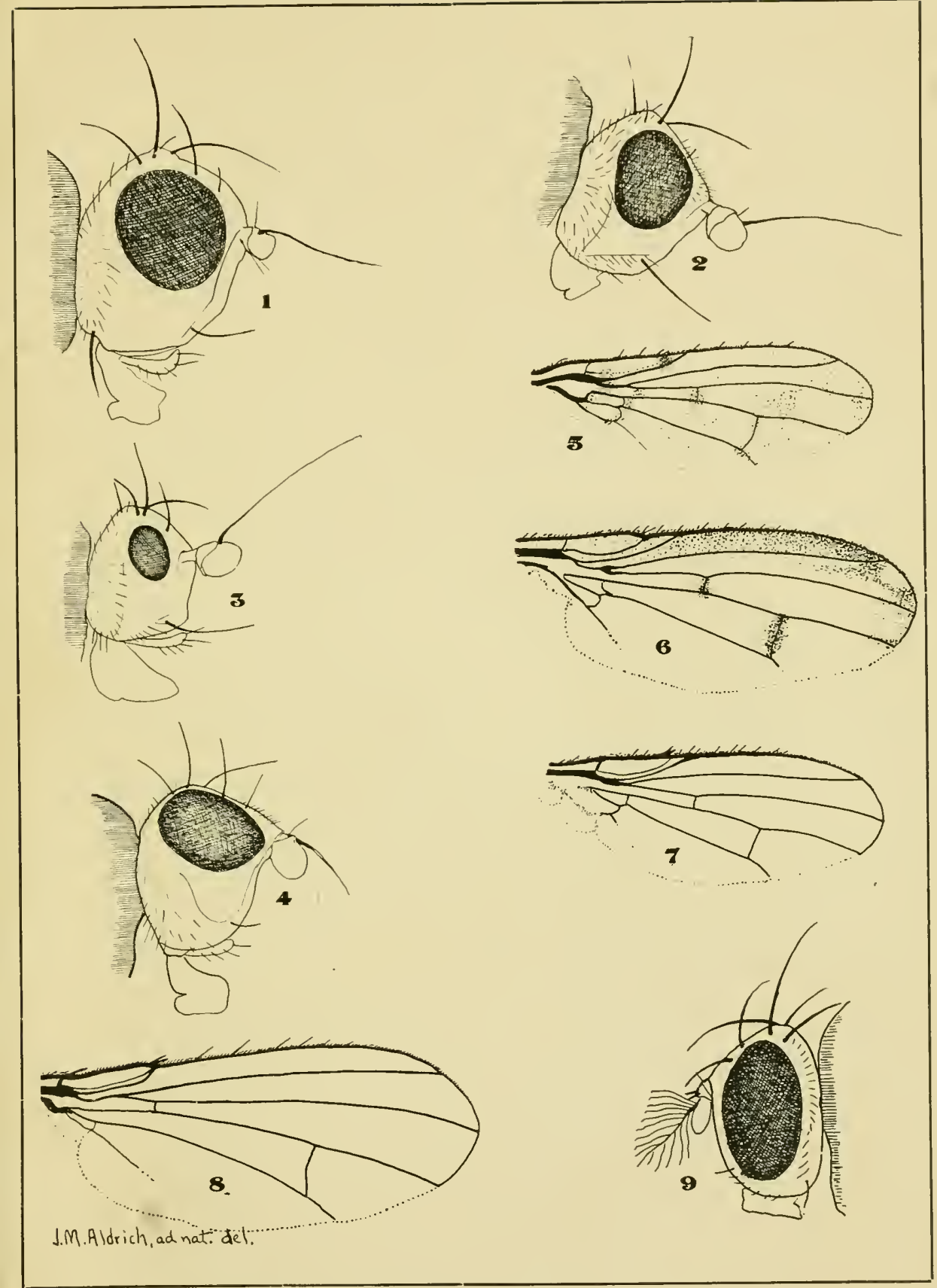

ALDRICH AND DARLINGTON ON DIPTERA. 




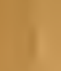



QL Aldrich, John Merton, 531 1866-1934.

A36 Papers on Diptera.

Ent.

QL

531

A36

Ent. 
SMITHSONIAN INSTITUTION LIBRARIES 